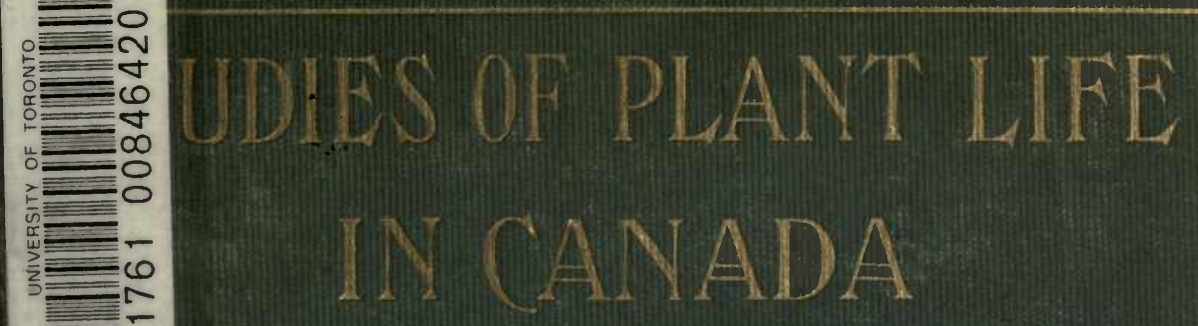

m

\title{
Handle with TREME CARE
} olume is damaged or brittle d CANNOT be repaired! ocopy only if necessary in to staff lot put in bookdrop ein Science Information Centre 





\section{STUDIES OF PLANT LIFE IN CANADA}





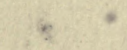

.

12 
PLATE I.

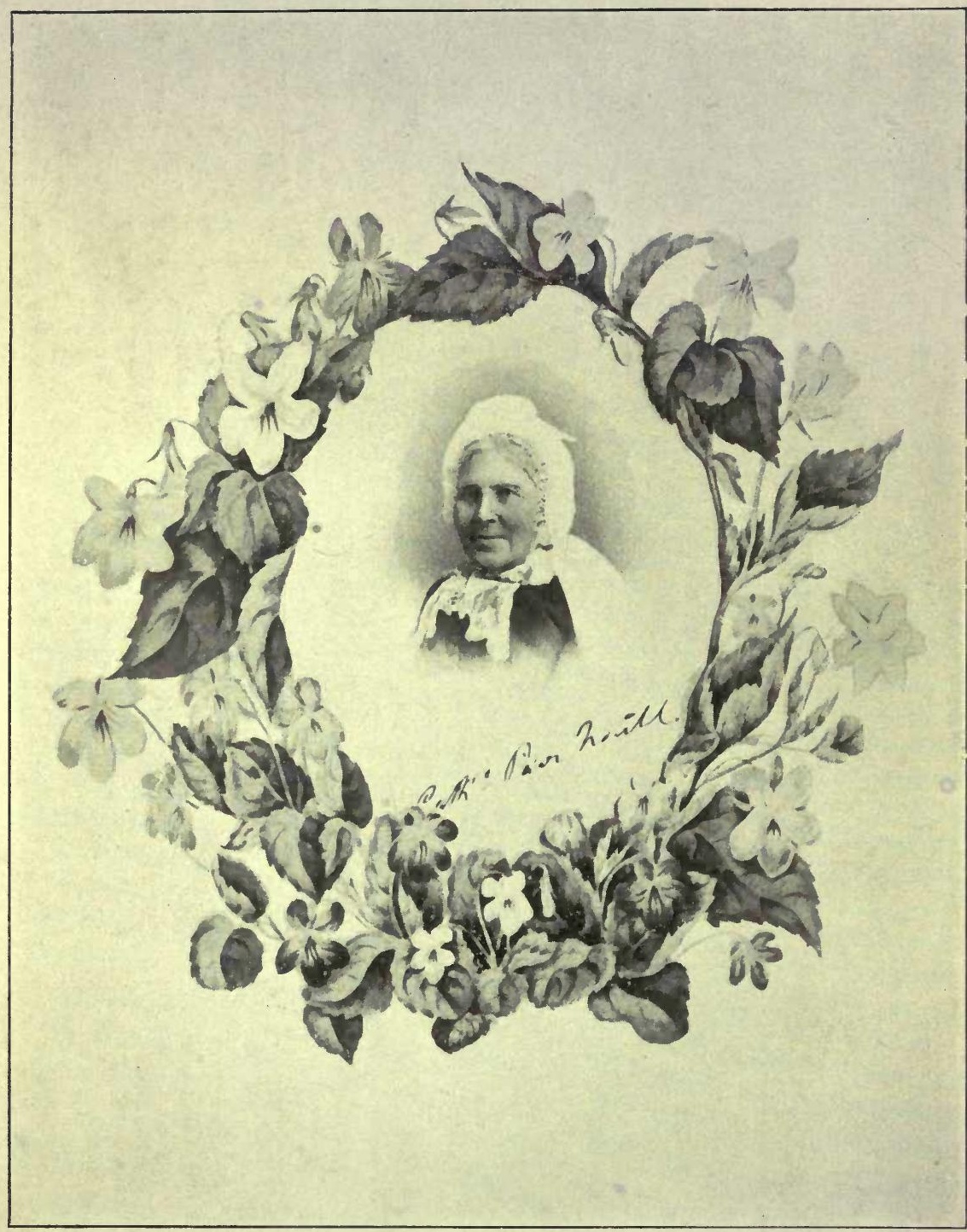

THE AUTHOR 
Entered according to Act of the Parliament of Canada, in the year one thousand nine hundred and six, by

Agnes D. Chamberlin,

at the Department of Agriculture. 
TO

HER EXCELLENCY

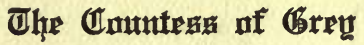

THIS BOOK IS BY HER KIND PERMISSION

RESPECTFULLY AND GRATEFULLY

DEDICATED 



\section{PREFACE}

THIs little work on the flowers and native plants of Central Canada is offered to the Canadian public, with the hope that it may prove a means of awakening a love for the natural productions of the country, and a desire to acquire more knowledge of its resources. It is not a book for the learned. The aim of the writer is simply to show the real pleasure that may be obtained from a habit of observing what is offered to the eye of the traveller, - whether by the wayside path, among the trees of the forest, in the fields, or on the shores of lake and river. Even to know the common name of a flower or fern is something added to our stock of knowledge, and inclines us to wish to know something beyond the mere name. Curiosity is awakened, and from this first step we go on to seek for higher knowledge, which may be found in works of a class far above what the writer of the present book can aspire to offer to the reader. The writer has adopted a familiar style in her descriptions of the plants, thinking it might prove more useful and interesting to the general reader, especially to the young, and thus find a place: on the book-shelves of many who would only regard it for the sake of its being a pretty, attractive volume, on account of the illustrations. These, indeed, are contributed by the pencil of a gifted and accomplished lady, Mrs. Agnes 
Chamberlin, a beloved relative, to whose artistic taste and talents the author is greatly indebted. She is conscious that many imperfections will be found in this volume, the contents of which have been written at intervals during a long series of years, many of which were marked by trials such as fell to the lot of the early colonists and backwoods settlers, and others of a more afflicting nature, which required patience and faith to bear and to say, "Thy will be done, O Lord."

There is a common little weed that is known by the familiar name of Carpetweed, a small Polygonum, that grows at our doors and often troubles us to root up, from its persevering habits and wiry roots. It is crushed by the foot and bruised, but springs up again as if unharmed beneath our tread, and flourishes under all circumstances, however adverse. This little plant had lessons to teach me, and gave courage when trials pressed hard upon me. The simplest weed may thus give strength if we use the lesson rightly and look up to Him who has pointed us to that love which has, clothed the grass of the field and cared for the preservation of even the lowliest of the herbs and weeds. Will He not also care for the creature made in His own image? Such are the teachings which Christ gave when on earth. Such teachings are still taught by the flowers of the field.

Mothers of Canada, teach your children to know and love the wild flowers springing in their path, to love the soil in which God's hand has planted them, and in all their after wanderings through the world their hearts will turn back with loving reverence to the land of their birth, to that dear 


\section{PREFACE}

country, endeared to them by the remembrance of the wild flowers which they plucked in the happy days of childhood.

As civilization extends through the Dominion and the cultivation of the tracts of forest land and prairie destroys the native trees and the plants that are sheltered by them, many of our beautiful wild flowers, shrubs and ferns will, in the course of time, disappear from the face of the earth and be forgotten. It seems a pity that no record of their beauties and uses should be preserved; and as there is no national botanical garden in Canada where collections of the most remarkable of our native plants might be cultivated and rescued from oblivion, any addition to the natural history of the country that supplies this want is therefore not without its value to the literature and advancement of the country, and it is hoped that it may prove valuable to the incoming immigrant who makes Canada an abiding home.

The author takes this opportunity of acknowledging the kind and invaluable assistance which she has received from her friend, Mr. James Fletcher, of the Dominion Library, and the encouragement to her labors by Professor Macoun's opinion of the usefulness of her work on the vegetable productions of the country. She has also to acknowledge the benefit derived from the pamphlet on the "Canadian Forest Trees," by her respected friend, Dr. Hurlburt. Mr. Fletcher, with that zeal for his favorite study which has already won for him so high a place among the naturalists of Canada, and that kindness which shrinks from no trouble and has won him so many friends, accepted the drudgery of revising the work and seeing it through the press. 


\section{STUDIES OF PLANT LIFE}

The Wild or Native Flowers and Flowering Shrubs are arranged, as a general rule, in the order of time in which they appear in the woods; but it has been thought that by grouping them somewhat in families, especially where only a short mention is made of some species, it would be easier to refer to them than if this order were strictly adhered to.

C. P. T.

LAKEFIELD, 1885. 


\section{LIST OF ILLUSTRATIONS}

Plate I. Frontispiece.

Portrait of the Author.

Plate II. P. 8.

Wood Anemone (Anemone Nemorosa).

Sharp-lobed Hepatica (Hepatica acutiloba).

Spring Beauty (Claytonia Virginica).

Large-flowered Bellwort (Uvularia grandiflora).

Plate III. P. 18.

Large White Trillium (Trillium grandiflorum).

Rock Columbine (Aquilegia Canadensis).

Yellow Adder's Tongue (Erythronium Americanum).

Plate IV. P. 24.

Blood Root (Sanguinaria Canadensis).

Blue Cohosh (Caulophyllum thalictroides).

Puate V. P. 30.

Marsh Marigold (Caltha palustris).

Wild Lupine (Lupinus perennis).

Plate VI. P. 36.

Wood Geranium (Geranium maculatum).

Purple Trillium (Trillium erectum).

Squirrel Corn (Dicentra Canadensis).

Star Flower (Trientalis Americana).

Plate VII. P. 48 ,

Scarlet Painted Cup (Castilleia coccinea).

Showy Orchis (Orchis spectabilis).

Indian Turnip (Arisæma triphyllum).

Coneflower (Rudbeckia hirta).

Plate VIII. P. 56.

False Mitrewort (Tiarella cordifolia).

May-apple (Podophyllum peltaturn). 


\section{STUDIES OF PLANT LIFE}

Plate IX. P. 66.

Painted Trillium (Trillium erythrocarpum).

Wild Lily of the Valley (Smilacina bifolia).

Flowering Wintergreen (Polygala paucifolia).

Plate X. P. 76.

Arrow-head (Sagittaria variabilis).

Great Lobelia (Lobelia syphilitica).

Cardinal Flower (Lobelia cardinalis).

Plate XI. P. 84.

Four-leaved Loose-Strife (Lysimachia quadrifolia).

Marsh Vetchling (Lathyrus palustris).

Plate XII. P. 96.

False Fox-glove (Gerardia quercifolia).

Turtle-head (Chelone glabra).

Dragon-head (Physostigia Virginiana).

Plate XIII. P. 120.

Showy Lady's Slipper (Cypripedium spectabile).

Harebell (Campanula rotundifolia).

Wild Orange Lily (Lilium Philadelphicum).

Plate XIV. P. 144.

Pitcher Plant (Sarracenia purpurea.)

Plate XV. P. 160.

Sweet-Scented Water-Lily (Nymphæa odorata).

Yellow Pond Lily (Nuphar advena).

Plate XVI. P. 172.

Daphne Mezereum.

Plate XVII. P. 184.

American Brooklime (Veronica Americana).

Purple Scented Raspberry (Rubus odoratus).

One-flowered Pyrola (Moneses uniflora).

Shin-leaf (Pyrola elliptica).

Plate XVIII. P. 192.

Trailing Arbutus (Epigæa repens).

Plate XIX. P. 200.

Straw berry Blite (Blitum capitatum).

Plate XX. P. 208.

Early Wild Rose (Rosa blanda).

Beard Tongue (Pentstemon pubescens). 


\section{INTRODUCTION}

“ There's nothing left to chance below ;

The Great Eternal cause

Has made all beauteous order flow

From settled laws."

Every plant, flower, and tree has a simple history of its own, not without its interest if we would read it aright. It forms a page in the great volume of Nature which lies open before us, and without it there would be a blank; in Nature there is no space left unoccupied.

We watch on some breezy day in summer one of the winged seeds of the thistle or dandelion taking its flight upward and onward, and we know not where it will alight, and we see not the wisdom of Him

"Who whirls the blowballs' new-fledged pride

In mazy rings on high,

Whose downy pinions once untied

Must onward fly.

" Each is commissioned, could we trace

The voyage to each decreed,

To convey to some barren place

A pilgrim seed."

-Agnes Strickland.

When the writer of the little volume now offered to the Canadian public first settled in the then unbroken backwoods on the borders of the Katchewanook, just where the upper waters of a chain of lakes narrow into the rapids of the wildly beautiful Otonabee, that section of the province 
was an unbroken wilderness. There was no road opened, even for the rudest vehicle, on the Douro side of the lakes, and to gain her new home the authoress had to cross the river at Auburn, travel through the newly cut road in the opposite township, and again cross over the Otonabee at the head of the rapids in a birch-bark canoe. There was at that period no other mode of connection with the northern part of the Township of Douro. Now a branch railroad from Peterboro' terminates in the flourishing village where once the writer wandered among the forest pines looking for wild flowers and ferns.

As to the roads, one might say, with the Highland traveller,

" Had you but seen these roads before they were made, You'd have lift up your hands and have blessed General Wade."

The only habitations, beyond our own $\log$ cabin, at the date of which I write, were one shanty and the log house of a dear, lamented and valued brother, the enterprising pioneer and founder of the prosperous village of Lakefield.

It may easily be imagined that there were few objects of interest in the woods at that distant period of time-1832or as a poor Irish woman sorrowfully remarked, "Tis a lonesome place for the likes of us poor women folk; sure there isn't a hap'orth worth the looking at; there is no. nothing, and it's hard to get the bit and the sup to ate and to drink."

Well, I was better off than poor Biddy Fagan, for I soon found beauties in my woodland wanderings, in the unknown trees and plants of the forest. These things became a great resource, and every flower and shrub and forest tree awakened an interest in my mind, so that I began to. 
thirst for a more intimate knowledge of them. They became like dear friends, soothing and cheering, by their sweet unconscious influence, hours of loneliness and hours of sorrow and suffering.

Having never made botany a study, and having no one to guide and assist me, it was acquiring knowledge under difficulties, by observation only; but the eye and the ear are good teachers, and memory is a great storehouse, in which are laid up things new and old which may be drawn out for use in after years. It is a book the leaves of which can be turned over and read from childhood to old age without weariness.

Having experienced the need of some familiar work giving the information respecting the names and habits and uses of the native plants, I early conceived the idea of turning the little knowledge which I gleaned from time to time to supplying a book which I had felt the great want of myself; but I hesitated to enter the field when all I had gathered had been from merely studying the subject without any regular systematic knowledge of botany. The only book that I had access to was an old edition of "North American Flora," by that industrious and interesting botanist, Frederick Pursh. This work was lent to me by a friend, the only person I knew who had paid any attention to botany as a study, and to whom I was deeply indebted for many hints and for the cheering interest that she always took in my writings, herself possessing the advantages of a highly cultivated mind, educated and trained in the society of persons of scientific and literary notoriety in the Old Country. Mrs. Stewart was a member of the celebrated Edgeworth family. Pursh's "Flora," unfortunately for me, was written chiefly in 
Latin. This was a drawback in acquiring the information I required; however, I did manage to make some use of the book, and when I came to a standstill I had recourse to my husband, and there being a glossary of the common names, as well as one of the botanical, I contrived to get a familiar knowledge of both.

My next teachers were old settlers' wives, and choppers and Indians. These gave me knowledge of another kind, and so by slow steps, and under many difficulties, I gleaned my plant-lore. Having, as I have said, no resource in botanical works on our native flora, save what I could glean from Pursh, I was compelled to rely almost entirely upon my own powers of observation. This did much to enhance my interest in my adopted country and add to my pleasure as a relief, at times, from the home-longings that always arise in the heart of the exile, especially when the sweet opening days of Spring recall to the memory of the immigrant Canadian settler old familiar scenes, when the hedges put out their green buds, and the Violets scent the air; when pale Primroses and the gay starry Celandine gladden the eye, and the little green lanes and wood-paths are so pleasant to ramble through among the Daisies and Bluebells and Buttercups; when all the gay embroidery of English meads and hedgerows put on their bright array. But for the Canadian forest flowers and trees and shrubs, and the lovely ferns and mosses, I think I should not have been as contented as I have been away from dear old England. It was in the hope of leading other lonely hearts to enjoy the same pleasant recreation that $I$ have so often pointed out the natural beauties of this country to their attention, and now present my forest gleanings to them in a simple form, trusting that it may not prove an unacceptable 
addition to the literature of Canada, and that it may become a household book, as Gilbert White's Natural History of Selborne is to this day among English readers. And now at the age of eighty-three years, fifty-two of which have been spent in the fair province of Ontario, in her far forest home on the banks of the rapid Otonabee, the writer lays down her pen, with earnest prayers for the prosperity of this her much beloved adopted country, that with the favor and blessing of our God it may become the glory of all lands.

LAKEFIELD, ONT, 1884.

\section{ACKNOWLEDGMENT}

Mrs. Chamberlin gratefully acknowledges the advice and encouragement given to her in the preparation of this work by the Dominion Botanist, Professor John Macoun, F.C.S., F.R.S.C., and by the Assistant Botanist, James M. Macoun, C.M.G.; and also gladly embraces the opportunity afforded in this preface of extending her sincere thanks to Dr. James Fletcher, the well-known entomologist and botanist, who in the midst of the pressing duties of his position was kind enough to undertake the correction of the proofs of this present edition of Plant Life in Canada.

Mrs. Chamberlin also makes grateful acknowledgment of the valuable assistance given her by her daughter, Mrs. Geraldine Moodie, in photographing the paintings from which the plates used in the present edition were taken.

LaKefield, ONT., August 1st, 1906. 



\section{STUDIES OF PLANT LIFE}

\section{SECTION I.}

\section{WILD, OR NATIVE FLOWERS}

\section{VIOLETS.}

"The violet in her greenwood bower

Where birchen boughs with hazel mingle, May boast herself the fairest flower

In forest, glade or copsewood dingle." $-S$ cott.

THERe is music and poetry in the very name-" Violet." In the forest wilderness, far removed from all our early home associations, the word will call up, unbidden, a host of sweet. memories of the old familiar land where as children we were wont to roam among bowery lanes, and to tread the well-worn pathways through green pastures down by the hawthorn hedge, and along grassy banks where grew in early spring Primroses, Bluebells, and purple Violets. What dainty, sweet-smelling posies have you and I, dear reader ( $I$ speak to the emigrants from the dear Old Country), gathered on sunny March and April days on those green banks and grassy meadows? How many a root full of freshly opened Violets or Primroses have we joyfully carried off to plant in our own little bits of garden ground, there to fade and wither beneath the glare of sunshine and drying winds. Little we heeded 


\section{STUDIES OF PLANT LIFE}

this, for the loss was soon replaced from Nature's abundant store.

I doubt not but that Violets and Primroses, the Bluebells and the Cowslips yet bloom and flourish in the loved haunts of our childhood. Year after year sees them bloom afresh-pure, sweet and fragrant as when last we filled our laps with their flowers or twined them in garlands for our hair; but we change and grow old. God wills it so, and it is well! Though Canada boasts of many members of this charming family, there is none among our Violets so deeply blue, or so deliciously fragrant, as the common English March Violet, Viola odorata. This sweet flower bears away the crown from all its fellows. One of our older poets (Sir Henry Wotton) has said, as if in scornful contrast of it when compared with the rose,

"Ye violets that first appear,

By your pure purple mantles known,

Like the proud virgins of the year,

As if the spring were all your own,

What are ye when the rose is blown?"

Good Sir Henry, we would match the perfume of the lowly violet even against the fragrance of the blushing rose.

Though deficient in the scent of the purple Violet of Europe, we have many lovely species among the native Violets of Canada. The earliest is the small flowered

\section{EARLY White VIOLET-Viola blanda (Willd.).}

This blossoms early in April, soon after the disappearance of the snow. The light green smooth leaves may be seen breaking through the black, damp, fibrous mould closely rolled inward at the margins; the flowers are small, rather sweet scented, greenish white, with delicate pencil- 
lings of purple at the base of the petals. It is a moistureloving plant, and affects open, recently overflowed ground, near creeks. It comes so early that we welcome its appearance thankfully, for it

"Tells us that winter, cold winter, is past,

And that spring, welcome spring, is returning at last."

On pulling up a thrifty plant late in the summer, it surprises you with a new set of flowers, quite different from the spring blossoms; these are small buds and flowers of a dull chocolate-brown, lying almost covered over in the mould, with seed pods, some ready to shed the ripened seed, others just formed.

A variety of this mysterious little plant has been distinguished by some botanists as Viola clandestina, from the curious hidden way in which it produces the subterranean flowers and seeds.

The commonest among our blue Violets is

\section{The Hooded Violet-Viola cucullata (Ait.),}

so-called from the involute habit of the leaves, which, when: first appearing, are folded inwardly, as if to shield thetender buds of the flowers from the chilling winds. There are many forms or varieties of this species, varying very much in appearance, the difference being probably due to" the habitat in which they occur. One of the handsomest is: the large blue Wood Violet, which flowers about the middle of June, has blue scentless flowers with round petals, and large blunt hirsute leaves, and is found in low woods.* Another variety, with deep violet flowers, has elongated petals and pointed, rather smooth leaves of a purplish tint,

*Viola Dicksoni, Greene. 


\section{STUDIES OF PLANT LIFE}

at least till late in the season. It is found on open sunny banks and dry grassy hill-sides. $\dot{\dagger}$ Yet another variety is often found by the sides of springs and rivers, forming spreading tufts among the grass with its smooth-pointed leaves and pale, delicate flowers. $\$$

The prettiest of all our blue Violets is the

\section{ARrow-Leaved VIoLet-Viola sagittata (Ait.).}

It is found in low, sandy, shady valleys or very light loamy soil. The leaves of this species are not always arrow or heart-shaped, but in some cases are long and narrow, blunt at the apex, decurrent on the short leaf-stalk, notched at the edges, and rather roughened and dulled in color by the short silvery hairs on the surface. The flowers rise singly from the crown of the plant; color, a bright royal blue, a little white at the base of the petals, which are bearded with soft silky wool; anthers, a bright orange color, and forming a tiny cone from the meeting of the tips. The flowers, six or eight in number, fall back from the centre and lie prostrate on the closely horizontal leaves. The unopened buds are sharply folded with bright green sepals, and are of a deep bluish-purple. Another form, sometimes called Viola ovata, very nearly resembles the above, but the leaves are less hairy and the color is more purple in the tint.

\section{The Pencilled Violet-Viola renifolia (Gray)}

bears its white blossoms on rather long slender foot-stalks, and these are slightly larger than those of the above. It is milky-white, with dark veinings. The leaves, although

+Viola subviscosa, Greene.

$¥$ Viola prionosepala, Greene. 


\section{NATIVE WILD FLOWERS}

covered with soft hairs, have a bright, smooth and shining appearance. They are round heart or kidney-shaped, notched at the edges. As the summer advances the foliage of the Pencilled Violet increases in luxuriance, and many white fibrous running roots are produced in the loose soil. This attractive species may be found in swamps and forests, growing amidst decayed wood and mosses, and increasing after the same manner as Viola blanda. A point which easily distinguishes this species from the last is the total absence of scent; the leaves, too, are much more pubescent -a character which is very noticeable in the early morning, when they are covered with dew.

Among the branching Violets we have two pretty lilac ones, the Long Spurred Violet (Viola rostrata) and the Dog Violet (Viola canina var. sylvestris). These pretty species are distinguished by the long spur, lilac-tinted petals, striped and veined with dark purple and branching stem. The next in point of interest is the

\section{Dow Yellow Violet-Viola pubescens (Ait.).}

This handsome species is confined to our forests and copses. It will attain to more than a foot in height in its rich native woods; it blossoms in spring, and quite often through the early summer; the color is golden yellow, veined with black jetty lines. The seed-vessels are deeply clothed with white silky wool.

The Yellow Violet has been immortalized by the sweet verses of that rare poet of nature, Cullen Byrant-almost every child is familiar with his stanzas on the Yellow Violet. There is another variety of this Violet, called var. scabriuscula, which is not so branching; it is of lower growth, the leaves darker, and the blossoms smaller but 
of a deeper golden color. This variety is found in drier, more open soil-the black veining more distinctly marked than in the downy Yellow Violet, and the seed-vessels smooth. They both improve under culture, having two sets of flowers during the season.

Among the white Violets none is so beautiful as the

\section{Branching White Wood Violet-Viola Canadensis (L.).}

This, our Canada Violet, is worthy of a place in our gardens. Not only is it a lovely flower, but it takes kindly to garden culture, preferring a shady place to the open sunshine. In its native haunts-the rich black vegetable mould of beech and maple woods -it rises to the height of from nine inches to a foot, throwing out slender leafybracted branches, with many buds and pure milk-white flowers. The petals are slightly clouded on the outside with purple; the buds are also dark, while the petals of the flower are veined with purple, and in some cases there is a shade of yellow in the centre of the flowers, though this is not seen so distinctly when under cultivation.

The plant continues to send forth blossoms all through the summer, and even late in the month of September when undisturbed. The seeds, ripening early, form new plants, which, sheltered by the parent stem, continue to increase, forming a compact ball of snow-white flowers. This has been the case in my own garden. If well watered and in suitable soil, this pretty branching violet may be taken from the woods even in full bloom, and will grow and continue to blossom freely, but must have shade and moisture and leaf-mould to ensure success to its healthy growth. The leaves are large, broad at the base, narrowing to a very slender point, and coarsely toothed. 


\section{NATIVE WILD FLOWERS}

The violet has ever been a favorite flower with the poets; from Shakespeare and Milton down to the present day we find mention of this. lovely flower scattered through their verses. Nor are the old Italian poets silent in its praise. Luigi de Gonzaga, in stanzas addressed to his lady-love (Maria Mancini), says:

"But only violets shall twine

Thy ebon tresses, lady mine."

Milton, in his sonnet to "Echo," speaks of the "violet .embroidered vale."

Here are lines to early violets, after the manner of the old English poet, Herrick:

Children of sweetest birth, Why do ye bend to earth Eyes in whose deepest blue

Lies hid the diamond dew?

Has not the early ray

Yet kissed those tears away

That fell with closing day?

Say, do ye fear to meet

The hail and driving sleet

Which gloomy winter stern

Flings from his snow-wreathed urn?

Or do ye fear the breeze,

So sadly sighing thro' the trees,

Will chill your fragrant flowers

'Ere April's silv'ry showers

Have visited your bowers?

Why came ye till the Cuckoo's voice

Bade hill and dale rejoice?

Till Philomel, with tender tone

Waking the echoes lone,

Bade woodland glades prolong

Her sweetly tuneful song?

Till Skylark blithe and Linnet grey,

From fallow brown and meadow gay,

Pour forth their jocund roundelay? 


\section{STUDIES OF PLANT LIFE}

Till Cowslips wan and Daisies pied

Broider the hillock's side, And opening Hawthorn buds are seen

Decking the hedge-row screen?

What though the Primrose, drest

In her pure modest vest,

Came rashly forth

To brave the biting North,

Did ye not see her fall

Straight 'neath his snowy pall?

And heard ye not the West Wind sigh

Her requiem as he hurried by?

Go hide ye, then, till groves are green

And April's clouded bow is seen,

Till suns are bright, and skies are clear,

And every flower that doth appear

Proclaims the birthday of the year.

-C.P.T.

LIVER-LEAF-WIND-FLOWER-Hepatica acutiloba (DC.).

(PLATE II.)

" Lodged in sunny clefts,

Where the cold breeze comes not, blooms alone

The little Wind-flower, ${ }^{*}$ whose just opened eye

Is blue as the spring heaven it gazes at."

-Bryant.

The American poet Bryant has many happy allusions to the Hepatica under the name of "Wind-flower." The more common name among our Canadian settlers is "Snowflower," it being the first blossom that appears directly after the melting of the winter snows.

In the forest-in open, grassy woods, on banks and upturned roots of trees-this sweet flower gladdens the eye with its cheerful starry blossoms; every child knows it and fills its hands and pinafore with its flowers-pink, blue, deep azure and pure white. What the daisy is to England

- The blue-flowered Hepatica triloba is evidently the flower meant by the poet. 
PLATE 11.

1. Wood Anemone (Anemone Nemorosa). P. 20.

2. Sharp-lobed Hepatica (Hepat ca acutiloba). P. 8.

3. Spring Beauty (Claytonia Virginica). P, 24.

4. Large-flowered Bellwort (Uvularia grandiflora). P. 32. 


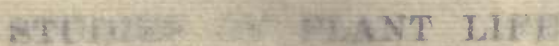

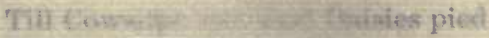

Becider the

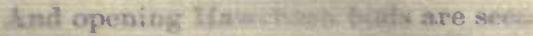

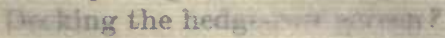

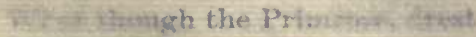

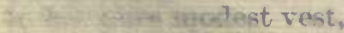

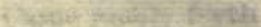

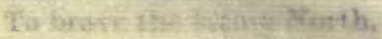

Did ye not and teer thats

Straight 'neath his mothy paefif

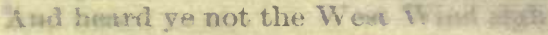

if ex renciciens as he hurried by?

Go hithe ye, then, till groves are green

And April's clouded bow is seeti,

Till suns are bright, and skies are clear,

And every flower that doth appear

Proclaims the birthday of the year.

-C.P.T.

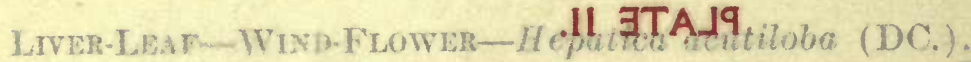

.0S .9 (orovomah 9nomsnA) snomsnA booW .I

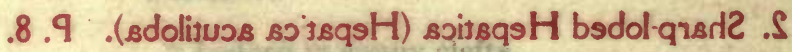

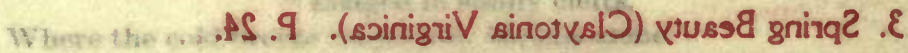

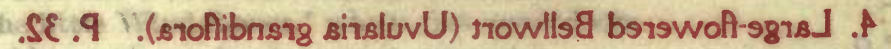

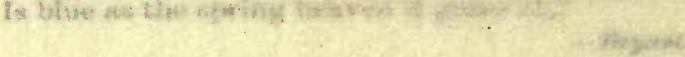

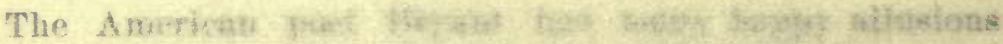

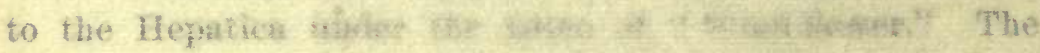

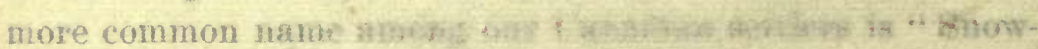

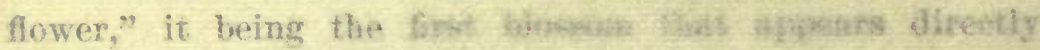
after the melting of the wintic sthistis

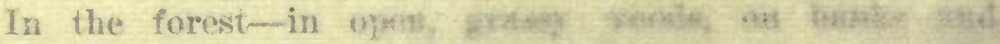

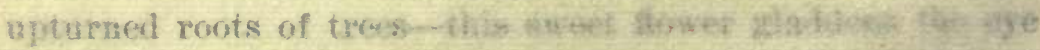

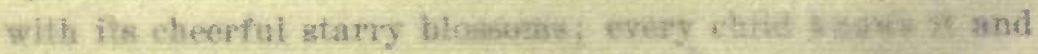

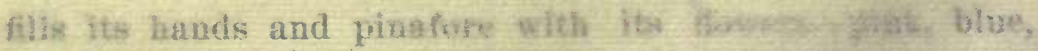
deep azure and pure white. What the it ay fin tos England

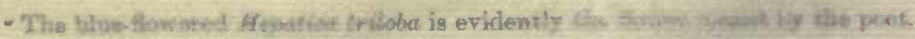




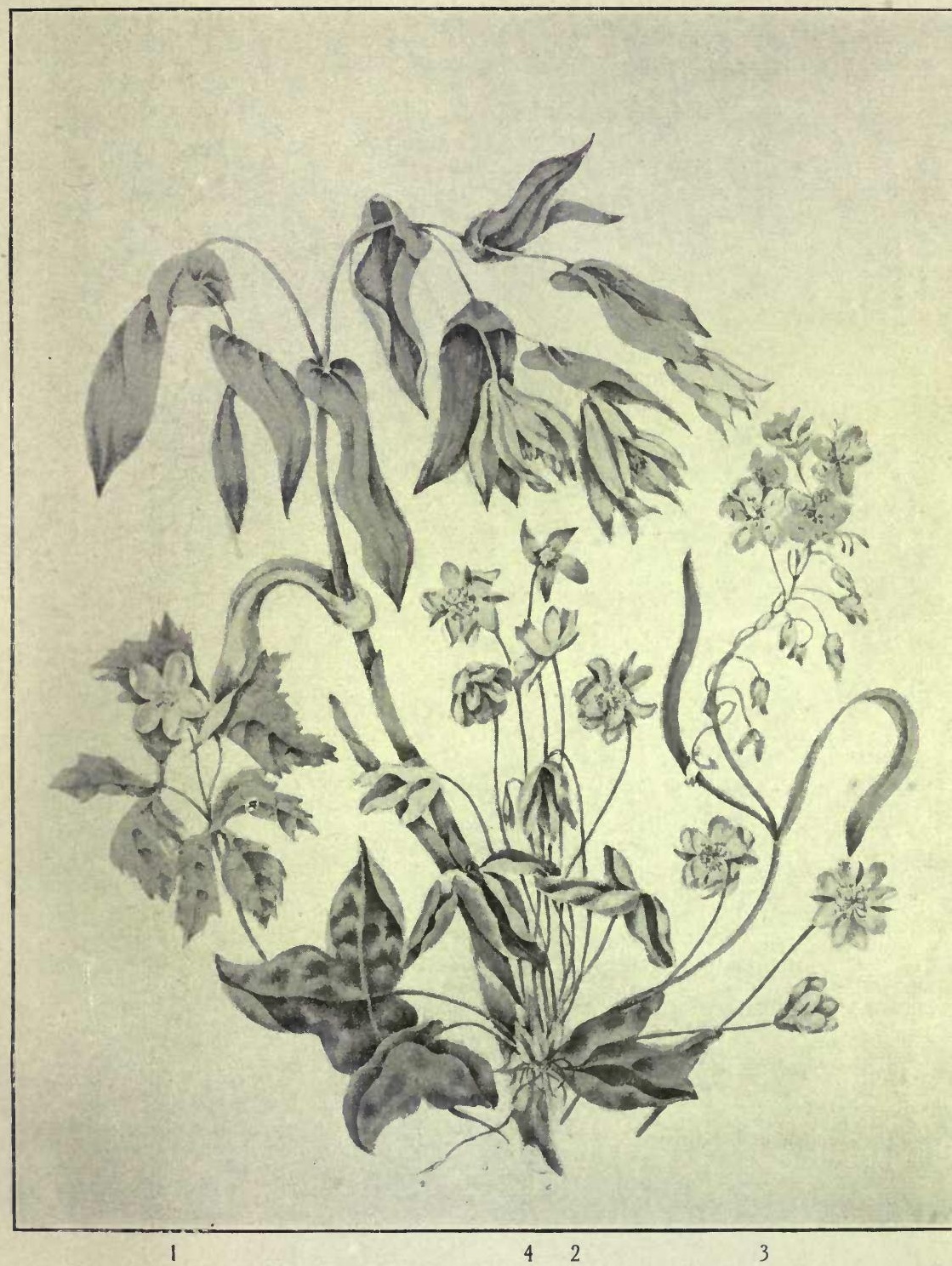



the Snow-flower or Liver-leaf is to Canada. It lingers long within the forest shade, coyly retreating within its sheltering glades from the open glare of the sun, though for a time it will not refuse to bloom within the garden borders, when transplanted early in spring. Doubtless, if properly supplied with black mould from the woods, and partially sheltered by shrubs, it would continue to grow and flourish with us constantly.

We have two sorts, $H$. acutiloba and $H$. triloba. A large variety was found on Long Island in Rice Lake, the leaves of which are five lobed; the lobes are much rounded, the leaf stalks stout, densely silky, the flowers large, of a deep purple blue. This handsome plant throve under careful cultivation, and proved highly ornamental.

The small round closely-folded buds of the Hepatica appear before the white silky leaves unfold themselves, though many of the old leaves of the former year remain persistent through the winter. The buds rise from the centre of a silken bed of soft sheaths and young leaves, as if Nature kindly provided for the warmth and protection of these early flowers with parental care.

Later in the season the young leaves expand, just before the flowers drop off. The white flowered is the most common among our Hepaticas, but varieties may be seen of many hues-waxen pink, pale blue and azure blue, with intermediate shades and tints.

This pretty native flower improves under garden culture, forming a lovely flowery border, giving us the very earliest blossoms of April and May to gladden us before any of our garden flowers open. The colors of the pink and the blue deepen in open sunny borders.

The Hepatica belongs to the Nat. Ord. Ranunculaceæ, 


\section{STUDIES OF PLANT LIFE}

the Crowfoot family, but possesses none of the acrid and poisonous qualities of the Ranunculus proper, being used in medicine, as a mild tonic, by the American herb doctors in fevers and disorders of the liver.

It is very probable that its healing virtues in complaints of the liver gave rise to its common name in old times; some assign the name, "Liver-leaf," to the form of the lobed leaf.

Blue Cohosh, Papoose Root-Caulophyllum thalictroides (Michx.).

(PLATE IV.)

Though bearing the same Indian name, "Cohosh," our plant has been removed by botanists to another family than the red and white Baneberries, or Cohoshes, which are members of the Ranunculaceæ or Crowfoot family. There is no beauty in the blossoms of the Blue Cohosh, yet the plant is remarkable for its medicinal uses; which are well known among the Indians and the herbalists of the United States medical schools.

The round, rather large blue berries are not the portion of the plant that is used, but the thick-knotted root-stock. The leaves are of a dull bluish green, the flowers dark purplish green, lurid in color; the leaves are closely folded about the thick fleshy stem when they first appear. The whole plant impresses one with the conviction that it is poisonous in its nature; there is something that looks uncanny about it. Nature stamps a warning on many of our herbs by unmistakable tokens: the glaring inharmonious coloring of some; the rank odors exhaled by others; the acrid, biting taste in the leaves and juices-all these are safeguards if we would but heed them as warn- 


\section{NATIVE WILD FLOWERS}

ings. The compound leafage of the Blue Cohosh breaks the ground in April with the immature flowers; after a while the leaf spreads out and the lurid blossoms expand. The berries are set upon short thick fleshy foot-stalks, and the round hard fruit forms a loose panicle of drupe-like naked seeds of horny texture.

The plant may be found in open woods and grassy plainlands, known by its large bluish green leafage and the dark blue berries. *

\section{BLood-Root.-Sanguinaria Canadensis (L.).}

\section{(PLATE IV.)}

"Here the quick-footed wolf, Pausing to lap thy waters, crushed the flower Of Sanguinaria, from whose brittle stem The red drops fell like blood."

Just at the margin of the forest, and in newly-cleared ground among the rich black leaf mould, may be seen late in April and May the closely-folded vine-shaped leaf of the Blood-root, enclosing in its fold one pure white bud.

The leaf is strongly veined beneath with pale orange veins. The simple semi-transparent round leaf stalk, as well as the flower scape, is filled with a liquor of a bright orange red color: break the thick fleshy tuberous root and a red fluid drops from every wounded pore, whence its local name " Blood-root." †

This juice is used largely by the Indian women in their

* The roots of this plant are in use with the Indian women, its common name being "Papoose Root." Its virtues are of a singular and powerful nature, known only to the native Indian.

+ The Indians have an old legend of the transformation of the Wood Thrush into the form of the Blood-root, which poetical fancy has been sweetly versified by a lady in Toronto, who favored me with a copy of the poem. 


\section{STUDIES OF PLANT LIFE}

various manufactures. With it they dye the porcupine quills and moose-hair both red and orange, and also stain the baskets of a better sort that they offer for sale in the stores. Nor is this the only use to which it is applied: they use the juice both externally in curing cutaneous eruptions of the skin, and internally in other diseases. Latterly its medicinal qualities have been acknowledged by the American Eclectic School of Pharmacy as valuable in many forms of disease, so that we find our beautiful plant to be both useful and ornamental.

The Blood-root grows in large beds; each knob of the root'sends up one leaf and its accompanying flower bud, which it kindly enfolds as if to protect the fair, frail blossom from the chilling winds and showers of hail and sleet. The leaf is of a grayish or bluish green; at first the underside, which is the part exposed to view, is salmon colored veined with red, but as it expands and enlarges the outer surface darkens into deeper green. The blossom is composed of many petals, varying from eight to twelve.* The many stamens are of a bright orange yellow. The stigma is two-lobed, and the style short or sessile. The seed is contained in an oblong pod of two valves. The seeds are of a bright red brown color. The ivory white petals are oblong, blunt, or sometimes pointed; the outer ones larger than the inner, at first concave, but opening out as the flower matures. Under cultivation the blossom of the Blood-root increases in size, but the plant does not

*Very rarely more than eight. It might be called an Easter flower. The two sepals fall off as the flower opens; owing to this fact few know there were any. The flower is composed of four large petals on the outside and four smaller ones inside, both forming, when separated, a perfect St. Andrew's Cross. I never saw this noticed by anyone but myself. It is so fragile a plant that it is often hard to get a perfect flower, as the petals drop when it is being plucked.-A.D.C. 


\section{NATIVE WILD FLOWERS}

seem to spread and multiply as freely as in its native soil. It is one of our most lovely native Spring flowers. It is a pity that, with the march of civilization, we shall soon lose its fair pure blossoms. It is easily cultivated, and repays care by the increase in size of the flowers, ripening the seeds perfectly and freely.

\section{TALL BUtTERCUP-Ranunculus acris (L.).}

We see in Canada this old familiar meadow-flower of our childhood bright and gay, growing abundantly in low wet pasture lands, where it becomes to the eye of the farmer a troublesome, unprofitable weed, rejected by the cattle for its bitter, acrid qualities. Yet it is pleasant to meet its old familiar face in a foreign land, where often the sight of some simple flower will awaken tender recollections of early scenes of sunny grassy meadows, where we wandered in days of thoughtless childhood, free of care as the lark that carolled above our heads in the glad sunshine; happy days brought back to memory in all their freshness by the sight of a simple yellow Buttercup blossoming in Canadian wilds and wastes, despised and rejected by others but precious to the heart of the lonely immigrant, who hails it as a tiny link between himself and his early home life.

\section{Early Crowfoot-Ranunculus fascicularis (Muhl.).}

This native species of Ranunculus is one of our earliest spring flowers. It grows low and spreading to the ground, the hairy foliage giving a hoary tint to the divided coarselycut leaves; the blossoms are of a pale yellow color, not as large as the common Buttercup. The root is a cluster of thick fleshy fibres. 


\section{STUDIES OF PLAN'P LIFE}

One of the prettiest of the Ranunculus family is the

\section{CREePING SPEARWORT-Ranunculus reptans (Gray),}

a tiny, delicate plant, with slender thready stems rooting from beneath the joints. The leaves are very narrow and pointed, those nearest to the root a little lobed or eared. The little bright golden shining flowers only a few lines broad, are borne in the axils of the leaves of the prostrate creeping stems, and peep out from the sandy soil among tufts of minute hairy sedges (Eleocharis acicularis) that clothe the damp low-lying shores of rivers or lakes. There are several Water Crowfoots, some with white flowers, others with yellow. These latter flowers float upon the surface of slow-flowing rivers or lakes, gently rising or falling with the motion of the waters. The beautiful adaptation of plants to soil and circumstances may be noticed in these and some other aquatic plants which have their foliage dissected into narrow segments, so that the water may freely flow through them. Of the water Ranunculi, we may mention White Water Crowfoot $(R$. aquatilis) and Yellow Water Crowfoot ( $R$. multifidus).

There are among our native Ranunculus flowers a few plants of which the outward beauties of their blossoms are better known to us than their useful qualities, though doubtless even the lowliest among them has a part to perform, not for man's sole benefit, but for the support or shelter of some of God's creation among the insect tribes or smaller animals or birds which find nourishment in their seeds, leaves or roots. It is a remarkable fact that rarely, if ever, is the flower of any plant selected for food by bird or beast.

There are many native plants of the order Ranunculaceæ, 


\section{NATIVE WILD FLOWERS}

- too many to be here described. Gray describes nineteen species of Ranunculi proper, only a part of the plants described being found with us, and there are doubtless many others found in our extensive Dominion not at piesent named.

The large deep golden, abundant flowers of the

\section{Marsh Marigold-Caltha palustris (L.),}

(PLATE V.)

are too well known to need any minute description. It is, indeed, a splendid flower, and can hardly fail of being admired when seen, like a " field of cloth of gold," covering the low, wet ground with its large leaves of a deep refreshing green and its rich golden cups-a pleasant sight to the eye in May. The leaves were used as a pot-herb by the tarly backwoods settlers, before garlens were planted; but, through carelessness or ignorance, accidents of a fatal nature are known to have occurred through mistaking the leaves of the Arisama triphyllum for those of the more innocent herb, the Marsh Marigold, or Water Cowslip, as this plant is often called.

\section{Mitrewort, Bishop's CAP-Mitella diphylla (L.).}

This elegant forest flower is found in moist, rich soil, among beech, maple, and other hardwood trees.

We have two species of these plants: one, Mitella nuda (L.), rather creeping, with green blossoms, only a few inches in height, and the flowers larger and fewer on the slender scape, the bright green lobed leaves spreading on the ground. The taller Mitrewort has elegant fringed cups, greenish white, many flowers arranged in a long slender spike. The term "diphylla" distinguishes it from the low 


\section{STUDIES OF PLANT LIFE}

dwarf species, there being two opposite pointed leafy bracts about the middle of the long slender scape. Not only are the fringed cap-like flowers worthy of minute attention, but the boat-shaped two-valved capsules of the seed vessels form a pretty feature in the plant. At an early stage of ripeness the shining jet black seeds appear; these are scarcely less attractive than the delicate fringed flowers, and have given rise to the local name in some places of "Gem-flower."

Nearly allied to the above is the woodland flower,

\section{False Mitrewort-Tiarella cordifolia (L.),}

(PLATE VIII.)

to which the name "Wood Mignonette" is often given, not on account of its scent-for there is no particularly agreeable odor in the flower, and the leaves are somewhat coarse and pungent in quality-but for the beauty of the light graceful blossoms, which are white with orange tipped or light tawny brown anthers. The petals are pointed and five in number; stamens ten, long and slender; styles two; seed vessels two-valved; the base of the pistil is thickened, forming a turban-like pod.

There are two forms of our pretty "Wood Mignonette" -one with closer, more globular, heads of flowers, the other with the flowers looser and more scattered. Both affect the rich black mould and shade of the forest trees.

The plant might be called evergreen, as the leaves appear green and fresh from beneath the covering of Winter's snow. The large flat sharply-toothed, lobed leaves are shaded in the centre with purple; the veinings also blackish purple, and the surface is beset with very short appressed hairs. The leaf stalks of the young plants are of a reddish pink, and are hairy at their junction with the root. 


\section{NATIVE WILD FLOWERS}

\section{Wood Betony-Pedicularis Canadensis (L.).*}

This plant is commonly found in open grassy thickets and plainlands. Of the two common species, we have one with dark dull red flowers and another with yellow. It is a rather coarse flower; the spike leafy, hairy and rough; the leaves are divided into many rounded lobes, toothed at the margins and deeply cleft, nearly to the mid-rib, turning black in drying. The yellow flowered is a smaller plant than the red; the foliage is much more hairy, and the lipped blossoms are also hairy, the upper lip arched over the lower lobes of the corolla. I think it must be a distinct variety, or even species. Lindley remarks, in his "Natural System," that the Betony is acrid in quality, but that it is eaten by goats-unluckily we have few goats in Canada to benefit by the herbage of this homely plant. $\dagger$

\section{Flowering Wintergreen-Polygala paucifolia (Willd.).}

(PLATE IX.)

This is one of our early flowering plants distinguished by the common name of "Wintergreen." It belongs to a family of well-known plants called Milkworts-low bitter herbs-some of which are remarkable for tonic properties, of which the Senega, or Snakeroot, is an example.

Some of the species are remarkable as bearing fertile flowers under ground. The flowers of some are white, others red, and others again purple or reddish lilac. The name Milkwort appears to have been adopted without any foundation, from an imaginary idea that the herbage of some of the species promoted the secretion of milk in cows. Several of the milkworts are indigenous to Canada.

* The name given to this lovely plant in English has a low, vulgar sound-- "Lousewort "-that in the native Cree language is Moostoos Ootasee."

+The Betony referred to by Lindley belongs to the Sage family. 


\section{STUDIES OF PLANT LIFE}

$P$. Senega is not evergreen in its habits; it flowers in May among grasses on dry uplands; it is simple, slender, and not ungraceful, the leafy stem terminating in a spike of greenish-white flowers. The wiry root is said to possess medicinal qualities. The plant which merits our attention more particularly for its beautiful flowers is $P$. paucifolia, the beautiful fringed, or crested, Polygala. It is a smallsized plant, about six to nine inches in height; the stem is simple, rising from a running or creeping root-stock, often furnished with subterranean imperfect leaflets and fertile flowers. The smooth dark-green leaves, delicately fringed with soft silky hairs tinged with a purplish hue, are persistent through the winter. The stem of the plant is leafy, the lower leaves småll and bract-like, the upper ones larger and clustered round the summit; from amongst these appear from two to four, and sometimes as many as five, elegantly winged purple-lilac flowers. The two upper petals are long-ovate, the lower forming a crested keel, finely tinged with deeper purple. The flowers of this beautiful species are very graceful, slightly drooping from among the shining leaves on thread-like pedicels. The stamens are six; sepals of the calyx five; petals three. Some old writers have given the name of "Fly-flower" to our pretty Polygala, and truly not an inappropriate name, as one might not inaptly liken the opened blossom to some gay purple-winged insect ready to take its flight from the bosom of the soft silky leaves that form an involucre round it.

This Flowering Wintergreen is one of our earliest Spring flowers; in fine warm seasons it appears in the latter end of April, continuing to bloom on till the middle of May. The early flowering plants are not so tall, neither are the flowers so large as those put forth later in the season. On 


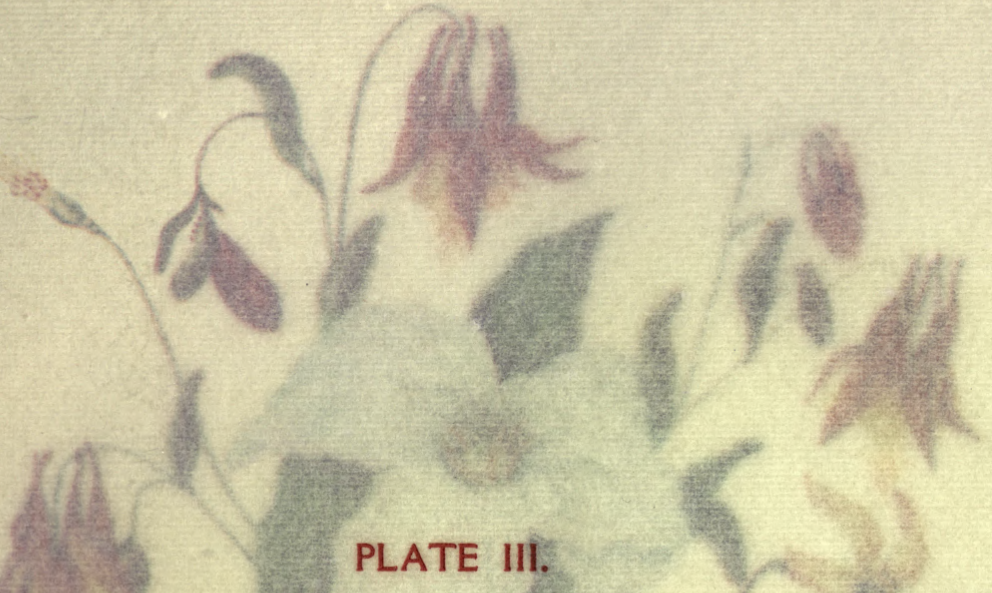

1. Large White Trillium (Trillium grandiflorum). P. 35.

2. Rock Columbine (Aquilegia Canadensis). P. 39.

3. Yellow Adder's Tongue (Erythronium Americanum). P. 33.

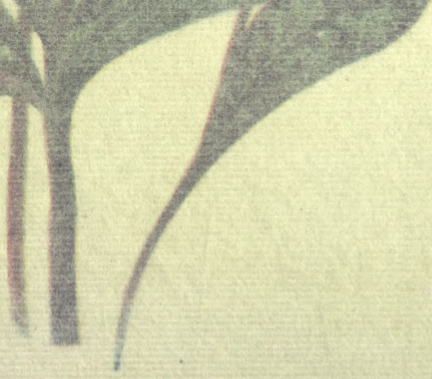




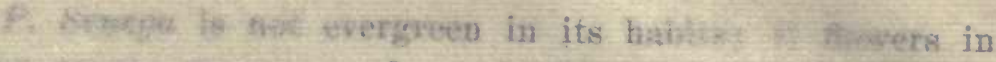

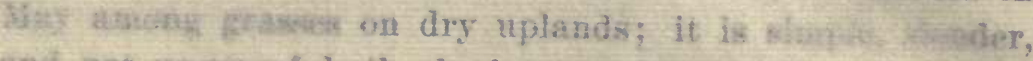
atac not angraceful, the leafy stem tetuinating las a shate of greentsh-white flewers.

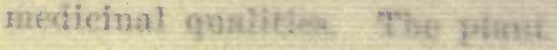

wore bartiegatiant:

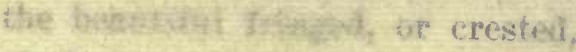

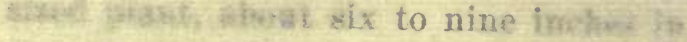

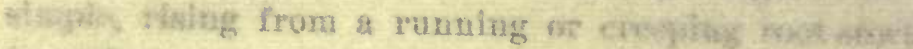

Strmisher with sabterranean imperfect leatlets diuf

flowers. The smooth dark-green leaves, delicately thaskes with soft silky hairs tinged with a purplish hne, are pet fistent through the winter. The stem of the plant is leafy, the lower leaves smill and bract-like, the upper ones larger and clustexed round the suminit; from amongst these appear trom two to forr, andII ITAd9 as many as five,

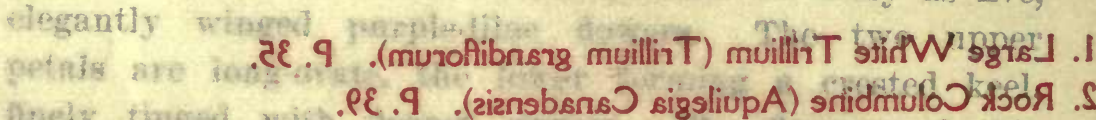

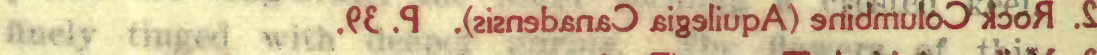

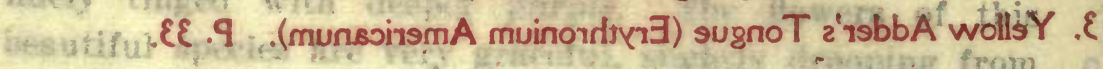

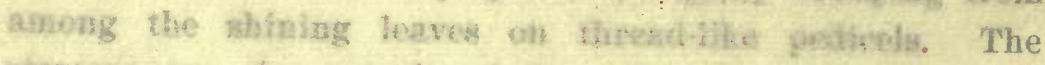

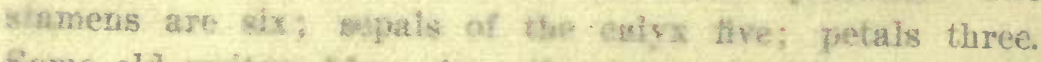
Some old writets bitre given the name of "Fly-flower" to

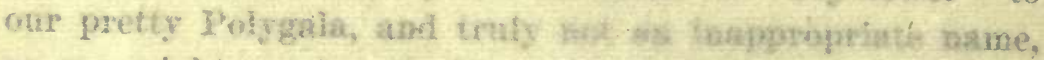

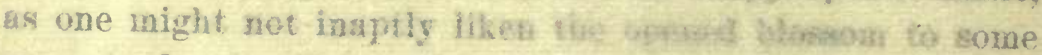
gay purple-winged insect ready th thelle ing flight from the bosom of the solt silky leaves that fhen wh involucre round it.

This Fowering Wintergreen is onw of on thplitest Spring Aowers: in fine warm seasons it appears lie the kitter end of April, continuing to blows on till tho statalte of May. The eariy flowering plants are aot so tall, neither are the flowers so large as those pot forth loter in the seasun. On 
PLATE II

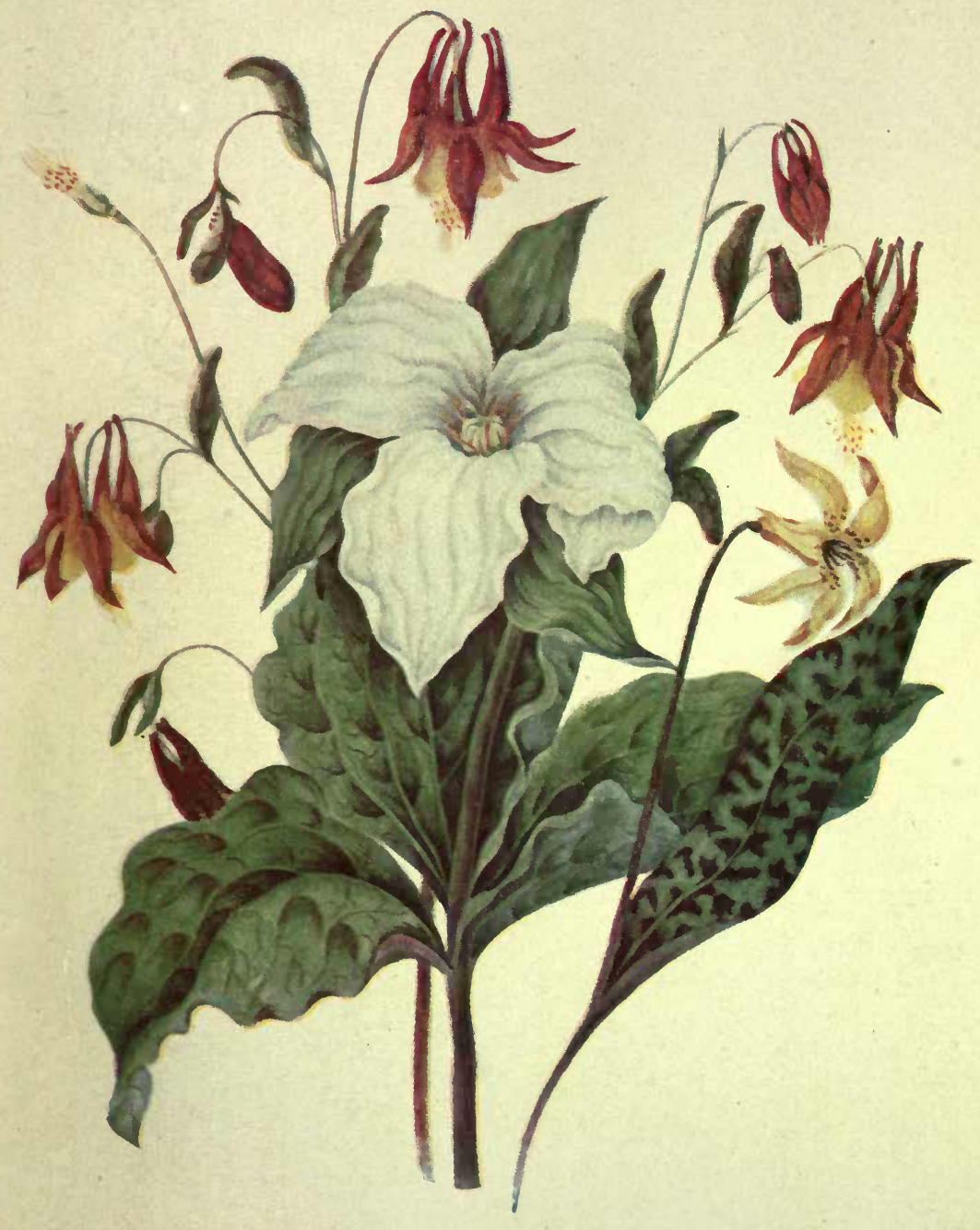



sumny spots, on moderately sandy soil, on open wastes by the wayside, or at the edge of the partly cleared forest, it expands its soft purple-sometimes rose-colored-flowers, often mingled promiscuously with the white blossoms of the Wild Strawberry and creeping Early Everlasting. The lovely winged flowers gladden the eye of the traveller when as yet but few blossoms have ventured to brave the late frosts that ofttimes nip the fair promise of the spring.

No wonder that we watch with pleasure for the reappearing of our little floral gem, as in the old times we did for the bright golden varnished flowers of the Smaller Celandine, that starred the green turfy banks in our English lanes, opening so gaily to the ruffling winds and sunshine on bright March mornings. Some of the peasants and old writers call the little Celandines "Kingcups," and I have often fancied that Shakespeare was thinking of this sweet spring flower when he wrote his charming song, "Hark, the Lark at Heaven's Gate Sings,"

\section{"And winking Mary.buds begin \\ To ope their golden eyes ; \\ With all the things that pretty bin, \\ My lady sweet, arise."}

Mary-golds, which some suppose the poet meant by Mary-buds, have little poetical charm about them, not being associated with the Lark as a wild spring flower. It is more than probable it was the gay little Celandine that he thus immortalizes with his sweet song.

The larger form of our Flowering Wintergreen is found somewhat later in May in the woods, and is known by the settlers as "Satin-flower." It would make a pretty border plant, and from its early flowering would be a great acquisition to our gardens. 


\section{STUDIES OF PLANT LIFE}

\section{American Snakeroot-Polygala Senega (L.),}

already referred to, is less ornamental, though a delicate and graceful little plant. Like the rest of the genus, its root is perennial, woody, and bitter in its qualities. The stem is simple, wand-like, clothed with lanceolate leaves, and terminating in a spike of greenish-white flowers. The wings of this species are small, and embrace the flattened, less conspicuously crested keel. Its favorite haunt is dry upland plains, among shrubs and wild grasses; it blossoms later than the more showy purple Polygala, being seen through May and June, and later through the summer.

Another purple-flowered species is

Slender Purple MilKworT-Polygala polygama (Walt.).

The flowers form slender racemes of violet-colored blossoms springing from a woody root-stock, which also bears numerous inconspicuous but more fertile flowers beneath the ground. Its usual habitat is dry grassy banks in sandy or rocky ravines; all these plants seem to prefer sunshine to shade, and favor a light sandy, loamy soil. Several of the species are used as tonics and alteratives by the American herbalists.

\section{Wood ANemone-Anemone nemorosa (L.).}

(PLATE II.)

" Within the wood,

Whose young and half-transparent leaves

Scarce cast a shade, gay circles of anemones

Danced on their stalks."

- Bryant.

The classical name "Anemone" is derived from a Greek word which signifies the wind, because it was thought that the flower opened out its blossoms only when the wind was 
blowing. Whatever the habits of the Anemone of the Grecian Isles may be, assuredly in their native haunts in this country the blossoms open alike in windy weather or in calm, in sunshine or in shade. It is more likely that the wind acting upon the downy seeds of some species and dispersing them abroad has been the origin of the idea, and has given birth to the popular name which poets have made familiar to the ear with many sweet lines. Bryant, who is the American poet of Nature, for he seems to revel in all that is fair among the flowers and streams and rocks and forest shades, has also given the name of "Wind-flower" to the blue Hepatica.

This pretty, delicate species loves the moderate shade of groves and thickets; it is often found in open pinelands of second growth, and evidently prefers a light and somewhat sandy soil to any other, with glimpses of sunshine stealing down upon it.

The Wood Anemone is from four to nine inches in height, but occasionally taller; the five rounded sepals which form the flower are white, tinged with a purplish-red or dull pink on the outside. The leaves are three-parted, divided again into three, toothed and sharply cut, and somewhat coarse in texture; the three upper stem leaves: form an involucre about midway between the root and the. flower-cup.

Our Wood Anemone is a cheerful little flower, gladdening us with its blossoms early in the month of May. It is: very abundant in the neighborhood of Toronto, on the grassy banks and piney dells of Dovercourt, and elsewhere.

"There thickly strewn in woodland bowers, Anemones their stars unfold."

A taller species, Anemone dichotoma, with very beautiful white starry flowers, is found on gravelly banks by 


\section{STUDIES OF PLANT LIFE}

river-sides and under the shade of shrubs in most parts ti: Canada, as is also the downy-seeded species known as "Thimble-weed" (Anemone cylindrica), from the cylindrical heads of fruit. This latter is not very attractive for beauty of color; the flower is greenish-white, small, two of the sepals being shorter and less conspicuous than the others. The plant is from one to two feet high; the leaves of the cut and pointed involucre are coarse, and are of a dull green, surrounding the several long flower-stalks. The soft cottony seeds remain in close heads through the winter till the spring breezes disperse them.

The largest species of our native Anemones is the Tall Anemone (A. Virginiana). This handsome plant loves the shores of lakes and streams; damp rich ground suits it well, as it grows freely in such soil, and under moderate shade when transferred to the garden.

The foliage of the Tall Anemone is coarse, growing in whorls round the stem; divisions of the leaf three parted, sharply pointed and toothed. In this, as in all the species, the colored sepals (or calyx leaves) form the flower. The outer surface of the ivory-white flower is covered with minute silky hairs; the round flattened silky buds rise singly on tall naked stems, but those of the outer series are supplied with two small leaflets embracing the stalk. The central and largest flowers open first, then the lateral or outer ones as these fade away; thus a succession of blossoms is produced, which continue to bloom for several weeks. The flowers of this plant under cultivation become larger and handsomer than in their wild state; sometimes the flowers are tinted with purple. This species is distinguished from 'A. cylindrica by its round heads of fruit and larger flowers. The Anemone is always a favorite flower wherever it may be seen, whether in British woods, 


\section{NATIVE WILD FLOWERS}

on Alpine heights, or in Canadian wilds; on banks of lonely lakes and forest streams, or in the garden parterre, where it is rivalled by few other flowers in grace of form or splendor of color.

We cannot boast, in this part of the Dominion, any of the more brilliant and beautiful flowers of this ornamental family, though that interesting, lovely species known as Pasque-flower-Anemone patens (L.), var. Nuttalliana (Gray) - is largely distributed over the prairie lands of the Western States and in our North-western Provinces, where it is one of the earliest of the spring flowers to gladden the heart with its large lavender blossoms, than which none are more beautiful. The bud appears on a thick leafless scape, about four to six inches high, enclosed in a cut and sharply pointed. involucre of grey bracts of silvery hue and shining brightness. The scape is clothed with hairy scales; from within this silky covering peeps out the fair bud, which shortly expands into a large open cup-like very beautiful blossom, with a shade of white at the base of each large pointed sepal. As the flower advances a change takes place in the whole aspect of the plant; the root-leaves begin to appear, which are compoundly cut and divided, and the head of plumy fruit is raised on a high scape above the silken involucre and now ripens in the breezy air and sunshine.*

I have a fine dried specimen before me, perfect under all its several aspects, and I wish that it could be oftener seen as a cultivated border ornament in our Canadian gardens. The name "Pasque-flower" is hardly known among the inhabitants of our North-western prairies, and the Indian name would, I am sure, be descriptive of some natural quality of the plant, its growth or habits.

*This is the Crocus Anemone of the West and has been chosen as the floral emblem of Manitoba. 


\section{STUDIES OF PLANT LIFE}

We have in Ontario several distinct species of Anemone, though none so finely colored as the prairie flower; nor can we boast of the splendid Anemones that gem the wilderness tracts of Palestine. Some travellers have suggested that it was to the brilliant blossoms of the scarlet, blue and white Anemones that the Saviour drew the attention of his disciples, while Sir James Smith has supposed-and with more probability-it was to the glowing colors of the golden flowered Amaryllis lutea, which abounds on the fields of Palestine, that He alluded in His words, "Behold the lilies of the field," etc. $\dagger$

\section{Spring Beauty-Claytonia Virginica (L.) and C. Caro- "liniana (Michx.).}

(PLATE 11.)

"Where the fire had smoked and smouldered, Saw the earliest flower of Springtime, Saw the Beauty of the Springtime, Saw the Miskodeed* in blossom."-Longfellow.

This simple, delicate little plant is one of our earliest April flowers. In warm springs it is almost exclusively an April flower, but in cold and backward seasons it often delays its blossoming time till May.

Partially hidden beneath the shelter of old decaying timbers and fallen boughs, its pretty pink buds peep shyly forth. It is often found in partially cleared beech-woods and in rich moist meadows.

In Canada there are two species: C. Caroliniana, with few flowers, white, veined with red, and both leaves and flowers larger than the more common western form; $C$. Virginica, the blossoms of which are more numerous, smaller and pink, veined with lines of a deeper rose color, forming

+A literal translation of the words is "the bright and shining ones."

* Miskodeed-Indian name for Spring Beauty. 


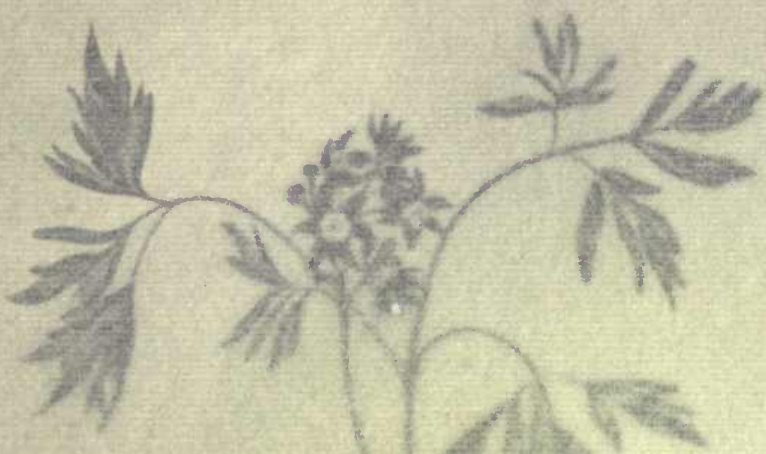

PLATE IV.

1. Blood-Root (Sanguinaria Canadensis). P. 11.

2. Blue Cohosh (Caulophyllum thalictroides). P. $\mathbf{1 0 .}$

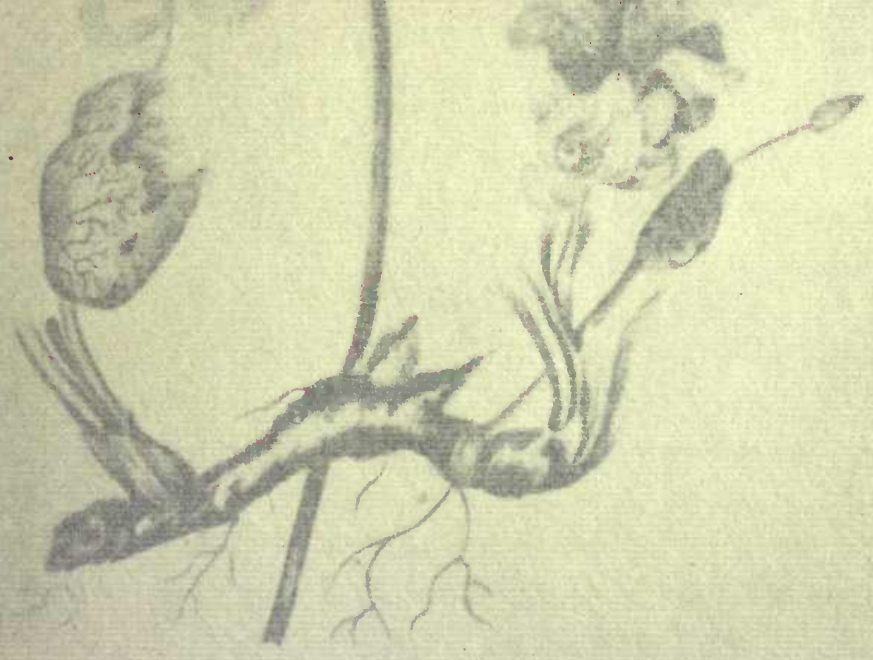




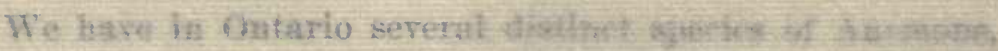

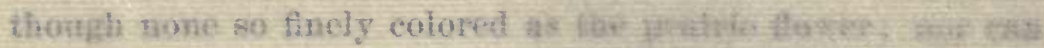

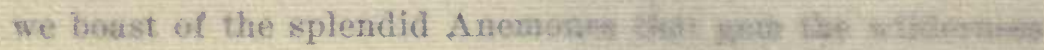

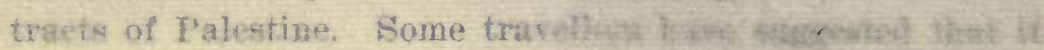

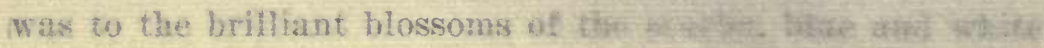

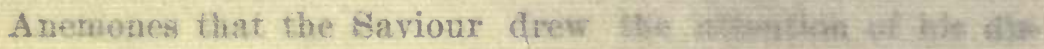

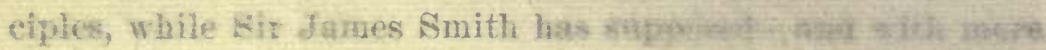

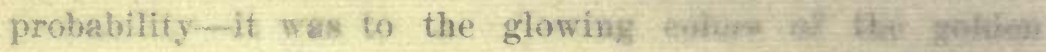

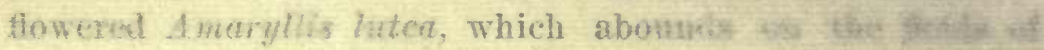

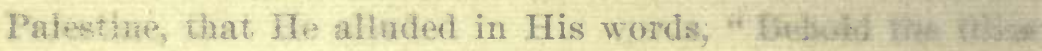
of the fleld," etc. $t$

Arrung Beauty - Claytonia Virginica (I.) and C. Caro -imiana (Migh àTA.19

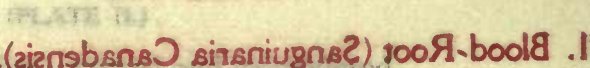

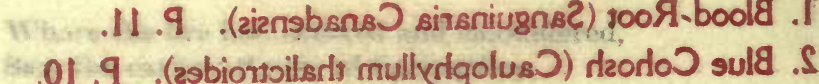

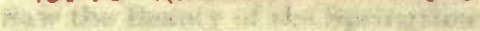

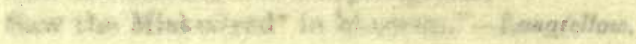

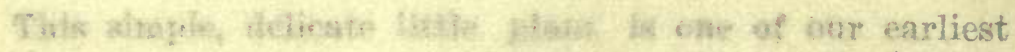

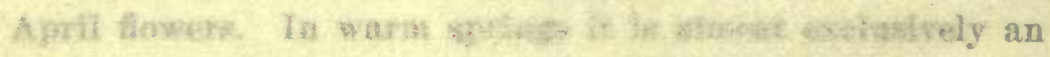

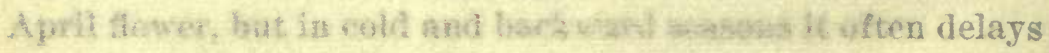
its biosomitag tione tin! May.

Partially hiditen theath the shelter of old decening timbers and fallen trangibs, in pretty pink buhls peep ofyly forth. It is often fonnd in gartalls cleared beech-wouls and in rich moist meacows

In Canada there are two speries: U. Crwilindas, with few flowers, white, redsedt with Fed, and holk ietses and flowers larger than the thom enamon westem fotm; $\Theta$. Vir. ginica, the blossoms of wibth wre more nuatsfous, smaller and pink, veined with lizes of a desper rose colnt, forming

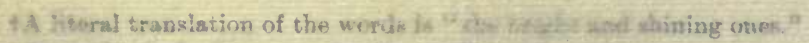

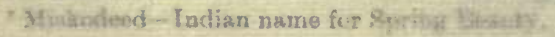


PLATE IV.

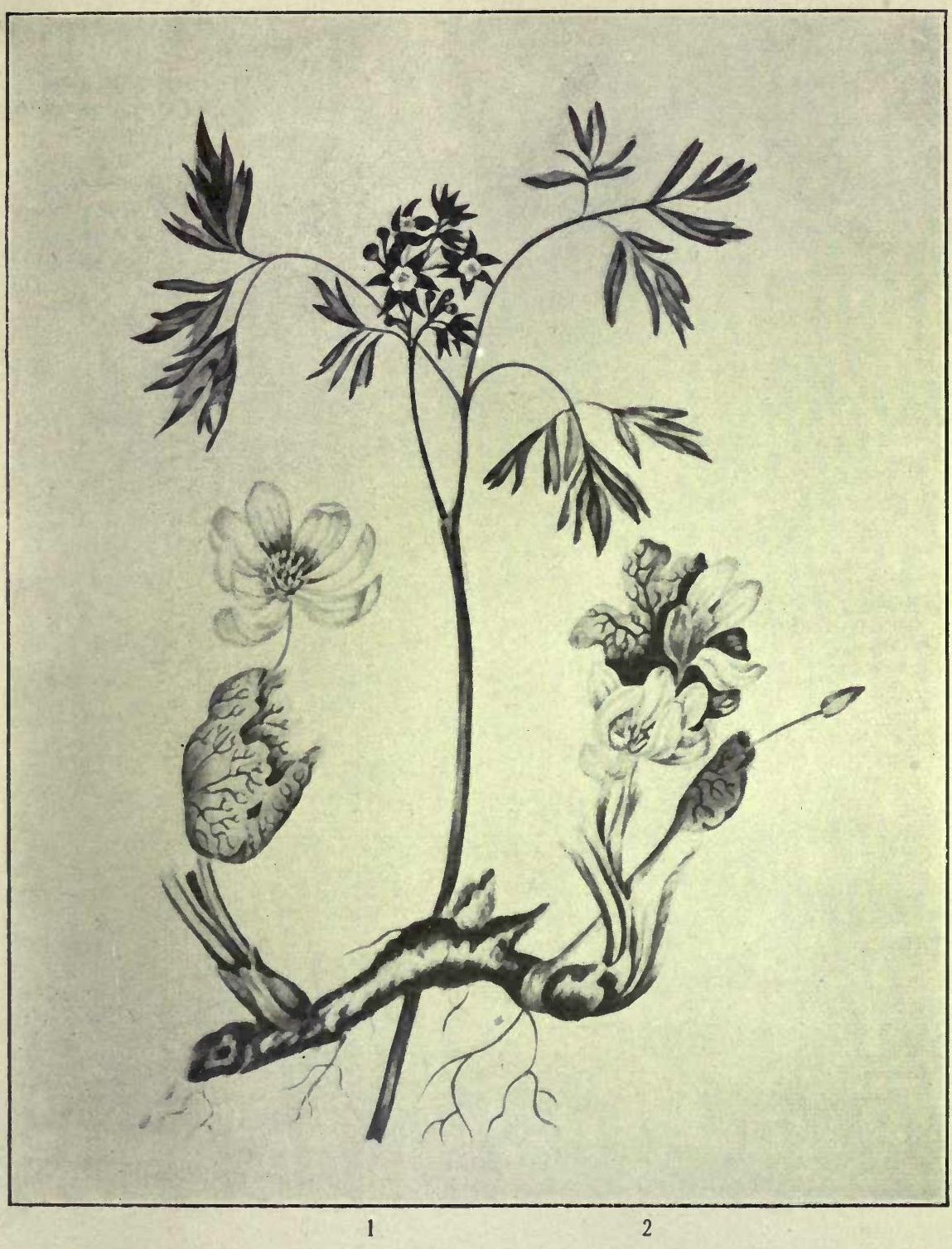





\section{NATIVE WILD FLOWERS}

a slender raceme; sometimes the little pedicels or flowerstalks are bent or twisted to one side, so as to throw the flowers all in one direction, as in the figure given in Pursh's work before alluded to.

The scape springs from a small deep tuber, bearing a single pair of soft oily succulent leaves. In the white-flowered species ( $C$. Caroliniana) these leaves are placed about midway up the stem, but in the pink ( $C$. Virginica) the leaves lie closer to the ground and are smaller and narrower, of a dark bluish-green hue. Our Spring Beauties well deserve their pretty poetical name. They come in with the robin and the song sparrow, the hepatica and the first white violet; they linger in shady spots, as if unwilling to desert us till more sunny days have wakened up a wealth of brighter blossoms to gladden the eye; yet the first and the last are apt to be most prized by us, with flowers as well as other treasures.

How infinitely wise and merciful are the arrangements of the Great Creator! Let us instance the connection between bees and flowers. In cold climates the former lie torpid, or nearly so, during the long months of winter, until the genial rays of the sun and light have quickened vegetation into activity and buds and blossoms open their stores of nutriment necessary for the busy insect tribes.

The bees seem made for the blossoms, the blossoms for the bees. On a bright March morning what sound can be more in harmony with the sunshine and blue skies than the murmuring of the honey bees in a border of cloth-of-gold Crocuses? What sight more cheerful to the eye? But I forget. Canada has few of these sunny flowers, and no March days like those that woo the hive bees from their winter dormitories. And even April is with us only a name. We have no April month of rainbows, suns and showers. We miss the deep blue skies and silver throne-like clouds that 


\section{STUDIES OF PLANT LIFE}

- cast their fleeting shadows over the tender springing grass and grain; we have no mossy lanes odorous with blue violets, and our April flowers are, comparatively speaking, few, and so we prize our early violets, hepaticas and spring beauties. We miss the turfy banks studded with starry daisies, pale primroses and azure bluebells.

In the warmth and shelter of the forest vegetation appears. The black leaf-mould, so light and rich, quickens the seedlings into rapid growth, and green leaves and opening buds follow soon after the melting of the snows of winter. The starry blossoms of the spring plants come forth and are followed by many a lovely flower, increasing with the more genial seasons of May and June.

Our May is bright and sunny, more like to the English March; it is, indeed, a month of promise-a month of many flowers. But too often its fair buds and blossoms are nipped by frost, and "winter, lingering, chills the lap of May."

\section{INDIAN TuRnip-Arisama triphyllum (Torr.).}

(PLATE VII.)

"Or peers the arum from its spotted veil."-Bryant.

There are two species of Arum found in Canada, the larger of which is known as Green-dragon (A. Dracontium ); the other is known by the familiar name of Indian Turnip (A. triphyllum or A. purpureum).

These moisture-loving plants are chiefly to be found in rich black swampy mould, beneath the shade of trees and rank herbage, near creeks and damp places in or about the forest.

The sheath that envelopes and protects the spadix, or central column which supports the clustered flowers and fruit, is an incurved membranaceous hood of a pale green color, beautifully striped with dark purple or brownish- 
purple. The flowers are inconspicuous, hidden at the base of the scape by the sheath. They are of two kinds, the sterile and fertile; the former, placed above the latter, consisting of whorls of four or more stamens and two to four-celled anthers; the fertile or fruit-bearing flowers of one-celled ovaries. The fruit when ripe is bright scarlet, clustered round the lower part of the round fleshy scape. As the berries ripen the hood or sheath withers and shrivels away to admit the ripening rays of heat and light to the fruit.

The root of the Indian Turnip consists of a round wrinkled fleshy corm, sometimes over two inches in diameter; from this rises the simple scape or stem of the plant, which is sheathed by the base of the leaves. These are on long naked stalks, divided into three ovate pointed leaflets, waved at the edges.

The juices of the Indian Turnip are hot, acrid, and of a poisonous quality, but can be rendered useful and harmless by the action of heat; the roots roasted in the fire are no longer poisonous. The Indian herbalists use the Indian Turnip in medicine as a remedy in violent colic, long experience having taught them in what manner to employ this dangerous root.

The Arisæma belongs to the natural order Aracece, most plants of which contain an acrid poison, yet under proper care can be made valuable articles of food. Among these are the roots of Arum (Colocasia) mucronatum, and others, which, under the more familiar names of eddoes and yams, are in common use in tropical countries. (Lindley.)

The juice of A. triphyllum, our Indian Turnip, has been used, boiled in milk, as a remedy for consumption.

Portland Sago is prepared from a larger species, Arum maculatum (Spotted Arum). The corm, or root, yields a 
fine white starchy powder, similar to Arrowroot, which is prepared much in the same way as Potato starch. The pulp, after being ground or pounded, is thrown into clean water and stirred; after settling the water is poured off and the white sediment is again submitted to the same process until it becomes quite pure and is then dried. A pound of this starch may be made from a peck of the roots. The roots should be dried in sand before using. Thus purified and divested of its poisonous qualities, the powder so procured becomes a pleasant and valuable article of food, and is sold under the name of Portland Sago or Portland Arrowroot.

When deprived of the poisonous acrid juices that pervade them, all our known species may be rendered valuable both as food and medicine; but they should not be employed without care and experience.

There seems in the vegetable world, as well as in the moral, two opposite principles, the good and the evil. The gracious God has given to man the power, by the cultivation of his intellect, to elect the good and useful, separating it from the vile and injurious, thus turning that into a blessing which would otherwise be a curse.

"The Arum family possesses many valuable medicinal qualities," says Dr. Charles Lee, "but would nevertheless become dangerous poisons in the hands of ignorant persons."

The useful Cassava, Jatropha manihot (Lin.), of the West Indies and tropical America, is another remarkable instance of Art overcoming Nature and obtaining a positive good from that which in its natural state is evil; the Cassava flour from which the bread made by the natives is manufactured, being the starchy parts of a poisonous plant of the Euphorbia family, the milky juice 


\section{NATIVE WILD FLOWERS}

of which is highly acrid and poisonous. The pleasant and useful article sold in the shops under the name of Tapioca is also made from the Cassava root.

How well do I recall to mind the old English Arum, known by its familiar names among the Suffolk peasantry as "Cuckoo-pint," "Jack-in-the-Pulpit" and "Lords and Ladies." The first name doubtless was suggested from the appearance of the plant about the time of the coming of that herald of spring, the Cuckoo; the hooded spathe, shrouding the spadix like a monkish cowl, must have furnished the second; while the distinction in color between the deep purplish-red and the creamy white of the central column or spadix supplied the more euphonious term of "Lords and Ladies," which to our childish fancies represented the masculine and feminine element in the plant. Of course, we dreamed not of the Linnæan system; the one was the lord because it was dark, the other the lady because it was fair and more delicate.

Squirrel CoRN-Dicentra Canadensis (DC.). (PLATE VI.)

This elegant species belongs to the Fumitory family and is remarkable for its sweetness, as well as for the grace of its almost pellucid white or pale pink bells and the finely dissected compound foliage of a peculiar bluish tint of green. The corolla is heart-shaped, with slightly rounded blunt spurs, the tips of the petals projecting and rather more distinctly colored. There is a fine variety of this flower with larger, more drooping bells, and of a decidedly pink shade.

In the rich black mould of the forest and in rather damp situations this species, known by old settlers as Squirrel Corn and by others as Wood Hyacinth, may be found. The 


\section{STUDIES OF PLANT LIFE}

sweet scent of the fresh flowers evidently suggested the last name. The round clusters of orange bulblets that are found at the base of the scape no doubt gave rise to the more common name Squirrel Corn. Whether or not these grainlike looking bulbs are eaten by the little ground squirrels I do not know; the fact depends upon the authority of the Indians and old woodsmen, so we assume it is correct.

In studying the habits of this and the next species of the genus Dicentra, I have noticed some peculiarities of growth in these interesting plants which appear to have escaped the attention of the more learned botanical writers. One thing may here be mentioned, which is the total and very rapid disappearance of the-whole plant directly the flower has perfected and ripened the seed, which is about a month after the plant has bloomed. The fine and elegantly dissected compound leaves wither away, leaving not a wreck behind to mark where the plant had grown; delicate seedlings, indeed, may be detected near where the older plant stood, and a few golden bulblets may be found near by under the mould, but not a vestige of the original plant remains. These golden slightly flattened bulbs are intensely bitter, but not acrid or biting. I think the tiny seedlings are not the offspring of these bulbs, but of the real seed; yet the bulbs will vegetate and produce living plants, as in the Tiger Lily.

All the species flourish under cultivation and become very ornamental early border flowers; but care should be taken to plant them in rich black vegetable mould, the native soil of their forest haunts.

This family contains another very charming species to which the outlandish and vulgar name of "Dutchman's Breeches" has been given, and I am sorry to say this name has been retained in Dr. Gray's manual. A far prettier and more appropriate, because descriptive, name would be that of 


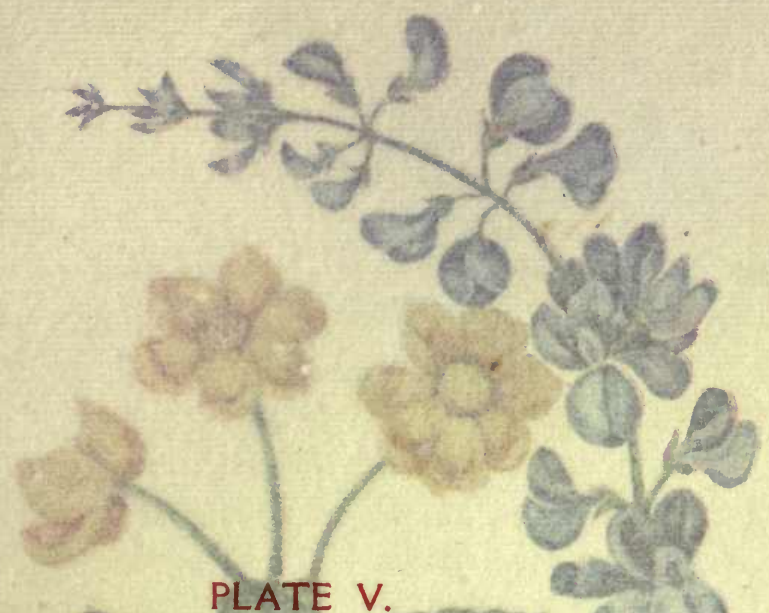

PLATE V.

1. Marsh Marigold (Caltha palustris). P. 15.

2. Wild Lupine (Lupinus perennis). P. 68 . Wyy,

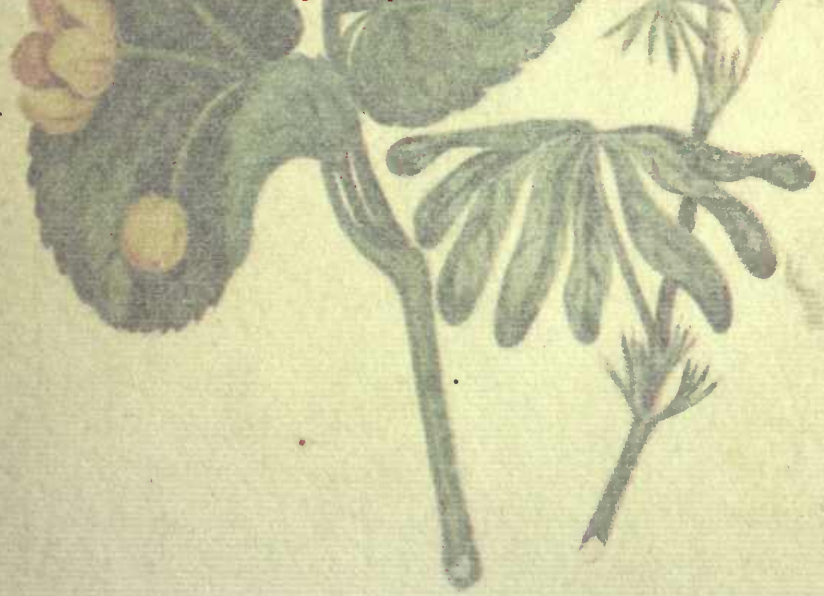




\section{STUDIES OF PIANIT HET}

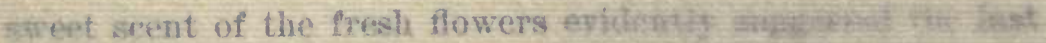
Bates The round clusters of orantig

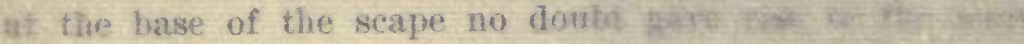

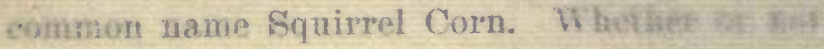
The looking bulbs are eaten by the lithly phathet do not know; the fact depends upon Jartians and oll woodsmen, so we assmue if th cithes:

In studying the tabits of this and the nest of

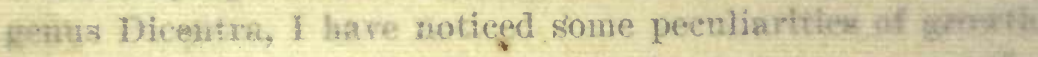
in these interesting plants which appear to bave eseapel the attration of the more learned botanical writers. One thith may here be mentioned, which is the total and very fapur disappearance of the whole plant directly the dewer lank perfected and ripened the seed, .V after the plant has bloomed. The five and elegantly dis

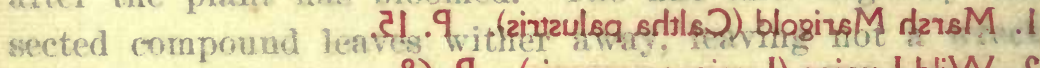
behind to mark where 80 , 9 pr (ainnsrsg zupriqud) sniqu J bliW .S

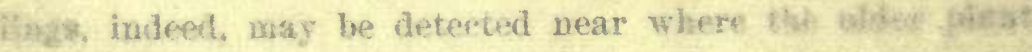

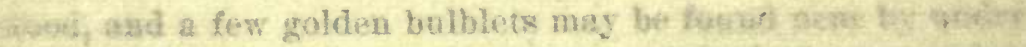
fee nomald, bet not a vestige of the onightant pts

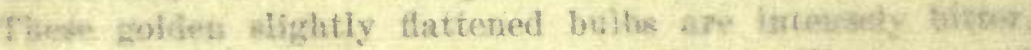
bar eot restid or biting. I think the ting secilings aze atos. the offepring of these bullis, but of the real seved; yet the forling will regetale and produce liviag plants, as in the Ther Lily.

A13 the species flonrish under cultivation asd become very crusmantal enrly border flowers; bit mese should be taken to fint then is rich black regetable monde, the mative soil of theh fromest havints.

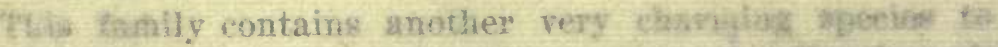
Which the outlardish and wrigar neme ef " Dutchinan?

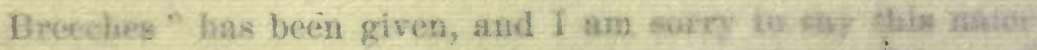

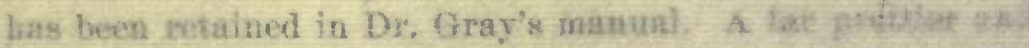

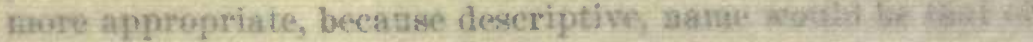


plate V.

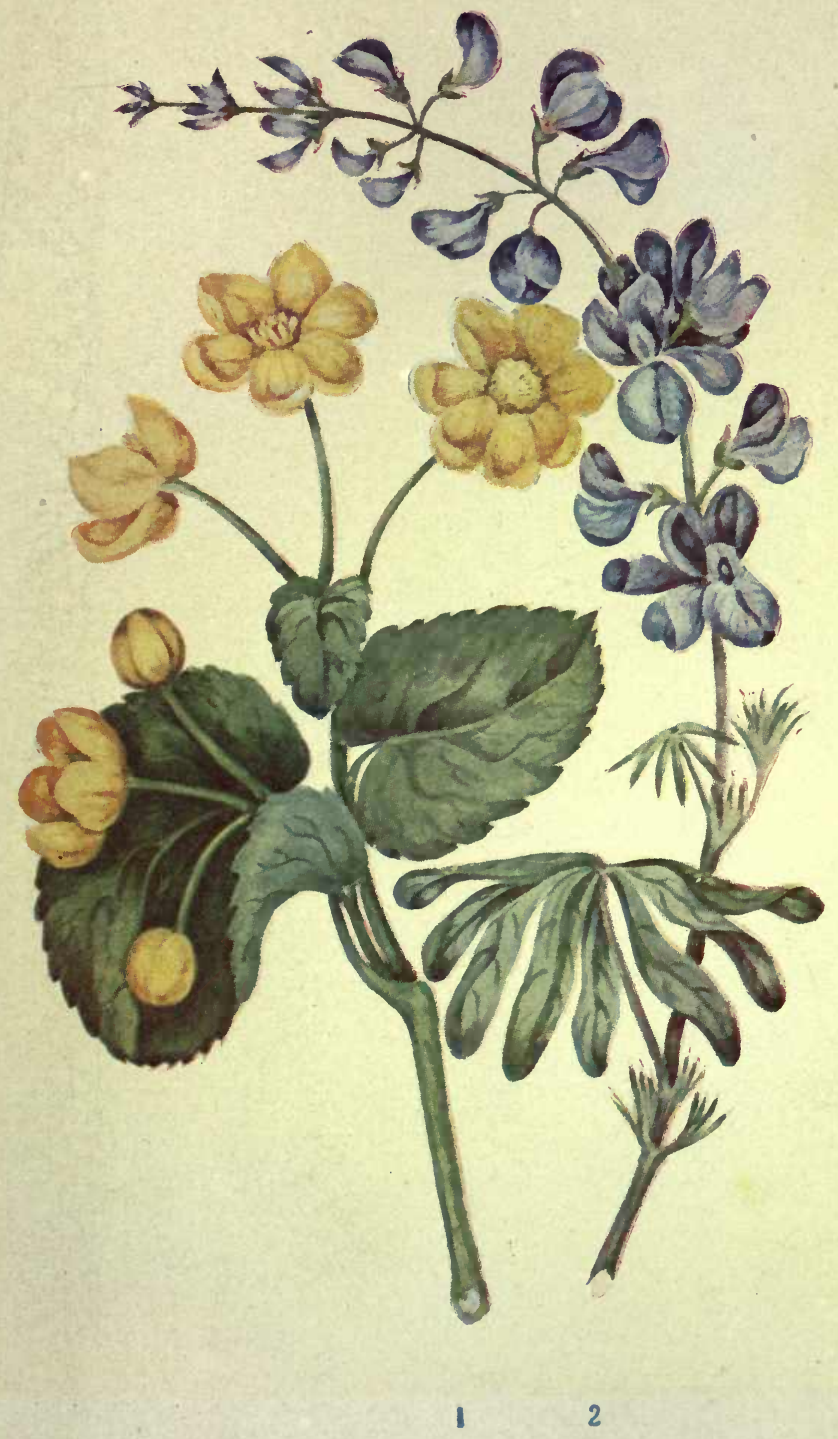





\section{NATIVE WILD FLOWERS}

\section{Fly-Flower-Dicentra Cucullaria (DC.),}

the diverging nectaries taking just the angle of the wings of the Deer-fly when spread for flight, and the brown tips of the four petals giving the semblance of the head of the insect. The delicate pale primrose-tinted sac-like spurs of the corolla give a peculiar aspect to this very attractive flower, which forms one of the ornaments of the spring. It appears early in the month of May, or, in warm and genial seasons, as early as the latter weeks in April. Like the Squirrel Corn, the foliage is finely dissected and ample; it blooms, however, a week earlier.

\section{GOLDEN FuMITORY-Corydalis aurea (Willd.).}

This pretty flower is also one of our native Fumitories; it makes a good border bloomer, is biennial in habit, seeds itself and blossoms freely. It is a low-growing, bushy plant, with pale bluish finely dissected foliage and simple racemes of golden yellow flowers; it begins to blossom very late in May and continues all through June and later. There is a finer, larger, more compactly growing plant, with larger flowers and foliage, found in rocky woods and islands in our backwoods' lakes. A very pretty species is Corydalis glauca (Pursh). This is tall and branching, with delicate flowers of bright pink, yellow and green, or white. The foliage is very blue in shade, not very abundant; the divisions of the leaf bluish; pods very slender, splitting and shedding bright shining seeds. It is a very pretty plant, and grows readily among grasses and other wayside herbage. *

* On rocky islands this very elegant species may be found in profusion, growing luxuriantly in the clefts of the gneiss rocks, and where the soil is black with decomposed vegetable mould; it will bear to be removed, and grows freely in the garden. 


\section{STUDIES OF PLANT LIFE}

Red Baneberry, Red Cohosh-Actca spicata (L.), var. rubra (Gray).

The Red Cohosh is a larger plant than the Blue Cohosh, with foliage coarsely reined, pointed in the divisions, of a full green, sharply cleft, and toothed; flowers white in a close-tufted terminal raceme. The berries when ripe are oval, shining, of a deep red, set on slender stalks; it grows in damp, rich woods.

\section{White CoHosh-Actoca alba (Bigel.).}

This is a striking-looking plant when in ripe fruit; the berries are white and shining, set on rose-red fleshy footstalks; the plant is branching and inclined to fall prostrate from the weight of the long-stalked cluster of heavy fruit. In some of its peculiar characteristics it seems to resemble the Blue Cohosh; the Indian herbalists evidently considered they were of the same nature. In none of these plants is the fruit edible.

\section{BELLWORT-WOOD DAFFOdL-Uvularia grandiflora (Smith). \\ (PLATE II.)}

" Fair Daffodil, we weep to see

Thee haste away so soon, As yet the early rising sun

Has not attained his noon.

Stay, stay!-

Until the hasting day

Has run

But to the evening song;

When, having prayed together, we

Will go with you along."

-Herrick.

This slender drooping flower of early spring is known by the name of Bellwort, from its pendent lily-like bells; and 


\section{NATIVE WILD FLOWERS}

by some it is better known as the Wood Daffodil, to which its yellow blossoms bear some remote resemblance.

The flowers of the Bellwort are of a pale greenish yellow; the divisions of the petal-like sepals are six, pointed and slightly twisted or waved; the flowers droop from slender thready pedicels terminating the branches; the stem of the plant is divided into two portions, one of which is generally barren of flowers. The leaves are of a pale green, smooth, and in the largest species perfoliate, clasping the stem.

The root-stock or rhizome is white, with fleshy roots. The Bellwort is common in rich shady woods and grassy thickets and on moist alluvial soil on the banks of streams, where it attains to the height of two feet. It is an elegant but not very showy flower, remarkable more for its graceful pendent straw-colored or pale yellow blossoms than for its brilliancy. It belongs to a sub-order of the Lily tribe. There are three species in Canada-Uvularia grandiflora, $U$. perfoliata and $U$. sessilifolia.

\section{ADDER'S-TONGUE-DOG-TOOTH VIOLET-Erythronium Americanum (Smith).}

(PLATE III.)

" And spotted adder's-tongue, with drooping bell, Greeting the new-born spring."

In rich black mould on the low banks of creeks and open woodlands large beds of these elegant Lilies may be seen piercing the softened ground in the month of April; the broad lanceolate leaves are beautifully clouded with purple or reddish brown, and sometimes with milky white. Each bulb of the second year's growth produces two leaves, and between these rises a round naked scape (or flower stem), 
terminated by a drooping yellow bell. The unfolded bud is striped with lines of dark purple. A few hours of sunshine and warm wind soon expand the perianth, composed of six colored recurved segments which form a lily-like turban-shaped flower; each segment is grooved, and spotted at the base with oblong purplish-brown dots. The outer surfaces of three of the colored flower leaves are marked with dark lines. The stamens are six; anthers oblong; pollen of a brick-red, or dull orange color, varying to yellow. The style is club-shaped; stigmas three, united.

This elegant Lily even when expanded bends downward as if to hide its glories from the full glare of the sunlight. The clouded leaves are of an oily smoothness, resisting the moisture of rain and dew. This is one of the most elegant of our native Lilies and is well worth cultivation. It blossoms early in May or late in April, and we hail it with gladness when it brightens us with a graceful golden bell at the edge of the dark forest.

The name Dog-tooth Violet seems very inappropriate. The pointed segments of the bell may have suggested the resemblance to the teeth of a dog; but it is difficult to trace any analogy between this flower and the Violet, no two plants presenting greater dissimilarity of form or habit than the Lily and the Violet, though often blended in the verse of the poet. The American name, Adder's-tongue, is more significant.* This name must refer to the red pointed anthers rather than the foliage, as some have suggested.

The White-flowered Adder's-tongue, Erythronium albidum (Nutt.), grows in the more western portions of Canada, as on the shores of Lake Huron.

* The name Dog-tooth refers to the shape of the small pointed white bulbs of the common European species, so well known in English gardens.-Prof. Lawson. 


\section{NATIVE WILD FLOWERS}

White Trillium-Easter Flower-Trillium grandiflorum (Salisb.).

(PLATE III.)

"And spotless lilies bend the head Low to the passing gale."

Nature has scattered these remarkable flowers with no niggardly hand over hill and dale, wide shrubby plain and shady forest glen. In deep ravines and on rocky islets the bright snow-white blossoms of the Trilliums greet the eye and court the hand to pluck them. The old people in this part of the province call them by the familiar name of lily. Thus we have Asphodel Lilies, Douro Lilies, etc. In Nova Scotia they are called Moose-flowers, probably from being abundant in the haunts of moose-deer. In some of the New England States the Trilliums, white and red, are known as the "Death-flower," but of the origin of so ominous a name we have no record. We might imagine it to have originated in the use of the flower to deck the coffins or graves of the dead. The pure white blossoms might serve not inappropriately for emblems of innocence and purity when laid upon the breast of the early dead. The darker and more sanguine hue of the red species might have led to its selection for such as fell by violence; but. these are mere conjectures. A prettier name has been given to the Nodding Trillium ( $T$. cernuum), that of "Smiling Wake-robin," which seems to be associated with the coming of the cheerful chorister of early spring, "the household bird with the red stomacher," as Bishop Carey* calls the robin redbreast. The botanical name of the Trillium is derived from trilix, triple, all the parts of the plant being in threes. Thus we see the round fleshy scape furnished

*An old writer in the time of James I. and tutor to one of the daughters of Charles I. 
with three large sad green leaves, two or three inches below the flower, which is composed of a calyx of three sepals, a corolla of three large snow-white or else chocolate red petals, the styles or stigmas three, ovary three-celled, and the stamens six (which is a multiple of three). The white fleshy tuberous root is much used by the American schools of medicine in various diseases, also by the Indian herb doctors.

Trillium grandiflorum is the largest and most showy of the white species. Trillium nivale, or Lesser Snowy Trillium, is the smallest; this last blooms early in May. May and June are the months in which these flowers appear. The whiteflowered Trilliums are subject to many variations and accidental alterations. The green of the sepals is often transferred to the white petals in $T$. nivale; some are found handsomely striped with red and green, and in others the very footstalks of the almost sessile leaves are lengthened into long petioles. The large White Trillium is changed, previous to its fading, to a dull reddish lilac.

\section{Purple Trillium-Birthroot-Trillium erectum (Lin.).}

(PLATE VI.)

" Bring flowers, bring flowers, o'er the bier to shed, A crown for the brow of the early dead.

Though they smile in vain for what once was ours, They are love's last gift-bring flowers, bring flowers."

-Hemans.

Gray and other botanical writers call this striking flower "Purple Trillium"; it should rather be called red, its hue being decidedly more red than purple; and in the New England States it is called by the country folks the Red Death-flower, in contrast to the larger White Trillium or White Death-flower. T. erectum is widely spread over the 


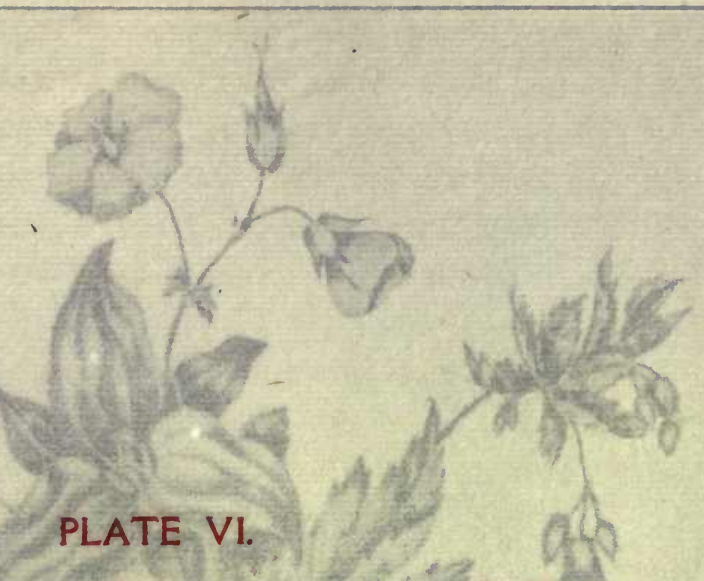

1. Wood Geranium (Geranium maculatum). P. 58.

2. Purple Trillium (Trillium erectum), P. 36.

3. Squirrel Corn (Dicentra Canadensis). P. 29.

4. Star Flower (Trientalis Americana). P. 60.

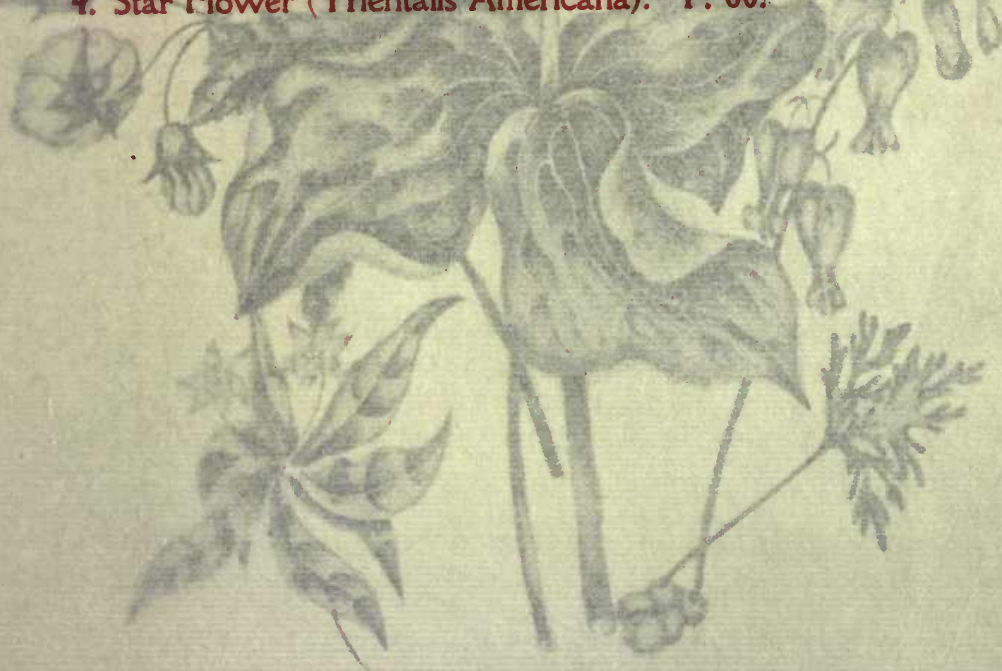


Fith three large fad green

brow the flower, which is xim

gepraik, a corolitin of three large

red petals, flue atoting of stigatias

and the sermatse six (which is if

white ffeshly twiterous root is math

sehowis of mesticine in various disenine

herib doctors.

Trillium grendifiorum is the largest ast of the white species. Trillium nivale, or bused Trillium, is the smallest; this last blooms early May and June are the montiv aTAligh these thown

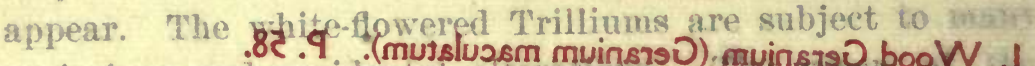

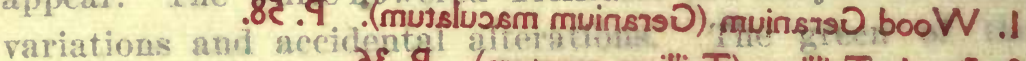
.วE. 9 .(mujos7s muillinT) muillinT slqnu9 s

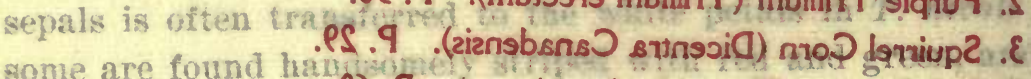

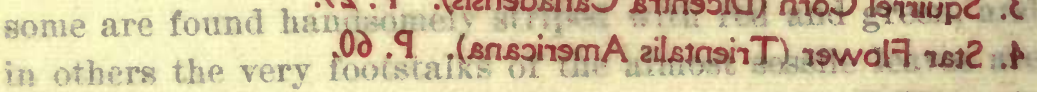
lengthened into long petioles. The large Whith 'Fnilium is

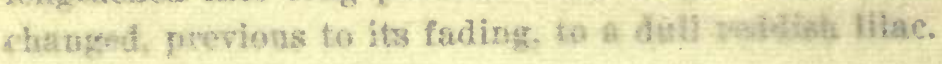

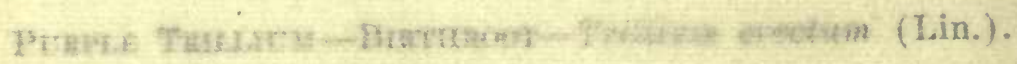

(PATE Vis

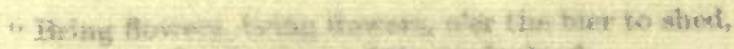

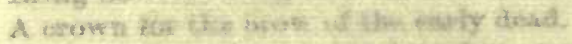

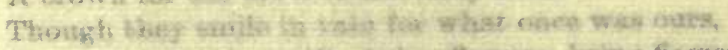

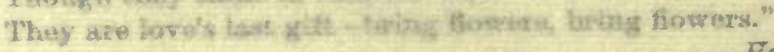

- Fiemans.

Gray and other botanical writem eall this striking flower "Purple Trillium"; it shentel rather be called red, its hue belug decidenly more ret than promples and in the New Eighand States it is called by the eountry folks the Red Deatb-foser, in contrast to the larger White rrillium or White leath-dower. $T$. erectum in widely spread over the 


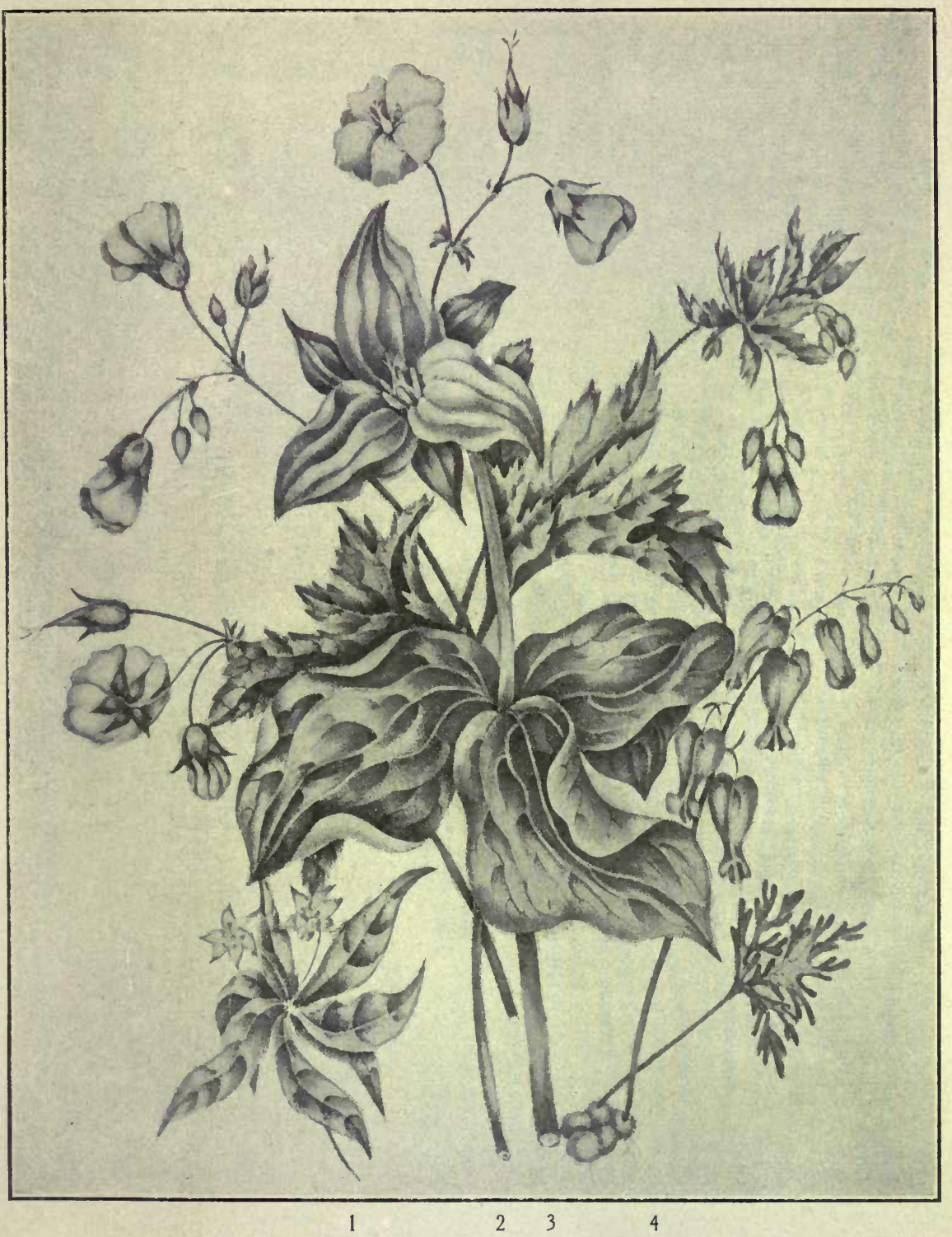





\section{NATIVE WILD FLOWERS}

whole of old Canada. It appears in the middle of May and continues blooming till June, preferring the soil of damp, shady woods and thickets; but it takes very kindly to a shaded border in the garden, where it increases in size and becomes an ornamental spring flower.

"Few of our indigenous plants surpass the Trillium in elegance and beauty, and they are all endowed with valuable medicinal properties. The root of the Purple Trillium is generally believed to be the most active. Tannin and Bitter Extract form two of its most remarkable ingredients." So says that intelligent writer on the medicinal plants of North America, Dr. Charles Lee.

The Red Trilliums are rich but sombre in color, the petals are longish-ovate, regular, not waved, and the pollen is of a greyish dusty hue, while that of the white species is bright orange yellow. The leaves are of a dark lurid green, the coloring matter of the petals seeming to pervade the leaves. And here let me observe that the same remark may be made of many other plants. In purple flowers we often perceive the violet hue to be perceptible in the stalk and under part of the leaves, and sometimes in the veins and roots. Red flowers, again, show the same tendency in stalk and veins. Where the flower is white the leaves and veinings, with the stem and branches, are for the most part of a lighter green, more inclining to the yellow or else bluish tinge of green.

The Blood-root in its early stage of growth shews the orange juice in the stem and leaves, as also does the Canadian Balsam and many others that a little observation will point out. The coloring matter of flowers has always been more or less of a mystery to us; that light is one of the great agents can hardly for a moment be doubted, but something also may depend upon the peculiar quality of the 


\section{STUDIES OF PLANT LIFE}

juices that fill the tissues of the flower, and on the cellular tissue itself. Flowers deprived of light, we know, are pallid and often colorless, but how do we account for the deep crimson of the beetroot, the rose-red of the radish, the orange of the rhubarb and carrot, which roots, being buried in the earth, are not subject to the solar rays? The natural supposition would be that all roots hidden from the light would be white, but this is by no means the case. The question is one of much interest and deserves the attention of all naturalists, and especially of the botanical student.

What shall we say to the rich color of the ruby, carbuncle, amethyst, topaz and emerald, taken from the darkness of the mine; can it be that all are really colorless till the light is admitted to them and the different conditions of the crystallized forms catch, imprison and forever hold fast the glorious rays of light?

\section{Painted Trillium-Trillium erythrocarpum (Mx.).}

(PLATE IX.)

This beautiful ornamental species is of rare occurrence in our woods. The flower is elegantly tinged with soft pink veinings on the white waved and pointed petals; the base of each is richly colored and shaded from deep red to pale rose, which color indeed is slightly diffused through the flower; leaves distinctly petioled, broad at the base, waved at the margins and sharply pointed; the whole plant from six to nine inches in height. The specimen from which the drawing is taken was found in May, near Ottawa, where it is not uncommon. The under-surface of the leaves is slightly tinged with purple.

Though scarce in our western woods, Gray says the 


\section{NATIVE WILD FLOWERS}

Painted Trillium may be found as far northward as Lake Superior; it also occurs in New England, and southward in the Alleghanies and Virginia.

\section{Rock Columbine-Aquilegia Canadensis (Lin.). (PLATE III.) \\ "The graceful columbine, all blushing red, Bends to the earth her crown Of honey-laden bells."}

This graceful flower enlivens us all through the months of May and June by its brilliant blossoms of deep red and golden yellow.

In general outline the Wild Columbine resembles its cultivated sisters of the garden, but is more light and airy in habit. The plant throws up many tall slender stalks, furnished with leafy bracts, from which spring other light stems terminated by little pedicels, each bearing a large drooping flower and bud, which open in succession.

The flower consists of five red sepals and five red petals; the latter are hollowed, trumpet-like at the mouth; ascending they form narrow tubes, which are terminated by little round knobs filled with honey. The delicate thready pedicel on which the blossom hangs causes it to droop down and thus throw up the honey-bearing tubes of the petals, the little balls forming a pretty sort of floral coronet at the junction with the stalk.

The unequal and clustered stamens and the five thready styles of the pistil project beyond the hollow mouths of the petals like an elegant golden-fringed tassel; the edges and interior of the petals are also of a bright golden yellow. These gay colors are well contrasted with the deep green of the root-leaves and bracts of the flower-stalks. The bracts are lobed in two or three divisions. The larger leaves are 
placed on long footstalks; each leaf is divided into three leaflets, which are again twice or thrice lobed and unequally notched; the upper surface is smooth and of a dark rich green, the under pale and whitish. As the flowers fade the husky hollow seed pods become erect; the seeds are black and shining.

The Wild Columbine is perennial and very easily cultivated. Its blossoms are eagerly sought out by the bees and humming-birds. On sunny days you may be sure to see the latter hovering over the bright drooping bells, extracting the rich nectar with which they are so bountifully supplied. Those who care for bees and love humming-birds should plant the graceful red-flowered Columbine in their garden borders. Indeed, this elegant ornamental species should find a place in every garden. I have seen a striking effect produced by a number of these flowers grown together.

In its wild state it is often found growing among rocks and surface stones, where it insinuates its roots into the clefts and hollows that are filled with rich vegetable mould; and thus, being often seen adorning the sterile rocks with its bright crown of waving blossoms, it has obtained the name of Rock Columbine.

Painted CuP-Scarlet CuP-Castilleia coccinea (Spreng.).

(PLATE VII.)

"Scarlet tufts

Are glowing in the green like flakes of fire;

The wanderers of the prairie know them well, And call that brilliant flower the Painted Cup."

-Bryant.

This splendidly-colored plant is the glory and ornament of the plain-lands of Canada. The whole plant is a glow of scarlet, varying from pale flame-color to the most vivid 


\section{NATIVE WILD FLOWERS}

vermilion, rivalling in brilliancy of hue the Scarlet Geranium of our gardens.

The Painted Cup owes its gay appearance not to its flowers, which are not very conspicuous at a distance, but to the deeply-cut leafy bracts that enclose them and clothe the stalks, forming at the ends of the flower-branches clustered rosettes.

The flower is a flattened tube bordered with bright red and edged with golden yellow. Stamens four; pistil one, projecting beyond the tube of the calyx; the capsule is many-seeded. The radical or root-leaves are of a dull hoary green, tinged with reddish purple, as also is the stem, which is rough, hairy, and angled. The bracts, or leafy appendages which appear on the lower part of the stalk, are but slightly tinged with scarlet, but the color deepens and brightens towards the middle and summit of the branched stem.

The Scarlet Cup appears in May, along with the White and Red Trilliums, but these early plants are small; the stem is simple, rarely branched, and the color of a deeper red. As the summer advances our gallant soldier-like plant puts on all its bravery of attire. All through the glowing harvest months the open grassy plains and the borders of the cultivated fields are enriched by its glorious colors. In favorable soil the plant attains a height of from two to three feet, throwing out many side branches, terminated by the clustered brilliantly-tinted bracts; some heads are as large as a medium-sized rose. They have been gathered in the corners of the stubble fields on the cultivated plains as late as October; specimens from the prairies are of a deep purplish red.* A not uncommon

*This is Castilleia miniata, Dougl. 
slender variety occurs of a pale buff, and also of a bright lemon color. The American botanists speak of Castilleia coccinea as being addicted to a low wettish soil, but this has not been my experience; if you would find it in its greatest perfection you must seek it on the high dry rolling plains of Rice Lake, Brantford, the Humber to the north of Toronto, Stoney Lake, the neighborhood of Peterboro', and similar localities.

For soil the Scarlet Cup seems to prefer light loam, and evidently courts the sunshine rather than the shade. If it could be prevailed upon to flourish in our garden borders it would be a great acquisition, from its long continuance in flower and its brilliant coloring. The seed is light brown, contained in thinnish capsules, ripe in September. Gray says: "Herbs parasitic on roots," but our brave plant is no parasite but grows freely on open ground. Neither is it found with us in low wettish places; it loves the light and would not flourish in shade. It is essentially a "prairie flower." I have had bright specimens from our North-West and also from Wisconsin and Dakota, U.S.; of a darker red from Manitoba.

These lovely plants, like many others that adorn our Canadian woods and wilds, yearly disappear from our midst, and soon we shall seek them but find them not.

We might say with the poet:

" "Twas pity Nature brought ye forth

Merely to show your worth,

And lose ye quite!

But ye have lovely leaves, where we

May read how soon things have

Their end, though ne'er so brave;

And after they have shown their pride

Like you awhile, they glide

Into the grave."

-Herrick. 


\section{NATIVE WILD FLOWERS}

I do not know if our brave Scarlet Cup of Canada has any floral relationship to an herb known in the Old Country as "Clary," or by its local and descriptive name of "Eyebright." It is an old-fashioned flower sometimes found in cottage gardens. I remember its curiously colored leaves and bracts attracted my notice when first I saw it in a neglected corner of a poor old woman's garden. There were two varieties, one with the dull veiny leaves bordered with purple, as if the leaves had been dipped inţo some logwood dye; the other with a full pink. I forget, in the long lapse of time since I saw the plants, if the flower itself was pretty or partook of the same tint of color as the foliage, but the great marvel consisted in the black oval seeds, not very large, about the size of the seed of the sage. This wonderful seed, Nannie Prime told me, gave the name to the plant "Eye-bright," though, she added, "the learned gardener folk do call it 'Clary.' If any dust or motes, or any bad humors, are in the eye, and one of these seeds be put into the corner of the eye, it will gather it all round itself and clear the precious sight; and this is why folks do give it the name of 'Eye-bright.' Sure, Miss, the Lord gave this little seed for a cure for us poor folk, and no doubt the whole plant is good for other complaints, as many of our harbs be if we did but use them right." We know of no especial healing virtue contained in the seed or leaves of our beautiful Scarlet Cup; but it charms the eye and delights us, and that is God's gift also. There seems to be no actual void, no space unfilled, in God's creation. Something fills up all vacancies, either in vegetable or animal life; unseen organisms, too subtle and too fine to

* Salvic Sclarea of the Sage Family. 


\section{STUDIES OF PLANT LIFE}

become visible to our unassisted vision, have their existence, though we behold them not.

"Father of earth and heaven, all, all are Thine,

The boundless tribes in ocean, air and plain,

And nothing lives, and moves, and breathes in vain.

Thou art their soul, the impulse is divine :

Nature lifts loud to Thee her happy voice,

And calls her caverns to resound Thy praise ;

Thy name is heard amid her pathless ways, And e'en her senseless things in Thee rejoice."

-Jane Roscoe.

Wild Ginger-Asarum Canadense (L.).

This is a singular herbaceous plant, chiefly found in bush-wood and damp, rich meadow-land. The leaves are wide, rounded kidney-form, with deep sinuses. The flower, on a short peduncle, springs from the root-stock and appears below the leaves close to the ground, never more than one to each shoot; it is campanulate with sharp-pointed segments of a deep chocolate color. The floral envelope consists of a calyx, but no corolla; the creeping thick fleshy root-stock is warm, pungent and aromatic. It is a coarse, singular-looking plant, much used in Indian medicine craft.

\section{LadY's Slippers-Moccasin Flowers.}

Among the many rare and beautiful flowers that adorn our native woods and wilds few, if any, can compare with the lovely plants belonging to the Orchis family. Where all are so worthy of notice it is difficult to make a choice; happily there is no rivalry to contend with in the case of our Artist's preferences. We will, however, first treat of the Cypripediums or Lady's Slippers, better known by the name of Moccasin Flowers, a name common in this country 
to all the species. The plants of this family are remarkable alike for the singular beauty of their flowers and the peculiar arrangement of the internal organs. In the Linnæan classification they were included, in common with all the Orchids, among the Gynandria.

Whether we regard these charming flowers for the singularity of their form, the exquisite texture of their tissues, or the delicate blending of their colors, we must acknowledge them to be altogether lovely and worthy of our admiration.

One of the rarest, and at the same time most beautiful and curious, of our native Orchids is the

\section{RAM'S-HEAD ORCHIS-Cypripedium arietinum (R-Br.),}

which has smooth glaucous green leaves and small purplish flowers bearing a close resemblance to a ram's head, with the horns and ears and a tuft of wool on the top of the head. It is seldom over six inches in height; it grows in cold peat bogs, and flowers in June. Associated with it we find our most gorgeous representative of the family, the

\section{Showy Lady's Slipper or Pink-flowered Moccasin}

Plant-Cypripedium spectabile (Swartz).

\section{(PLATE XIII.)}

This grows chiefly in tamarack swamps and near forest creeks, where, in groups of several stems, it displays its pure blossoms among the rank and coarser herbage. The stem rises to the height of from eighteen inches to two feet. The leaves, which are large, ovate, many nerved and plaited, sheathing at the base, clothe the fleshy stem, which terminates in a single sharp-pointed bract above the flower. The flowers are terminal and generally solitary, although 


\section{STUDIES OF PLANT LIFE}

old and strong plants will occasionally bear two or even three blossoms on one stem. The unfolded buds of this species are most beautiful, having the appearance of slightly flattened globes of delicately-tinted rice-paper.

The large sac-like inflated lip is slightly depressed in front, tinged with rosy pink, and striped. The pale thin petals and sepals, two of each, are whitish at first, but turn brown when the flower is more advanced towards maturity. The sepals may be distinguished from the petals, the former being longer than the latter and united at the back of the flower. The column on which the stamens are placed is three-lobed; the two anthers are placed one on either side, under the two lobes; the central lobe is sterile, thick, fleshy, and bent down, somewhat blunt and heartshaped. The root of the Lady's Slipper is a bundle of white fleshy fibres.

One of the remarkable characteristics of the flowers of this genus, and of many of the natural order to which it belongs, is the singular resemblance the organs of the blossom bear to the face of some animal or insect. Thus the face of an Indian hound may be seen in the Goldenflowered Cypripedium pubescens; that of a sheep or ram, with the horns and ears, in $C$. arictinum; while our "Showy Lady's Slipper" displays the curious face and peering black eyes of an ape.

A rarer species is the

Stemless LAdY's SlipPer-Cypripedium acaule (Ait.).

It differs from the former species by the sac, which is large and of a beautiful rose tint, exquisitely veined with deeper red zigzag lines, not being closed but merely folderl over in front; this is not observable until you examine it 


\section{NATIVE WILD FLOWERS}

closely. The scape rises from between the two large oval leaves, which lie horizontally on the mosses amidst which the plant grows. This species is only one-flowered.

A time will come when these rare productions of our soil will disappear from among us, to be found only in those waste and desolate places where the foot of civilized man can hardly penetrate; where the flowers of the wilderness: flourish, bloom and decay unseen save by the all-seeing eye of Him who adorns the lonely places of the earth, filling them with beauty and fragrance.

For whom are these solitary objects of beauty reserved? Shall we say, with Milton:

"Thousands of unseen beings walk this earth,

Both while we wake and while we sleep-

And think, though man were none,

That earth would want spectators, God want praise?"

Yellow LADY's SLIPPERS.-Cypripedium parviflorum (Salisb.) and Cypripedium pubescens (Willd.).

"And golden slippers meet for fairies' feet."

Of the golden-flowered Moccasin flowers we boast of two very beautiful species, C. pubescens (Hairy Moccasin flower) and C. parviflorum (Lesser-flowered Moccasin flower). The larger plant is the more showy; the smaller the more graceful and with a delicate fragrance which is not so strong in the larger flower. The long spirally twisted petals and sepals, of a purplish brown color sometimes tinted and veined with red, give this smaller flower a very elegant appearance, though the rich golden hue of the larger is more striking to the eye.

C. parviflorum affects the moist soil of wet grassy meadows and swamps, while the larger plant loves the open plain lands among shrubs and tall grasses. In the 


\section{STUDIES OF PLANT LIFE}

month of June, when it may be seen beside the gay Painted Cup (Castilleia coccinea), the Blue Lupine (L. perennis), the larger White Trillium, and other lovely wild flowers, it forms a charming contrast to their various colors and no less varied forms.

The stem of the larger Moccasin flower is thick and leafy, each many-nerved leaf sheathing the flowers before they open. The flowers are from one to three in number, bent forward, drooping gracefully downwards. The golden sac-like lip is elegantly striped and spotted with ruby red; the twisted narrow petals and sepals, two in number of each kind, are of a pale fawn color, sometimes reined and lined with a deeper shade of brown.

\section{SHowy ORCHIS-Orchis spectabilis (L.).}

\section{(PLATE VII.)}

" Full many a gem of purest ray serene

The dark, unfathomed caves of ocean bear; Full many a flower is born to blush unseen,

And waste its sweetness on the desert air."

-Gray.

Deep hidden in the damp recesses of the leafy woods, many a rare and precious flower of the Orchis family blooms, flourishes, and decays unseen by human eye, unsought by human hand, until some curious flower-loving botanist plunges amid the rank, tangled vegetation and brings its beauties to the light. One of these lovely natives of our Canadian forests is known as Orchis spectabilis (Beautiful Orchis, or Showy Orchis). This pretty plant is not, indeed, of very rare occurrence; its locality is rich maple and beechen woods in eastern Canada. The color of the flower is white, shaded, and spotted with pink or purplish lilac; the corolla is what is termed ringent or 
gaping, the upper petals and sepals arching over the waved lower petal. The scape is smooth and fleshy, terminating in a loosely-flowered and many-bracted spike; the bracts are dark-green, pointed, and leaf-like; the root a bundle of - round white fibres; the leaves, two in number, are large, blunt, oblong, shining, smooth, and oily, from three to five inches long, one larger and more pointed than the other. The flowering time of the species is May and June. The exquisite cellular tissues of many of our flowers of this order delight the eye and give an appearance of great delicacy and grace to the blossoms. In this charming species the contrast between the lilac purple color of the arching petals and sepals and the almost pellucid lower lip, or somewhat broadly-lobed under petal, is very charming. The large shining leaves lie close to the ground when the plant is in flower. Transplanted to gardens the Showy Orchis rarely survives the second season of removal from the forest shade. It will not grow freely exposed to cold wind or glaring sunlight. It loves moist heat; the conservatory would probably suit it, and it would be worth a trial there, or in the grove or wilderness, or at the root of a large tree near water.

\section{Wild Garlic-Wild Leek-Allium tricoccum (Ait.).}

As soon as the warm rays of early spring sunbeams have melted the snow in the woods we see the bright closelyfolded and pointed leaves of the Wild Garlic, or Wild Leek, as it is commonly called, piercing through the carpet of dead leaves that thickly covers over the rich black mould, the refuse of many years of former decayed foliage. The cattle, that have been for many months deprived of green food, eagerly avail themselves of the first appearance 
of the succulent and welcome leaves of the Garlic. The milk of the cows becomes so strongly flavored with the disagreeable odor of the oily vegetable that the milk and butter are rejected, and can only be used by persons who are indifferent to the nature of their food; the generality of people turn away with a feeling of disgust from leeky butter and leeky milk. It is, however, a consolation to the thrifty farmer to know that, like many other evils, it has its palliative. The cows and oxen, that have been brought low in flesh and strength during the long, hard winter, are speedily restored to health by feasting upon this otherwise objectionable food.

It is a pleasant plant to the eye, the rich verdure of the broad succulent leaves springing so freshly where all was barren and unsightly; and, later in the season, the tall heads of pretty pale blossoms are not without attraction, though not nice to place in a bouquet of sweeter flowers.

Before so many extensive tracts of forest had been cut down the Wild Garlic was to be found in all beech and maple woods. But it is becoming very rare, and one hears no more complaints of leeky milk and butter.

\section{PhLox-Phlox divaricata (L.).}

We have in Canada several species of this family, and all are worthy of cultivation. Phlox divaricata is found on dry grassy wastes by forest roads, in shady spots. It is a plant of slender growth, about twelve or eighteen inches high, with slender lanceolate pointed leaves somewhat clasping the stem; flowers in a flat spreading head terminal on the slightly-stalked branches; corolla salver-shaped, primrose-like; calyx with slender pointed sepals; color of the petals pale lilac, scalloped at the edges. It is an elegant 
species. A small variety of this beautiful flower has also been found in low meadows near the Ottawa river, growing in great profusion in some of the north-eastern townships, where its beautiful bluish flowers formed an attractive feature in the landscape.

A gentleman who had an especial love for the beauties of nature was much struck with the beauty of this very lovely flower, and brought home some roots; the plant was then in full bloom. They continued to flourish till the following spring, when they disappeared entirely. The leaves were of a full rich glossy green, delicately fringed with silky purplish hairs; fiowers not so large as the $P$. divaricata found here; heads loose on long footstalks springing from between the slightly-clasping leaves; roots white, fibrous.

A charming little dwarf Phlox is that known by the gardeners as Moss Pink, or Lake Erie Moss. The slender pointed grassy-looking foliage and abundant pink flowers, together with its low tufted growth and hardy character, make it most valuable as an edging for flower beds. It comes early and remains for some time in bloom, and even when the blossoms have faded the bright cheerful verdure that remains has a good effect as a pretty edging to the beds. It grows in large cushion-like plots when not used as an edging for borders.

\section{GOLD THREAD-Coptis trifolia (Salisb.).}

In the deep shady forest we are attracted by the bright glossy thrice-parted (trifoliate) leaves of this pretty plant. In early spring its delicate white starry flowers, on upright slender footstalks, appear, just peeping above the mosses among which it delights to grow. The modest pearlywhite star-shaped blossoms contrast well with the dark evergreen shining leaves and orange thready rootlets that 


\section{STUDIES OF PLANT LIFE}

may be seen among the light feathery mosses, hardly concealed, for they are barely covered by the mould in which they grow. The orange fibrous roots and rootlets are intensely bitter, and are much used by the old settlers as tonic remedies against weakness in children when brought low by fever and ague; more especially is it used as a wash for sore ulcerated mouths, as thrush in young infants. The Indian women use it for their little ones in case of sore mouth and sore gums in teething. I once saw the small evergreen leaves of the Gold Thread applied to a very different purpose-that of trimming evening dresses of clear white muslin-and as the heat of the room had little effect on them they looked fresh and singularly ornamental on the young ladies who had so tastefully arranged the leaves on their simple white dresses.

I have noticed the term "Gold Thread" applied lately to one of the species of Dodder, that singular parasite, but it was by a person apparently unacquainted with our elegant little forest evergreen Coptis trifolia.

\section{BUNCH-BERRY-SqUAW-BERRY-Cornus Canadensis (Lin.).}

This elegant and attractive little plant is met with most commonly in beds beneath the shade of evergreens, hemlocks and spruces; it multiplies by its creeping rootstock as well as by the drupe-like berry. Its popular name in the backwoods is the Squaw-berry, and also Bunch-berry. It is a truly lovely little plant-a perfect forest gem.

In height our tiny Dogwood rarely exceeds four or six inches; the stem is leafy, the upper leaves forming a whorl round the flowers, which are enclosed by the white corollalike involucre; the latter is more conspicuous than the tiny terminal umbel of little flowers with their dark anthers. 


\section{NATIVE WILD FLOWERS}

The flowers are succeeded by small round berries, which become brilliantly scarlet by the end of the summer, appearing like a bright red coral ring surrounded by the whorl of dark green somewhat pointed veiny leaves.

From its love of shady damp soil this little plant would grow under cultivation if suitable localities were selected in shrubberies, among evergreens, and in rock-work not much exposed to the sun. This low Cornel is very ornamental both in flower and fruit. The berries are sweet but insipid. The Indian women and children eat them and say, "Good to eat for Indian." The taste of the Indian is so simple and uncultivated that he will eat any fruit or vegetable that is innocuous, apparently indifferent to its flavor.

The poor squaw gathers her handful of berries and goes her way contented with her forest fare, from which the more luxurious children of civilization would turn away with contempt, or admire their beauty, possibly, and then cast them away as worthless. Few indeed think of the lessons that may be learned even from the humblest forest flower, speaking to their hearts of the loving care of the great Creator, who provideth alike for all His creatures. $\mathrm{He}$ openeth His hand and filleth all things living with plenteousness.

There are, among other species of the Dogwood family that might be enumerated as indigenous to this western part of Canada, some with blue berries, some with white, some with red, and others with dark steel-colored fruit. The dwarf Cornel ( $C$. Canadensis) is the smallest species; the rough, bushy round-leaved $C$. circinata the second; $C$. florida. the largest: all are tonics, and bitter; some are used in medicine, others in dyeing, by the natives. The berries of several species are largely sought for as food by the wild 
ducks that haunt the borders of marshes and lake shores where these shrubs abound.

The Cornel seems to have a wide geographical range, it being found not only in the Eastern States of North America, but in the colder parts of Canada, westerly and northerly, and extending even to the borders of the Arctic Zone. I have before me a specimen of a closely allied species from North Cape, Norway, which was gathered by a friend among the dark evergreen glades of that far-off land. The tiny plant is smaller and has a more pinched and starved look than our more vigorous plant, otherwise there is no apparent difference. The early frosts of Autumn give a pretty purple shade to the surface of the leaves of our little forest Dogwood, but they do not wither, remaining fresh and persistent through the winter beneath the snow.

\section{Twisted STALK-Streptopus roseus (Mx.).}

This is a graceful plant, with pretty pink-spotted bells, belonging to the Lily family. We find it in the forests as well as in open grassy thickets. The stalk is divided into two or three branches, bearing on the underside several pairs of graceful pendent bells on thready twisted footstalks. The tips of the segments are pointed and slightly recurved. The berries are red, round and seeded with several hard bony nutlets. The flower is scentless. The foliage is of a light yellowish green, many nerved, oval and pointed. Associated with this there often may be found in the deep shade of pine woods, as well as in the rich black leaf mould of the hardwood forest, the False Solomon's Seal (Polygonatum biflorum-L.), which has pale greenishtinged bells and large blue berries. The leaves are of a 


\section{NATIVE WILD FLOWERS}

dark bluish green. The stem is simple and bends gracefully. The flowers, notwithstanding the name, are mostly solitary. Our woods hide within their shades many a lovely flower seen only by the Indian hunter and the backwoods lumberer or the axe man; by the former they are noted for some medicinal or healing quality, by the latter they are trodden under foot, while to the uneducated settler whose business it is to clear the forest land of the trees and wild productions of the soil, on which the life-supporting grain and roots are to be sown or planted, these natural beauties have no value or charm, and he says, "Cut them down, why cumber they the ground." In these things he sees not the works of the Creator; they are, in his eyes, "weeds, weeds, weeds, nothing but weeds."

Our Bellworts and Trilliums, Smilacinas and Orchids are among the most interesting and attractive of our native forest flowers, but as the woods are levelled and the soil changed by exposure to the influence of the elements and the introduction of foreign plants, these native beauties disappear, and soon the eye that saw and marked their lovely forms and colors will see them no more.

\section{MAY-APPLE-MANDRAKe-Podophyllum peltatum (L.).}

\section{(PLATE VIII.)}

The Mandrake, or May-apple, is found chiefly in the rich black soil of the forest, where partially clear of underwood; in such localities it forms extensive beds. When the broad umbrella-like leaf first breaks the soil, early in May, it comes up closely folded round the simple fleshy stem, in color of a deep bronze or coppery hue, smooth and shining, but assuming a lighter shade of green as it expands. The blossom appears first as a large round green bud between 
the axils of the two broad peltate, lobed and shining leaves; the first year's leaves are single and smaller, and the young plant is flowerless.

The corolla of the flower consists of from six to nine concave greenish-white thick petals; sepals (or calyx leaves), six; the edges of the petals are generally torn or ragged; the handsome flower, slightly drooping between the two large leaves, gives out a powerful scent, not agreeable if inhaled too closely, but pleasant at a little distance.

The plant increases by buds from the thickly matted fleshy root-stock; the roots form a singular network under the soft vegetable mould, spreading horizontally, at every articulation sending up a pair of fruit-bearing scapes. A single-leafed plant is most probably a seedling of the former year.

The fruit of the May-apple is a large fleshy berry; the outer rind when ripe is yellow, otherwise darkish-green and of a rank, unpleasant flavor; the inner or pulpy part is white, soft, and filled with somewhat bony light-brown seeds. When not over-ripe this pulpy part may be eaten; it is sub-acid and pleasant. The fruit makes a fine preserve with white sugar and when flavored with lemon-peel and ginger, but the outer coat I would not make use of. The fruit is ripe in August, and should be gathered when the first yellow spots on the outer coat indicate ripeness, and laid in a sunny window for a few days.

The medicinal value of the root of this remarkable plant is now so well established that it has superiseded the use of calomel in complaints of the liver with most medical practitioners in this country, but so powerful are its properties that it should never be used by unskilful persons. Ignorant persons have been poisoned by mistaking the leaves for those of the Marsh Marigold (Caltha palustris) 


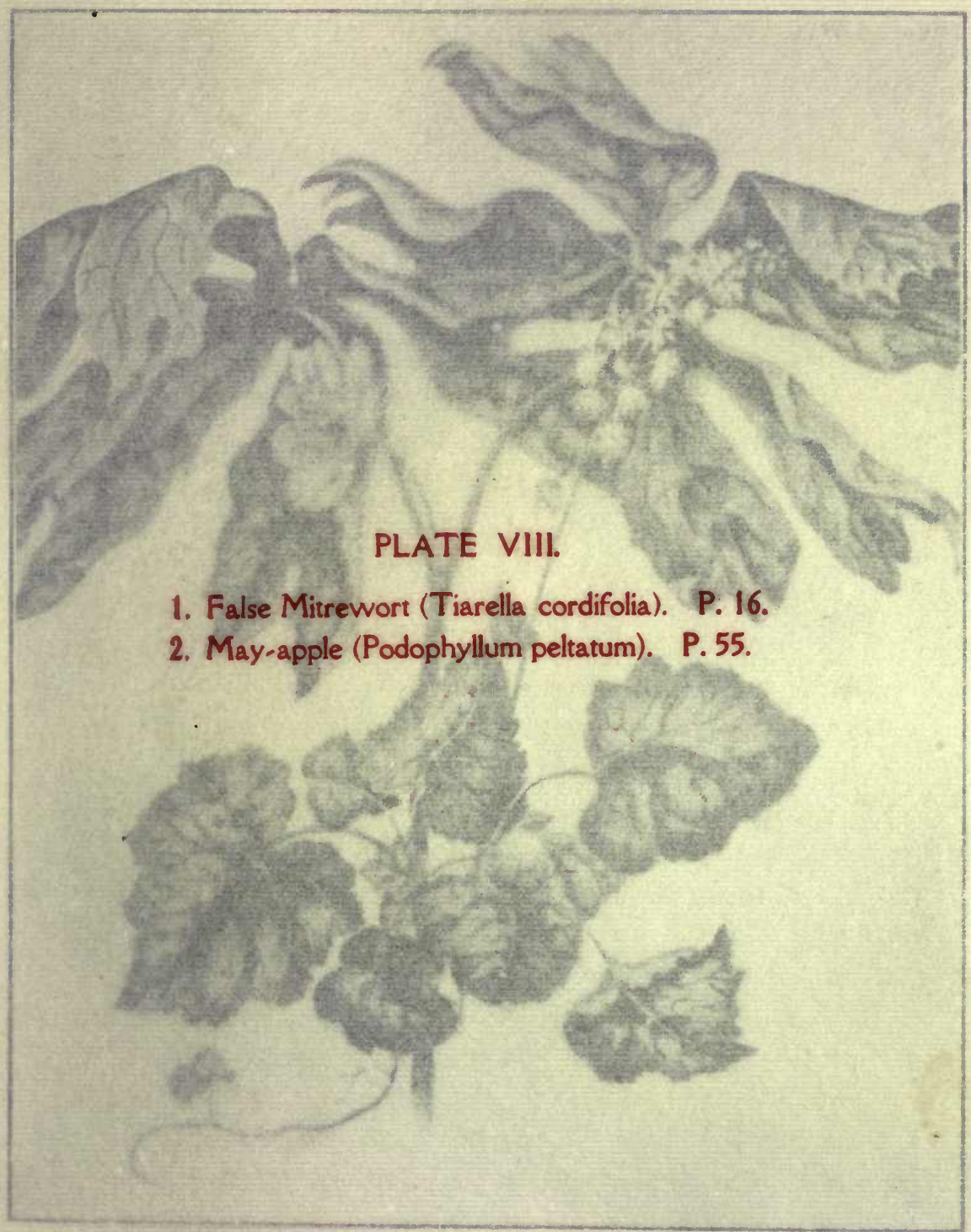




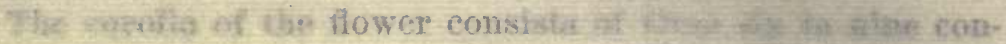

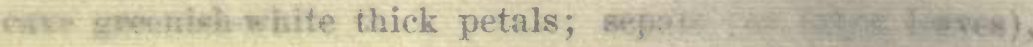

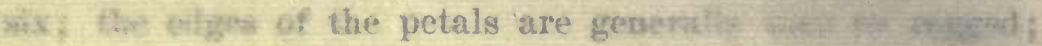

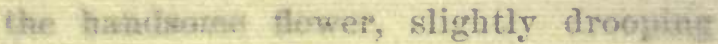
lawer leatrs, gives out a powerful scent inhaled tor closely, but pleasant at a litis

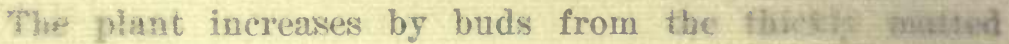
feshy root-stock; the roots form a singular netwon abder the soft vegetable mould, spreading horizontally, as ivery articnlation sending dup a pair of fruit-bearing seagess. A single-leafed plant is most probaliby a seedling of the tomber year.

The fruit of the Mar-apple IIIV 3TAJ9

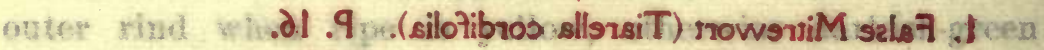

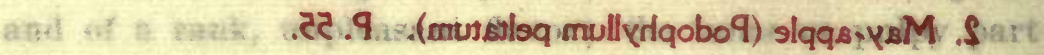

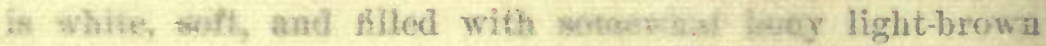

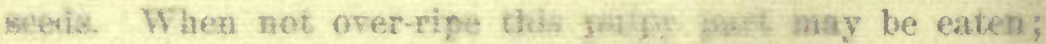

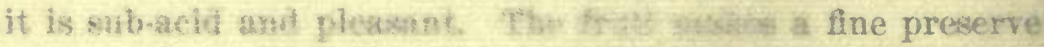

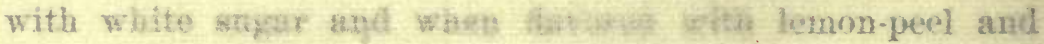
ginger, but the oriter coat $f$ acosiat pat inake use of. The

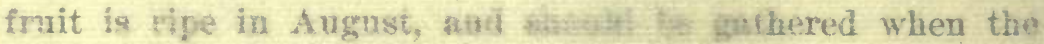
first yellow spots on the onider steat andicate ripeness, and laid in a sumny wiblow for a loc davs.

The moliciual value of the ract of this remarkable plant is now so well estaltilishe? that it hels superweded the use of calomel in complaints of the liver with most medical practitioners in this coubles, bat so powerful are its proporties that it should newer be used by unskilful persons. Igrorant jersons have hern poisoned by mistaking the heavis for those of the March Miturgold (Caltha palustris) 
PLATE VIII.

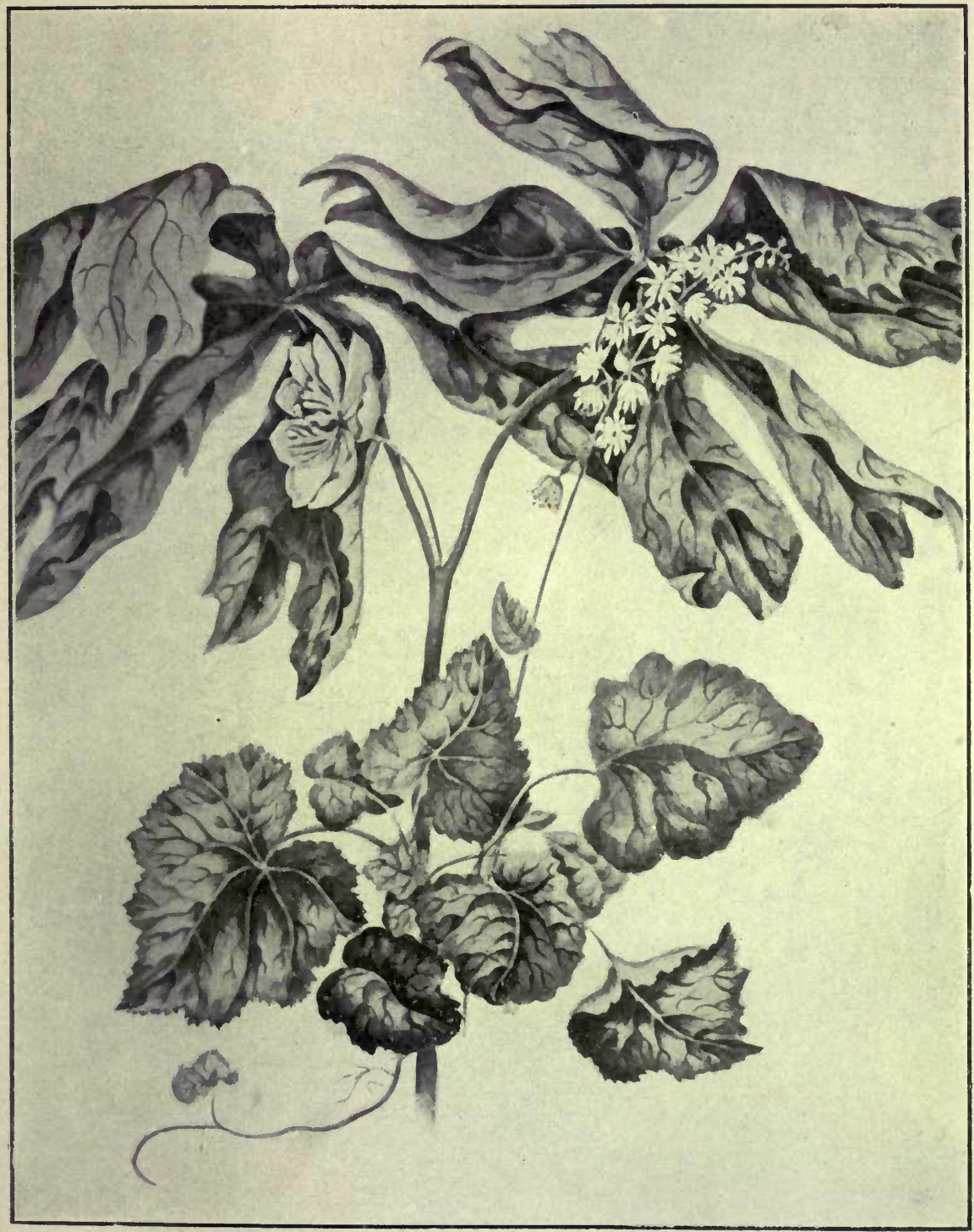





\section{NATIVE WILD FLOWERS}

and using them as a pot herb. A case of this kind occurred some years ago whereby several persons were poisoned. At that time there was no attempt made by the backwoods. settlers to cultivate vegetables, and they made use of many of the wild herbs with very little knowledge of their sanative or injurious qualities.

\section{American Brooklime-Veronica Americana (Schw.).}

(PLATE XVII.)

"Flowers spring up and die ungathered."

-Bryant.

In the language of flowers the blossoms of the Veronica, or Speedwell, are said to mean undying love or constancy, but the blossoms of the Speedwell are fugacious, falling quickly, and therefore, one would say, not a good emblem of the endurance of love or friendship.

Sweet, simple flowers are the wild Veronicas, chiefly inhabiting damp overflowed ground, the borders of weedy ponds and brooks, whence the names of Brooklime and Marsh Speedwell, Water Speedwell, and the like. Some of the species are indeed found mostly growing on dry hills and grassy banks, cheering the eye of the passing traveller with their slender spikes of azure flowers. This species is often known by the pretty name of Forget-me-not, though it is not the true "Forget-me-not," which is Myosotis palustris, also with the rest of its family called "Scorpion-grass," from the small buds, before expansion, having the petals. twisted and forming a small coil at the tips of the branches. The American Brooklime is one of the prettiest of the native Veronicas, and may easily be recognized by its branching spikes of blue flowers and veiny partially heart-shaped leaves. It is but little that we have to say of our pretty 
native wilding, for its delicacy and harmless qualities are all that require notice about it. The traveller passes it by with scarcely a commendatory glance; its fleeting pale blue scentless blossoms, which fall at a touch, scarcely attract the little children when gathering flowers by the wayside brooks. It remains with the true lover of flowers, even if they be only homely weeds, to examine and appreciate the inimitable beauty and wisdom shown in their several parts, each so wisely fitted to perform its part according to the Divine Maker's will.

Wood Geranium-Geranium maculatum (L.).

(PLATE VI.)

There are but few flowers of the Cranesbill family in Canada. The one most worthy of notice is the Wood Geranium. This is a very ornamental plant; its favorite locality is in open grassy thickets, among low bushes, especially those tracts of country known as "oak openings," where it often reaches to the height of from two to three feet, throwing out many branches adorned with deep lilac flowers; the half-opened buds are very lovely. The blossom consists of five petals, obtuse, and slightly indented on their upper margins, and is lined and delicately veined with purple. The calyx consists of five pointed sepals; stamens ten; the anthers are of a reddish brown; styles five, cohering at the top. When the seed is mature these curl up, bearing the ripe brown seed adhering to the base of each one. The common name, Cranesbill, has been derived from the long grooved and stork-like beak composed of the styles. The Greek name of the plant means a crane. The whole plant is more or less beset with silvery hairs. The leaves are divided into about five principal segments; these 


\section{NATIVE WILD FLOWERS}

again are lobed and cut into sharply pointed irregularly sized teeth. The larger hairy root-leaves are often discolored with red and purplish blotches, whence the specific name maculatum (spotted) has been given to this species.

The flower-stem is much branched and is furnished with leafy bracts; the principal flowers are on long stalks, usually three springing from a central branch and again subdividing into smaller branchlets, terminating in buds, mostly in threes, on drooping slender pedicels; as the older and larger blossoms fall off a fresh succession appears on the side branches, furnishing rather smaller but equally beautiful flowers. Gray gives the blooming season of the Cranesbill from April to July, but with us it rarely appears before June and may be seen all through July and August. Besides being very ornamental, our plant possesses virtues which are well-known to the herbalist as powerful astringents, which quality has obtained for it the name of Alum-root among the country people, who use a decoction of the root as a styptic for wounds, and, sweetened, as a gargle for sore throat and ulcerated mouth; it is also given to young children to correct a lax state of the system. Thus our plant is remarkable for its usefulness as well as for its beauty. A low-growing showy species, with large rose-colored flowers and much dissected leaves, may be found on some of the rocky islets in Stoney Lake, Ontario. The slender flower-stem is about six inches in height, springing from a leafy involucre, which is cut and divided into many long and narrow segments; flowers, generally from one to three, terminal on the little bracted footstalks; the seed ressels not so long as in the Wood Geranium.

Besides the above-named we have some smaller species, such as the well-known Herb Robert (G. Robertianum-L.), which is said to have been introduced from Britain but is 


\section{STUDIES OF PLANT LIFE}

by no means uncommon in Canada. It is usually found in half-cleared woodlands and by waysides, attracting the eye by its bright pink flowers and elegantly cut leaves, which become bright red in the fall of the year. This pretty species is notorious for its rank and disagreeable odor, and so it is generally passed by as a weed in spite of its very pretty pink blossoms.

Another small-flowered species, with pale insignificant blossoms, is also common as a weed by roadsides and in open woods; this is G. pusillum, smaller Cranesbill. It also resembles the British plant, but is of too frequent occurrence in remote localities to lead us to suppose it to be otherwise than a native production of the soil; we find it often in very remote places in our forest clearings and road-side wastes.

\section{CHICKWEed WINTERGREEN-STARFLOWER-Trientalis Americana (Pursh).}

(PLATE VI.)

This pretty starry-flowered little plant is remarkable for the occurrence of the number seven in its several parts; it was for some time cherished by botanists of the old school as the representative of the class Heptandria.

The calyx is seven-parted; the divisions of the delicate white corolla also are seven, and the stamens seven. The leaves form a whorl at the upper part of the stem, mostly from five to seven or eight, and are narrow, tapering at both ends, of a delicate light-green, thin in texture, and of a pleasant sub-acid flavor. The star-shaped flowers, few in number, on thread-like stalks, rise from the centre of the whorl of leaves, which thus forms an involucre to the pretty delicate starry flowers. This little plant is frequently found at the roots of trees; it is fond of shade, 


\section{NATIVE WILD FLOWERS}

and in light vegetable mould forms considerable beds; the roots are white, slender and fibrous; it is one of our early May flowers, though, unless the month be warm and genial, it will delay its opening somewhat later. In olden times, when the herbalists gave all kinds of fanciful names to the wild plants, they would have bestowed such a name as "Herbe Innocence" upon our modest little forest flower.

\section{Large Blue Flag-Fleur-De-Luce-Iris versicolor (L.).}

"Lilies of all kinds,

The fleur-de-luce being one."

-Winter's Tale.

This beautiful flower abounds all through Canada and forms one of the ornaments of our low sandy flats, marshy meadows and overflowed lake shores; it delights in wet, muddy soil, and often forms large clumps of verdure in half-dried ponds and similar localities. Early in spring, as soon as the sun has warmed the waters after the melting of the ice, the sharp sword-shaped leaves, escaping from the sheltering sheath that enfolded them, pierce the moist ground and appear in the form of beds of brilliant verdure concealing the swampy soil and pools of stagnant water below. Late in the month of June the bursting buds of rich purple begin to unfold, peeping through the spathe that envelopes them. A few days of sunshine and the graceful petals, so soft and silken in texture, so variable in shades of color, unfold: the three outer ones, reflexed, droop gracefully downwards; while the three innermost, which are of paler tint, sharper and stiffer, stand erect and conceal the stamens and petal-like stigmas, which lie behind them -an arrangement so suitable for the preservation of the fructifying organs of the flower that we cannot fail to 
behold in it the wisdom of the great Creator. The structure of the cellular tissue in most water plants, and the smooth oily surface of their leaves, have also been provided as a means of throwing off the moisture to which their place of growth must necessarily expose them; but for this wise provision, which keeps the surface dry though surrounded with water, the plants would become overcharged with moisture and rot and decay too rapidly to perfect the ripening of their seeds-a process often carried on at the bottom of streams and lakes, as in the case of the Waterlily and other aquatics. Our blue Iris, however, does not follow this rule, being only partly an aquatic; it stands erect and ripens the large bony three-sided seeds in a three-sided membraneous pod. ' The hard seeds of the Iris versicolor have been roasted and used as a substitute for coffee. The root, which is creeping, fleshy and tuberous, is possessed of medicinal qualities.

The name Iris, as applied to this genus, was bestowed upon it by the ancient Greeks-ever remarkable for their appreciation of the beautiful-on account of the rainbow tinted hues displayed in the flowers of many of the species; especially are the prismatic colors shown in the flowers of the large pearly-white garden Iris, a plant of Eastern origin.

The Fleur-de-lis, as it was formerly written, signified whiteness or purity. This was changed to Fleur-de-luce, a corruption of Fleur-de-Louis-the blossoms of the plant having been selected by Louis the Seventh of France as his heraldic bearing in the Holy Wars. The flowers of the Iris have ever been favorites with the poet, the architect, and sculptor, as many a fair specimen wrought in stoue and marble or carved in wood can testify.

The Fleur-de-lis is still the emblem of France. 


\section{NATIVE WILD FLOWERS}

Longfellow's stanzas to the Iris are very characteristic of that graceful flower:

"Beautiful lily_dwelling by still river,

Or solitary mere,

Or where the sluggish meadow brook delivers

Its waters to the weir.

"The wind blow's, and uplifts thy drooping banner,

And around thee throng and run

The rushes, the green yeomen of thy manor-

The outlaws of the sun.

"O fleur-de-luce, bloom on, and let the river

Linger to kiss thy feet;

$\mathrm{O}$ flower of song, bloom on, and make forever

The world more fair and sweet."

Shin-Leaf-Sweet Wintergreen-Pyrola elliptica (Nutt.).

(PLATE XVII.)

"Wandering far in solitary paths where wild flowers blow, There would I bless His name."

- Heber.

The familiar name Wintergreen is applied by the Canadians to many species of dwarf evergreen plants, without any reference to their natural affinities. The beautiful family of Pyrola shares this name, in common with many other charming forest flowers, on account of their evergreen habit.

Every member of this interesting family is worthy of special notice. Elegant in form and coloring, of a delicate fragrance and enduring verdure, they add to their many attractions the merit of being almost the first green things to refresh the eye long wearied by gazing on the dazzling white of the snow for many consecutive months during winter.

As the dissolving crust disappears from the forest beneath 
the kindly influence of the transient sunbeams of early spring, the deep glossy-green shoots of the hardy Pyrola peep forth, not timidly, as if afraid to meet

\section{"The snow and blinding sleet;"}

not shrinking from the chilling blast that too often nips the fair promise of April and May, but boldly and cheerfully braving the worst that the capricious season has in store for such early risers.

All bright and fresh and glossy, our Wintergreens come forth as though they had been perfecting their toilet within the sheltering canopy of their snowy chambers to do honor to the new-born year, just awakening from her icy sleep.

$P$. elliptica forms extensive beds in the forest, the roots creeping with running subterranean shoots, which send up clusters of evergreen leaves, slightly waved and scalloped at the edges, of a deep glossy green and thin in texture.

The name Pyrola is derived from a fancied likeness in the foliage to that of the pear, but this is not very obvious; nevertheless we will not cavil at it, for it is a pretty sounding word, far better than many a one that has been bestowed upon our showy wild flowers in compliment to the person who first brought them into notice.

The pale greenish-white flowers of our Pyrola form a tall terminal raceme; the five round petals are hollow; each blossom set on a slender pedicel, at the base of which is a small pointed bract; the anthers are of a reddish orange color, the stamens ascending in a cluster, while the long style is declined, forming a figure somewhat like the letter J. The seed vessel is ribbed, berry-shaped, slightly flattened and turbinate; when dry, the light chaffy seeds escape through valves at the sides. The dry style in this, and most of the genus, remains persistent on the capsule. 


\section{NATIVE WILD FLOWERS}

The number five prevails in this plant; the calyx is fiveparted; petals five; stamens ten, or twice five; stigma one, but five-rayed, with five knobs or tubercles at the apex; seed-vessel five-celled and five-valved. The flowers are generally from five to ten on the scape.

Most of our Pyrolas are remarkable for the rich fragrance of their flowers, especially $P$. elliptica, and $P$. rotundifolia, together with its variety incarnata.

\section{One-sided Pyrola-P. secunda (L.).}

This little evergreen plant is singular rather than pretty. The flowers, which are greenish white, form a one-sided slender raceme, being all turned to one side of the flowerstem; the style is long and straight, exceeding the stamens and anthers-the latter are very dark, almost dusky black; the stigma, thick and ribbed, forms a turban-shaped green knob in the centre of the flower; stigmas persistent on the capsule. The foliage is dark green, smooth, serrated at the margin of each oval leaf. The leaves are clustered at the base of the flower-stem on foot-stalks, leafing the stem upwards a little. The plant is found in dry woods and on banks, under the shade of trees. The flower is scentless.

Round-leaved Lesser Pyrola-Pyrola rotundifolia (L.), var. incarnata (Gray).

is a far more attractive flower, with a few sweet fragrant pink blossoms and small round or kidney-shaped dark green leaves. Like the sweet violet of Old Country hedgerows, it betrays its presence by its fine perfume, though often deep hidden among the mosses and weeds which are found in the peat-bogs where it grows. We have yet another Pyrola, 
with round green bell-shaped flowers and dark-tipped anthers. This is Pyrola chlorantha (Swartz).

Though we have none of the heaths that clothe the hills and common-lands of Scotland and England, we have a large number of beautiful and highly ornamental as well as useful plants and flowering shrubs belonging to the Natural Order Ericaceæ, which are widely diffused all over the northern and eastern portions of the continent; wherever there exists a similarity in climate, soil and altitude of the land, there we may expect to find members of the same natural orders. Thus we find spread over the northern and eastern portions of this continent plants that are common to northern European countries; we have representatives of many familiar flowers, belonging to such families as the Lily, Rose, Violet, Phlox, Saxifrage, Mint, Dogwood, Pyrola, and Campanula-in fact we cannot enumerate the half of what we recognize in our woodlands and plains. It is true that the eye of the botanist will discover some differences in the species, but in most instances these are so little apparent that a casual observer would not notice them. The Pyrola has its representative flower in England; the Linnxea in Norway. Our pretty Smilacina bifolia, or "Wild Lily of the Valley,"* and our Low Cornel are also found, with many of our native ferns, in that northern land of mountain, flood and forest.

It is pleasant to recognize an old familiar flower-it is like the face of an old friend in a foreign country, bringing back the memory of days lang syne when the flowers that we gathered in our childhood were a joy and a delight to heart and eye.

* See plate IX. 


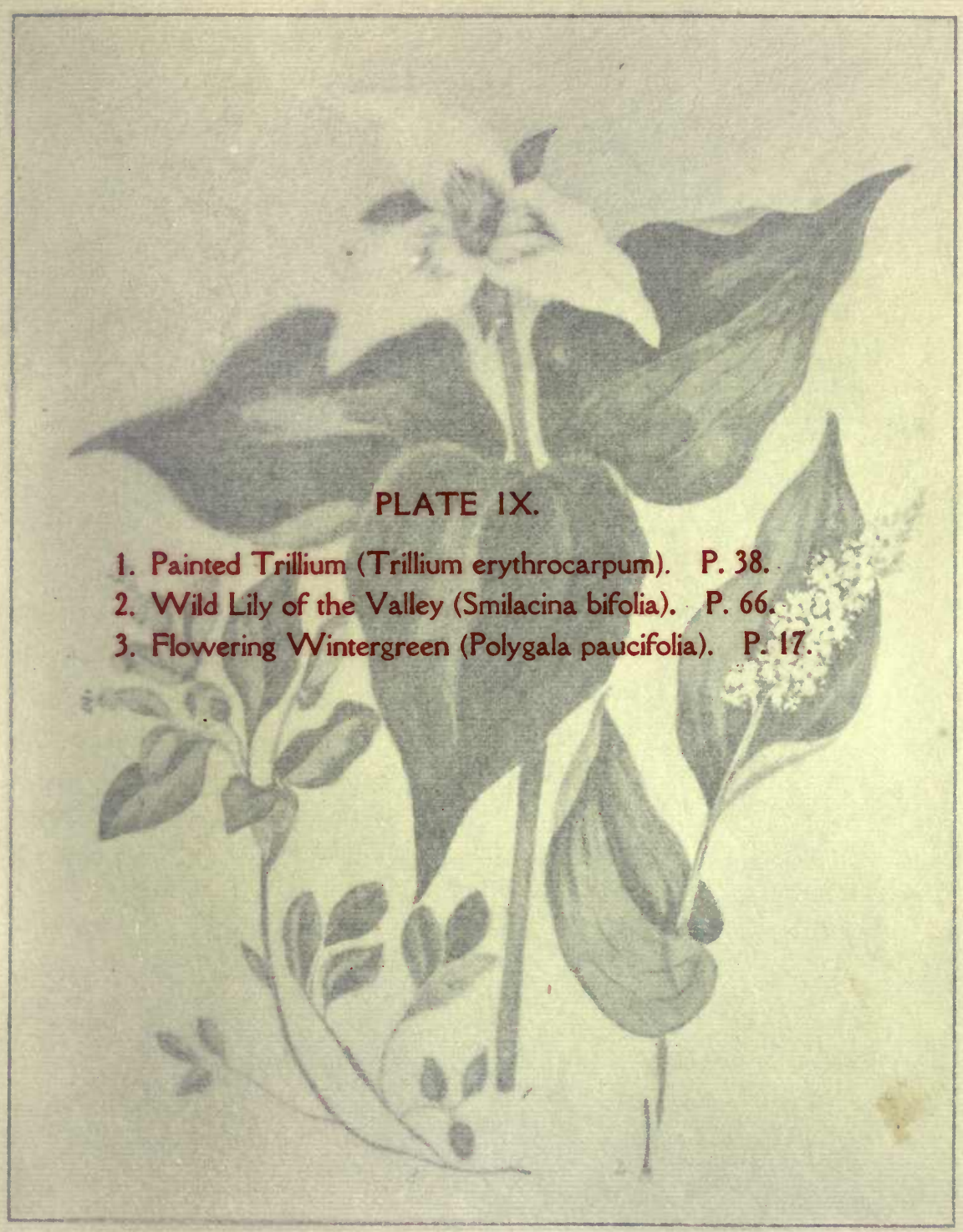




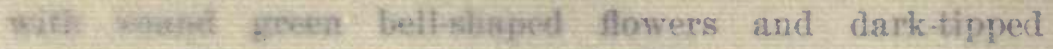
athitirs, This is Pyrola chlowenthe (Swartz).

Thougl: we have none of the hacatin fhat clothe the hills ant crivmon-lands of Scotland and Elygund, we have a large zumber of beautiful and bigisy tomamental as well as usetul plants and flowering sdurates helonging to the Natural Oxder Ericacex, which are Eldety dtafused all over the northern and eastern portions of the continewt; wherever there exists a similarity in etinate, soli and altitude of the land, there we may expect to find menbers of the same natural orders. Thus we find spread over the northern and eastern portions of this continent plants that are common to northern European countries; we have representatives of many farXi ITAJ9ers, belonging to such families as the Lily, Rose, Violet, Phlox, Saxifrage, Mint,

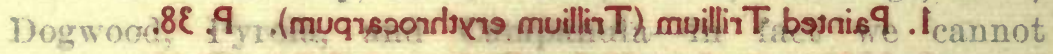
eut:men dd 9 . (silotid snioslime) yollsV ont to vli_l,bliW sllarids

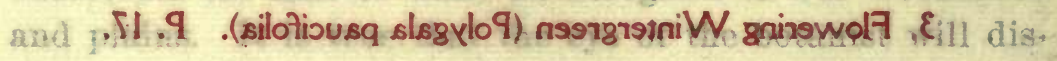
cover some differtiates bat the drecies, but in most instances these are so hitle apranut liat a casual observer would not notice thens. The Pyrolat has its representative flower in Dugland; the Limuet in Norway Our pretty Smilacina bifoika, of "Whld liliy of the Valley," and our Low Cornel are aiso found, with many of our native ferras, in that northern land of motntain, flood and torest.

It - is pleasant to rempulze an old faniliar fower-it is like the face of an old friend in a foreisn conntry, bringing back the memory of diays lang syne when the flowers that we gathered in our chllhood were a joy and $n$ delight to heart and eye.

- See plate $1 \mathrm{X}$. 
PLATE IX.

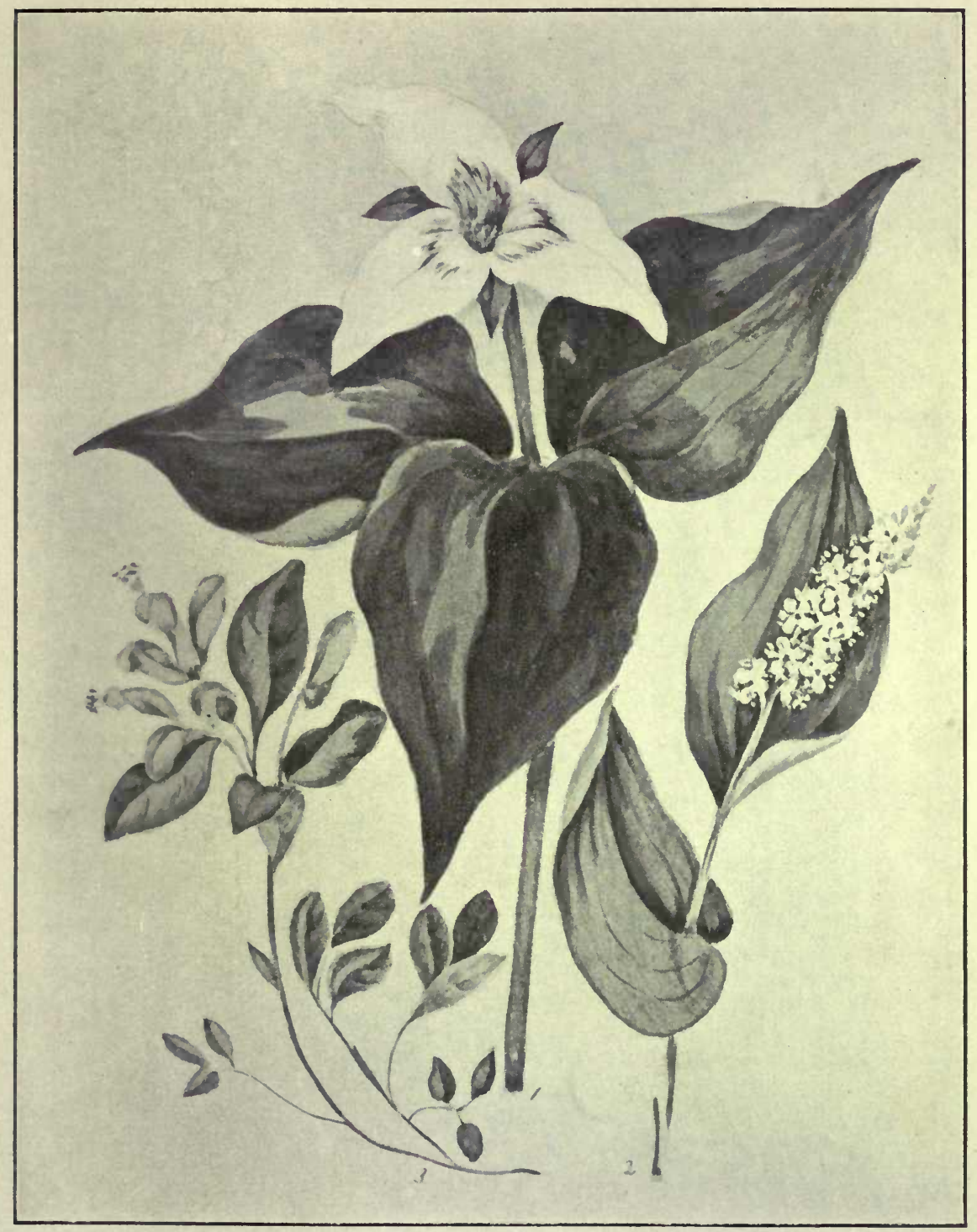





\section{ONe-FLow ered Pyrola-Moneses uniflora (Gray).}

(PLATE XVII.)

This exquisitely scented flower is found only in the shade of the forest, in rich black leaf mould, where, like $P$. elliptica, it forms considerable beds; it is of evergreen habit. The leaves are of a dark green and smooth surface, clustered at the base of short stems which rise from the running root-stock, from the centre of each of which rises one simple scape bearing a gracefully nodding flower; each milk-white petal is elegantly scalloped; the stamens, eight to ten, are set close to the base of the petals; the anthers are of a bright purple-amethyst color; the style straight, with five radiating points at the extremity, forming a perfect mural crown in shape; it is bright green and much exceeds in length the stamens.

The scent of the flower is very fine, resembling in richness that of the hyacinth.

The members of the Pyrola family are, for the most part, found in rich woods, some in low, wet ground, but a few prefer the drier soil of forests; one of these is the exquisitely beautiful evergreen plant known by Canadian settlers as

\section{Prince's Pine-Chimaphila umbellata (Nutt.).}

From root to summit this plant is altogether lovely. The leaves are dark, shining and smooth, evergreen and finely serrated; the stem is of a bright rosy red; the delicately pink-tinted flowers look as if moulded from wax; the anthers are of a bright amethyst-purple, set round the emerald-green turbinated stigma. The flowers are not many, but form a loose corymb springing from the centre of the shining green leaves. There is scarcely a more 


\section{STUDIES OF PLANT LIFE}

attractive native plant than the Chimaphila in our Canadian flora.

The leaves of this beautiful Wintergreen are held in high estimation by the Indian herbalists, who call it Rheumatism Weed (Pipsissewa). It is bitter and aromatic in quality.

\section{LUPINE-Lupinus perennis (L.).}

(PLATE V.)

" Lupine, whose azure eye sparkles with dew."

Those who know the Blue Lupine only as a cultivated flower can form but a poor idea of its beauty in its wild state on the rolling prairies or plain-lands.

On light loamy or sandy soil our gay Lupine may be seen gladdening the wastes and purpling the ground with its long spikes of azure blue, white and purple flowers of many shades.

The Lupine comes in with the larger yellow Moccasin (Cypripedium pubescens); the Trillium grandiflorum; the white Pyrola, Wild Rose (Rosa blanda); Scarlet-cup (Castilleia coccinea) and many others in the flowery month of June; mingling its azure flowers with these, it produces an effect most pleasing to the eye.

The blossoms, like those of all the Pulse tribe to which it belongs, are papilionaceous or winged. The two upper petals or wings are concave, closing over the scythe-shaped keel which encloses the stamens; these are united into a bundle at the base (this arrangement is called by botanists monadelphous). The sheath that conceals the stamens is entire, pointed and varying in color from white to reddishpurple. The flowers are set on short pedicels or flower stalks, forming a close long terminal raceme, the lower flowers opening first. The stem is leafy, erect, downy; the leaves, on longish footstalks, are composed of from seven to 


\section{NATIVE WILD FLOWERS}

nine soft grayish silky leaflets set round the central axis of the stalk in a horizontal circle. The whole plant is soft and velvety in appearance. The pods are long and somewhat broad. The seeds are ivory white when fully ripe, and are the food of squirrels, partridges, field-mice and other wild denizens of the wilderness. The Lupine can be readily grown from seed, and blooms well in our garden plots, abiding with us year after year. The ivory white seeds are often introduced into those pretty, fanciful wreaths frequently exhibited at our township shows, and known as the "Farmer's Wreath," being composed of different varieties of grain and seeds arranged so as to form flowers, leaves, fruits, etc.

Before the plain-lands above Rice Lake were enclosed and cultivated, the extensive grassy flats were brilliant with the azure hues of the Lupine in the months of June and July; but the progress of civilization swept these fair ornaments from the soil. What the lover of the country loses of the beautiful is gained by the farmer in the increase of the useful, and so it must be; but nevertheless we mourn for the beautiful things which gladdened our eyes.

"Oh, wail for the forest, its glories are o'er."

TWINFLOWER-Linncea borealis (Gronov.).

"Nestled at its roots is beauty

Such as blooms not in the glare

Of the broad sun. That delicate forest flower With scented breath, and look so like a smile, Seems, as it issues from the shapeless mould, An emanation from the indwelling life." -Bryant.

"And there Linnæa weaves her rosy wreath."

This delicate and graceful little evergreen is widely diffused through most of the northern countries of Europe and America. It is found within the limits of the Arctic 


\section{STUDIES OF PLANT LIFE}

Circle; in dreary Kamschatka and in snowy Lapland the young girls wreathe their hair with its flexible garlands. In inhospitable Labrador it covers the rocks and mossy roots of pines and birches in lonely shaded glens. It is found in the Scottish Highlands and through all parts of the Northern and Eastern States of America. In all the provinces of our own Canada it may be found in secluded spots. On the rocky islands of the St. Lawrence and on our inland lakes it is particularly abundant; its graceful trailing branches cover the rude rocks and fling a robe of luxuriant vegetation over decaying fallen timber, concealing that which is unseemly with grace and beauty.

"Sweet flower, that in the lonely wood

And tangled forest clothest the rude twisted roots

Of lofty pine and feathery hemlock

With thy flower-decked garland ever green;

Thy modest, drooping rosy bells of fairy lightness

Wave gently to the passing breeze,

Diffusing fragrance:"

This pretty, graceful little plant was named in honor of the great father of botany, the good Linnæus, who chose it more especially as his own flower when he plucked it first in Bothnia, and by his wish it was adopted for the crest of his coat-of-arms.

The little flower has been immortalized by the great botanist. It is said that one of his pupils, aware of his great master's love for the plant, when visiting China, caused a service of fine porcelain to be made and decorated with wreaths of the Linnæa, as a present to Linnæus and as a mark of his grateful remembrance.

At the death of the great naturalist, Cardinal de Noailles erected a cenotaph in his garden to his memory, and planted this little northern flower at its base for the sake of him whose name it bears.*

* See Miss Brightwell's Life of Linnæus. 


\section{NATIVE WILD FLOWERS}

At every joint the Linnæa puts forth white fibrous rootlets, thus increasing and perpetuating the growth of the plant till it forms a tangled mass of leafy branches. The leaves are round, slightly crenate, with a deeper notch at the top, and together with the younger stalks are somewhat hairy. They are placed in opposite pairs, from the centre of each of which rises a slender flower stalk, forking near the summit and bearing a pair of delicate rose-tinted drooping bells, veined with lines of a deeper pink. The throat of the bell is tubular, as in the Honeysuckle, and is thickly beset with silvery woolly hairs. Stamens four, two of them shorter than the others; the corolla is divided near the margin into five pointed segments. Seed vessel a dry and glandular three-celled but one-seeded pod.

If planted for cultivation, the ground should be shaded and somewhat damp. In an artificial rock-work, sufficiently protected from the glare of sunshine and kept moist in hot days, it would grow luxuriantly and throw its evergreen matted branches over and among the stones with pretty effect. The blossoms give out a delicate fragrance, especially at dewfall, the scent being scarcely perceptible during the noontide heat.

Our charming Twinflower is very constant in its habits, being found year after year in the same locality so long as it enjoys the advantages of shade and moisture; it cannot endure exposure to the heat and glare of sunshine, though it will linger as long as it can obtain any shelter.

Thirty years ago I found the Linnoca borealis growing beneath the shade of hemlock trees, among long Sphagnous mosses, on the rocky banks of the Otonabee. Last year, on re-visiting the same spot, I noticed a few dwarfed and starved-looking yellow plants struggling, as it were, for existence, but the evergreens that had sheltered them at their roots were all gone. 
There seems to be a law of mutual dependence among the vegetable tribes, each one ministering to the wants of the others. Thus the shelter afforded by the larger trees to the smaller shrubs and herbs is repaid again to them by the nourishment that the decaying leaves and stems of these latter afford, and by the warmth that they yield to their roots in covering the ground from the winter cold, thus protecting them from injury. Further than this, it is very probable that they appropriate to their own use qualities in the soil or in the air that might prove injurious to the healthy growth of the larger vegetables. That which is taken up by one race of plants is often rejected by others. Yet so beautiful is the arrangement of God's economy in the vegetable world that something gathers up all fragments and nothing is lost-nay, not the minutest particle runs to waste. The farmer practically acknowledges the principle that one kind of vegetable feeds upon that which another rejects, when he adopts a certain routine in cropping his land, for he knows that if he planted grain in constant succession the soil would soon cease to yield its increase, because it would have ceased to afford the food necessary for perfecting the grain; but he sows wheat after roots, as potatoes, turnips and beets, or after pulse, as pease, beans or vetches, for these have taken only certain constituents of the soil, leaving those portions on which the cereals feed unappropriated. Thus silently, unconsciously, and mysteriously do God's creatures administer to one another, working out the will of their Great Creator and obeying His laws while following the instincts of their several natures.

We might follow this inviting subject to a greater length than our limits will admit, but it is time that we dismiss the lovely little Twinflower, hoping that it may sometimes win an admiring glance from readers who may be 


\section{NATIVE WILD FLOWERS}

so fortunate as to meet with its evergreen wreaths and fragrant flowers in its native woods during the leafy month of June, which is its flowering season-though often it may be seen lingering in rocky woods through July, and now and then a few late blossoms will be found in shady ground late in August.

\section{Round-LEAved Sundew-Drosera rotundifolia (L.).}

Two species of this interesting and singular family are common in Canada. One, Drosera rotundifolia, with round leaves beset with stiff glandular hairs of a deep red color, abounds in boggy soil in most parts of the Dominion.

The beauty of this little plant consists in the hairy fringes of the leaves, which exude drops of a clear dew-like fluid; each little leaf seems adorned with a row of liquid gems, beautiful as pearls and glistening in the sunlight like miniature diamonds.

The round red leaves are prolonged into the petiole, or rather the leafstalk is expanded at its edges and terminates in the glandular leaf. The flowers are small, white, sometimes tinged with pink, borne on a slender naked somewhat one-sided scape, which droops a little at the tip. I am not aware of any medicinal or useful qualities of the Sundews, but the eye that sees the beauty set forth in the little dew: gemmed leaf of this lovely plant may behold in it with reverent admiration a work of creative mind surpassing all that man's ingenuity can produce. The jeweller may polish and set the ruby and the diamond in fretted gold, but he cannot make one ruby-tinted leaf of the little Sundew.

A rather narrower-leaved species is Drosera longifolia (L.), which grows abundantly in a peat marsh near Stoney Lake, at a spot known as "Hurricane Point," a rocky cape 
at the rear of which lies a low marshy flat covering several acres of wet ground-a rare garden and nursery for many charming flowering shrubs and exquisite bog-loving plants. A beautiful carpet of white Peat Moss (Sphagnum cymbifolium) is spread over the surface nearly a foot deep; on this we see the graceful low-bush Cranberry trailing its slender branches with their dark green glossy myrtlelike foliage and delicate pink revolute flowers, as well as berries in every stage of progress-the tiny green immature fruit, the golden, the mottled and the deep red ripe berry. How tempting to the hand and eye! There the slender-leaved Sundew mixes its white flowers with the fringed Orchis, sending up from the watery soil its modest flowers in the midst of a bed of the grand blossoms of that rarely constructed plant, the "Pitcher Plant" (Sarracenia purpurea), or, as it is called by some writers, "Side-saddle flower."*

The bog of which I speak abounds in shrubs, among which we see the narrow dark-leaved Sheep-laurel (Kalmia glauca), with its rose-colored flowers; the aromatic SweetGale (Myrica Gale), and Labrador Tea (Ledum latifolium), with its revolute rosemary-like narrow leaves and whitish flowers. Above all for beauty is the White Peat Moss itself, with its soft velvety foliage, varying in shade from pale sea-green or creamy-white to delicate pink and deeper rose. I know of nothing more lovely than are these exquisite Sphagnums; nor are they without their value, for they are much used by the florist and gardener in packing roots and plants for sale.

There are more vegetable treasures to be found in the

* Gray says it is difficult to fancy any resemblance between this flower and a sidesaddle. I venture to suggest that the common name originated from the flap-like extension of the leaf. 


\section{NATIVE WILD FLOWERS}

peat marsh near Hurricane Point than I have noticed. A deer track leads beyond this marsh to Fairy Lake. This lake is like a mountain tarn; it is surrounded by lofty rocks, and is not a mere inlet from Stoney Lake, as it now appears, being encircled on all sides by a stony barrier of rugged rocks, some rising from the water's edge bare and precipitous, or clothed with gray hoary tufts of Cladonias and other lichens and mosses. In the clefts may be found the somewhat rare Hairy Woodsia (Woodsia Ilvensis) and the Rock Polypody ( $P$. vulgare). The last-named is not, indeed, an uncommon adornment to the rocky bluffs and stony islands of our back lakes, where it enlivens the rugged gray rocky surfaces with its bright glossy fronds and golden fruit dots. The rocks decline to the side facing the larger lake, and towards the western corner there is a bed of the White Peat Moss, overshadowed by a forest of that grand fern, Osmunda regalis, worthy of its regal name, for here, among the soft Sphagnums, and towering to the height of five and six feet, it bears above its light green leafage (or should I say frondage?) its rich tufts of cinnamonbrown sporangia. Beneath the Osmundas, and rising above the mosses, the crimson-lipped leaves and large red flowers of the Pitcher Plant (Sarracenia purpurea) may be seen in great perfection.

These are but a few of the attractions of Fairy Lake, for there are flowers and flowering shrubs of many kinds that grow in the wild rocky soil. The beautiful spikes of the rose-blossomed Spirca tomentosa, the Hardhack of the Indians, and the graceful white Spircea salicifolia, Wild Roses, Goldenrods, and Asters, with many others, are scattered round this lovely lakelet, rendering it a place of interest to the botanist and to the pleasure-seeking tourist. 
Pitcher Plant-Soldier's Drinising Cup-Sarracenia

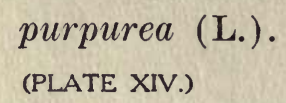

In passing a bed of these most remarkable plants even the most casual observer must be struck by their appearance. Indeed, from root to flower they are in every way worthy of our notice and admiration.

The Pitcher Plant is by no means one of those flowers found only in inaccessible bogs and dense cedar-swamps, as are some of our rare and lovely Orchids. In almost any grassy swamp, at the borders of low-lying lakes and beaver-meadows-often in wet, spongy meadows-it may be found forming large beds of luxuriant growth.

When wet with recent showers, or glistening with dewdrops, the rich crimson veinings of the broadly-scalloped lip of the tubular leaf (which is thickly beset with fine stiff silvery hairs) retain the moisture and shine and glisten in the sunlight.

The root-stock is thick and bears many fibres. The tubular leaves are of a reddish tinge on the outer and convex side, but of a delicate light green within. The texture is soft, smooth and leathery; the base of the leaf at the root is narrow and pipe-stem-like, expanding into a large hollow receptable capable of containing a wine-glassfull of liquid; even in dry seasons this cup is rarely found empty. The hollow form of the leares and the broad ewerlike lips have obtained for the plant its local and widespread names of "Pitcher Plant" and "Soldier's Drinking Cup." This last name I had from a poor old emigrant pensioner who brought me a specimen of the plant from the banks of a half-dried up lake near which he was located, with the remark: "Many a draught of blessed water have we poor soldiers had, when in Egypt, out of the leaves of a plant 


\section{PLATE $X$.}

1. Arrow-head (Sagittaria variabilis). P. 91.

2. Great Lobelia (Lobelia syphilitica). P. 139.

3. Cardinal Flower (Lobelia cardinalis). P. 138. 


\section{purpiaree (L.).}

(PLATE XIV)

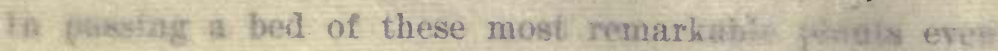
the taest casual obserfer inust be struck by dipif appearsunt- lateded, from root to flower they are is enery way veothy of our notice and admiration.

The Piteher Plant is by no means one of those flowers frmud ondy in inaccessible bogs and dense cedar-swamps, as aze some of our rare and lovely Orchids. In almost any graway. swamp, at the borders of low-lying lakes and bearer-meadows - often in wet, spongy meadows-it may be found forming large beds of luxuriant growth.

When wet with recent showers, or glistening with dewdrops, the rich crimson $X$ ITA 19 the broadly-scalloped lip of the tubnlar leaf (XIA thichly beset with fine stifi silvery 19,9 .(ailidsinsv sinstrigs2) bosd-wond A tine and

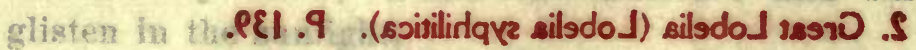

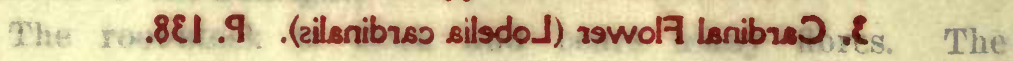

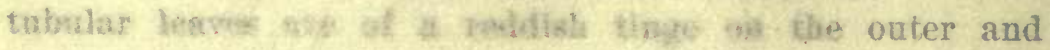

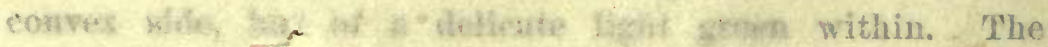

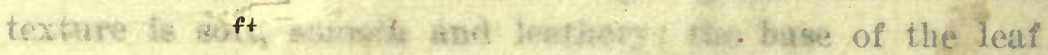

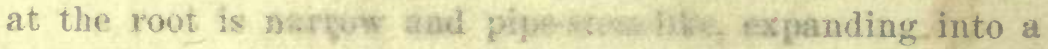
large hollow receptable eapable of crobsaing a wine-glassfull of liquid; even in dry seasecis alsts oup is rarely found empty. The hollow form of the fworn and the broad ewerlike lips have obtained for the ritank its local and widespread names of "Pitcher Plant" atol "soldier's Drinking Cap." This last name I hod tros a foor old emigrant yeusioner who brought me a speednezt of the plant from the banks of a belf-dried up lake near of it as he was loceted, with the renaik. "Nany a draught of Ntesped water have we poor soldiere bat, when in Egypt, one of the leaveg of a plant 
plate $\mathrm{X}$

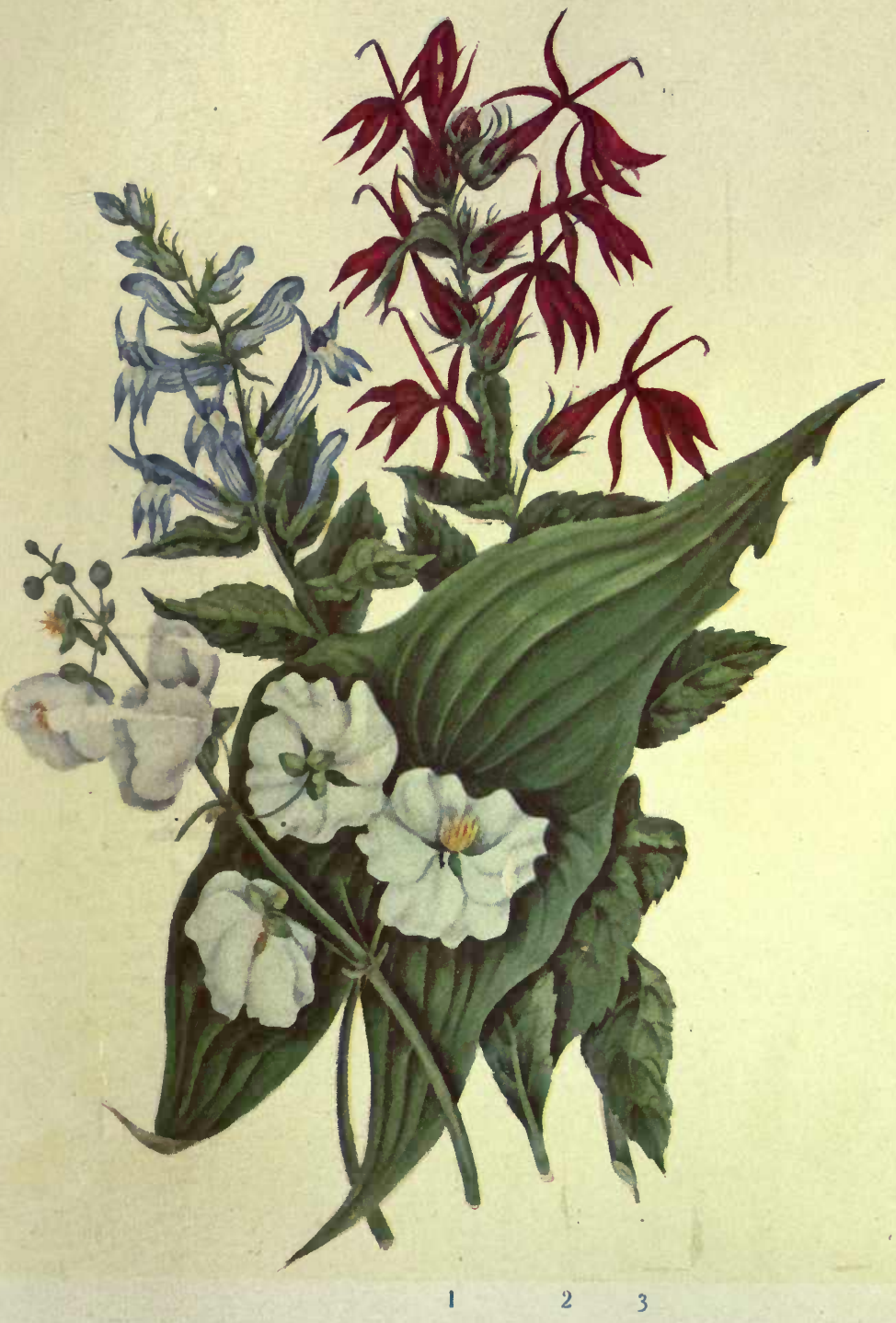



like this, and we used to call it the 'Soldier's Drinking Cup.'"

Most probably the plant that afforded the "blessed water" to the poor thirsty soldiers was the Nepenthes distillatoria, which plant is found in Egypt and other parts of Africa. Perhaps there are but few among the inhabitants of this well-watered country that have as fully appreciated the value of the Pitcher Plant as did our poor uneducated Irish pensioner, who said that he always thought that God in His goodness had created the plant to give drink to such as were athirst on a hot and toilsome march; and so he looked with gratitude and admiration on its representative in Canada.

Along the inner portion of the leaf there is a wing or flap which adds to its curious appearance. The evident use of this appendage is to contract the inner side of the leaf and to produce a corresponding rounding of the outer portion, which is thus thrown backwards, enabling the moisture more readily to fill the cup and to be there retained. Quantities of small flies, beetles and other insects enter the pitcher, possibly for shelter, but are unable to get out again owing to the reflexed bristly hairs that line the upper part of the tube and lip, and thus find a watery grave in the moisture that fills the hollow below.

The tall stately blossom of the Pitcher Plant is not less worthy of our attention than the curiously-formed leaves. The smooth round simple scape rises from the centre of the plant to the height of eighteen inches or two feet. The flower is single and terminal, composed of five sepals, with three little bracts; five blunt broad petals of a dull purplish red color, but sometimes red and light-yellowish green; and in one variety the petals are mostly of a palegreen hue and there is an absence of the crimson veins in the leafage. The petals are incurved or bent downwards 
toward the centre. The stamens are numerous. The ovary is five-celled, and the style is expanded at the summit into a five-angled five-rayed umbrella-like scalloped mantle, which conceals beneath it five delicate rays, each terminating in a little hooked stigma. The capsule, or seed-ressel, is fivecelled and five-valved; seeds numerous.

I have been more minute in the description of this interesting plant because much of its peculiar organization is hidden from the eye and cannot even be recognized in a drawing, unless it be a strictly botanical one with all its interior parts dissected; and also because the Pitcher Plant has lately attracted much attention by its reputed medicinal qualities in cases of smallpox, that loathsome scourge of the human race. A decoction from the root of this plant has been said to lessen all the more violent symptoms of the disorder. If this be really so its use and application should be widely known; fortunately, the remedy would be within the reach of everyone; like many of our sanative herbs, it is to be found without difficulty, and being so remarkable in its appearance, can never be mistaken by the most ignorant of our country herbalists for any injurious substitute.*

\section{Wild Orange Lily-Lilium Philadelphicum (Lin.).} (PLATE XIII.)

"Consider the lilies of the field, how they grow; they toil not, neither do they spin; and yet I say unto you, that Solomon in all his glory was not arrayed like one of these."

The word lily is said to be derived from a Celtic word, $l i$, which signifies whiteness; also from the Greek lirion. Probably the stately Lily of the garden, Lilium candidum,

* I regret to be compelled to say that later experience has dispelled belief in the virtue of the Pitcher Plant, no such good results having been obtained from repeated. trials in cases of that direful disease, smallpox. 


\section{NATIVE WILD FLOWERS}

was the flower to which the name was first given, from its ivory whiteness and the exquisite polish of its petals. However that may be, the name lily is ever associated in our minds with grace and purity, and reminds us of the Saviour of men, who spake of the lilies of the field, how they grew and flourished beneath the care of Him who clothed them in robes of beauty more gorgeous than the kingly garments of Royal Solomon.

Sir James Smith, one of the most celebrated of English botanists, suggests that the flower alluded to by our Lord may have been Amaryllis lutea, or the Golden Lily of Palestine, the bright yellow blossoms of which abound in the fields of Judrea and at that moment probably caught His eye, their glowing color aptly illustrating the subject on which He was about to speak.

The Lily family has a wide geographical range, being found in some form in every clime. There are lilies that bloom within the cold influence of the Frigid Zone, as well as the more brilliant species that glow beneath the blazing suns of the equator in Africa and southern Asia.

Dr. Richardson mentions, in his list of Arctic plants, Lilium Philadelphicum, our own gorgeous Orange (or rather scarlet-spotted) Lily. He remarks that it is called by the Esquimaux "Mouse-root," from the fact that it is much sought after by the field-mice, which feed upon the root. The porcupine also digs for it in the sandy soil in which it delights to grow.

In Kamschatka the Lilium pomponium is used by the natives as an article of food, and in Muscovy the white Narcissus is roasted as a substitute for bread.

The healing qualities of the large white Lily roots and leaves, when applied in the form of a poultice to sores and boils, are well known. Thus are beauty and usefulness. united in this most attractive plant. 
We find the Orange Lily most frequently growing on open plain-lands where the soil is sandy loam. In partially-shaded grassy thickets in oak-openings, in the months of June and July, it may be seen mixed with the azure blue Lupine (Lupinus perennis), the golden-flowered Moccasin (Cypripedium pubescens), the large sweetscented Wintergreen (Pyrola elliptica), and other charming summer flowers. Among these our gay and gorgeous Lily stands conspicuous.

The stem is from eighteen inches to two feet high. The leaves are narrow, pointed, and of a dark green color, growing in whorls at intervals round the stem. The flowers are from one to three-large open bells, of a rich orange scarlet within, spotted with purplish brown or black. The outer surface of the petals is pale orange; anthers six, on long filaments; pollen of a brick red or brown color; stigma three-lobed.

Many flowers increase in beauty of color and size under cultivation in our gardens, but our glorious Lily can hardly be seen to greater advantage than when growing wild on the open plains and prairies under the bright skies of its native wilderness.

HAREBELL-Campanula rotundifolia (Lin.).

(PLATE XIII.)

"With drooping bells of purest blue

Thou didst attract my childish view,

Almost resembling

The azure butterflies that flew,

Where 'mid the heath thy blossoms grew,

So lightly trembling."

The writer of the above charming lines has also called the Harebell "the Flower of Memory," and truly the sight of these fair flowers, when found in lonely spots in Canada, 


\section{NATIVE WILD FLOWERS}

has carried one back in thought to the wild heathery moors or sylvan lanes of the Mother Country.

"I think upon the heathery hills

I ae hae lo'ed sae dearly ;

I think upon the wimpling burn

That wandered by sae clearly."

But sylvan wooded lanes and heathery moorlands are not features of our Canadian scenery, and if we would find the Harebell we must look for it on the dry gravelly banks of lakes and rivers, or on rocky islets, for these are its haunts in Canada.

Although in color and shape of the blossom the Canadian flower resembles the British one, and is considered by botanists to be the same species, it is less fragile, the flower stems being stouter and the footstalk or pedicel stiffer and less pendulous; the root-leaves, which are not very conspicuous during its flowering season, are round heartshaped. Those of the flower-stem are numerous, narrow, and pointed. This pretty flower is variable in color and foliage. Its general flowering season is July and August.

The corolla is bell-shaped or campanulate, five-cleft; calyx lobes awl-shaped, persistent on the seed vessel; stamens five; style one; stigmas two; seed-vessel several celled and many seeded; in height the plant varies from a few inches to a foot; the number of flowers vary from a few to many.

We have three common species in Canada: the present one, Campanula Americana (Lin.), a large, handsome species found in Western Canada; and $C$. aparinoides (Pursh), the Rough-stemmed Bellflower, which is found in thickets and swamps. The latter is of a climbing or rather clinging habit, the weak slender stem, many-branched, laying hold of the grasses and low shrubs that surround 
it for support, which its rough teeth enable it to do very effectually; in habit it resembles the smaller Galium, or Lady's Bed-straw. The graceful bell-shaped flowers are of a delicate lavender color. The leaves of this species are narrow-linear, rough with minutely-toothed bristles; the flowers are few and fade very quickly. The name Campanula is a diminutive from the Italian campana, a bell.

The Harebell has often formed the theme of our modern poets, as illustrative of grace and lightness. In "The Lady of the Lake" we have this pretty couplet, when describing Ellen:

" E'en the light harebell raised its head Elastic from her airy tread."

YELLOW-FLOWERED WOOD-SORREL-Oxalis stricta (L.).

This delicate little flower may be found occasionally by the wayside, but is oftener seen among the herbage near the borders of cultivated fields. The trifoliate leaves are terminal on longish footstalks, thin in texture, and of a pleasant acid taste. At sunset, like the clover and other trefoils, it droops and folds its leaflets together to sleep, for some plants rest as in sleep. This Wood-sorrel is somewhat branching and bushy; the pale yellow blossoms are on long stalks, fading very soon. There is also another species-Oxalis Acetosella (L.) - white with purple veinings, a lovely delicate thing of great beauty, which is found on damp mossy banks at the edge of low pastures. It has been asserted by some persons that the Wood-sorrel is the Irish Shamrock, the emblem of the Holy Trinity; but it is more likely, if St. Patrick really used any plant as a simile, that he took the familiar golden-blossomed trefoil Yellow Clover, which is the Shamrock which grows so abundantly in Ireland by waysides.* The Wood-sorrel is of rarer occurrence and of less familiar appearance.

* St. Patrick is said to have plucked the tiny leaves to explain how one could be three. 


\section{NATIVE WILD FLOWERS}

Cistus-Roci-Rose-Helianthemum Canadense (Michx.).

We find the yellow Cistus growing on gravelly hills and sunny banks. It is a pretty delicate-flowered plant of slender upright growth and hoary foliage, beset with silverygray hairs. The flowers, rarely more than two opening at a time, are about an inch wide; the petals slightly notched at the upper edge, of a pale brimstone color; the many stamens and anthers reddish-orange. The flowers open at sunrise but fall before night; they are so slight in texture that the least touch affects them. There is a peculiarity in this plant that is very singular, the tendency to produce an abundance of abortive flowers along the lower portion of the stem. These never open, and give a scaly look to the plant. The Cistus is also known by the name of "Frost Plant"; this name may have been given to it from the hoary appearance of the leaves, though a less obvious cause has been assigned for the name. It is said that icecrystals are formed on the bark in the autumnal frosts; but most likely some crystallized substance from the juices of the plant has been mistaken for ice.

\section{Yellow Flax-Wild Flax-Linum sulcatum (Riddell).}

This is a delicate little plant, mostly found on dry sunny banks during the hot summer months. The blossoms resemble the common blue Flax, but are smaller; the narrow leaves are harder in texture and the plant not more than one foot in height; the flower falls very soon.* I do not know if the stem possesses the thready flax fibre of the cultivated species; its only recommendation is the pretty pale yellow blossom.

* This is so marked that after picking many and finding the flower fallen before I got home, I had to take my materials and sit on the side of the bank and sketch it as it grew. A. D. C. 
Canadian Balsam-Impatiens fulva (Nutt.).

Our Wild Balsam is a singularly gay plant with its profusion of orange-colored spotted flowers, light foliage and semi-transparent stems. The butterflies seem to take delight in hovering over the bright blossoms, and the humming-birds may be seen on sunny days with outstretched beaks and wings winnowing the air as they balance their tiny bodies while extracting sweets or insects from the curiously-hooded flowers. In the New England States it is known as the Humming-bird Flower, but it has other pretty descriptive names, Jewel Weed, Speckled Jewel, and Touch-me-not. This last alludes to the sensitive nature of the slender seed-pods, which burst at a slight touch, rolling themselves into pretty rings and shedding abroad the seed.

The flowers hang lightly, drooping on very slender thready stalks; when open the outer sepal of the colored calyx forms a hooded cap which reminds one of an old jester's cap and bells. It is only in the single-flowered Balsam under cultivation that we see the curious hood with its horn-like nectary; but the elastic seed-pod is, like the wild species, equally sensitive if touched. A strong coloring matter of bright orange pervades the whole plant in our Wild Balsam-leaves, stem and flower. The Indian women use the juice in dyeing, and also apply it in Erysipelas caused by Poison Ivy and in other diseased states of the skin. Our Balsam loves low wet soil. The low lake shore and forest streams are its favorite haunts, where it attains the height of three and four feet.

There are two species: Impatiens fulva, distinguished by its deeper-colored blossoms, orange, almost scarlet, and its brown spots and darker green leaves; and I. pallida (Nutt.), paler, the markings on the petals slighter, the 


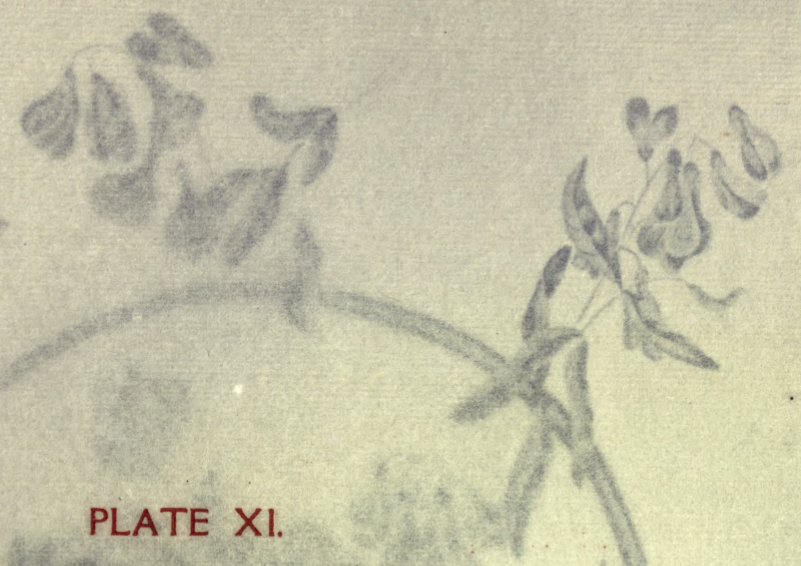

1. Four-leaved Loose-Strife (Lysimachia quadrifolia).

2. Marsh Vetchling (Lathyrus palustris). P. 94.

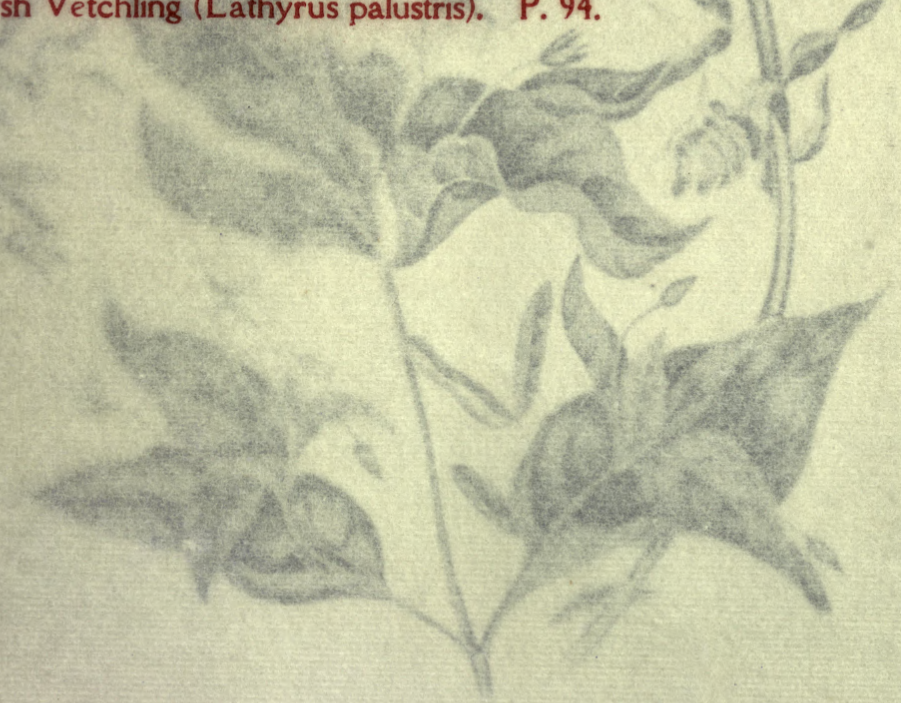




\section{STLDIES OF PLAYR IIth}

Cañaman Batsan-fmpotienes

Dur Wilu Balsan is a singulatly

profusion of orange-colored spotted flos

and semi transparent stems. The butterbin

delight in bovering over the bright blessone

ming-birds may be seen on sunny days with ta

benks and wings winnowing the air as they

tiny bodiss while extracting sweets or inswets

eurimaly-hooded flowers. In the New England

knogm as the Humming-bird Flower, but it hat

pretty descriptive names, Jewel Weed, Spreckled Jewe, anet

Touch-me-not. This last alludes to the sensitive natur al

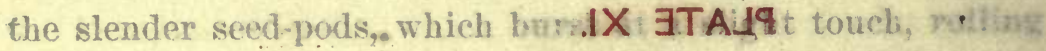

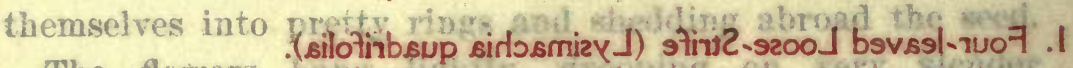

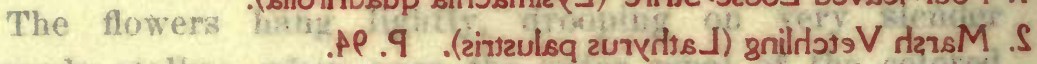
threaly stallos; whitio .

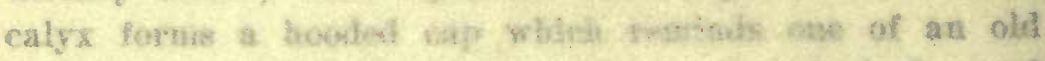

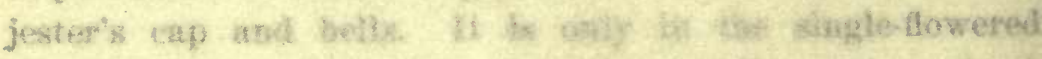

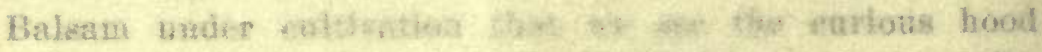

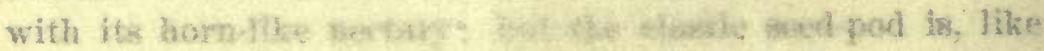

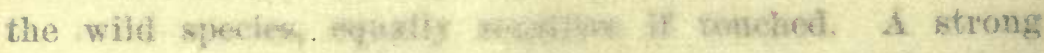

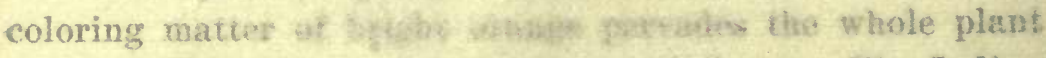

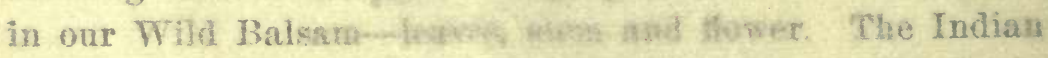
women use the julce fo nfollys, whe shoo apply it in Erysipelas caused by Polscen ing and in other diseased states of the skin. Our Bistigas laves his wet soil. The low lake shore and forest stresmos gax fas favorite haunts, where it attains the height of three and four feet.

There are two species: Inperthos fulpo, distinguished by its deeper-colored blossoms, oralige, abmost searlet, and its brown spots and darker green lectres; and 1 . pallida (Xift.), paler, the markings on the petals slighter, the 
PLATE XI.

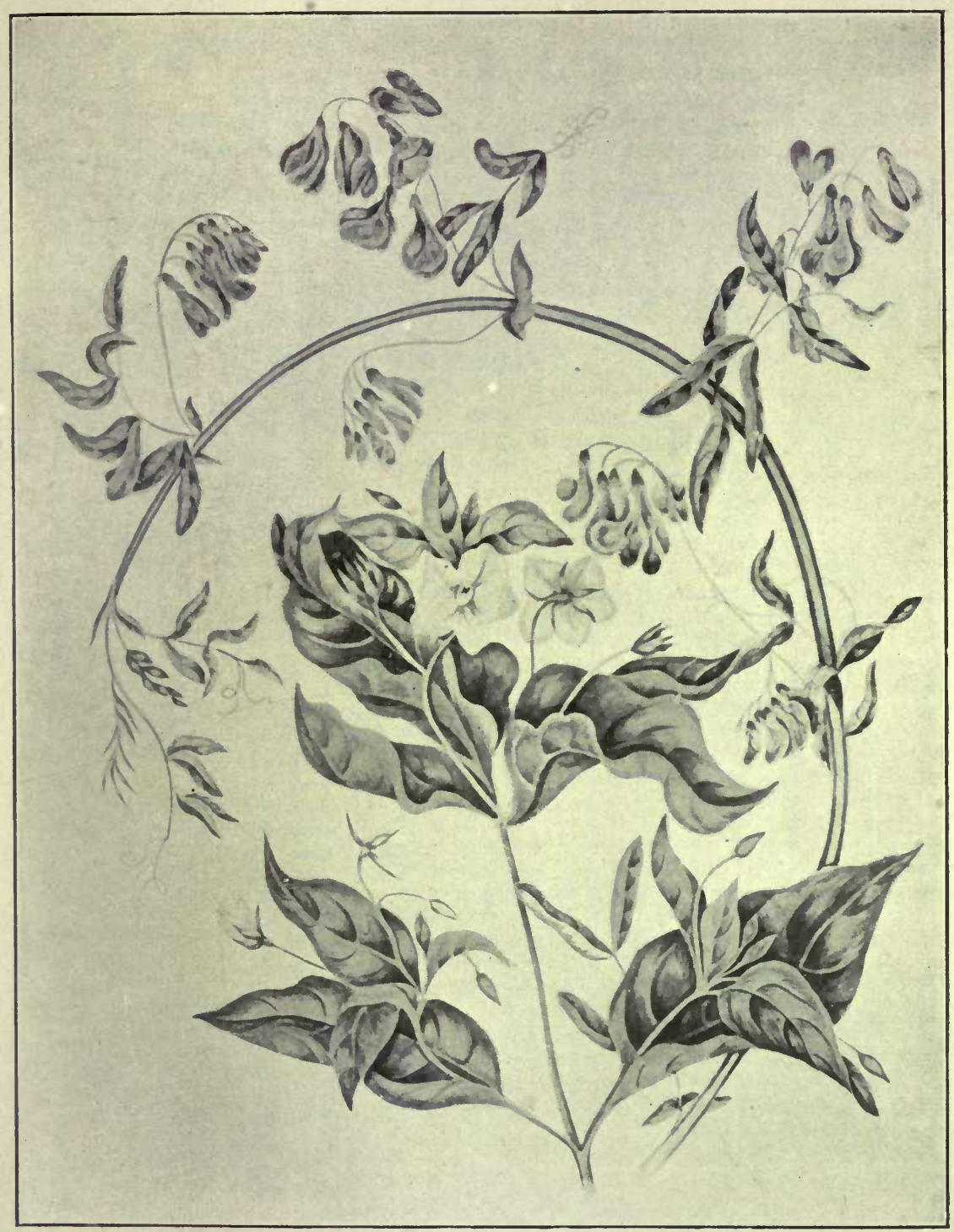





\section{NATIVE WILD FLOWERS}

foliage much lighter, and the juice of the plant more watery.

Professor Lindley has given the Balsam a place among the garden Nasturtiums. A very natural affinity seems to exist between the Nasturtiums and Balsams as respects habits, form and color. Dr. Gray gives the Balsams an order to themselves.

\section{Rattlesnake Plantain-Goodyera pubescens (R. Br.).}

This is a formidable name for a lovely little plant the leaves of which are prettily netted over the dark green surface with milky-white veinings. The ovate pointed leaves are set close to the ground; from the centre of the leaves rises a naked stalk of pearly white flowers in a slender spike; corolla ringent with inflated lip; root-stock somewhat creeping, soft and fibrous; the flowers are slightly fragrant. This pretty little plant is found in the forest, often on decayed fallen trunks of trees or in light flbrous mould. It is very nearly allied to the

\section{SLENDER LADY'S-TRESSES-Spiranthes gracilis (Big.).}

The flower-stem of this singular plant is twisted so that the blossoms are turned to one side, forming a spiral of great beauty. The flowers are smaller but sweeter than those of the Rattlesnake Plantain; greenish-white, lipped and fringed. The two leaves are closely pressed to the ground and are little seen after the plant is in bloom. There are several species of these graceful Orchids.

The spiral arrangement of the flowers probably suggested the ringlets on some fair lady's head. The old florists: and herbalists of former times were more gallant than our modern botanists, for they gave many pretty names to the 
flowers instead of the harsh-sounding, unmeaning ones that we find in our scientific manuals of Botany. So we have among our local and familiar names such prettily sounding ones as "Lady's-tresses," "Sweet Cicely," "Sweet Marjoram," or "Marjory," "Mary-gold," "Lady's-slipper," with a number of others that I could name-besides descriptive names which form a sort of biography of the plant, giving us a correct idea of its characteristics and peculiar uses or habits.

Sweet Scented Water-Lily-Nymphoca odorata (Ait.).

(PLATE XV.)

" Rocked gently there, the beautiful Nymphæa Pillows her bright head."

- Calendar of Flowers.

Water-lily is the popular name by which this beautiful aquatic plant is known, nor can we find it in our hearts to reject the name of Lily for this ornament of our lakes. The White Nymphra might indeed be termed "Queen of the Lakes," for truly she sits in regal pride upon her watery throne, a very queen among flowers. Very lovely are the Water-lilies of England, but their fair sisters of the New World excel them in size and fragrance.

Many of the tribe to which these plants belong are natives of the Torrid Zone, but our White Water-lilies (Nymphoca odorata and tuberosa) and the Yellow Pond-lilies (Nuphar advena, lutea and Kalmiana) only are able to support the cold winters of Canada. The depth of the water in which they grow enables them to withstand the cold, the frost rarely penetrating to their roots, which in the Nymphras are rough and knotted, white and fleshy, and often as thick as a man's wrist. The root-stock is horizontal, sending many fibrous slender rootlets into the soft mud; the stems 


\section{NATIVE WILD FLOWERS}

that support the leaves and blossoms are round, of an olivegreen, containing open pores filled with air, which cause them to be buoyed up in the water. These air-cells may be examined by cutting the stems across, when the beautiful arrangement of the pores can be seen and admired for their use in buoying up the stem and allowing the flower-cup to float upon the surface of the water. These air-cells are arranged with beautiful symmetry, giving strength as well as lightness.

The leaves of the Water-lily are of a full-green color, deeply tinged with red towards the fall of the year, so much so as to give a blood-red tinge to the water; they are of a large size, round kidney-shaped, of leathery texture and highly-polished surface, resisting the action of the water as if coated with oil or varnish. Over these beds of Water-Lilies hundreds of dragon-flies of every color-blue, green, scarlet and bronze-may be seen like living gems flirting their pearly-tinted wings in all the enjoyment of their newly found existence-possibly enjoying the delicious aroma from the odorous lemon-scented flowers over which they sport so gaily.

The flowers of the Water-lily grow singly at the summit of the round smooth fleshy scapes. Who that has ever floated upon one of our calm inland lakes on a warm July or August day but has been tempted, ${ }^{*}$ at the risk of upsetting the frail birch-bark canoe or shallow skiff, to put forth a hand to snatch one of those matchless ivory cups that rest in spotless purity upon the tranquil water, just rising and falling with the movement of the stream; or has gazed with wishful and admiring eyes into the still, clear water at the

* It is decidedly risky, as the stem is not only tough but slippery. After several struggles you may succeed (unless you have a knife to cut the stem) in either breaking off the flower or dragging into the boat several yards of sliny, thick, slippery stems. A. D. C. 


\section{STUDIES OF PLANT LIFE}

exquisite buds and half unfolded blossoms that are springing upwards to the air and sunlight.

The hollow boat-shaped sepals of the calyx are four in number, of a bright olive green, smooth and oily in texture. The flowers do not expand fully until they reach the surface. The petals are numerous, hollow (or concave), blunt, of a pure ivory white, very fragrant, having the rich odor of freshly-cut lemons; they are set round the surface of the ovary in regular rows, one above the other, gradually lessening in size till they change, by imperceptible gradation, into the narrow fleshy petal-like yellow anthers. The pistil is without style, the stigma forming a flat-rayed top to the ovary, as in the Poppy and many other plants.

But if the White Water-lily is beautiful, how much more so is the lovely pink-flowered variety, $N$. odorata, var. rosea, found abundantly in many of the small lakes in the northern counties of Ontario, particularly in the Muskoka district, of such an exquisite shade of color that it could be compared only with the

" Hues of the rich unfolding morn, That ere the glorious sun be born, By some soft touch invisible Around his path are taught to swell." - Keble.

On the approach of night our lovely water-nymph gradually closes her petals and slowly retires to rest in her watery bed, to rise again the following day to court the warmth and light so necessary for the perfection of the embryo seeds; and this continues till the fertilization of the germ has been completed, when the petals shrink and wither and the seed-vessel sinks down to the bottom of the water, where the seeds ripen in its secret chambers. Thus silently and mysteriously does Nature perform her wonder- 


\section{NATIVE WILD FLOWERS}

ful work, "sought out only by those who have pleasure therein."*

The roots of the Water-lily contain a large quantity of fecula (flour), which, after repeated washings, may be used for food; they are also made use of in medicine, being cooling and softening; the fresh leaves are used as good dressings for blisters.

The Lotus of Egypt belongs to this family, and not only furnished magnificent ornaments with which to crown the heads of the gods and kings, but the seeds also served as food to the people in times of scarcity. The Sacred Lotus, or Lily of the Nile (Nymphaa Lotus), found veneration with the ancient Egyptians.

"Lotus-eaters," says Dr. Lee, "not only abound in Egypt, but all over the East." "The large fleshy roots of the Nelumbium luteum, or great Yellow Water-lily, found in our North American lakes, resemble the Sweet Potato (Batatas edulis), and by some of the natives are esteemed equally agreeable and wholesome," observes the same author, "being used as food by the Indians, as are the roots of another species, Nelumbium speciosum, by some of the Tartar tribes."

The people of China, in some parts of that over-populated country, grow Water-lilies upon their lakes for the sake of the nourishment yielded by the roots and seeds.

As yet little value has been attached to our charming White Water-lily, because its uses have been unknown. It

* In that singular plant, the Eel or Tapegrass-Vallisneria spiralis (L)-a plant indigenous to our slow-flowing waters, the elastic stem which bears the pistillate flowers uncoils to reach the surface of the water; about the same time the pollen-bearing flowers, which are produced at the bottom of the water on very short scapes, break away from the confining bonds that hold them, and rise to the surface, where they expand and scatter their fertilizing dust upon the fruit-bearing flowers which float around them; after awhile the stems coil up again and draw the pod-like ovary down to the bottom, there to ripen and perfect the fruit. 
is one of the privileges of the botanist and naturalist to lay open the vegetable treasures that are so lavishly bestowed upon us by the bountiful hand of the great Creator.

Yellow Pond-Lily-Spatter DoCK-Nuphar advena (Ait.).

(PLATE XV.)

"And there the bright Nymphæa loves to lave, And spreads her golden orbs along the dimpling wave."

The Yellow Pond-lily is often found growing in extensive beds, mingled with the White, and though it is less graceful in form, there is yet much to admire in its rich orangecolored flowers, which appear, at a little distance, like balls of gold floating on the still waters. The large hollow petallike sepals that surround the flower are sometimes finely clouded with dark red on the outer side, but of a deep orange yellow within, as also are the strap-like petals and stamens; the stigma, or summit of the pistil, is flat and 12-24 rayed. The leaves are dark-green, scarcely so large as those of the White Water-lily, more elongated, and are borne on long thick fleshy stalks, flattened on the inner side and rounded without. The botanical name Nuphar is derived, says Gray, from the Arabic word neufar, signifying pond-lily.

Nature's arrangements are always graceful and harmonious, and this is illustrated by the grouping of these beautiful water-plants together, the ivory white of the large Lily mingling with the brighter, more gorgeous color of the yellow; and the deeper green of the broad shield-like leaf contrasting with the bright verdure of that of the Arrowhead and the bright rosy tufts of the red Water Persicariathe leaves, veinings and stems giving warm tints of color to the water as they rise and sink with the passing breeze. 


\section{NATIVE WILD FLOWERS}

Where there is a deep deposit of mud in the shallows of still waters we frequently find many different species of aquatics growing promiscuously, the tall lance-like leaf and blue, spiked heads of the stately Pontederia cordata keeping guard, as it were, over the graceful Nymphæa, like a gallant knight with lance in rest ready to defend his queen; and around these the fair and delicate white flowers of the small Arrow-head* resting their frail petals upon the water, looking as if the slightest breeze that ruffled its surface would send them from their watery pillow.

Beyond this aquatic garden lie beds of Wild Rice ( $Z$ izania aquatica), with floating leaves of emerald green and waving grassy flowers of straw-color and purple; while nearer to the shore the bright rosy tufts of the Water Persicaria (Polygonum amphibium), with dark-green leaves and crimson stalks, delight the eyes of the passer-by.

\section{SPIKENARD-Aralia racemosa (L.).}

This valuable plant is distinguished by its heart-shaped five-foliate pointed and serrated leaves, wide-branching herbaceous stem, long white aromatic astringent root, greenish-white flowers and racemose branching umbels of small round purple berries, about the size and color of the purple-berried elder. It affects a rich deep soil, the long tough roots sometimes extending to a yard or more in length, forking and branching repeatedly. The plants are often seen growing on large boulders where there is a sufficiency of soil, the roots penetrating into the crevices or extending horizontally over the surface. Another favorite place for this plant is in the earth adhering to large upturned roots, the seed having been left by the birds. The root has an aromatic taste and smells like aniseed or See Plate X. 


\section{STUDIES OF PLANT LIFE}

caraway. It is a most valuable domestic medicine, safe and simple; its curative properties in cases of obstinate dysenterical disorders deserve to be widely known.

It was from an old Canadian settler that I learned the virtue of the Spignet-root, for it is by that name it is known in country places. I have tested its efficacy in many cases of that common and often fatal disorder to which young children are subject during the hot summer months in Canada. For the benefit of anxious mothers I give the following preparation from this valuable root:

Recipe.-Take the long roots, which are covered with a wrinkled brown skin, wash them well and remove the outer bark; then scrape down the white fibrous part, which is the portion of the root that is to be made use of, throwing aside the inner hard central heart, which is not so good.

A large tablespoonful of the scraped root may be boiled in a pint of good milk till the quantity is reduced to onehalf; a small stick of cinnamon and a lump of white sugar boiled down with the milk improve the flavor, add to its astringent virtue, and make the medicine quite palatable. The dose for an infant is a teaspoonful, twice a day; for an adult, a dessert-spoonful twice or thrice a day, till the disorder is checked.

The months of August and September are the best time to obtain the roots, which have then come to perfection.

The strengthening and purifying nature of this plant makes it quite safe as a medicine even for a young infant. The preparation is by no means unpalatable; it is sweet and slightly bitter, aromatic and astringent. I have seen children that had been reduced to the last stage of debility restored, after taking three or four doses, to a healthy state of body; it purifies the blood and strengthens the system. 


\section{NATIVE WILD FLOWERS}

This plant, and Aralia nudicaulis (L.), or Wild Sarsaparilla, are held in great repute as wholesome tonics by the old settlers.

The Ginseng (A. quinquefolia-Gray), or Five-leaved Sarsaparilla, is known by its scarlet berries.

\section{DWARF Ginseng-Aralia trifolia (Gray).}

This is a pretty, delicate little plant with three palmately three to five-foliate light-green leaves, which form a leafy involucre to the small delicate umbel of whitish-green flowers which surmounts them. The root is a round tuber, deep below the soil; it is pungent to the taste.

\section{MONKEy Flower-Mimulus ringens (L.).}

Our Mimulus is a sober-suited nun, not gorgeously arrayed in crimson and golden sheen, scarlet or orange, but in a modest, unobtrusive dark violet color, that she may not prove too conspicuous among the herbage and grasses. Her favorite haunt is in damp soil by low-lying streams and open swampy meadows, among moisture-loving herbs, coarse grasses and sedges, and dwarf sheltering bushes. Yet our Mimulus is by no means devoid of beauty, the dark violet-purple of the corollas being unusual among wildflowers. The blossoms grow from between the axils of the leaves, singly, on rather long footstalks; the upper lip of the tubular corolla is arched, the lower spreading and thrice lobed; the leaves are long, of a dullish green, often, with the angled upright scape, taking a bronzed purple tint.

\section{MAD-DOG SKullCaP-Scutellaria lateriflora (L.).}

This pretty light-blue flower grows on the low-lying shores of the Katchewanook Lake and other localities on the banks of the Otonabee and its tributaries. The stem is 


\section{STUDIES OF PLANT LIFE}

slender, branching, the leaves rather coarse; color of the blossoms azure blue, with the small upper lip somewhat curved.

The old settlers imputed great virtues to this very humble herb, which it is more than doubtful if it possesses. Good faith, however, will often work marvellous cures. The idea was that the plant would avert the terrible effects of the bite of a mad dog.

There is also a much handsomer species with larger flowers and simpler stem-the Common Skull-cap (S. yalericulata).

Marsh Vetchling-Marsh $\cdot$ Pea-Lathyrus palustris (L.). (PLATE XI.)

The Marsh Vetchling or Marsh Pea is a graceful climbing plant with purple flowers and long slender leaflets, arranged in pairs from two to four or six along the leafstalk, which terminates in a cluster of clasping thread-like tendrils. The flowers are placed on long slender arching peduncles springing from the base of the leafstalk, which is furnished at the joint with a pair of sharply-pointed stipules.

The Marsh Pea is found chiefly in damp ground, among herbs and dwarf bushes, along the margins of low-lying lakes and creeks and sandy grassy flats. Its pretty purple pea-shaped blossoms and pale-green leaves attract the eye as it twines among the herbage and forms graceful garlands amidst the ranker and coarser plants to which it clings. A taller species with slender stalks two to four feet high, with ovate-elliptical leaves, much larger stipules, and an abundance of small pale blue-purple flowers, is also found on marshy shores. This is the variety myrtifolius of Gray.

There are many other graceful twining plants of this order. The most remarkable of these is the 
Ground NUt-Wild BeaN-Apios tuberosa (Mœnch.),

known also as Indian Potato and Sweet Bean, a tall climber, with compound leaves of five to seven ovate leaflets and sweet-scented clustered flowers of a brownish-purple color; the pear-shaped tubers, of the size of a hen's egg, are used as an article of food by the Indians, who roast them in the embers and eat them as we do baked potatoes. A fine white starchy substance, tasteless and not unwholesome, can be obtained by grating the tubers.

\section{BUTTERfLY WeED-Asclepias tuberosa (L.).}

Of this remarkable family Canada possesses many handsome species. The most showy is a large bushy plant with gorgeous orange, almost scarlet, flowers. Every branch is terminated by a wide-spreading head composed of small umbels of brilliant flowers. This plant is known by the name of Butterfly Flower from its singularly gay appearance, which is very attractive when seen on dry hills on sunny days. The root is used in medicine as a powerful vermifuge by the old settlers, who say they learned its medicinal virtues from the Indian herb doctors.

The floral construction of the flowers of all this family is peculiar. The petals are somewhat pointed, five in number; divisions of the calyx also five; the petals are reflexed, showing a central crown, which is composed of five hooded nectaries, each of which encloses a curved horn-like appendage. The crown is often of a different shade of color from the petals, and from its peculiar form the flower has the appearance of being. double. The leaves of the Butterfly Flower are rough on the surface and hoary; the seed-pods are also hoary. It is a striking and showy flower, deficient in the viscid milky juice that is so abundant in others of the genus. 


\section{STUDIES OF PLANT LIFE}

The Pink-flowered Milkweed (A. Cornuti) is fragrant and also handsome; it is a tall showy plant, abounding in milky juice; the leaves are large, soft, and velvety; the flowers are of pale pink, falling in graceful tassels from between the leaves; the form of the flowers is the same as in the above; the seed-pods are large and the seeds flat, lying one over the other, closely pressed, in beautiful succession, like the shining silvery scales of a fish; each seed is furnished with a tuft of silken hair.*

The pod opens by a long slit, and it is wonderful to see the beautiful winged seeds, the instant the prison door is opened, rise as if moved by some sudden impulse, spreading their shining silken wings and taking flight, wafted away by the slightest breeze to parts unknown. One marvels how this winged multitude ever found space to lie within the narrow case from which they escaped; it reminds one of that wonderful genius of the old Arabian tale that the poor scared fisherman induced to re-enter the metal pot. Methinks it would be even harder to gather together our fugitive silky seeds than to coax a refractory genius into a quart pot again!

The whole of the Asclepias family are remarkable for the strong tough silken fibre that lines the bark of the stout stem. This in the common Silk-weed ( $A$. Cornuti) has attracted much attention, but has not as yet been utilized for textile fabrics. The fibre is strong and can be divided into the finest threads of silken softness and of good length, as the plant reaches from two to three feet or more in height and grows so freely that I have seen extensive plantations of it on wild spots, where it has been self-sown and where few other plants would grow.

* The farmers' wives make pretty cushions of this white flax-like silk, by filling bags of tulle or net with them, the shining silk showing through any transparent fabric. 


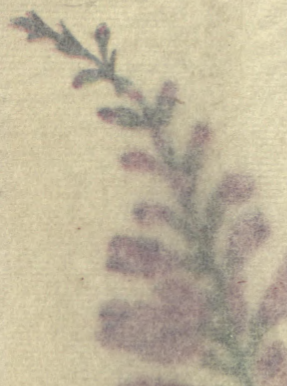

\section{PLATE XII.}

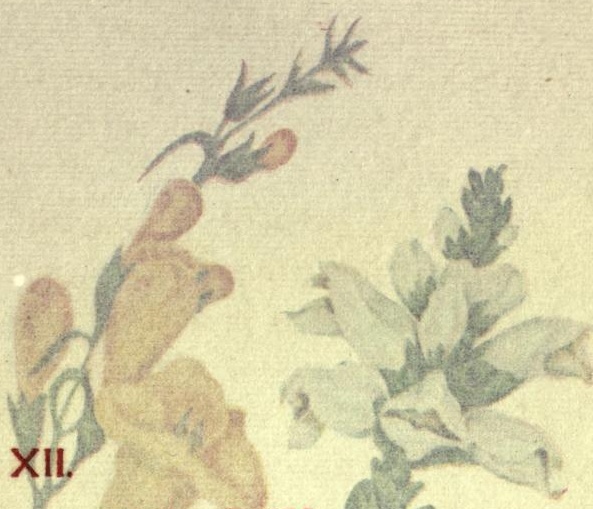

1. False Foxglove (Gerardia quercifolia). P. 132.

2. Turtlehead (Chelone glabra.), P. 138.

3. Dragonhead (Physostigia Virginiana).

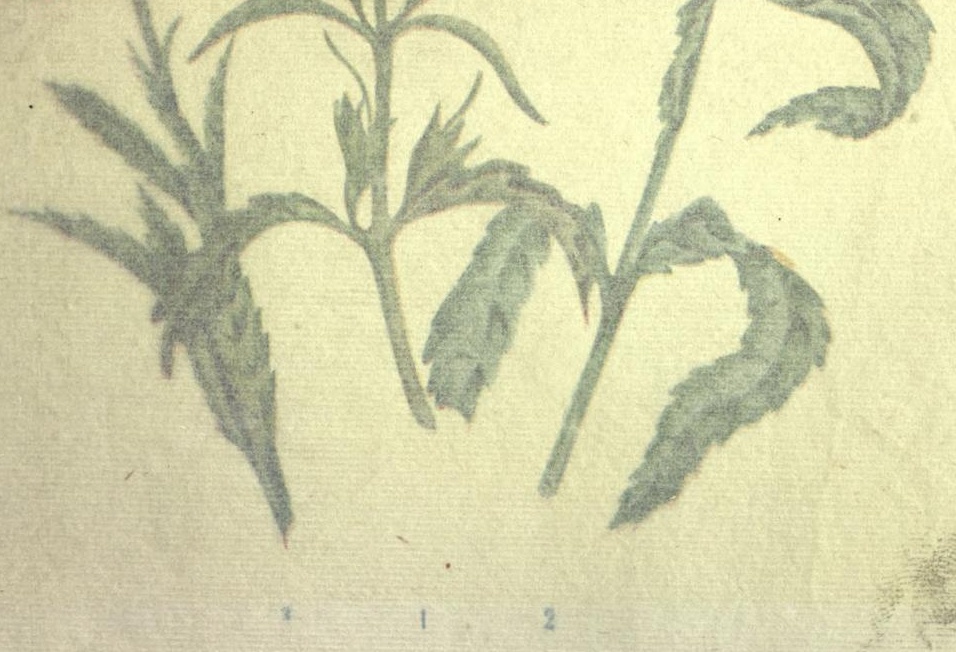




\section{The Pink-flowered Milkweed}

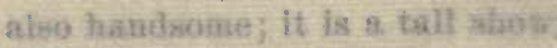

juice; the leavere are lange, solf, and vit

of pale pitric falitigg in graceful tasotels

leares: the thatis of the flowers is the bam.

the sowelpats are large and the seeds flat,

ofhen, ensely pressed, in beautiful succession,

whilwery scales of a fish; each seed is furnished with is sitken hair."

The por opens by a long slit, and it is wonderful to fic the beautiful winged seeds, the instant the prison door is opened, rise as if moved by some sudden impulse, spreadiug their shining silken wings and taking flight, wafted away by the slightest breeze to parts unknown. One marvels how this winged multitude ever found spaIIX ITAJ9ithin the narrow case from which the eseaver: in reands one of that

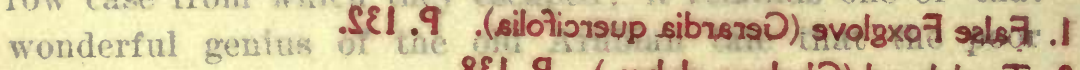

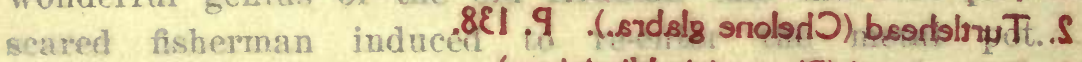
Methinhs it wonld be even (onsinigriV sigirozyd 9) bsadnagandr. $\mathcal{E}$

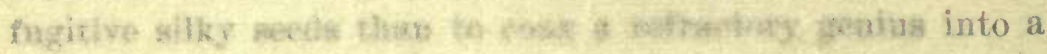
ginart pot agalo:

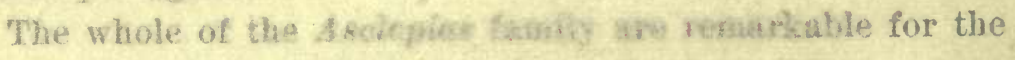
strong tough silkeu fibre that lines the bark of the stout stem. This in the rommon sits weel (it. Cormeti) has attracted much attention, but has not as jet been utilized for textile fabrics. The fibre is stroug and can be divided into the finest threads of silken solmess and of good length, as the plant reaches from two to three feet or more in height and grows so freely that 1 have seen extensike plantations of it on wild spots, where it, has been self-sown and where fow other plants woth giow.

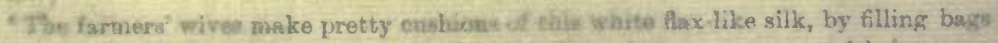

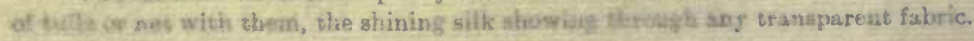




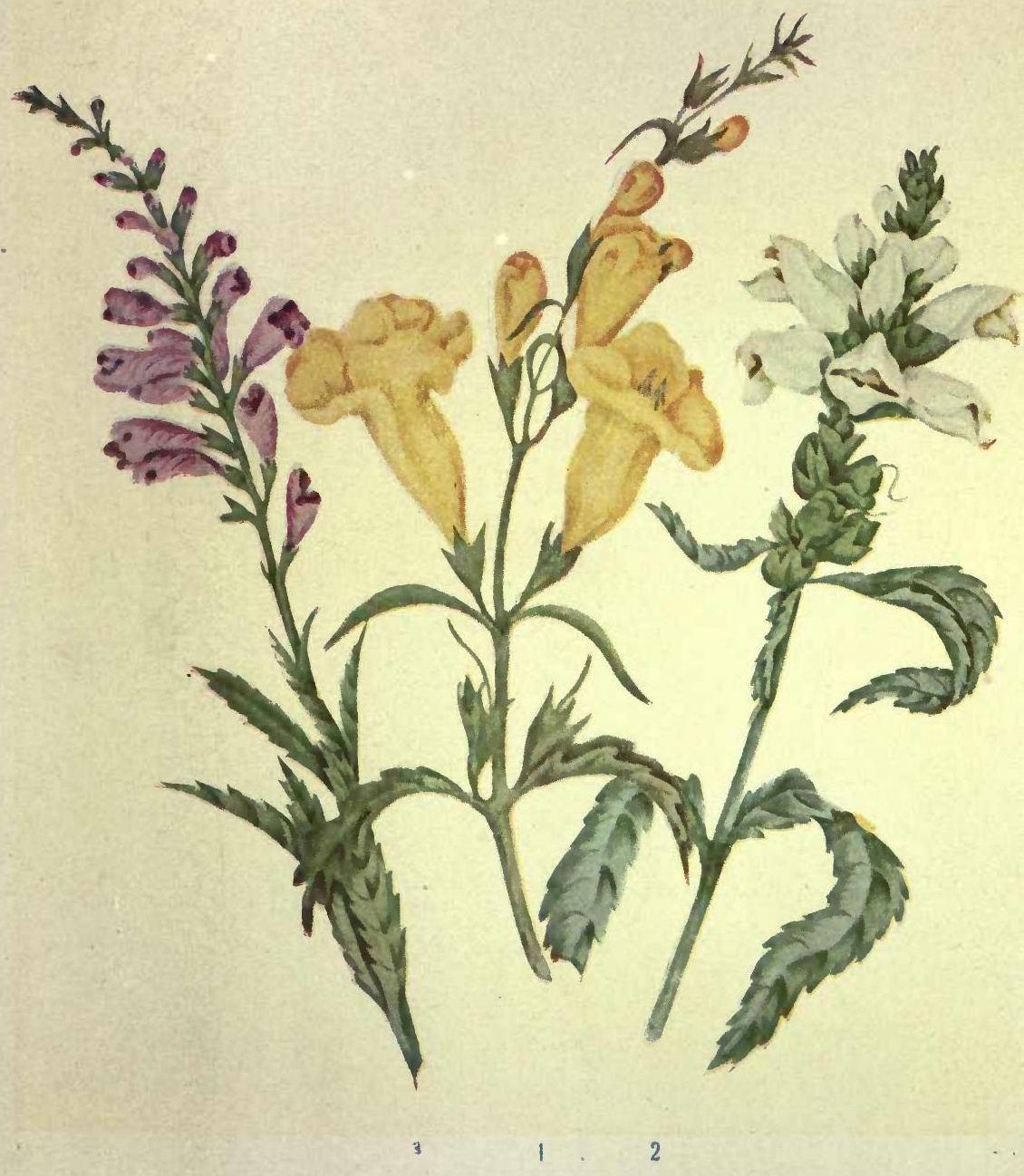





\section{NATIVE WILD FLOWERS}

The silken beard of the seed, though so bright and beautiful, is too short and brittle for spinning; still, as a felting material, or for paper manufacture, it might prove of value, for even the pod might be employed. A good fibre is found in all the tall Milkweeds, and also in the Apocynums or Dogbanes, where the thread is still finer. All these plants are remarkable for the bitter viscid milky juices with which they abound.

We know nothing in medicine experimentally of this tribe of native plants, but I believe they are supposed to contain poisonous properties of a narcotic nature, as is the case with most regetables containing acrid milky juices.*

It would add greatly to the value of botanical books if a few words as to the poisonous character of native plants were inserted.

\section{WILLOW-HERB-Epilobium angustifolium (L.).}

This handsome, showy plant, with its tall wand-like stem and abundant blossoms of reddish lilac, adorns old neglected fallow-lands that have been run over by bush fires, and open swampy spots, where it covers the unsightly ground with its bright colors and drooping stems, which are often borne down by the weight of their blossoms and fair buds. It often shares these waste places with the White Everlasting (Antennaria margaritacea), Wild Red Raspberry, Blackberry, and the Fireweed, with a variety of smaller plants that take possession of the virgin soil, there to perfect their flowers and fruit, while at the same time their abundant foliage serves to cover the confusion caused by charred and blackened trunks and branches of prostrate

* It is supposed to cure the bite of a rattlesnake, and it is strange that it always grows in abundance where there are rattlesnakes. An old saying that an antidote is always near a poison may be true. The milk is also a cure for warts.-A.D.C. 


\section{STUDIES OF PLANT LIFE}

trees. Over all these the graceful Willow-herb waves its flowery spikes and long willowy leaves. All through the months of July, August and September it blooms on, while later in the season its silky-plumed seeds fill the air as they wing their way to other wild spots equally favorable for their growth and development.

The midribs of the leaves are white or rosy red, as also are the wand-like stems and branches. The terminal naked buds are of a deep crimson; the seed-pod is long and opens lengthwise to allow the seeds to float off on the breeze by means of their silky sails.

The Willow-herb is cultivated in gardens in England, where it is known by the name of French Willow. I remember seeing it in almost a wild state in a picturesque old garden in Suffolk, where it grew to the height of seven or eight feet, the long flowery wand-like stems drooping over the margin of a fish-pond, where, beneath the shadow of a big old willow, I used to sit and feed the silver-scaled carp, which were so fearless that they came and fed upon the crumbs that I threw into the water.

Evening Primrose-OEnothera biennis (L.), var. grandiflora (Lindl.).

" A tuft of Evening Primroses

O'er which the mind might hover till it dozes,

But that it's ever startled by the leap

Of buds into ripe flowers."

- Keats.

In common with the Northern and Eastern States, Canada owns many native flowers of this fine family. Our largest variety of $C E$. biennis is deliciously fragrant, with large showy flowers of a deep sulphur color-of all the shades of yellow the most beautiful and satisfying to the 


\section{NATIVE WILD FLOWERS}

eye, so full, so soft and delicate is the hue. Some species of the Evening Primrose, true to their descriptive name, open their blossoms only at sunset; others bloom during the daytime and endure the light and heat of a July or August sun. One form of the grandiflora is from three to four feet high, with stout branching stems and many-flowered spikes; others are low in stature, with rough hoary leaves and smaller flowers. $E$. pumila, a dwarf species, about six inches in height, has small flowers of pale color and of little floral beauty. $Q$ E. biennis (L.), var. muricata (Gray), which is common in open fields and plains, is a large branching species with smooth, redveined leaves, a red bristly stem, and smaller flowers than grandiflora. It is less fragrant but is a handsome species and continues flowering all through the summer till cut off by early frosts. But by far the finest and most interesting of our Evening Primroses is the large-flowered fragrant grandiflora under consideration. No sooner has the sun set than one after another may be seen, in quick succession, the bursting of the closely-shut sepals of the calyx. One by one the petals begin to unfold-slowly, slowly. You notice a slight movement in the corolla; first one petal is loosened from its plaited folds, then another, till in a few seconds the whole flower expands and opens its beautiful deep sulphur-colored cup with its eight stamens and yellow anthers, giving out a delightful scent upon the dewy air. What an object of interest is this flower to children as they gaze with watching, wondering eyes upon its fair unfolding blossoms. One little fellow, almost a baby, cried out, " $\mathrm{Oh}$, look! it's waking now!" when he saw the first pure petal softly rolled back as the blossom commenced opening. The diagonal lines which cross the surface of the flower are caused by its twisted astivation, or folding in the bud, and 


\section{STUDIES OF PLANT LIFE}

this gives it a crimped appearance which is singularly pretty as well as curious. It has been stated that a flash of phosphorescent light has been noticed at the instant the flower opens, but I think a tiny flash of such pale light would hardly be perceptible during the daylight; besides, the petals unclose gradually - the only sudden motion is the unclasping of the enfolding calyx leaves which emprison the corolla. Nevertheless it is a pretty idea, and it may be a fact, though not as yet a fully established one. I think it is Professor Lindley who has recorded the circumstance in his "Natural System of Botany," from the observation of some French naturalist.

EnChanter's Nightshade-Circáa alpina (L.).

With so ominous a name we might naturally expect to find some sad lurid-looking poisonous weed or sombreleaved climber, instead of a very delicate, innocent-looking leafy plant, with thin light-green foliage and tiny white or pale pink blossoms dotted with minute spots of pale yellow, something like the old garden plant London Pride. One can hardly imagine so inoffensive a little flower being introduced by the ancient sibyls into connection with their unholy rites, nor understand why its classical name, Circoea, after a horrible old enchantress, should have been retained by our modern botanists.

We often wonder at the Greek names given to plants which are indigenous to other climes than Greece, and retained even where the significance is so obscure as to be questioned by our botanical writers. It is these hard classical names that frighten youthful students, especially young ladies, who are only too glad when they can meet with names of flowers that give them an insight into the 


\section{NATIVE WILD FLOWERS}

appearance and qualities of the plants by which they can be easily recognized.

Imagination loves to get a glimpse at the poetical in the names of flowers, giving a charm to what is dry and uninteresting in our botanical books; something that gives us an insight into the history of the flower we study beyond the mere structure and definition of its parts. I remember an old gardener (he was by no means an ignorant man) once said, "Oh! madam, in these days they turn poor Poetry out of doors, but in the olden time it was not so, for it was the language in which God spake to man through the tongues of angels and prophets. Ay, and it was the language in which even sinful man spake in prayer to his Maker; but now they only use hard words for simple things, such as the flowers of the field and the garden; or the talk is about gold and the things that gold purchases!"

\section{Spreading Dogbane-Indian Hemp-Apocynum andro- sœmifolium (L.).}

This pretty pink-flowered plant is also known by the name of Shrubby Milkweed, from the abundance of acrid milky juice that pervades the stem, branches and leaves.

The flowers of this plant are very unlike those of the Asclepiadacea; but it belongs to a closely allied order, and possesses some of the characteristics of that remarkable order of plants in which the deadly Strychnia is included, with others of evil reputation. There are many virtues as well as vices in our Milkweeds. The Apocynums have some worthy members in the family-sweets as well as bitters.

In the "Hya-hya" of Demerara we find the luscious Milktree, which, with the Cream-fruit of Sierra Leone and some others, redeems the character of this remarkable tribe 


\section{STUDIES OF PLANT LIFE}

of vegetables. Our own native Shrubby Milkweed has some marked peculiarities which deserve notice: in common with all the Milkweeds it has a strong fine silky fibre in the bark, which can be drawn to a great degree of fineness and in one of the species, Apocynum cannabinum (Indian Hemp), is exceedingly tough and strong; it is said to have been used by the natives in lieu of thread. No doubt it can be put to such purpose. While many writers have dwelt upon the silk contained in the pods of the Milkweeds, suggesting the possible uses to which it might be applied, the more valuable strong flaxen fibre, which is superior in quality. to hemp, seems in a large measure to have escaped public attention. The free growth of the common whiteflowered Milkweed, "which could be easily cultivated, growing readily and attaining the height of three or four feet, would give a long thread easily divided into the finest strands, and might form, as I have already remarked, a valuable addition in the manufacture of native Canadian fabrics.

The ancient name, Apocynum, is derived from two Greek words signifying "from a dog"; this shrub was supposed to be injurious or baneful to dogs, whence its common name, Dogbane. Whether the plant deserves this reproach as regards dogs I cannot say; but truth obliges me to confess that in its pretty treacherous bells many a poor incautious fly meets with a certain, though possibly lingering, death. Lured by the fragrance of its blossoms, which it gives out at dew-fall, hundreds of small black flies seek rest and shelter in the flowers, and are seized instantly by the irritable stamens and held in durance by their legs; and as there is no philanthropist to take his nightly rounds and release them, they perish in their flowery prison. 


\section{NATIVE WILD FLOWERS}

Though the Dogbane is perennial, the stems die down annually and are renewed again each spring. The bark is of a deep red; the foliage, on distinct footstalks, ovate and pointed. The flowers appear in loose spreading cymes; the pale rose, somewhat striped corolla open bell-shaped, with recurved lobes. The flowers are followed by long slender red pods, meeting in pairs at the points in twos and fours, the pods converging together; these pods open longitudinally and let out the small winged seeds, each of which is furnished with a tuft of delicate silk. The whole plant is milky, more so than the next less showy-flowered species,-

\section{INDIAN HEMP-Apocynum cannabinum (L.).}

The flowers of this species are white, small, and in terminal cymes; the leaves are narrow, of a dark green, smooth; the fibre in the bark of this plant is very strong as well as fine. The Indians use this thread in the manufacture of fishing nets and lines, and probably in sewing. The banks of streams and lakes seem to be the habitat of the Indian Hemp. I am not aware that it has any scent. The scent of the pink Dogbane is only given out after sunset.

\section{White DWarf Convolvulus-DaY-Flower-Convolvulus} spithamous (Pursh).

Although so delicate and fragile in texture, there is no flower that loves the sunlight in its noontide power more than this lovely wild Convolvulus. In this it differs from the splendid Morning Glory, which opens early, in the freshness and coolness of the morning but fades before the noonday heat and light; only on cool cloudy days will it display its glorious tints of royal purple, rose, crimson, and exquisite shades of pink, pearly-blue, and white. But our modest white flower may be seen blooming in open fallows 


\section{STUDIES OF PLANT LIFE}

and wild grassy plain-lands, where it has little shade unless from the surrounding herbage. The plant is seldom more than twelve or eighteen inches in height, tapering from a broad base to a slender leafy point. The foliage is whitish or hoary gray, from a minute downy covering. These gray leaves are hastate, not arrow-shaped, pointed and lobed at the base; the lower leaves are on long footstalks, the upper ones diminished to mere bracts. The flowers are large pure white open bells, on long stalks-only two opening each day. The stem of the plant is somewhat woody, slightly branching or simple, and forming a pyramid of slender apex, twining slightly and clasping the stalks of grasses and neighboring herbs.

On the flowery Rice Lake plains I have seen this lovely flower mingling its hoary foliage and white fragile bells with the gay bracts of the Scarlet Cup and azure-blue spikes of the Wild Lupine, the Sweet Pyrola and Wild Rose,-and surely no garden ever shewed more glorious colors or more harmonious contrasts than this wilderness displayed.

This pretty wild Convolvulus might be introduced into garden culture, where the soil is light, without any fear of its becoming a troublesome weed like the common Bindweed, or the double-blossomed variety, which should only be kept as plants for a trellis or as bower-climbers.

\section{Grass-Pinik Calopogon-Calopogon pulchellus (R. Br.).}

Our open springy poplar flats, partially shaded by aspen shrubs and wild grasses, afford shelter to many a rare Orchid. The warm rays of the sun, acting on the moist boggy soil, quicken into life and loveliness one of the most ornamental of our orchidaceous plants. In the month of July we find that very beautiful flower, the Grass-pink, or Calopogon. Its flowers are little known, and may indeed truly be said to waste their sweetness on the desert air. 


\section{NATIVE WILD FLOWERS}

From a round solid corm, about a quarter of an inch in diameter, rises a bright green sword-shaped leaf, which clasps at its base a tall scape bearing a loose four to eightflowered raceme of elegant rose or lilac-colored flowers. The lower blossoms open first. The form of the flower is peculiar: the concave upper petal or lip is bearded with yellow and purple hairs arching over the column, which is winged and free; the bright reddish-purple sepals and petals are pointed and fragrant; the scape rises to the height of from eighteen inches to two feet. A bed of these elegant flowers when in bloom is a charming sight.

Another of our Orchids is the lovely and rare Arethusa bulbosa (L.), the flower of which is no less remarkable for the beauty of its form and rich coloring than the Calopogon. The color of the ringent corolla is of a deep rich rose-purple, and it is very sweetly scented; the scape has occasionally one grassy leaf. Not less singular is the charming Calypso borealis (Salisb.), or Bird's-foot Orchis, with its graceful, deliciously-scented pendulous flowers and crested lip, bearded with yellow and pink, and its.narrow, twisted and waved pale pink sepals and petals; the scape is garnished with one oval shield-shaped shining leaf of dark glossy green. It flowers in the month of May.

Another elegant bog-plant is the

\section{SMall Round-LEaved ORCHIS-Platanthera rotundifolia}

(Rich.).

" Your voiceless lips, O flowers, are living preachers ;

Each cup a pulpit, and each leaf a book.

" Floral apostles that in dewy splendor

Weep without woe and blush without a crime."

-Horace Smith.

This is one of the lovely native plants of the Orchis family, of which we boast many remarkable for beauty as 


\section{STUDIES OF PLANT LIFE}

well as for the eccentric forms which arise from the peculiar arrangement of their floral organs.

The one above named is worthy of attention. Our quaint old herbalists would have called it the Holy Dove, or some such name, from the curious resemblance that the petals and sepals take to the body and extended white wings of a hovering dove, the lower lobed petal taking the semblance of the tail and wings, the upper ones meeting over the anther-cells, which might be likened to the two eyes of the bird, and the arched hooded appendage above to the head.

The scape of this pretty Orchis is furnished with one handsome round or shield-shaped leaf, of shining bright green, and a bracted spike of white flowers, spotted with delicate pink, as also is the throat of the arched petal that partly covers the anthers and stigmatic disc.

Our beautiful Orchids, with many other rare bog plants, repay the difficulties of obtaining them in their native haunts, such as cedar swamps, cranberry marshes, poplar swales, and peat bogs, where, however zealous, our lady botanists may not venture without risk.

These rare plants, growing in lonely isolated places, are little known and but seldom met with, unless, as I have said, by the enthusiastic botanist who is not afraid to seek for such floral treasures, however difficult they may be to obtain. A curious and handsome species is the Striped Orchis or Coral-root (Corallorhiza striata, Lindl.). This plant is leafless, silvery-sheathing scales taking the place of leaves; the roots are branched and knobby, like some kinds of coral; the scapes, many flowered, grow up in clusters from twelve to eighteen inches high; the flowers are pale fawn, striped and dotted with crimson or purple-such was a plant that I found at the root of a big hemlock tree near the forest road where I often walked many years ago. 


\section{NATIVE WILD FLOWERS}

There are several different species of this curious order, varying in size and the color of their blossoms. Of fringed and tufted, fragrant kinds, we have the Pearly White and the Fringed Pink Orchids. These are very pretty and not uncommon flowers. I first saw them on my voyage up the St. Lawrence, when the ship was anchored off Bic Island and the Captain brought me a noble posy of sweet flowers, the first Canadian flowers I ever saw. Among Wild Roses and elegant Blue Lungwort (Mertensia maritima), which I had also seen and gathered near Kirkwall, in Orkney, there were yellow Loosestrife, Harebells, and the sweet-scented White-fringed Orchis, the Pink-fringed Orchis and some elegant cream-colored Vetches, with several other flowers then unknown to me.

There are many other plants of the Orchis family scattered through our woods and swamps and on the rocky or low islands of our northern lakes. Among those not already mentioned, the Larger Fringed Orchis (Habenaria fimbriata) may be named. This is a tall handsome bogplant, flowering in the beginning of July, with large rosepurple deeply-cut petals. Another less conspicuous species, found in dry woods, is the Northern Green-man Orchis, Habenaria viridis (L.), var. bracteata (Reich). The scape of this species is furnished with long narrow sharply-pointed bracts and greenish flowers.

In some of our orchidaceous plants when examined there will be seen at the base of the fleshy scape two roundish bulbs or tubers, farinaceous masses, whence the bundle of white fibres, the roots and rootlets proper, proceed, and which contain the prepared food to support the growth of the year.

From one of these tubers the scape, bearing the scaly or leafy bracts, root-leaves and flowers, springs, and at the flowering season is much larger than the other. 


\section{STUDIES OF PLANT LIFE}

The flower-bearing bulb deceases from exhaustion of its substance, shrivels, turns brown, and begins to decay, while the other continues slowly but steadily to go on increasing, bearing in its bosom the embryo flower-stem and foliage which are to appear the following year. Another tiny bulb is also preparing in like manner, attached by a slender fleshy cord to its companion. Thus from year to year the process goes on, each one taking the place of its predecessor after its office has been fulfilled.

This singular mode of reproduction seems to supersede the necessity for the development of seed as in other flowering plants; nor is it so common to find seedlings of the Orchids springing up round the parent plant, as in the case of other flowers.

The reason why so few amateur florists succed in transplanting the native Orchids into their gardens lies in the want of due care in taking them up. The life of the plant for the following season being contained in the new forming tuber, if this be in the least injured the chance of another flower in the future is at an end. The succulent tender roots are easily broken or wounded, and these strike rather deep down in the soil and must be taken up uninjured, with a good portion of the mould, or there is small chance of life for the plant. Nor will the Orchis thrive in common earth; it requires fibrous peaty soil, moisture, and some shade, with the warmth that arises from the moist soil and shelter of the surrounding herbage. They all thrive best in the conservatory or greenhouse.

\section{GoLden DodDER-Cuscuta Gronovii (Willd.).}

This singular parasitical plant occurs on the rocky shores of our inland lakes. There seem to be two species: one 
with bright orange-colored coils and greenish white flowers; the other with green rusty wiry stems and smaller blossoms. This last occurs on the rocky shores of Stoney Lake, where in the month of August it may be found twining around the slender stems of the Lesser Goldenrod, a small narrowleaved Solidago.

In no instance did I find this curious parasite associated with any other plant; as if by some mysterious instinct the Goldenrod seemed to be selected for its support. Nor conld the union with the flower be discovered by the most carefil examination. The Dodder seems to be leafless and rootless. The Goldenrod to which it had attached itself did not appear to have suffered from the clinging embrace of its singular companion, though its coils were so tightly wound around it that it was not an easy matter to separate them from the supporting stem. The Dodder could not even be said to have the claims of a poor relation to excuse its unwelcome intrusion. The white blossoms of this parasite were closely clustered at intervals on the wiry stem.

The golden-stemmed species, with somewhat larger yreenish-tinged white flowers, I found in the same locality attached to the culms of stout wild grasses, which chiefly it seemed to have selected for its support. The bright orange coils and clusters of flowers formed a pretty contrast with the dark foliage of the climbing Indian Bean (Apios tuberosa), many young plants of which handsome fragrant climber grew there in profusion, covering the low bushes.

In the States it is known as Goldthread, from the bright orange thready twining stems which it throws like a golden net over the neighboring herbage. It seems, indeed, more ornamental than useful; but as it does not intrude itself into our gardens we will not quarrel with it. There is 
room and space in this wide world for it and others to find some little spot in which to grow. Each has its own particular and ordained use.

" Nothing lives, or grows, or moves in vain;

Thy praise is heard amid her pathless ways, And e'en her senseless things in Thee rejoice."

-J. Roscoe.

\section{Everlasting Flowers.}

"Bring flowers for the brow of the early dead."

It is on the open prairie-like tracts of rolling land known in Ontario by the names of oak-openings and plains, where the soil is sandy or light loam, that flowers of the Composite Order abound. All through the hot months of July and August, and late into September, the starry-rayed blossoms of the sun-loving Sunflowers, Rudbeckias, Asters and Goldenrods enliven the open wastes and grassy thickets with their gay colors-the more welcome because that the more delicate of the early spring and summer flowers have long since faded and gone, and we know that we shall see them no more.

Our floral calendar might be likened to four stages of life: the tender early flowers of Spring to innocent childlife: the gay blossoms of May and June, with all their fruitful promises, to advancing youth; the ripening fruit of summer's prime, to mature manhood in its strength and perfection; while the white flowers and hoary leaves of our Pearly Everlastings and drooping Grasses are not inapt emblems of old age, bending earthward yet not destroyed, for they have winged seeds that rise and float upwards and heavenwards, and we shall again behold them in renewed youth and beauty. 


\section{NATIVE WILD FLOWERS}

\section{EARLY-FLOWERING EverLASTING-Antennaria dioica (Gaertn.).}

Our earliest Everlasting is a pretty low creeping plant, not exceeding six inches in height, with small round clustered heads of downy whiteness, with dark brown anthers, which resemble the antennæ of some small insect, whence the generic name Antennaria is taken. The leaves. of the plant are white beneath and slightly cottony on the outer surface, becoming darker green during the summer. The rootstock is spreading, the leaves numerous, roundishspatulate. The whole plant has a hoary appearance when it first springs up.

This modest, innocent-looking little flower peeps forth in April and carpets the dry gravelly hills with its downy blossoms and soft silken leaves, sharing the newly uncovered earth with the Blue Violet (Viola cucullata), and early pale yellow Crowfoot, Rock Saxifrage and Barren Wild Strawberry (Waldsteinia fragarioides-Tratt), which is then beginning to put forth its new foliage and yellow flowers, that have been kindly sheltered by the persistent leaves of the former year, now red and bronzed by the frosts of early spring. Our pretty Canadian Everlasting bears some family resemblance to the far-famed "Edelweiss" of the High Alps (Leontopodium alpinum). As in that flower, the clustered heads are set round the centre of the disc, like a little infant family surrounding the careful mother.

In the singular Alpine species the whole plant, from root-leaves to stem and involucre, is thickly clothed with snow-white down, as if to keep it warmly defended from the bitter mountain blasts and whirling showers of snow and 
hail. Thus does Creative Love shield and clothe the flowers of the field; His tender care is over all His works.

Scarcely has our little Everlasting raised its soft cottony head above the short turf when another species appears, as if to rival its tiny brother, and known as the

Plantain-leaved Everlasting-Antennaria plantaginifolia (Hook.).

This plant varies in height from six inches to eight or nine. The woolly stem is clothed with narrow leafy bracts; the root-leaves are large and broadly ovate, several-nerved, very white underneath, and less downy on the outer surface; the corymbed head of flowers shines with bright scales and silky pappus-the scales are not pure white, but with a slight tinge of brown. Later on in the month of July a tall slender form of this Everlasting may be seen, with larger root-leaves and loose heads of flowers on long footstalks; the flowers are slightly tinged with reddish-purple and silvery-gray, which gives a pearly or prismatic effect as the eye glances over a number of the plants moved by the summer wind. The flowery heads are conical, the unopened blossoms sharply pointed-the whole plant tall, slender and simple, and very downy. *

The later plants of the Everlasting family differ from the above species. One commonly called

Neglected Everlasting-Gnaphalium polycephalum (Mx.), deserves our especial notice on account of the pleasant fragrance which pervades the gummy leaves as well as the shining straw-colored flowers; the scent is aromatic and slightly resinous. This plant is found in old pastures and

* Antennaria neodioica, Greene. 


\section{NATIVE WILD FLOWERS}

by wayside waste lands, often mingled with the Pearly Everlasting (Antennaria margaritacea) and other common species of the order.

It is so commonly seen and so little cared for as to have obtained the name of Neglected Everlasting. Truly even a flower may be without honor in its own country:

There is another plant of this family, found in old dry pastures, with straw-colored shining flowers; but it lacks the aromatic fragrance and dark-green narrow revolute gummy leaves of the preceding; it is branching with a widespread corymbed head and has the leaves decurrent on the stem, whence its name $G$. decurrens. This is an earlier species than the Neglected Everlasting.

\section{Pearly Everlasting-Antennaria margaritacea (Hook.).}

The abundance of the common Pearly Everlasting induced many of the backwoods settlers' wives to employ the light dry flowers as a substitute for feathers in stuffing beds and cushions; and very sweet and comfortable these primitive pillows and cushions are, as well as pleasantly fragrant, for the Pearly Everlasting is also sweet-scented, though not so much so as $G$. polycephalum; the heads are soft, elastic, and easily obtained. The French peasants still hang up wreaths or crosses of the white-flowered Everlastings in churches and upon the graves of the dead, to mark where one fair bud or blossom has dropped from the parent tree to mingle with its kindred dust. It is a fond old custom which time and the world's later fashions have not yet changed among the simple habitants.

Surely we may say with the sweet poet:

"They are love's last gift,

Bring flowers-pale flowers." 
YelLow CoLtsfoot-Tussilago Farfara (L.).

A large proportion of our flowers of midsummer and Autumn are of the Composite Order, but in the spring they are rare, with a few exceptions such as the Earlyflowering Everlasting, the Fleabanes and the Coltsfoot.

The first flower that blossoms is the Coltsfoot (Tussilago Farfara-L.), which breaks the ground in April with its scaly leafless stem and single-headed orange-yellow rayed flower. It is a coarse, uninteresting plant, not common excepting in wet clayey soil; seldom found in the forest. It is the earliest plant of the Canadian spring and prized on that account and for its medicinal virtue, real or imaginary. Both flower and leaf are larger than the British species, but its habits are similar.

In July, August and September our rayed flowers predominate, especially in the two latter months; it is then, when the more delicate herbaceous flowers are perfecting their seeds, that our hardy Sunflowers lift up their showy heads and seem to court the glare of the summer sunshine; it is then that we see our open fields gay with Rudbeckias, Chrysanthemums, Ragworts, Goldenrods, Thistles and Hawkweeds. In the forest we find our White Eupatoriums, Prenanthes and Fireweeds. On all waste and neglected spots the wild Chamomile abounds, as if to supply a tonic for agues and intermittents. The beautiful Aster family may now be seen in fields, by waysides, on lonely lake-shores, in thickets, on the margins of pools and mill-dams, or waving its graceful flowery branches on the grassy plains and within the precincts of the forest. There are species for each locality-white, blue, purple, lilac, pearly-blue-with many varieties of shade, height and foliage; some species graceful, bending, and spreading, others stiff, upright and 
coarse; but the species are numberless and their habits as various. The most elegant are the Aster cordifolius (L.), and A. puniceus (Ait.); the most delicate the little white shrubby Aster (A. multiflorus-L.), with reddish disc and golden-tipped anthers, which give a lovely look to the crowded small white-rayed flowers, as if they were spangled with gold-dust. On dry gravelly banks near lakes and streams is the favorite haunt of this pretty Aster. The plant is much branched, the branches growing at right-angles to the stem, crossed with narrow leaves, and bearing an abundance of small daisy-like blossoms. On the springy shores of ponds and the banks of low creeks an upright single-headed Aster (A. astivus) may be seen, with bright azure rays and yellow disc, together with a tall woody-stemmed, flat-topped, coarsely-rayed white species, Diplopappus umbellatus (T. \& G.). The large-flowered, branching, many-blossomed, purple-rayed Asters are chiefly found in dry fields, by wayside fences, and among loose rocks and stones, giving beauty where all else is rough and unsightly, making the desert to blossom as a garden.

\section{CONEFLOWER-Rudbeckia hirta (L.).}

\section{(PLATE VII.)}

The Coneflower is one of the handsomest of our rayed flowers. The gorgeous flaming orange dress, with the deep purple disc of almost metallic lustre, is one of the ornaments of all our wild open prairie-like plains during the hot months of July, August and September. We find the Coneflower on sunny spots among the wild herbage of grassy thickets, associated with wild Sunflowers, Asters and other plants of the widely diffused Composite Order.

Many of these compound flowers possess medicinal qualities. Some, as the Sow-thistle, Dandelion, Wild 


\section{STUDIES OF PLANT LIFE}

Lettuce and others, are narcotic, being supplied with an abundance of bitter milky juice. The Sunflower, Coreopsis, Coneflower, Ragweed, and Tansy contain resinous properties.

The beautiful Aster family, if not remarkable for any peculiarly useful qualities, contains many highly ornamental plants. Numerous species of these charming flowers belong to our Canadian flora, lingering with us

"When fairer flowers are all decayed,"

brightening the waste places and banks of lakes and lonely streams with starry flowers of every hue and shade-white, pearly-blue and deep purple.

The Coneflower is from one to three feet in height, the stem simple or branching, each branchlet terminating in a single head. The rays are of a deep orange color, varying to yellow; the leaves broadly lanceolate, sometimes once or twice lobed, partly clasping the rough hairy stem, hoary and of a dull green, few and scattered. The scales of the chaffy disc are of a dark shining purple, forming a somewhat depressed cone. This species, with a slenderer-stemmed variety with rays of a golden yellow, are to be met with largely diffused over the Province.

Many splendid species of the Coneflower are to be found on the wide-spread prairies of the West, where their brilliant starry flowers are mingled with many a gay blossom known best to the wild Indian hunter and the herb-seeking Medicine-men of the native tribes, who know their medicinal and healing qualities, if they are insensible to their outward beauty. One tall purple-rayed species (Echinacea purpurea) is very handsome.

I sometimes think that, though apparently indifferent to the beauties of Nature, our laborers are not really so 


\section{NATIVE WILD FLOWERS}

unobservant or apathetic as we suppose them to be; but that, being unable, to express themselves in suitable language, they are silent on subjects concerning which more enlarged minds can speak eloquently, having words at their command. The uneducated know little of the art of word painting in describing the beautiful or the sublime.

\section{Spice Wintergreen-Gaultheria procumbens (L.).}

This pretty little plant has many names besides the one above: it is also known as Teaberry, Checkerberry and Aromatic Wintergreen; but it shares these English names with many other forest plants.

The aromatic flavor of its leaves and berries has made the Spice Wintergreen a favorite, not with the Indians only but also with the confectioners, who introduce the essential oil that is extracted from the leaves and fruit into their sugar confections. It is also an ingredient in many of the tonic and alterative bitters prepared and sold by the druggists in Canada. The squaws chew the dry, spicy, mealy berries when ripe with great relish; and in the lodge the Indian hunter smokes the leaves as a substitute for tobacco, for when burnt they give out a pleasant aromatic smell. The leaves are warm and stimulant, agreeable to the taste and perfectly wholesome.

The creeping root-stock throws up simple upright stems at intervals, crowned with a few smooth thick shining leaves of a bright green color. The flowers are three or four in number, resembling in form the Arbutus, Heath, Huckleberry and others of the family, being a roundish bell, contracted at the neck, pale white or flesh-colored. The fruit, which is persistent through the winter, is of a brilliant scarlet. The fleshy calyx is of the same texture and color 
and forms a part of the edible berry. The habit of the plant is evergreen, and it may be found on sandy knolls, in thickets, and under the shade of bushes in oak-openings; a finer, larger form is also to be met with in the forest, in cedar swamps, the leaves, fruit and flowers being nearly twice the size of the above. The leaves are strongly revolute at the edges, very smooth and shining.

There is nothing that we cling to with fonder affection than the flowers of our country, especially such as in childhood we delighted to gather. Thus the daisy, primrose and violet of England and Ireland and the bonnie heather and harebell of old Scotia are dear to the heart of the emigrant, and the sight of one of these beloved flowers, cherished in a garden or greenhouse, will awaken the tenderest emotions. An old Scotchwoman when asked how she liked Canada replied, "Ay, nae dout it's a gude land for food and for the bairns, but there is nae a bit of heather or ae bonny bluebell in a' the lan'. It's nae like my ain country."

When shown a bunch of harebells which I had gathered fresh from a gravelly bank, she grat (wept) at the sight of them. "To see," she said, "the bonnie wee things once mair before I die!"

I was once touched by the rapture, even to tears, of a Swiss nurse who, on seeing some flowers of the Alpine Ranunculus growing in the garden of Tavistock Square, flung herself on the grass beside them and kissing each blossom cried out, "Ah! fleur de mon pays!" (Ah! flower of my country!)

The brilliant scarlet berries of several of the shrubby little Wintergreens, forming so gay a contrast to the dark glossy foliage, render them very attractive. 


\section{NATIVE WILD FLOWERS}

On dry rocky hills we find the Box-leaved Wintergreen or Bearberry (Arctostaphylos Uva-ursi-Spreng.), which clothes the dry rocky and gravelly hills all through the continent of North America, is found far to the north, even in barren Labrador, and on the rocky slopes of the far-off Hudson's Bay. It abounds far north in Norway, and clothes the ground with its spreading branches. As winter approaches the dark green leaves assume a purplishbronze hue, which is enlivened by the bright red berries. These pretty evergreens might be adopted as a substitute for the holly by such as care to keep up the old custom of dressing the house with green boughs at Christmas-tide in honor of the birthday of the Saviour. Might not the primitive Christians have intended by these emblems to keep faith, hope and charity ever green within the church and homestead.

A deeper meaning often lies in the old usages of our forefathers than we are willing to acknowledge in this our day of cotton-spinning and gold-digging, railroads and electric telegraphs.

\section{RatTlesNake Root-Nabalus albus (Hook.).}

This tall stately-growing plant belongs to the same natural order as the Lettuce, and, like it, abounds in a bitter milky juice which pervades the thick spindle-shaped root, the leaves and stem, even to the pedicels of the graceful nodding pendent flowers.

The plant, applied both externally and internally, has long had the reputation of being an antidote for the bite of the Rattlesnake.

The slender ligulate corollas which surround the cinnamon-colored pappus are beautifully striped with purple and creamy white; the pointed tips are turned backwards 
in the full-blown flowers, displaying the stamens and pistils and soft woolly pappus. The clustered flowers, on slender footstalks, droop very gracefully at intervals on the stem, which with the branchlets have a purplish tinge.

In the variety Serpentaria this color pervades the whole plant to a greater degree, and the leaves are more deeply divided than in the type.

In damp rich woods we often find a slender, delicate species which is commonly called

\section{LiON'S-FOOT-Nabalus altissimus (Hook.).}

The plant is from two to three feet high; leaves light green, thin, coarsely toothed and widely lobed. The strapshaped flowers are narrow, pointed and revolute; the scales are of a pale green, the pappus of a beautiful fawn color. The elegant yellow drooping flowers, in clusters, make this forest plant a very attractive object.

The above plant was pointed out to me as the true Lion's-foot by an old Yankee settler, and I have retained the name, though it does not quite correspond with Gray's plant, so called. Gray's Lion's-foot is also known as Gall of the Earth, from the intense bitterness of its root; possibly all these bitter milky-juiced plants are narcotics, but as yet not recognized unless by the unlearned Indian or the old herbalist of some remote backwoods settlement where doctors and druggists were unknown and the herbs of the field were the only medicaments-generally administered by an old woman famed more for her herb decoctions and plasters than for her wisdom in book-learning, who believed that there was a salve for every sore and a potion for every ailment under the sun if the folk had but faith to believe in her "yarbs." 

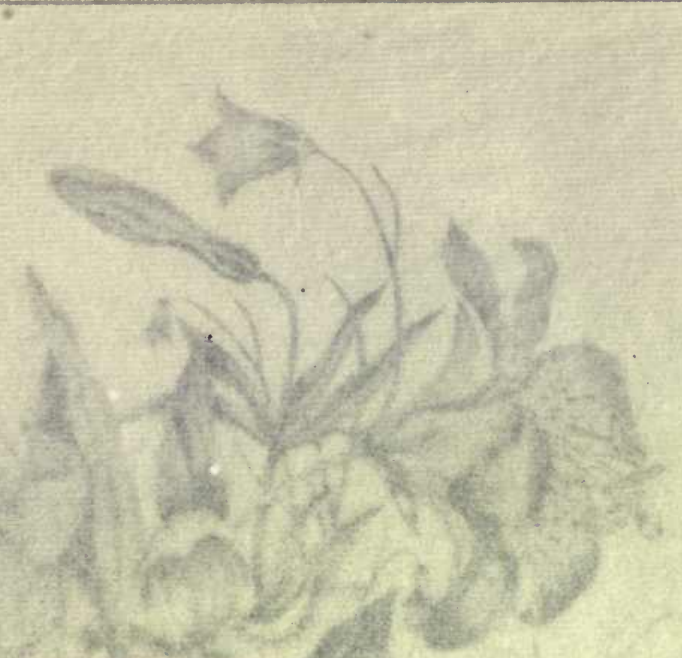

\section{PLATE XIII.}

1. Showy Lady's Slipper (Cypripedium spectabile). P. 45.

2. Harebell (Campanula rotundifolia). P. 80.

3. Wild Orange Lily (Lilium Philadelphicum). P. 78.

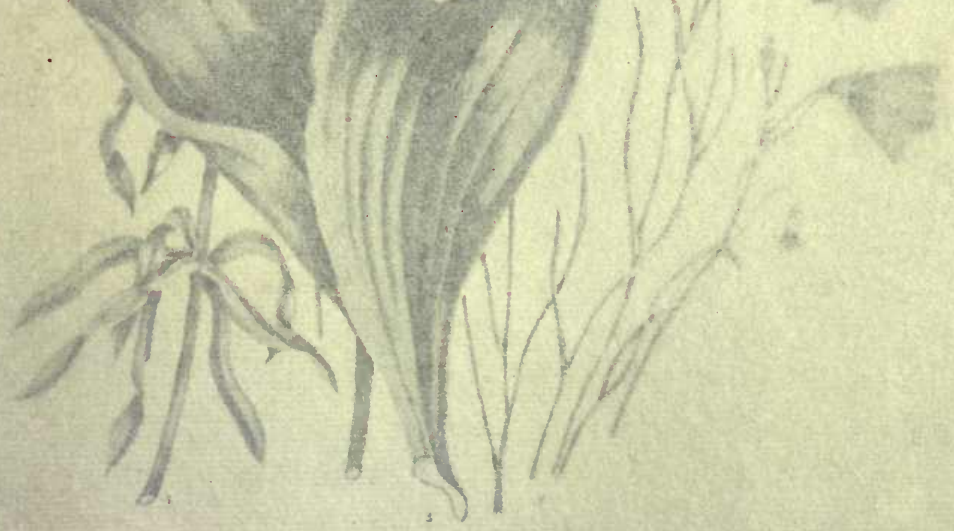


in the full-blown flowers, displaying the stamens and pistils and soft woolly pappus. The clustered flowers, on sleader footstalks, droop very gracefully at intervals on the stem, which with the branchlets have a purplish finge.

In the variety Serpentaria this color pervades the whole plant to a greater degree, and the leares are. more deeply divided than in the type.

In damp rich woods we often find a slender, delicate gpecies which is commonly called

LION's-FOOT-Nabalus altiessensit (Hook.).

The plant is from two ter thita shet high; leaves light green, thin, coarsely troolind and wlyty lebod. The strapshaped flowers are narron, IIIX aTA molate; the scales are of a pale green, $\quad$.IIX $\exists T A J 9$ atifnl fawn color.

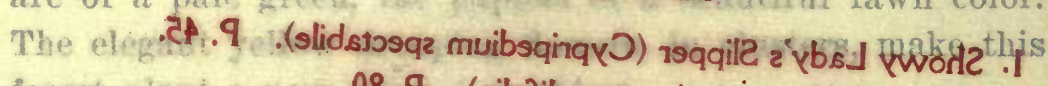
forest plint a .08 .9 . (silotibnusor slunsqms)) llsdszsH .S

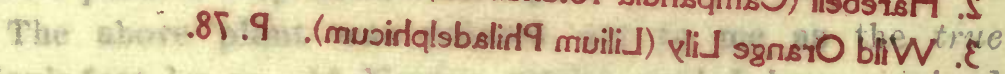

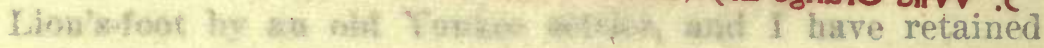

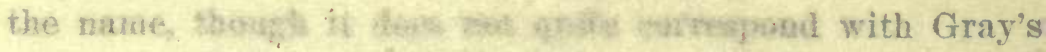

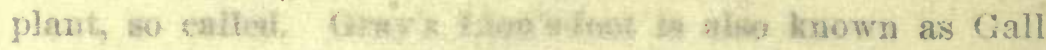
of the Earth, foos lik dritand bitutaess of its root; possibly all these butzat achescystend plents are narcotics, but as yet not recogratud andows in the unlearned Indian or the old herbalist of sobsis manats hackwoods settlement where doctors and druggists were woknown and the herbs of the field were the only medicaments-generally administered by an old woman famed more for her herb decoetions and plasters than for her wisdom in book-learning, who believed that there was a salve for every sore and a potion for every allment under the sun if the folk had but faith to believe in ler "yarbs." 


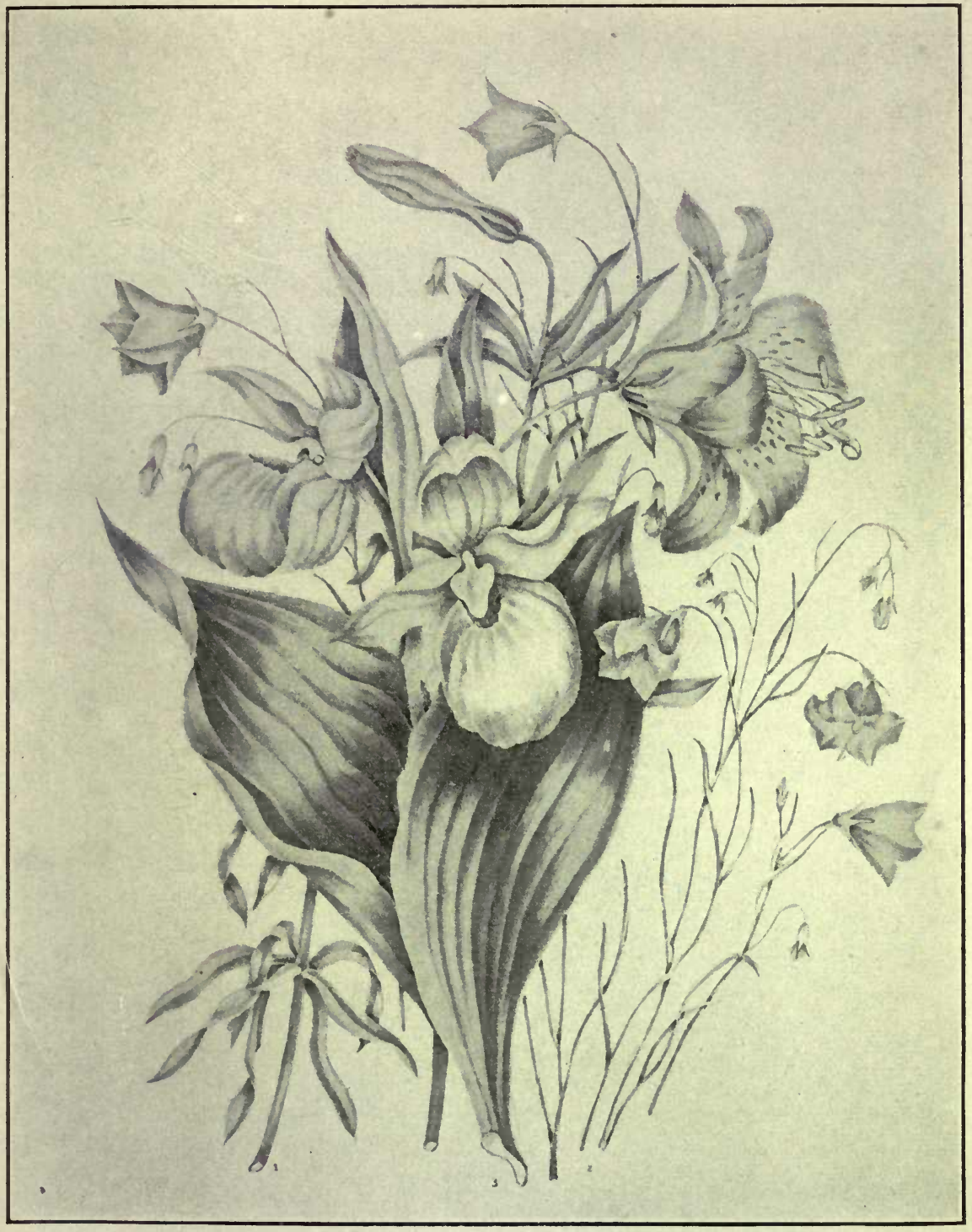





\section{NATIVE WILD FLOWERS}

\section{THOROUGHWORTS.}

There is a popular belief among many of our native herbalists that for every disease that man is subject to God in His mercy has provided a certain remedy in the herbs of the field and trees of the forest; that there is a sovereign virtue in roots and barks and leaves and flowers. if man will but search them out and test their qualities.

The use of "simples," as the vegetable medicaments used emphatically to be termed, has always found advocates in the lower classes, especially amongst the humble countryfolk, who dread mineral medicines, with the nature of which they are totally unacquainted-preferring the herbs of the field, which they see growing about them, to the more costly "doctor's stuff," as they call the prescriptive medicines of the physician. To the herb doctor they apply with every confidence, entertaining no fear of the vegetable poisons in which he often deals; in his skill they have unlimited faith.

Much of this kind of knowledge is possessed by the old Canadian and the Yankee settlers, hardy pioneers who emigrated from the United States at the close of the Revolutionary War, induced by the promised reward of certain grants of land in return for their professed or actually proved attachment to the British Government. These families, under the appellation of U. E. or United Empire Loyalists, spread themselves along the then unbroken forests on the shores of the St. Lawrence, and bore hardships and privations of which there are few parallel cases.

Dwellers in the lonely leafy wilderness, with no road but the rushing river or broad-spread sea-like lake, they lived apart from their fellow-men; self-dependent, they relied 
upon their own ingenuity and personal exertions for the actual necessaries of life. The men supplied the household with game from the forest (it was over-plentiful in those days) and fish from the lakes and streams; while in clearing the land, and cultivating it in the rude fashion of the time, the women and children, without respect of age and sex, did their part. On the females depended the manufacture of every article of clothing; the loom occupied a prominent place in the log house, and the big spinningwheel occupied the "stoop" in summer.

Occasionally a few families, bound together by ties of love or interest, wisely formed a colony and lived within a reasonable distance from one another; but more commonly, their grants comprising many hundreds of acres, according to the number of persons in one household; the settlers were thrown far apart. A blazed path through the forest was their only means of communication by land, and this often interrupted by rapid unbridged streams or impenetrable cedar-swamps.

In case of accidents, such as wounds from axes, broken limbs, and such ailments as agues and fevers, necessity compelled active measures to be adopted on the spot; of medical practitioners, so called, there were none; the broken limbs were set by those in the settlement possessed of the most nerve, while the elder women bound up the wounds or gathered the healing herbs which they had learned to distinguish by experience, or from oral tradition, as being curative in certain disorders. Something of this healing art was derived from their ancestors, who had the knowledge from the Indian medicine-men; and some remedies were, no doubt, discovered by chance-a happy thought seized upon and put into practice in some desperate case, where the chances of life hung upon something being done to relieve the sufferer. 


\section{NATIVE WILD FLOWERS}

To these simple people, no doubt, we owe many of the significant local names by which our native plants are still distinguished, and which will always be adopted when speaking of them in familiar parlance. Occasionally we pause and ponder on the source whence such a name as Boneset, for Eupatorium perfoliatum (Li.), has been derived. We can only surmise that the powerful virtues of the plant are serviceable, in cases of dislocations and fractures, in reducing fever and causing a more healthy action of the blood, thus accelerating the return of strength to the injured limb.

The sanative qualities of these plants are no new discovery, nor are the medicinal properties confined to one species alone; some are used in curing the bites of snakes, as $E$. ageratoides (L.), and an infusion of the leaves of another species is an excellent diet drink; almost all are sudorifics and tonics.

The genus Eupatorium is dedicated to Eupator Mithridates, who is said to have used a species of the genus in medicine. Several species of these homely plants are used in fevers and intermittents by the herb-doctors and Indians.

The tallest and most showy of the Eupatoriums is

\section{TruMPETWEED-THOROUGHWORT-E. purpureum (L.).}

The flowers, in dense corymbs, are of a deep flesh-color, approaching to red; leaves shining, coarsely veined, narrowing to a point, the upper ones much narrower, mostly growing in whorls round the stout stem. The plant has a bitter, somewhat resinous scent when the leaves are bruised. This tall Thoroughwort is abundant on the banks of creeks and in marshy places, where it often reaches the height of five or six feet. 
The red-flowered Eupatorium, the old Thoroughwort of the English herbalists, closely resembles our Canadian plant; its habits, colors and qualities seem the same. When viewing the native species it appears to carry my thoughts back to childish haunts on the banks of the clear-flowing . Waveney and the flowery Suffolk meadows,

"Where in childhood I strayed,

And plucked the wild flowers that hung over the way."

A more graceful member of the Eupatorium family is the

White Snakeroot-Eupatorium ageratoides (L.),

which is a pretty, elegant, perennial plant found in rich woods. The white flowers are borne in compound corymbs.

The leaves are from two to three inches long, toothed, narrowly pointed, on long stalks, and of a bright green, smooth and thin. Our plant is about three feet high, wide and loosely spreading. The pretty white corymbs of flowers make this an attraction among the forest herbage, for at the season when it is in bloom most of the flowers have disappeared from the woods.

Not unfrequently we find in damp woods, but more especially on open marshy ground, the well-known herb.

\section{BONESET-Eupatorium perfoliatum (L.).}

This species is easily distinguished from any other by its veiny hoary grayish-green leaves, united at the base around the stem, or perfoliate, the stem of the plant passing through the centre of each pair. The large closely-set corymbs of flowers are of a greenish-white and want the pretty tasselled appearance of the White Snakeroot (E. ageratoides). The scent of this more homely plant is strongly resinous and bitter, but it is held in great esteem for certain qualities of 


\section{NATIVE WILD FLOWERS}

a tonic and anti-febrile nature, and it forms one of the old remedies for ague and fever.

In evidence of the value of the herb Boneset, Pursh gives a practical illustration from his personal experience of the efficacy of its medicinal properties. He says:

"The whole plant is exceedingly bitter, and has been used for ages past by the natives in intermittent fevers; it is known by its common names, Thoroughwort and Boneset. During my stay in the neighborhood of Ontario, when both influenza and lake fever were raging, I saw the benefit arising from the use of it, both as regarded myself and others. It is used as a decoction, or, as I considered more effectual, as an infusion or extract in rum or gin." (Vide Pursh's Flora America Septentrionalis.)

\section{MAYWEED-Maruta Cotula (DC.).}

"The traveller passes by

With reckless glance and careless tread, Nor marks the kindly carpet spread

Beneath his thankless feet.

"So poor a meed of sympathy

Do gracious herbs of low degree

From haughty mortals meet."

-Agnes Strickland.

This is one of our commonest weeds, intruding itself into the very streets and by-lanes of our villages, but never welcome there, as it gives out a nauseous bitter scent at dew-fall. The more sunny the place and the drier the soil the more does this hardy plant flourish; it heeds not the trampling feet of man or steed, but rises uninjured from the tread of the passer-by, cheerful under all persecution, despised and disregarded as it is. If we look closely we see beauty in the finely cut and divided foliage and the ivory- 


\section{STUDIES OF PLANT LIFE}

white daisy-like flowers which appear all through the summer; but when seen in dirty streets we overlook its merits and turn from it with distaste. This feeling is not very amiable, but it is natural to dislike whatever is vulgar, low and intrusive.

\section{WiLd Sunflower-Helianthus strigosus (L.).}

"As the sunflower turns to her god as he sets The same look which she turned when he rose."

-Moore.

So sings the Irish bard, but I rather fancy it is a poetical illusion, for I have watched the flowers and never could convince myself of the fact. However, we may hope that as the Sunflower has become so fashionable an ornament in the present day, some of its devoted lovers will strive to ascertain the truth of the tradition.

As a not very graceful badge of the votaries of rstheticism, we see the garish orange Sunflower worn in hats and bonnets, as ornaments for breast and sleeves, and reproduced in needle-work and other ornamental designs for the boudoir or drawing-room. Rows of the gigantic flowers may now be seen lolling their jolly heads in gardens and lording it over the humbler and lowlier blossoms.

We have many flowers of this wide-spread tribe of plants extending through the country wherever the soil and surroundings are favorable to their growth; especially may different members of these rayed flowers be found on dry plains, in open copse-woods, and on the banks of streams where the soil is sandy or gravelly.

So numerous are the varieties that it would be tedious to enumerate them. One of the handsomest is $H$. strigosus (L.). The Sunflowers form one of the distinguishing floral ornaments of the Canadian plains and of the extensive 


\section{NATIVE WILD FLOWERS}

prairies of the North-west, where miles of Sunflowers, Rudbeckias, Liatris and other gorgeous flowers-blue, white, red-may be seen all through the hot summer months, the orange and yellow stars of the Helianthus tribe above all conspicuously apparent.

The garden Sunflower may often be met with within the forest, the seed having been carried by the ground-hog or squirrel and dropped on the road. I have seen little piles of the ripe seed of the garden Sunflower lying on stumps and rails to dry, the industrious little gleaners depositing them in such places to be hoarded at their convenience in their granaries. The same thing may be noticed during the harvest-time near the wheat-fields. I have watched with no little curiosity the heaps of wheat left by these little innocent gleaners, and have seen them come with their companions to fetch away their newly-threshed stores, having first carefully destroyed the germs. Who taught the squirrel this latter wise precaution to prevent the germination of the grain?

Many years ago, while living on a wild lot on the Rice Lake, my son, in digging the ground for the construction of a root-house, discovered a granary of a squirrel, or it might be of a ground-hog, the Canadian marmot. A large supply of Indian corn, beech-nuts and acorns was stored many feet below the surface of the dry sandy soil; but the eye or germ had been carefully bitten out of each one.

\section{Dandelion-Taraxacum Dens-leonis (Desf.).}

The Composite Order presents us with more numerous families of plants than any other, and supplies us with a host of fiowers, and also some troublesome weeds, which are of wide diffusion, the winged seeds being borne to great 
distances and establishing themselves wherever they chance to alight. Many an unnamed flower exists, no doubt, in secluded spots where as yet the foot of man has never trod. Those primitive wilds where even the hardy lumberman's axe has never been heard, those rugged hills known only to the eagle and the falcon, those deep cedar swamps that afford shelter to the wolf, the bear and the wildcat, conceal many a graceful shrub and rare plant that one day may be gazed on with admiring eyes by the fortunate naturalist, whose reward may possibly be to have his name conferred upon the newly-discovered floral treasure.

A large number of plants of the Composite Order are remarkable for the bitter milky juice contained in the leaves, stalks and roots, the properties of which are narcotic and sedative. This bitter milky juice pervades all parts of the Dandelion or Taraxacum; also the Wild Endive and other members of the Lettuce tribe.

The Dandelion is so well known that it is unnecessary to enter into any description of its floral parts. The root of the Dandelion has been utilized as a substitute for coffee; in preparing it the root should be washed thoroughly, but the thin brown skin not scraped off, as much of the tonic virtue is contained in this brown covering of the root. This must be cut up into small pieces and dried by degrees in the oven until it becomes dry and crisp enough to grind in the coffee-mill; it is then used in the same way as the coffeeberry, with the addition of milk and sugar. A small portion of fresh coffee would, I think, be an improvement to the beverage, but it is not usually added. Many persons have used this preparation of the Dandelion and greatly approved of it. It is a good tonic and very wholesome. The herb itself, if the leaves be blanched, makes a good salad, equal to the garden Endive. 


\section{NATIVE WILD FLOWERS}

\section{Punslane-Portulaca oleracea (L.).}

This is one of the troublesome weeds of our gardens, and one would hardly associate it with the brilliant showy flower of our borders. We must, however, recognize it as a near relation. The original of the cultivated Portulaca of our gardens is $P$. grandiflora, from South America, whence it was introduced some years ago. Even in its wild state, or on its native prairies, it is a strikingly attractive flower, claiming the admiration of the beholder; but our humbler species is regarded as a thing of naught. The simple Purslane, however, has its virtues, and we will try to rescue it from being utterly despised by showing how it may be utilized. When the plant first appears it pushes forth small wedge-shaped succulent leaves, of a dull red color, and soon spreads over the ground, branching at every thickened joint. If the soil be rich it becomes very luxuriant, and being very tenacious of life, it is difficult to get rid of it, as it springs again from the joints, flourishing the more vigorously from the persecution it has undergone. The axil of every joint is furnished with a small sharply-pointed red bud. The flowers are small, pale yellow, opening in sunshine; the pod many seeded, with a little round lid that covers the top of the capsule.

The soft, oily mildness of the leaves and stalks of this plant renders it useful as an application, crushed or steeped in hot water or milk, for inflammatory tumors. I have seen it also recommended as a pot-herb for the table-in fact, it is largely grown in France for that purpose; I have also. heard it said that it may be used as a dye, but that the blue color produced is very evanescent.*

* I cooked it for greens and found it very nice.-A.D.C. 


\section{STUDIES OF PLANT LIFE}

\section{Wild Bergamot-Monarda fistulosa (L.).}

Among the Mints we have many different species, all odorous, pungent and aromatic; some have pretty flowers, but generally speaking they are more valued for their qualities than chosen for any striking beauty of color in the blossoms. We have Spearmint, Peppermint, Horsemint, Catnip and many others of this humble but not useless family.

The plants of the Natural Order Labiatæ are remarkable for being mostly aromatic and pungent; although some are coarse and rank in odor, none are hurtful.

One of the handsomest and most agreeable in scent is the tall Monarda or Wild Bergamot, a very handsome sweetscented plant, common upon our oak-openings and wild grassy plains and dry uplands. I have seen a very pretty variety-Monarda fistulosa (L.), var. mollis (Benth) -with rose-colored blossoms and glandular flowers, from the Poplar Hills, Manitoba. The species so commonly seen on the hilly ground above Rice Lake-Monarda fistulosa (L.) -is tall, with soft leaves of a dull green, of a fine aromatic scent and velvety surface; the globular heads of the lilac-lipped flowers are terminal; the color of the corolla varies from lilac to very pale pinkish-white.

All the species are sweet-scented and might be utilized to advantage as an aromatic flavoring, the Bergamot being far more delicate and agreeable than the Wintergreen which is so largely used in confections.

\section{HealaLL_Prunella vulgaris (L.).}

This simple herb is commonly found in grassy meadows and on wayside waste-lands, near rivers and low grounds. It is common everywhere, yet it is generally thought to be an 


\section{NATIVE WILD FLOWERS}

exotic, having been introduced among foreign grasses and thus become naturalized to the country.

There seems to be really no special virtue in the plant; though it boasts of a name which should entitle it to notice, yet we are ignorant of its medicinal or healing uses. It is destitute of any sweetness, but the blossoms are pretty and associated with English meadows and green bowery lanes, so we look kindly upon the purple-lipped flower for the dear Old Country's sake.

\section{Common Mullein-Verbascum Thapsus (L.).}

This plant is one of the tallest of our wayside weeds; the large soft leaves, densely clothed with silky white hairs, are not considered without value by the herb-doctors. They are used in pulmonary disorders, as outward applications for healing purposes, and in such complaints as dysentery, to allay pain; the leaves are made hot before the fire and so laid over the body of the sufferer. Moreover, this wonderful plant, if laid in cellars or granaries, is said to drive away rats and mice; but this virtue may be only a fond delusion. Commend me rather to Miss Pussy as a more certain exterminator of these troublesome household pests. A grand and stately spike of golden flowers, called Giant-taper, grew in my father's garden, and was the resort of honey-bees innumerable. Homely as our Canadian plant is considered to be, yet it has uses of its own besides those attributed to it by the old settlers. The abundance of the seeds, which remain in the hard capsules during the winter, afford a. bountiful supply of food for the small birds that come to us: early in Spring. In March, and early in April, the snowbirds and their associates, the little chestnut-crowner, sparrows,

"That come before the swallow dares," 
and the brown song sparrows, may be seen eagerly feasting on the dry seeds which still remain on the withered plants. Later on, in May and June, the soft gray down of the hoary leaves is used as lining for the nests of the humming-birds and other small birds that weave dainty soft cradles for the tiny families that need such tender care. Taught by unerring wisdom, each mother-bird seeks its most suitable material, and appropriates it for the use and comfort of its unknown, unseen brood. Let us not despise the common Mullein, for may it not remind us of Him who careth for the birds of the air, and giveth them from His abundant stores their meat in due season, and that wonderful unerring wisdom that we call instinct. "Who least, hath some; who most, hath never all."

False Foxglove-Gerardia quercifolia (Pursh). (PLATE XII.)

I think old Gerarde, the first English writer on the wild flowers and native plants of England (for whose memory all botanists feel a sort of veneration), would have given a far better description of the stately plant honored by his name than the writer of this little work can hope to do, seeing that the only native species that has come within her knowledge is a slender purple-flowered Gerardia, $G$. purpurea, which grows on the margin of Rice Lake, among wild grasses and other herbage.

It has been said by one who was a diligent botanist and naturalist (the late Dr. G. G. Bird), that no Gerardias were found north of the Great Lakes, but all were confined to the Western and Eastern States; this, however, was a mistake. At that date very little was known of the Canadian Flora. It was the trying time of pioneer life in the backwoods, when little heed was taken of the vegetable productions of 


\section{NATIVE WILD FLOWERS}

the country. Even the trees of the forest were hardly distinguished by name, and much less were the wild flowers cared for, unless some of the settlers knew of curative medicines to be extracted from the leaves or roots, or of some household dye for the home-spun flannel garments which were then all that could be obtained as clothing for their families.

But to return to my Gerardias, several fine species have been found growing on the islands of Lake Ontario and on the banks of the Humber, that fruitful wilderness of many flowers; and doubtless these handsome, showy plants are well known in many localities westward in the Dominion of Canada.

The handsomest of all is $G$. quercifolia, Oak-leaved Gerardia, a robust, stately plant of from three to six feet in height, with large open-throated orange bells; it is known as False Foxglove. There are several fine purple-fiowered species, and others of paler yellow than quercifolia, with stems coarse, rigid, downy or bristly; the leaves are mostly rough on the surface and of a dull green.

I am not aware of any particularly useful qualities attributed to this genus, but as ornaments to our gardens they would prove very attractive-one of the most suitable is G. pedicularia, a very much branched species which grows in dry thickets; it is about two feet high, has prettily lobed foliage, and bears a profusion of yellow flowers. It seems a pity that these beautiful plants should be passed by as only weeds, unnoticed and unvalued.

\section{GaYFeather-Button SNAKEROOT-Liatris cylindracea (Michx.).}

This pretty purple flower is found growing on dry hills, near lakes and rivers, on sandy flats and old dried water- 
courses. The slender, stiff, upright stem is clothed with rigid, narrow, grass-like, dark green leaves, the longest being nearest to the root. The flowers form a long spike of densely-flowered heads; the scales of the involucre that surrounds them are green, tipped with black, and finely fringed; the styles protrude beyond the tips of the corolla. The root is a round corm, about the size of that of the crocus, sweetish and slightly astringent, mealy when roasted, and not unpleasant to the taste. The roots are sought after by the ground-hogs, which animals often make their burrows near the place where the plants abound, which is often on the slopes of dry, gravelly hills; at any rate it is on the sides of ravines, on the dry plains above Rice Lake, and on islands in our chain of back lakes in Burleigh and Smith, where I have found the bright Gayfeather blooming in the hot month of August. The seeds are hairy, almost bristly, of a light sandy brown when ripe. The blossoms, when quite dry, retain their beautiful color, even for many years, and may be mixed with the flowers of the Pearly Everlasting for winter bouquets or ornamental wreaths.

One of the species of this family, $L$. scariosa, a handsome flower found on our North-western prairies, is known by the name of Blazing Star. The showy flowers of the Liatris family, and their hardy habits, make them desirable plants for cultivation. They are easily propagated from seed.

\section{GOLDENROD—Solidago latifolia (L.).}

The Solidagos are among our late August and September wild flowers, coming in with the hot summer suns which have given the ripened grain to the cradle scythe of the harvester. The Trilliums and Lupines and gorgeous Orange Lilies have departed with the Moccasin-flowers, the sweet- 


\section{NATIVE WILD FLOWERS}

scented Pyrolas, and the Wild Roses. Many of the fair flowers have faded and gone, but we are not quite deserted; we have yet our graceful Asters, our pretty Gayfeathers, our Sunflowers, Coneflowers and the blue Gentians, and brightening the waysides with many a gay, golden sceptrelike branch, our hardy, sunny Goldenrods, varying in color from gorgeous orange to pale straw-color, from the tall stemmed S. gigantea to the slender wand-like forms of the dwarf species, of which we possess many kinds, some with hoary foliage, others with narrow willow-like leaves of darker hue. On the grassy borders of inland forest streams we find the Goldenrods; they seem to accommodate themselves to every kind of soil and situation. The rocky clefts of islands are gay with their bright colors, the moist shores of lakes, the sterile, dusty waysides, corners of rail-fences or the forest shades, no spot so rude but bears one or another species of these hardy plants; a coarse but grand genus, and not without its value. Not for ornament alone is the Goldenrod prized. The thrifty wives of the old Canadian settlers prized it as a dye-weed, and gathered the blossoms for the coloring matter that they extracted from them, with which they dyed their yarn yellow or green.

One of the late flowering species, S. latifolia, is remarkable for its fragrance; it is slender in habit, the lax branches trailing upon the ground in grassy woodlands. The leaves are large, very sharply and coarsely toothed, margined on the leafstalk, terminating in a slender point at the apex. The blossoms, which are larger than those of many of the taller species, are clustered in the axils of the large thin leaves at rather distant intervals along the slender branches; the silky pappus of the winged seeds is tinged with purplishbrown, the flowers are golden-yellow. 


\section{STUDIES OF PLANT LIFE}

StrawberRy Blite-INdian StrawberRy-Blitum capitatum (L.).

(PLATE XIX.)

The Strawberry Blite-or, as it is often called, Indian Strawberry-is widely spread over the Northern States and Canada. Wherever the forest has been cleared it is sure to appear, as it seems to affect the rich black leaf-mould of the newly-cleared forest.

It is not indeed found within the close thick forest, but appears wherever a partial clearing has been made. It may be seen close to the rough log walls of the Jumberer's or chopper's shanty, flourishing in great luxuriance under this half culture. On forest land that has been burnt over and left uncropped it may be seen in perfection, and within the garden enclosure, where it becomes a common weed, though truly more ornamental than many a flower that the gardener cultivates with care and trouble.

When fully ripe the long spikes of crimson fruit and the foliage, of a bright green color, have a beautiful appearance, tempting the hand to pluck the richly-colored seed clusters; but beauty is not always to be trusted, and in this case the eye is deceived and the taste disappointed. The fruit is insipid and flavorless, though not unwholesome.

The red juice is used by the Indian women in dyeing, and in old times the backwoods settlers made it a substitute for ink, but unless the color be fixed by alum it fades and disappears from the paper.

The Indian Strawberry, or Blite, belongs to the Spinach family, and may be used with safety as a substitute for the garden vegetable, being perfectly harmless.

I well remember, many years ago, greatly alarming some of my neighbors in the backwoods by gathering the tender leaves and shoots of these plants and preparing them for the 
table. I was assured that death would be the result of my experiment; but I was confident in the innocent qualities of my fruit-bearing Spinach, and laughed at the prediction that I should find death in the pot.

Nor is the Indian Strawberry the only member of the Spinach tribe that is found growing in Canada. We possess several others, among these the herbs commonly known by the country people as Good King Henry (B. Bonus Henricus), which has been introduced from Europe, and Lamb's Quarters (Chenopodium album), which plants are still made use of as spring regetables, though not now in such repute as formerly. Happily few houses, or even shanties, cannot boast of a garden around the dwelling, but many years ago it was a rare thing to see even a cabbage-plot fenced in about the homestead, and the cultivation of flowers was regarded as a piece of useless extravagance, a mark of pride and idle vanity. We do not wish those good old times back again!

The leaves of the Indian Strawberry are thin, long-pointed, somewhat halbert-shaped, with shallow indentations at the edges. They are of a bright lively green color. In the earlier stages of growth, the flowering spikes stand upright, but as the fruit ripens they decline, and are bending or entirely prostrate, much resembling the drooping Amaranth (called Love Lies Bleeding) of our gardens, but more brilliant in hue. The berries of the Indian Strawberry are wrinkled on the surface and dotted over with purplish-black seeds, which lie embedded in the soft fruity pulp of the altered calyx in a manner similar to the Strawberry. The fruit begins to ripen in July, and continues by a succession of lateral branches to bear its red clusters all through August, after which the frosts of September cut it off and destroy the beauty of the plant. 


\section{STUDIES OF PLANT LIFE \\ TuRTLEhEAD-SNaKeHEAD-Chelone glabra (L.).}

(PLATE XII.)

This coarse but rather showy plant is found in damp thickets near lakes and streams. The large white twolipped flowers grow in terminal clusters or spikes; the upper lip projects downward like a turtle's bill; the foliage is dark green, the leaves opposite, the edges coarsely-toothed, long and sharp-pointed; the stem, simple, or widely branching and bushy; the large handsome white flowers are often tinged with red or purplish-red; the blossom is open-throated, somewhat contracted at the mouth by the overhanging of the upper lip. The whole plant is from two to three feet high. The name of the genus is derived from a Greek word which signifies a tortoise, the form of the beaked corolla resembling the head of a reptile; hence also the common name Snakehead, from the fancied likeness to the open mouth of a snake. The flowering season is from July to September; probably under cultivation this flower would become highly ornamental as a large border plant.

There are many very ornamental flowers belonging to the same natural order as the Turtlehead, among which are the Beard-tongue (Pentstemon pubescens), ${ }^{*}$ Monkey-flower (Mimulus), Snapdragon (Antirrhinum), Scarlet-cup (Castilleia), and the Gerardia, with many other plants more remarkable for beauty than for any useful or healing qualities, but very showy in the garden and not difficult of cultivation.

Cardinal Flower-Lobelia cardinalis (L.). (PLATE X.)

One of the most striking of our native flowers is the Red Lobelia or Cardinal Flower. The plant had found its way * See Plate XX. 


\section{NATIVE WILD FLOWERS}

into English gardens as a rarity before I saw it growing in all its wild beauty on the margins of the Otonabee, on my first journey, or rather voyage, up the country. There, growing at the edge of the low grassy flats beside the water, its tall loose spike of deep red flowers fluttering in the breeze and reddening the surface of the bright river with the reflection of its glorious color, this splendid flower first met my admiring eyes.

It was but a short time before that I had seen it cultivated as a new and rare border flower, and here it was in all its loveliness on the banks of a lonely forest stream which then flowed through an almost unbroken wilderness, growing uncared for, unsought for and unvalued. The people, a rude set of Irish settlers, were amused at the delight with which I plucked the flowers. They cared for none of these things; they were to them only useless weeds.

There are several varieties of the Cardinal Flower occasionally found among the wild plants near the inland lakes and creeks of the backwoods, some with flesh-colored corollas, or white striped with red; but these variations are not very common. The prettiest of the blue-flowered plants of the Lobelia family is a small, delicate, branching one, with azureblue and white petals, which is cultivated in hanging baskets, as its bright blue flowers and slender leaves droop gracefully over the pot or basket and contrast charmingly with larger flowers of deeper color and more vivid foliage.

The largest of the North American Lobelias is L. syphilitica, ${ }^{*}$ a stout-stemmed, many-flowered species, which is chiefly found near springs; the flowers are full blue and the spike much crowded; the height about eighteen or twenty inches; leaves light green. The plant seems to flourish in clayey soil near water, and is not often cultivated. Another

* See Plate X. 


\section{STUDIES OF PLANT LIFE}

blue-flowered Lobelia of slenderer habit is $L$. spicata, the leaves growing up the wand-like stem in threes, with intervals between; it has a one-sided look. The spike of flowers is loose and scattered, the leaves very thin, long and narrow, light-green and smooth.

Though by no means so showy-for, indeed, it is a very simple-looking flower-but more remarkable for its uses and medicinal qualities, is the celebrated

\section{INDIAN TOBACCO-Lobelia inflata (L.).}

This plant is much sought after by the old settlers and by the Indian medicine-men, who consider it to be possessed of rare virtues, infallible as a remedy in fevers and nervous diseases. At first it has the effect of producing utter prostration of the nervous system, and is known to be of a poisonous nature. It is, I suppose, a case of " kill or cure."

A decoction of the dried plant relieves fever through the pores of the skin; but though used by some of the old settlers, it should not be administered by anyone inexperienced in its peculiar effects. The Indians smoke the dried leaves, from which fact the common name is derivedIndian Tobacco. They also call the plant Kinnikinic, which, I suppose, means "good to smoke," as the word is also applied to one of the Cornels, as well as to the aromatic Wintergreen, and more generally to the Bearberry (Arctostaphylos) - the leaves of these plants being used as a substitute for the common Tobacco, or to increase its influence when smoking "the weed."

The Indian Tobacco is a small branching biennial, from nine to eighteen inches high; leaves ovate-lanceolate, light green; seed vessel inflated; flowers pale blue, veined with delicate pencilled lines of a darker hue; soil, mostly dry woods or open pastures; nature of this innocent looking herb a virulent poison. 


\section{NATIVE WILD FLOWERS}

\section{INDIAN PIPE-Monotropa uniflora (L.).}

This singular plant has many names, such as Wood Snowdrop, Corpse-plant, and Indian Pipe. The plant is perfectly colorless from root to flower, of a pellucid texture and semitransparent whiteness. There are no green leaves, but instead broad and pointed scales, clasping the rather thick stem, which is terminated by one snowy-white flower. The flower, when first appearing, is turned to one side and bent downwards, but becomes erect as it expands its silvery petals: these are five in number; stamens from eight to ten; stigma about five-rayed; seed vessel an ovoid pod with from eight to ten grooves; seed small and numerous. Though so purely white when growing, the whole plant turns perfectly black when dried; even a few minutes after they are gathered, as if shrinking from the pollution of the human hand, they rapidly lose their silvery whiteness and become unsightly. To see this curious flower in its perfection you must seek it in its forest haunts, under the shade of beech and maple woods, where the soil is black and rich; there, among decaying vegetables, grows this flower of snowy whiteness.

There are two species of the family. In a hemlock wood I found the equally singular

\section{PINe SAP-Monotropa Hypopitys (L.),}

a tawny-colored, scaled, leafless species, with several flowers, covered with soft pale yellowish-brown wool, fragrant, and full of honey, which fell from the flower cups in heavy luscious drops. This plant is of rather rare occurrence; it is found here only in pine or hemlock woods, though Gray speaks of it as common in oak and pine woods. 


\section{STUDIES OF PLANT LIFE}

\section{Gentians.}

"And the blue Gentian flower that in the breeze Nods lonely ; of her beauteous race the last."

This interesting floral family takes its name from Gentius, a king of Illyria, who is said to have been the first to discover and be benefited by its sanative properties. The root used in medicine is, I believe, a native of Spain. The Alpine Gentian-so often spoken of by tourists-is of low stature, with very large intensely-blue upright bells; " a thing of beauty and a joy for ever," even to behold it growing in serene loveliness on the edge of the icy glaciers and rude moraines of the Swiss Alps.

Of all our native flowers the Gentians are among the most beautiful, from the delicately fringed azure-blue (Bryant's flower) to the fair pale softly-tinted Five-flowered Gentian, with its narrow bells and light-green leaves. All are lovely in color and form, but none more deserving of our attention than the large-belled Soapwort Gentian, known also by the poetical name of

\section{Calathian Violet-Gentiana Saponaria (L.).}

This is the latest of all our wild flowers, coming early in the fall of the year and lingering with us

"Till fairer flowers are all decayed, And thou appearest;

Like joys that linger as they fade, Whose last are dearest."

On sandy knolls, among fading grasses and withered herbage of our oak plains, we see the royal deep blue open bells of this lovely flower, its rich color reminding one of a queen's coronation robes. 


\section{NATIVE WILD FLOWERS}

This species somewhat resembles the European G. Pneumonanthe (Linn.), which is also known by the same poetical English name. In Sowerby's "English Botany," under the head of the last named species, we find: "This pretty little plant is worthy of cultivation, and is quaintly mentioned by Gerarde, who says, 'the gallant flowres hereof bee in their bravery about the end of August,' and he tells us that 'the later physitions hold it to bee effectual against pestilent diseases, and the bitings and stingings of venomous beasts.' "

Our Gentians are the last tribute with which Nature decks the earth-her last bright treasures ere she drops her mantle of spotless snow upon its surface.

We find our latest flowering Gentian early in September, and as late as November. If the season be still an open one, it may be seen among the red leaves of the Huckleberry and Dwarf Willows on our dry plains above Rice Lake and farther northward. The Gentians seem to affect the soil on rocky islands and gravelly, open, prairie-like lands, among wild grasses. The finest, most luxuriant plants of G. Andrewsii were gathered on islands in our back lakes, growing in rich mould in rocky crevices. The Five-flowered Gentian may be found on dry banks and open grassy wastes, while again the exquisite azure-blue single-flowered Dwarf Fringed Gentian (Gentiana detonsa-Fries) prefers the moist banks of rivulets and springs. In drier places may be seen the stately many-flowered taller blue Fringed Gentian, G. crinita (Frolich). There is also a charming intermediate form of $G$. crinita, about a foot high, with fewer flowers, but of a richer, fuller azure tint. It is of the Fringed Gentian that the poet Bryant writes:

“ Thou blossom bright with Autumn dew, And colored with heaven's own blue, That openest when the quiet light Succeeds the keen and frosty night. 


\section{STUDIES OF PLANT LIFE}

"Thou comest not when violets lean

O'er wandering brooks and springs unseen;

Thou waitest late, and comest alone

When woods are bare and birds are flown, And frosts and shortening days portend

The aged year is at an end.

" Then doth thy sweet and quiet eye

Look through its fringes to the sky;

Blue, blue as if the sky let fall

A flower from its cerulean wall."

But, bewildered among so many beauties, I have wandered away from my first love, the large dark-blue or open-belled Gentian, Gentiana Saponaria (L.). The leaves of this species are somewhat clasping at the base and pointed at the end, at first green, but assuming a purplish-bronze hue; the smooth stem is also of a reddish purple, with the large open five-cleft dark-blue corollas terminal on the summit, generally three blossoms; between the axils of the leaves three or more somewhat smaller bells may be found at intervals clustered on the flower stem. The beautifullyfolded deep purple buds are surrounded by the pointed bracts and leaves.

This species is less marked than G. Andrewsii (Griseb) by the toothed appendages between the lobes of the flower; the absence of these plaited folds gives our plant a wider, more open flower, which renders it more attractive to the eye of the florist.

There is something almost disappointing in the closed sac-like blossom of the

\section{Closed Gentian-Gentiana Andrewsii (Griseb.).}

Lovely as it is, one would like to peep within the closed lips which so provokingly conceal the interior. The tips of the corolla are white, but the sac-like flower is of a full 


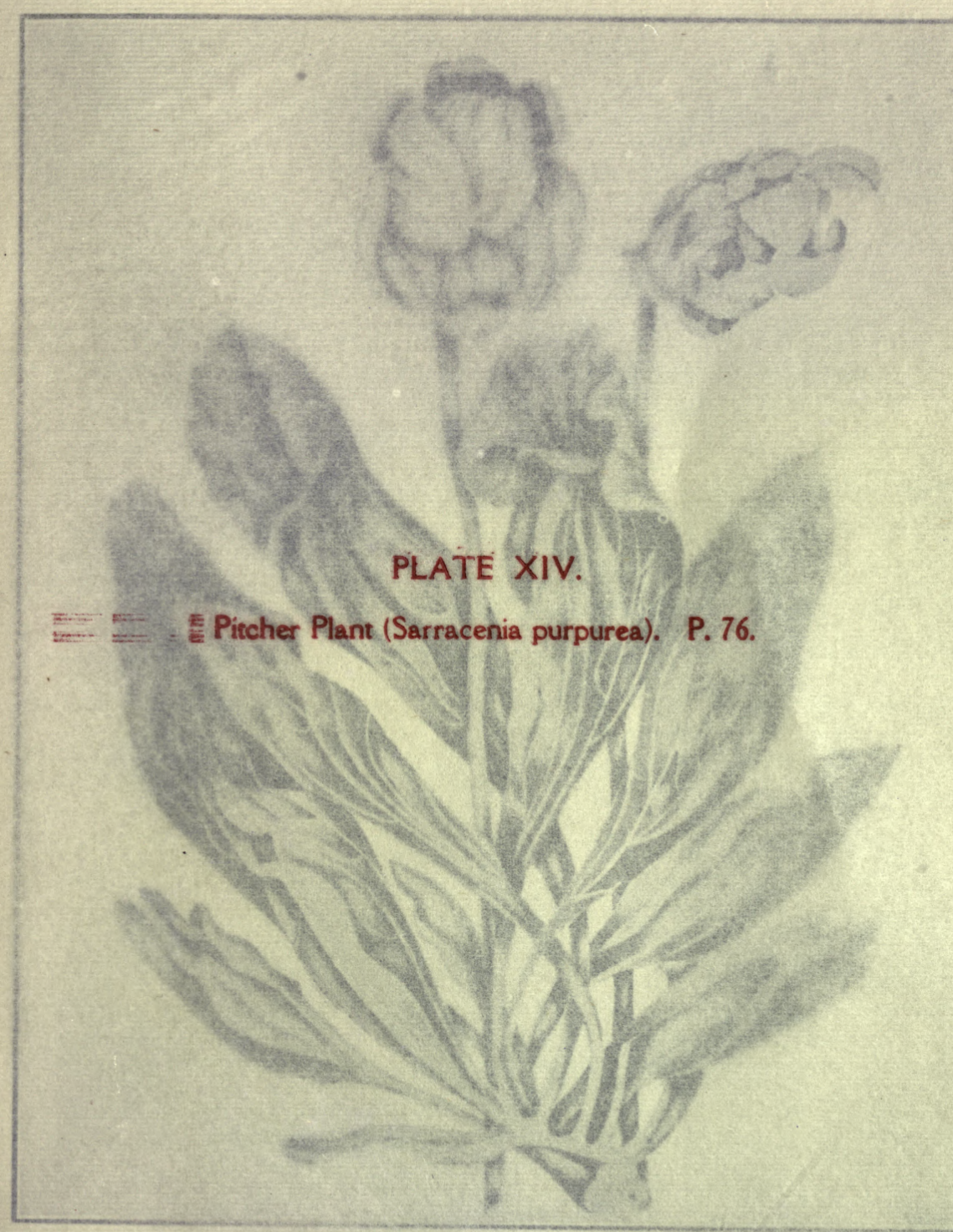




\section{STEDIES OF PLANT IIFE}

"Thou comest not wheir vintets lesis

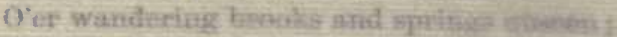

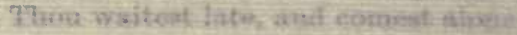

When wonde are bare and bindip axe faths

Ank frosta and shortening days ps iftersest

The aged year is at an end.

"Then doth thy sweet and quiet eye

Look through its fringes to the sky ;

Blue, blue as if the sky let fall

A flower from its cerulean wall."

But, bewildered among so many beauties, I have wanderes away from my first love, the large dark-blue or open-bellec Gentian, Gentiana Saponaria (L.). The leaves of this species are somewhat clasping at the base and pointed at the end, at first green, but assuming a purplish-bronze beses the smooth stem is also of a redalsh yorples, with the linge?

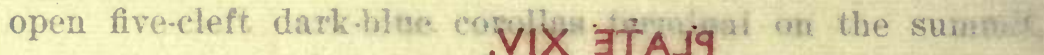
generally thee biensoms; biX JTAJq ils of the leaves

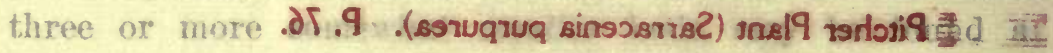
intervals clustered we the thenes meantifully. folded deep purple bable exe sarsumaced by the pointed bivacts and leares.

This species is loss mathend mian a Androusii (Grisel))

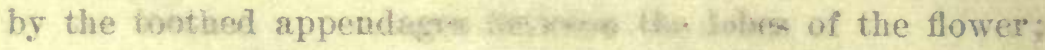
the absence of these plaited foses your ras plant a wider,

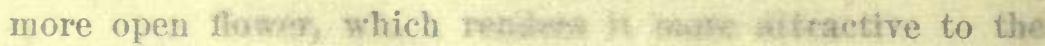
eye of the florist.

There is something almosi disapsoutiotion in the closed sac-like blossom of the

Closed Gextux-Qiestiuma Andrewsii (Griseb.).

Lotely as it is, one woblia like to jeep within the closed lips which so provokingly compal the interior. The tips of the corolla are white, bat the sne-like flower is of a full 
PLATE XIV.

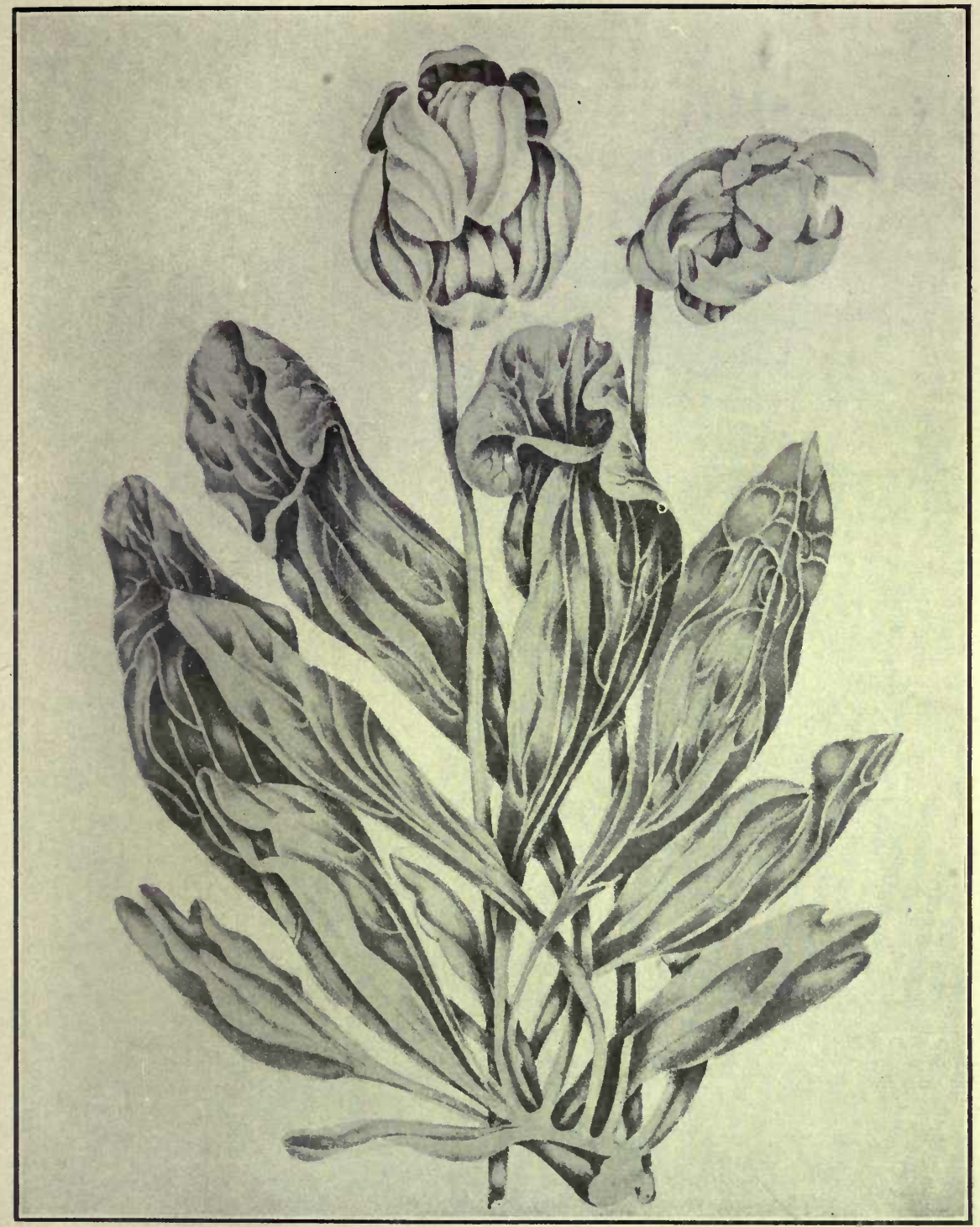





\section{NATIVE WILD FLOWERS}

azure-blue, striped in some cases with a deeper color. There are often as many as five buds and blossoms clustered at the summit of the flower stem and in the axils of the deep green smooth and glossy leaves.

On parting the lips of the closed corolla we see at the narrowed neck some toothed and sharply jagged appendages, which also may be observed in many others of the Gentians in greater or lesser degree. This handsome species is about eighteen inches high, with flowers more than an inch in length, and loves rich leaf-mould near water on rocky islands.

\section{Fringed Gentian-Gentiana crinita (Frol).}

Of the Fringed Gentians we boast three forms, all charming and attractive, and it seems strange that such beautiful flowers should not have found their places long ere this in our gardens. The seeds would not be difficult to obtain from the tallest plant, $G$. crinita, as it blooms early enough to ripen its pods before the heat of the summer has entirely given place to frosts.

I have generally found the tall Fringed Gentian on dry, rather gravelly soil and river banks. The buds of this flower are beautifully folded, almost twisted, and are terminal, growing singly on long foot stalks; the corollas rarely unfold fully; the plaited folds are inconspicuous or absent. The color of the flower of this tall species is light blue, and white at the base; the upper edges of the corollas are elegantly fringed and cut. Though taller, and the bells more abundant, the lower, deeper colored fringed varieties are more lovely.

There is a bitter principle in the roots of most of the Gentians; especially is this strongly developed in the Fiveflowered Gentian-G. quinqueflora (Lam.). This bitter 


\section{STUDIES OF PLANT LIFE}

principle is one of the characteristics of the family, and probably our native plants might prove as valuable tonics as the foreign root were they tested. The Five-flowered Gentian is very unlike the bright and more showy blossomed species described above. The flowers, in fives, are narrow bells of a delicate pale lilac tint, clustered in the axils of the narrow light-green leaves; the plant is found sometimes on dry, grassy banks, and in the angles of fences by the roadside.

I have a specimen closely resembling the above species, sent from Iowa, the chief difference being that the tips of the slender flower-tubes are of a deep dark blue-our Canadian flower being only slightly tinted with very pale lilac. I have never found any of the Gentians growing in the forest, though several species seem to flourish in partial shade in open thickets.

With the Gentians I have brought to a close the floral season of the Canadian year. A few stragglers may yet be found amongst late Asters and Golden-rods, in sheltered glens and lonely hollows, but the glory of the year has departed-gone with the last deep blue bell of the loveliest of her race, the Calathian Violet, the solitary flower of the Indian Summer. All that now remains for us is the bright frosted foliage of the dwarf oaks and the scarlet-tinged leaves of the low huckleberry bushes; the brilliant berries of the leafless Winterberry, Ilex verticillata (Gray), and the clustered garlands of the Climbing Bitter-Sweet, Celastrus scandens, which hang among the branches of the silverbarked birch and other forest trees, or near the margin of lake or stream; and the crimson fruit of the frost-touched High-bush Cranberry, Viburnum Opulus-while on dry, stony hills and rugged rocks the Bearberry covers with its creeping branches of dark green shining leaves and gay 


\section{NATIVE WILD FLOWERS}

scarlet fruit the scanty soil from which it springs. Let us prize them, for from henceforth till the tardy Spring revisits the earth its treasures of leaf and blossom will be to us as a sealed book bound up in ice and snow. No more are we tempted by verdant wreaths of glossy leaves or gaily tinted flowers. We must content ourselves with wintry landscapes, snowflakes and frost-flowers, and the crystal casing that covers the slender branches of the birches and beeches or hangs in diamond drops on the tassels of the spruces and balsam firs.

Tread softly, traveller, lest the transient glory of our frost-flowers dissolve at your feet. Emblems are they of earthly beauty, earthly riches and earthly fame; but there are brighter gems and fairer flowers of heavenly growth that fade not away but which will flourish in the Paradise of God more glorious than the fairest beauties of our earthly home. 


\section{SECTION II.}

\section{FLOWERING SHRUBS OF CENTRAL CANADA.}

" Hie to the haunts right seldom seen, Lovely, lonesome, cool and green.

Hie away, hie away, Over bank, over brae,

Hie away."

-Waverley.

LEATHERWOOD-MOOSEWOOD-Dirca palustris (L.).

THe Leatherwood or Moosewood is one of the very earliest of our native shrubs to blossom; little clusters of yellow funnel-shaped fiowers appear on the naked smoothbarked branches early in April; three or more buds project from an involucre of as many scales covered thickly with soft brown downy hair. The leaves, which expand soon after the falling off of the flowers, are smooth, of a bright light green, oblong, entire, and placed alternately along the stems. This pretty, shrubby bush seldom exceeds five feet in height, but is often much lower. The bark is of a pale greenish-gray, very tough, and while fresh and young not easily broken; it becomes more brittle when thoroughly dried, losing its useful pliant qualities. The bush settlers used the tough bark in its green state as a substitute for cordage in tying sacks and for similar purposes. This hardy shrub is, I believe, the only native representative in Canada 


\section{FLOWERING SHRUBS}

of the Mezereum family;* it has neither the fragrance nor the dark glossy foliage of the Daphne or Spurge Laurel of the English gardens; but, nevertheless, forms a pretty addition to our garden shrubberies, the early blossom, abundant foliage and light scarlet globular berries being very attractive. The New England people call the plant Moosewood, in allusion to the hairy covering of the flower-buds; the Canadians call it Leatherwood, and the Indian name for it is Wycopy, meaning a thong, on account of its tough leathery bark. The specific name, palustris, would imply that it was more particularly a marsh-loving plant; but the Leatherwood may be found frequently growing on dry, gravelly ground, and is by no means confined to wet, marshy soil. Dr. Gray says: "The name of a fountain near Thebes was applied by Linnæus to this North American genus for no imaginable reason, unless because the bush frequently grows near mountain rivulets."

This shrub is found all over the Eastern Provinces of the Dominion and has also a wide northerly range. I know of no especial uses, excepting the one already named, among the settlers in the backwoods and the Indians, who use the bark as loose handles for their bark baskets used in rough work.

\section{Feverbush-Spicebush-Lindera Benzoin (Meisner).}

This highly fragrant shrub is commonly found growing in low, wet, marshy ground, and is sought for by the Indians

* Tbe beautiful Daphne Mezereum, shown on Plate XVI., is not a native of Canada, although it is occasionally found growing wild in the woods near towns. The seeds may possibly have been carried there by birds. Some kinds of finches are said to eat the showy scarlet berries notwithstanding their intense acridity. This shrub was brought to America from Europe, but is thought to be of Eastern origin. The Persians call it Madzaryoum, from which word its specific name is derived. The pretty rose-colored sweet-scented flowers are produced in abundance along the naked branches in early spring, before the smooth green leaves unfold, followed later in the summer by clusters of bright scarlet berries.-J.F. 
for medicinal uses; the bark and twigs (for it is in these the aroma is contained), mingled with tobacco, form one of their luxuries. The spicy, sweet-scented wood long retains its flavor, even when dried, and is most agreeable. The bush is about four or five feet high; the bark of the older branches is gray and smooth, but the young twigs and leafstalks are blackish. The flowers in this, as in Leatherwood, appear in umbel-like clusters in April, before the foliage is developed; the blossoms are yellow or honey-colored, the leaves entire, very smooth, darkish green, oblong and pale underneath. This shrub belongs to the Laurel tribe, and is nearly allied to the Sassafras. The natives make a fever drink of the twigs, besides chewing and smoking the bark.

\section{Trailing Arbutus-Mayflower-Epigora repens (L.).}

(PLATE XVIII.)

The fragrant, graceful Epigcea repens, the sweet Mayflower of the Northern States and of our own Canada, is too lovely to be forgotten in these short floral biographies; indeed, this pretty trailing evergreen is well deserving of a place amongst the most cherished treasures of the conservatory, for few exceed it in beauty and none in fragrance. It is to be found within the pine forests, beneath trees where but a scanty herbage flourishes, and on dry, sandy and rocky ground. we see its evergreen shining ovate leaves and delicate pink flowers covering the ground during the month of May. The Americans know it by the name of Mayflower, so called from its season of blossoming; in England it is a favorite greenhouse shrub, under the name of Trailing Arbutus. The leaves rise on long footstalks from the somewhat horizontal branches, and are unequal in size, the largest being nearest to the summit; the leafstalks are clothed with clammy reddish-colored hairs, which contain 


\section{FLOWERING SHRUBS}

an odorous gum; the flowers are tubular, divided into five segments at the margin, in color varying from white to rosypink; the inside of the long tube is beset with silvery hairs. The lovely waxy flowers are clustered at the summits of the creeping stems, and give out a delightful aromatic scent. The classical name of our pretty evergreen is derived from the Greek, and signifies " upon the earth," in allusion to its prostrate trailing habit.

\section{BeAKed HAZELNut-Corylus rostrata (Ait.).}

The Beaked Hazelnut is a small bush, not more than three to four feet high; the leaves are large, oval, and coarse in texture, furrowed and dentate at the edge. The catkins appear in April; the light crimson tufted pistillate flowers in May. The nut is enveloped in a rough green involucral calyx, which is undivided and closely invests it; this rapidly diminishes in size above the nut, and is prolonged for about an inch; in shape it takes the form of a hawk's bill, whence the specific name rostrata, or beaked, is derived.

The calyx is closely beset with short bristly hairs, which. pierce the fingers, producing an unpleasant irritation; especially is this felt when the fruit is ripe and the enveloping case is withered and dry. The nut is sweet and wellflavored, and resembles the common Filbert more than the wild Hazelnut of England. The bush seems to affect dry open ground and copse woods. - There is another native species, the

\section{AMERICAN HAZELNut-Corylus Americana (Walt.).}

This is a much taller bush, found chiefly in damp thickets, the long slender wand-like nut-brown branches springing from a thickened rootstock or stool, and reaching to a 


\section{STUDIES OF PLANT LIFE}

height of ten to fifteen feet in damp localities. The sweet nut is round and thick shelled, the involucral calyx spreading at the tips and more open than in the former species. The foliage is round, somewhat cordate, or heart-shaped, coarsely pointed and serrated. The flowers, which are of two kinds in this genus, come successively before the unfolding of the leaves. The two species are very distinct in their appearance and character, the Beaked Hazelnut bearing more likeness to the Filbert, while the present species resembles the common Hazelnut.

The classical name, Corylus, is derived from a Greek word signifying a helmet, from the shape of the calyx.

\section{Red-Berried Elder-Sambucus pubens (Michx.).}

The red-fruited Elder is often confounded by ignorant persons with the Rhus T'oxicodendron, to which the names of Poison Elder, Poison Oak, and Poison Ivy have been given, thus transferring the evil qualities of the poisonous Rhus to a perfectly harmless shrubby tree, which deserves to be redeemed from such slanders. The Red-berried Elder is widely distributed over the Dominion of Canada.

In every waste place, on old neglected fallows. which have been subfected to the ravages of fire, in corners of fences, and even in gardens, if care be not taken to ruthlessly root out the intruder, this hardy native may be found. The panicles of greenish-white flowers may be seen in the month of May, among black and burnt stumps and girdled pines, enlivening the coarse verdure of the dull-green pinnated leaves and gray warty branches; the flowers of this species, as well as those of the Black-berried Elder, S. Canadensis (L.), emit a faint but sickly odor. The flowers of the latter species are whiter, borne in much larger and flatter cymes, and do not appear until June. 


\section{FLOWERING SHRUBS}

The embryo blossoms of the Red Elder are formed soon after the fall of the leaf in October, and may be distinctly seen in the large globular buds which adorn the bare branches in winter; they are closely packed within the protecting cases, like hard-green seeds, each flower-bud perfect, as if ready to unfold in the first warm sunshine,-but not so, for the embryo flower must lie dormant in its cradle till the next spring, when the warmth of the May sunshine opens it out to life and light. The blossoms. are succeeded by an abundance of small berries, which, during the month of June, ripen and adorn the landscape with their brilliant scarlet hues. The juice of the ripe fruit is a thin acid, slightly partaking of the peculiar flavor of the wood, not agreeable but perfectly wholesome. The gay berries are a favorite food with wild birds, which soon strip the trees of their ornamental clusters.

Twin-Flowered Honeysuckle-Lonicera ciliata (Muhl.).

Though we have not in Canada the sweet-scented and graceful Woodbine of the bowery English lanes and hedgerows-the theme of many a poet's lay, from Shakespeare and Milton down to Bloomfield and Clare-yet we have some charming flowering shrubs that are too lovely to be disregarded by the lover of Nature. Among our wild native species there is not one more elegant than the Twin-flowered Honeysuckle, or Bush Honeysuckle. It is one of the earliest. of our shrubs to unfold its tender light-green leaves. A few warm days in April-if the season be mild-and we may perceive the slender sprays assuming a welcome tint of verdure, the glad promise of spring.

The ovate leaves, of pale green, are delicately fringed with silken hairs, at first of a slight purplish tint. The flowers. appear in pairs, connected twin-like from the axils of the 


\section{STUDIES OF PLANT LIFE}

leaves; in color something between a pale primrose and greenish-white, often tinged with purple. The elegant drooping bells are divided at the edge of the corolla into five pointed segments, slightly turned outward, showing five stamens and one style, which projects a little beyond the funnel-shaped flower. These graceful flowers, united at the ovary, hang beneath the leaves on slender thready pedicels - so slight that the least breath of air swings their light fairy bells. One might almost be tempted to listen for some sweet music to issue from their hollow tubes. The twin berries, when ripe, are of a semi-transparent ruby-red, but, like the fruit of all the genus, they are tasteless or of a sickly sweet flavor. They form a feast for birds and numerous species of flies, which feed upon the pulp and juice. The country people give the name of "Fly Honeysuckle" to this shrub-doubtless from having noticed how attractive the fruit is to the insect tribes.

The Bush Honeysuckle thrives well in the garden under a moderate degree of shade, and in black vegetable mould.*

The general habit of this shrubby Honeysuckle is upright, not climbing; the branchlets are slender, with a pale grayish-green bark, and bent outwards, which gives a light and graceful aspect to the bush. The juicy crimson berries are oblong, united at the base, and contain several yellowish bony seeds.

\section{SMALL-FLOWEREd HoNeYSUCKLE-Lonicera parviflora} (Lam.).

This pretty clustered trumpet Honeysuckle is also a native of our Canadian woods; a climber, but not often ascending to any great height, sometimes low and bush-like. It might be termed a dwarf climbing Honeysuckle. The flowers are

* It is claimed to be a valuable remedy in cases of dropsy. 
showy and clustered in loose terminal heads; the tube is very slender, and the segments of the corolla are narrowly pointed.

This shrub seems to accommodate itself to circumstances, as it does not attempt to climb when transplanted to open ground, but forms a compact bush.

The abundance of its pale red and yellow flowers, in light graceful clusters and bluish-green foliage, make it a pretty ornament to the garden, to which it takes kindly when transplanted; the only disadvantages are the evanescence of its blossoms and its brief flowering season. The berries, however, are abundant, and are of a pretty light reddish-orange color.

Hairy Yellow-FLowered HoNeysuckle-Lonicera hirsuta (Eaton).

This is a large, robust species; the leaves are large, ovate, and downy underneath, the upper pair perfoliate, forming a boat-shaped involucre to the large hairy honey-colored clusters of flowers, which are terminal. The stem of this rather handsome but coarse species is woody, branching and slightly twining; the hairy yellow trumpet-shaped flowers exude a clammy sweet dew, which attracts numbers of flies which hover about them with those honey-loving vagrants the Humming-birds. This species is chiefly found in open copses and on rocky islands. There are several other native Honeysuckles.

Closely allied to the Loniceras is a pretty flowering shrub known as

\section{False Honeysuckle-Diervilla trifida (Mœnch).}

This shrub is often found on upturned roots in the forest, but it also flourishes in more airy situations, as the edge of open, cleared ground, in the corners of rail fences, where it 
has access to sunlight and freer air. It seldom grows higher than two or three feet, forming a low leafy bush, the leaves oblong, slightly toothed, in opposite pairs; the branches are covered with a smooth red bark; the footstalks of the leaves are also red, the flowers funnel-shaped, the slender corolla divided into five lobes, the lower lip trifid. The flowers, on slender peduncles, mostly in threes, spring from the axils of the leaves. The small seeds are contained in a hard twocelled, two-valved woody pod. The color of the flowers varies from straw-color to tawny yellow. Under cultivation the Diervilla increases in size and abundance of the flowers; it is very hardy and will thrive in sunnier spots than the more delicate Twin-flowered Honeysuckle, which requires shade.

\section{SNOWBERRY-Symphoricarpus racemosus (Michx.).}

Everyone is familiar with that pretty, ornamental garden shrub, the Snowberry, so often seen in English shrubberies, as well as in our Canadian gardens; but every admirer of it does not know that it is a native of the Dominion and may be found growing in uncultivated luxuriance on the banks of streams and inland waters, on the rocky banks of rapid rivers and lonely lakes, whose surface has never been ruffled by the keel of the white man's boat, spots known only to the Indian hunter or the adventurous fur-trapper. There, bending its flexile branches to kiss the surface of the still waters, its pure white waxen berries may be seen, looking as if some cunning hand for very sport had moulded them from virgin wax and hung them among the dark green foliage.

The blossoms of the Snowberry are small red and white bells, in clustered loose heads along the ends of the light, flexible sprays; during the flowering season the branches 


\section{FLOWERING SHRUBS}

are upright, but they droop downward in Autumn from the weight of the large round snow-white berries. The brown bony seeds lie embedded in the granular cellular pulp. Though quite innocuous, the fruit is insipid and more useful for ornament than for any other purpose, as far as man is concerned, but forms a bountiful supply of food to many of the birds that remain with us late in the Autumn. The plant multiplies by suckers from the roots and by seeds. The leaves are small, oval, slightly toothed, of a dull, dark bluish-green. This shrub is a native of all the Northern States of America, extending northward and westward in Canada. It belongs to the same natural order as the Honeysuckle, that lovely creeping plant the Twin-flower, and the Elders.

\section{SWEET-FERN-Comptonia asplenifolia (Ait.).}

The popular name by which this shrub is known among Canadians-Sweet-fern-is improperly applied, and leads to the erroneous impression that the plant is a species of Fern. It is a member of the Sweet-gale family and belongs to the Natural Order Myricacece.

The Sweet-fern grows chiefly on light loam or sandy soil, in open dry uplands, and on wastes by roadsides, forming low thickets of small, weak, straggling bushes, which give out a delicious aromatic scent-somewhat like the flavor of freshly grated nutmegs; but the smell is evanescent, and soon evaporates when the leaves have been gathered for any length of time. The twig-like branches are of a fine reddish color; the leaves are long, very narrow, and deeply indented in alternate rounded notches, resembling some of the Aspleniums in outline, whence the specific name. The flowers are of two kinds: the sterile in cylindrical catkins, with scale-like bracts, and the fertile in bur-like heads. 


\section{SweeT-GaLe-Myrica Gale (L.).}

This sweet-scented low shrub may be found bordering the rocky shores of our inland Northern lakes in great abundance, and may be readily recognized by its bluish dullgreen leaves and the fine scent of the plant. The leaves when stirred or crushed give out a fine aroma resembling that of the Sweet-fern, Comptonia asplenifolia, but of higher flavor. The sterile catkins, closely clustered, appear before the leaves; the seed is contained in rough scaly. heads; the leaves are toothed at the edges, broader at the upper end and narrowing at the base. The whole bush scarcely exceeds four feet in height, but throws out many small branches, forming a close hedge-like thicket near the margins of lakes and ponds, those lonely inland waters, where, undisturbed for ages, it has flourished and sent forth its sweetness on the desert air-" just for itself and God." Yet the qualities of this shrub have not been quite overlooked by the native Indians and by some of the old inhabitants of the back country, who use the leaves in home-made diet drinks and in infusions for purifying the blood.

As the luxuries of civilization creep in among the settlers, they abandon the uses of many of the medicinal herbs that formerly supplied the place of drugs from stores. The old simplers and herbalists are a cult now nearly extinct. I am inclined to agree with a statement $I$ once heard, to the effect that hot stoves and doctors' drugs have fostered or introduced many of the diseases that carry our young people to an early grave and have rendered the old ones prematurely infirm.

\section{New Jersey Tea-Redroot-Ceanothus Americanus (L.).}

There is an historical interest attached to the name of this very attractive shrub which still lingers in the memories of the descendants of the U. E. Loyalists in Canada and in 
the State of New Jersey, where the leaves of the Ceanothus were first adopted as a substitute for the Chinese Tea-plant. Even to this day Americans will cross to Ontario in summer to gather quantities of the leaves to carry back from our plains, where it is found in great abundance. And while they commend the virtues of the plant, they, no doubt, recount the tales of war, trouble and privation endured in the old struggle waged by their grandfathers and greatgrandfathers for independence, when, casting away the more costly tea, they had recourse to a humble native shrub to supply a luxury that was even then felt as a want and a necessity in their homes.

The leaf of the New Jersey Tea resembles that of the Chinese very much, and if it wants the peculiarly fragrant flavor that we prize so highly in the genuine article, yet it is perfectly wholesome, and if prepared by heat in a similar way might approach more nearly to the qualities of the foreign article. Indeed, we are not sure but that it really does form one of the many adulterations that are mixed up with the teas of commerce for which we are content to pay so highly. Many years ago I was applied to by persons in Liverpool to supply their firm with large quantities of the leaves, no doubt for the purpose of adulterating the foreign teas in which they dealt. Of course, the proposal was declined.

An old friend, one of the sons of a U. E. Loyalist, told me that for some years after leaving the United States (the family were from Vermont), the genuine Chinese Tea was rarely to be met with in the houses of the settlers, especially with such as lived in lonely backwoods settlements, that for the most part they made use of infusions of the leaves of the Redroot, or New Jersey Tea, as they had learned to call it, of Labrador Tea (Ledum latifolium), Sweet-fern (Comptonia asplenifolia), Mountain Mint or other aromatic herbs, or 
even of the sprigs of the hemlock spruce. Many of the old folks still retain a liking for the teas made from the wild herbs, and use them as diet-drinks in the spring, of the year with great benefit to their health.

The light feathery clusters of minute white flowers of the Ceanothus have a charming appearance among the dark green foliage, and adorn the hills and valleys of the grassy Canadian plain lands. Where the soil is light loam the shrubs are lower; the flowers also are somewhat smaller, but very abundant, and give out a faint sweet odor. In damper, more shaded spots, the flower clusters are larger and are borne on long footstalks. The leaves of the shrub are ovate, oblong, ribbed, and toothed at the edges. The root is of a deep red color, astringent and used medicinally.

The flavor of the leaves is slightly bitter and aromatic. I consider this pretty Ceanothus to be one of the most orna-, mental of our native flowering shrubs, and well worthy of introduction into our gardens. Abundant clusters of delicate white flowers, that cover the bush during the months of July and August, have the appearance, at a little distance, of the froth of new milk. The flowers are slender, the petals hooded, spreading, on slender claws longer than the calyx, which is five-lobed, colored like the petals. The seed-vessel is three-lobed, splitting into three parts when dry; the seed is round, hard and berry-like. The branches and woody stems wither and die down in autumn, to be replaced by new shoots in the ensuing spring. In height the shrub varies from two to five feet.

\section{Wild Smooth Gooseberry-Ribes oxyacanthoides (L.).}

Our woods and swamps abound with varieties of the widely diffused Gooseberry and Currant family, and though at present neglected and despised, they, no doubt, could, by 


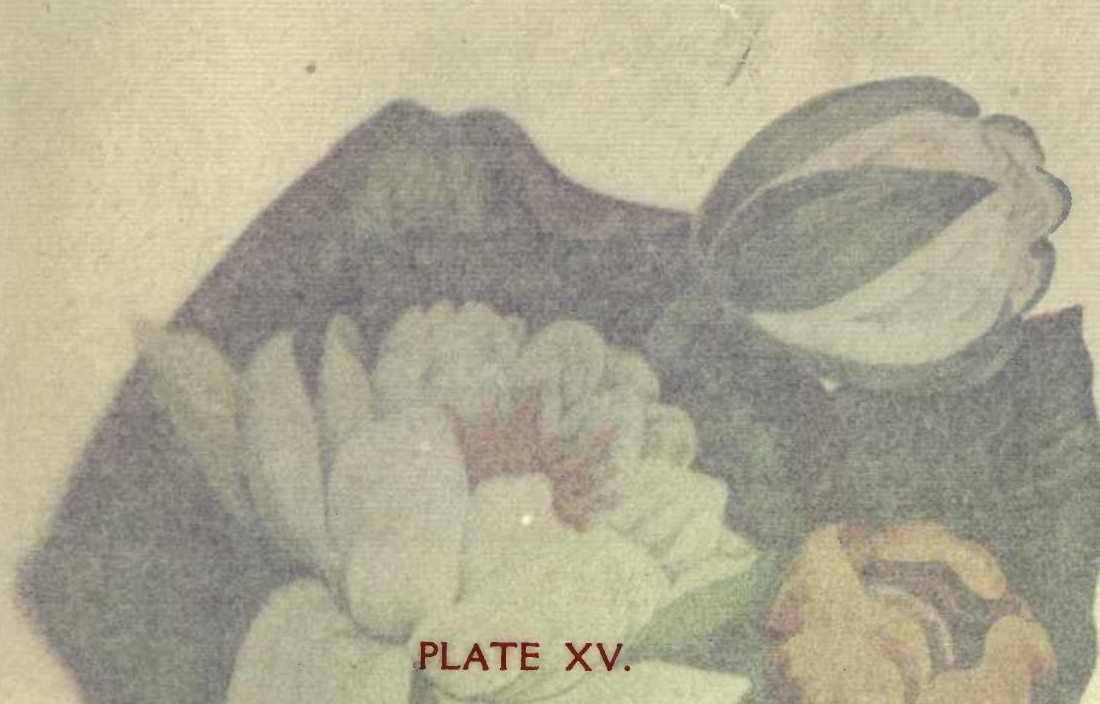

1. Sweet Scented Water-Lily (Nymphrea odorata). P. 86.

2. Yellow Pond Lily (Nuphar advena). P. 90. 


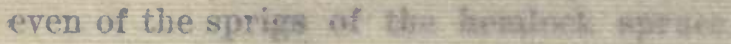

folks still retain a liking for the teas reinte

herbs, and nse them as diet-d rinks in the sate

with great benefit to their health.

The light feathery clusters of minnte wlit

Ceanothus have a charming appearance

green foliage, and adorn the hills and valleys

Camadian plain lands. Where the soil is ligh the

shrubs are lower; the flowers also are somenhit

but very abundant, and give out a faint swees

damper, more shaded spots, the flower clusters an and are borne on long footstalks. The leaves of the are ovate, oblong, ribbed, and toothed at the enterix root is of a deep red color, astringent and used medicinati

The flavor of the leares is $V X \exists T A 1 q^{\text {tter }}$ and aroma I consider this pretey Ccancithas to be one of the most on

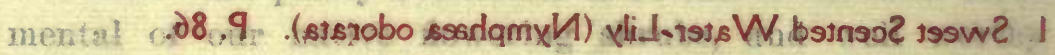

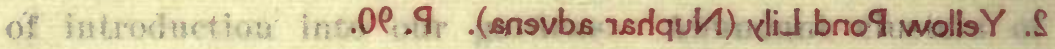

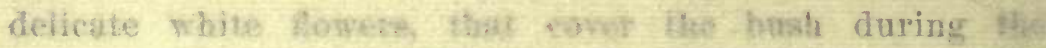

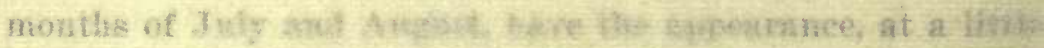

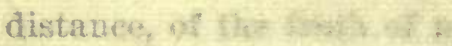

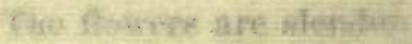

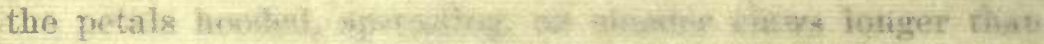

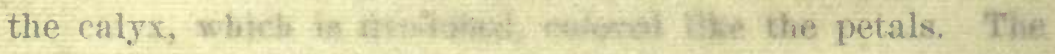

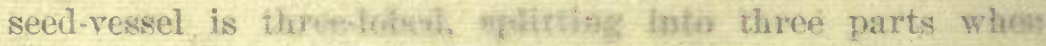

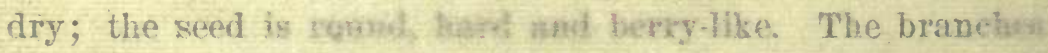
and woody stemas wishoes asial die down in autumn, to 1 .

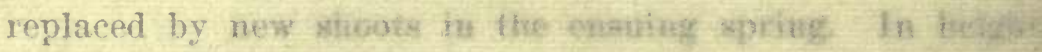
the shrub varies from two to bive bet.

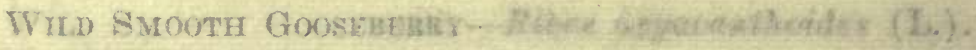

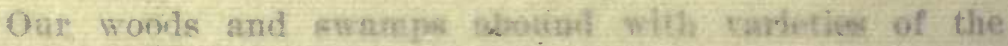

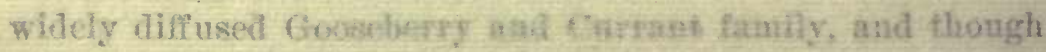
at present neglected and desplead, they, no doubr, could, by 
PLATE XV.

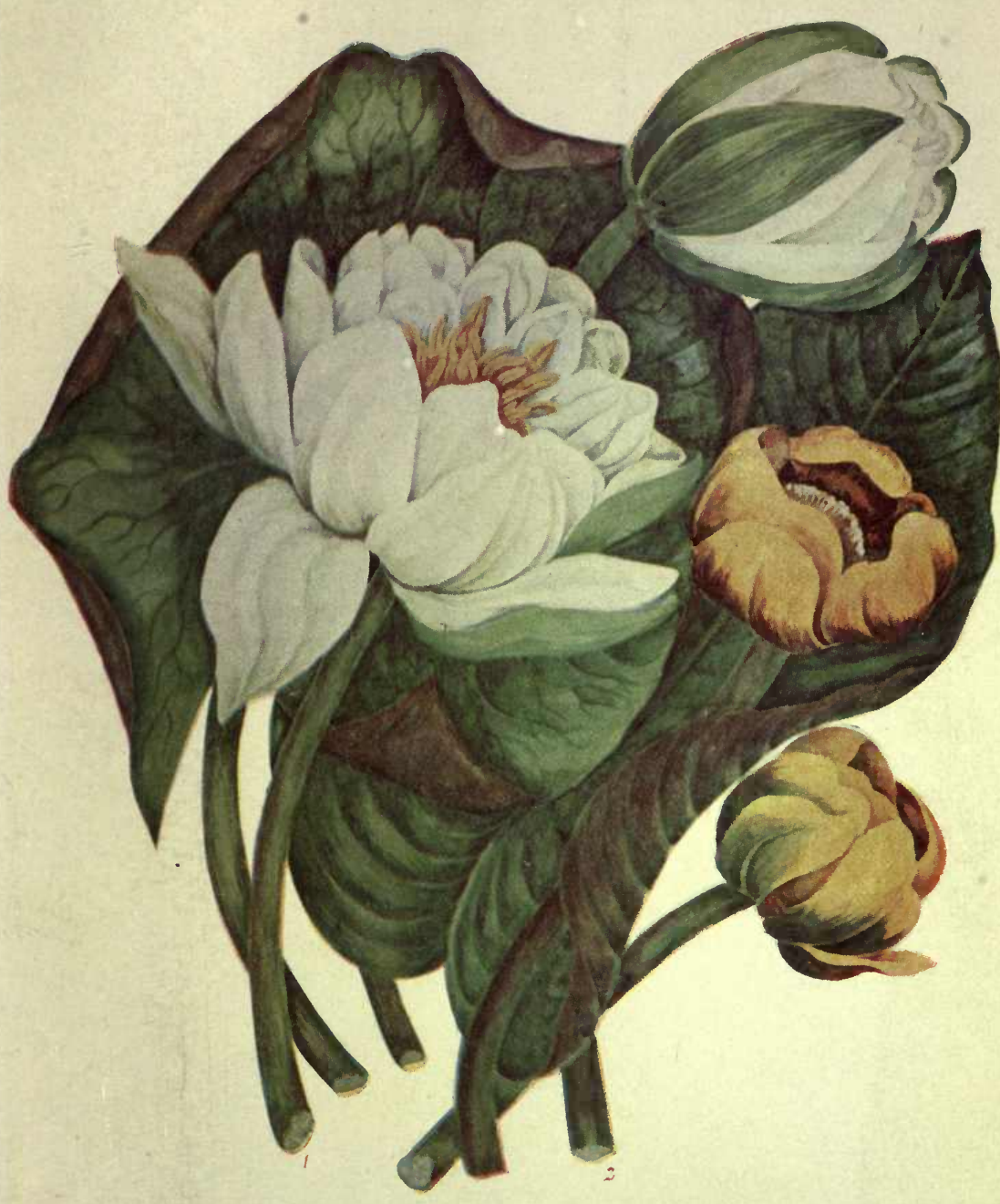





\section{FLOWERING SHRUBS}

proper treatment, be made valuable and serviceable to man. Of the Wild Gooseberry there are several kinds, the best and most palatable being the smooth-skinned, small purple Gooseberry, Ribes oxyacanthoides; this is the least thorny of the genus, and by cultivation can be rendered a nice and serviceable fruit for preserving and other table uses.

This shrub grows in low ground or on the borders of beaver meadows and damp thickets, and seems to be found in every part of the Dominion. The bush is low, not more than from three to four feet in height, or less, with not very prickly stems, and with smooth berries, generally in pairs; the calyx of the flower is purplish and the fruit when ripe is of a dark purple color; the leaves are smooth and shining, and pale beneath.

\section{Thornberry-Prickly Gooseberry-Ribes Cynosbati (L.).}

The fruit of this Wild Gooseberry is perfectly rough and spiny and is troublesome to gather, but in old times it was sought for by the settlers in the backwoods as a welcome addition to their scanty fare. By scalding and rubbing the berries in a coarse cloth much of the roughness was removed; in their green state the berries were used in the form of pies and puddings, or, when softened, mixed with sugar and milk. When ripe they were made into preserves, but the harshness of the bristly skin was not very easily overcome, especially if the fruit was over-ripe. Still it was one of the cheap luxuries that found a welcome place at the shanty table. This is a tall bush from four to six feet in height, growing in dry rocky woods, and bearing a profusion of greenish bells, in the month of May, from one to three on each slender pedicel.

Another of our native Gooseberries, not so wholesome nor so useful, is the 


\section{Small Swamp Gooseberry-Ribes lacustre (Poir.).}

Very pretty in flower, but very bristly, and the fruit small, not larger than peas, in slender racemes, of a purplish color and unpleasant flavor. The blossoms are pink and hang in graceful bunches on the weak and very prickly branches. This small bristly species resembles the

\section{Trailing Hairy Currant-Ribes prostratum (L'Her.).}

This is the least desirable of the Currant family, being far from wholesome. The whole plant is weak and reclining on the ground, often rooting from the joints. The leaves are rather large, smooth and five-to-seven lobed. The small round very pale red berries are hairy, glandular, and of a very unpleasant taste and odor. I have known persons made very ill by eating tarts made of the Hairy Currants. It is easily distinguished by its trailing habit and hairy berries and erect racemes of flowers. I have found it chiefly growing in low lands and thickets, near swamps.

A larger bush, and of common occurrence in swampy ground, is the

\section{Wild Black Currant-R. floridum (L.).}

When in blossom this Wild Black Currant is an ornamental object. The flowers, of a pale greenish-yellow, are larger than the common garden species, and droop in long graceful flowery racemes from the branches. The leaves are of a grayish-green, sharply lobed; the bark gray and smooth; berries very dark red, deepening when ripe to blackishpurple; they are large and somewhat pear-shaped, in flavor not unlike the garden fruit. I should think it possessed of a narcotic quality; certainly it is not very agreeable, though some people like it, and it is extensively used as a preserve. The bush takes kindly to cultivation but is, I think, more ornamental than useful. 


\section{FLOWERING SHRUBS}

\section{Wild Red Currant-Ribes rubrum (L.).}

This is said to be identical with our cultivated Garden Currant. In its wild state the fruit is small, very acid, and not unpalatable or unwholesome, but has a flavor of the astringent bark. This woody taste is common to many of our fruits in their natural state, but seems to be much reduced by care and cultivation.

\section{JUNE-BERRY-SHADBUSH-Amelanchier Canadensis} (T. \& G.).

The June-berries are not very ornamental shrubs, but their fruit is quite pleasant and wholesome, especially when mixed with acid berries, such as currants and cherries. The tallest of the genus is the Shadbush, which is so called from the flowers appearing when the shadflies first rise from the water in the month of May.

The elegant white flowers of this pretty tree (for it rises to the height of twenty feet) adorn the banks of our rivers and lakes and enliven the surrounding woods, breaking the monotony of their verdure by the contrast of the snow-white pendent buds and blossoms. The branches of the Shadbush are somewhat straggling; the leaves of a bluish-green, ovate: and serrated, white underneath; at first they are of a reddish-bronze, but they take a bright tint of green when more mature. The flowers are on slender footstalks, the petals narrow and wavy. The calyx remains persistent, as: in the pear and apple. The fruit is of a dark red, sweet and pleasant. This tree loves gravelly banks and may usually be found near rivers. It is the tallest of the Juneberries; it thrives well under garden culture and is a pretty object when in flower, but not so much so as the next variety, Amelanchier Canadensis, var. oblongifolia, which is a tall, upright, slenderly-branched pyramidal bush, rarely 


\section{STUDIES OF PLANT LIFE}

exceeding twelve or fifteen feet in height; it is very symmetrical in its growth, forming a fine compact pyramid, covered early in the month of May with an abundance of crowded racemes of elegant white flowers, sometimes tinged with pink; the blossoms come somewhat before the tender silken leaf-buds unfold. The foliage is delicately and sharply cut at the margins of the thin ovate oblong leaves, which are soft, silky and folded together. The fruit of this pretty June-berry is small ; when ripe it is of a pink or rose color, sweet and juicy, but somewhat insipid; not so nice as another form which is known in some places by the name of "Sheepberry." This forms a handsome bush about ten feet high, the flower and fruit larger than the former, the berries dark red, almost purple when ripe in July, with a pleasant nutty flavor. Open thickets on the sides of ravines on the Rice Lake plains were favorite localities for the Sheepberry. Another dwarf June-berry, not more than five or six feet high or less, grows in the sandy flats on these same plains. This is a pretty, low shrub with greenish-white racemes of flowers and oval leaves; fruit dark purplish-red and sweet, but the berries are small, not larger than currants; the bark of the branchlets of this little June-berry is dark red, and the leaves are very downy underneath; the fruit is ripe in July and August, about the same time as the Huckleiberries.

\section{DwarF Cherry-Sand Cherry-Prunus pumila (L.).}

The Dwarf Cherry, more commonly known as Sand Cherry, is chiefly found on light sandy lands; it is a low bushy shrub, from eighteen inches to two feet in height; the slender branches are inclined to trail upon the ground, sometimes rooting; the centre stem is more upright. This

*This is a local name; the name "Sheepberry" properly belongs to Viburnum Lentago. 


\section{FLOWERING SHRUBS}

little cherry has a pretty appearance when covered with the clusters of small white almond-scented blossoms, which on short slender footstalks spring, in twos or fours, from the base of the small pale-green leaves that clothe the reddishbarked branches; the fruit, not exceeding the size of a common pea, is purplish-red, without bloom on the surface. The Sand Cherry abounds on light plain-lands; it is the smallest of the wild Cherries and is far more palatable than the fruit of some of the larger trees of the genus. In flavor it partakes more of the nature of the Damson or Plum. Possibly under cultivation the fruit might be greatly improved in size and quality; and the plant is so pretty an object, whether in flower or fruit, that it would repay the trouble of cultivation in the garden as an ornamental dwarf shrub. So eagerly is the fruit sought for by the pigeons and partridges that it is difficult to obtain any quantity even in its most favored localities.

\section{CHOKE-CHERRY-Prunus Virginiana (L.).}

Very tempting to the eye, when fully ripe, is the dark-crimson, semi-transparent fruit of the Choke-cherry, and not unpalatable, but so very astringent that it causes a painful contraction of the throat if many berries are eaten at one time, though some persons are not much affected by them and will take them freely without any ill consequences. The bush is from eight to ten feet high, flowering abundantly and forming a pretty object from the profusion of long graceful pendulous racemes of greenish-white, which have an almond-like scent when fully blown. The leaves also have a pleasant aromatic, bitter flavor like those of the peach and almond, and form a good flavoring, resembling ratafia; when boiled in milk for puddings and custards one or two 
are sufficient, and may be removed when the milk has boiled. This flavoring is harmless and pleasant and easily obtained.

The Choke-cherry never reaches to the dignity of a tree, like the Wild Black and Wild Red Cherry of the woods, but forms a pretty flowery shrub of straggling growth. It blossoms in June and ripens the fruit in August. In respect of both flower and fruit it is very ornamental, and may be introduced with advantage to the shrubbery-but so tempting are the ripe berries to the smaller fruit-loving birds that it is soon stripped of its rich crimson load of pendent fruit. The cedar or cherry-birds are sure to find out the bush and visit it in flocks till they strip it entirely, leaving the ground below strewed with the berries that have been shaken off; possibly the ground-squirrels and field-mice thus come in for a share of the spoils.

\section{Prickly Ash-Xanthoxylum Americanum (Mill.).}

This is a handsome shrub with glossy pinnate leaves, the valuable qualities of which are hardly sufficiently known and appreciated by those who know it only for its ornamental appearance, when the crimson cases that envelop the black shining seeds appear in clusters between the bright green leaves. The leaflets are in five pairs, with one terminal, from an inch to two inches in length, serrated at the edges, pointed, of a lively bright green, very glossy on the surface; the stem and branches straight, covered with whitish-gray bark; the branches set with stout woody prickles, which also extend along the mid-rib on the underside of the leaves. The flowers are yellowish-green, in close set clusters, appearing before the leaves. The fruit is a round hard shining bead-like berry, on a little thready stalk, two in each pod, at first a bronzed green, deepening to deep crimson when ripe, 
opening and shewing the dark glossy seeds. The whole plant is highly aromatic, especially the cases that enclose the seeds, which, when rubbed between the fingers, emit a strong pungent odor like the scent of orange-peel.

The root, bark, leaves, and fruit are bitter, pungent and aromatic. The root and bark are used in dyeing yellow; they are also used medicinally in extract for agues and intermittent fevers.

Though its most usual locality is on the banks of streams and in low wettish ground, it will also thrive and increase rapidly on dry soil, and on account of its stout woody stem it seems well suited for hedges. The Prickly Ash will grow both from seed and by shoots sent up from the roots. The fruit is ripe in August and September. The dry seed-pods are in great request by smokers, who mix them with tobacco and regard the fine spicy scent as a great luxury when they can obtain the berries from the Indians.

The following valuable remarks on the medicinal uses of this interesting shrub were copied for me by my late, much valued friend, Dr. Low, of Bowmanville, from an article in the Journal of Materia Medica, No. XII., December, 1859, by Dr. Charles Lee, on the Medicinal Plants of North America:

"The 'Prickly Ash' is known also by the name of 'Yellowwood.' The bark contains a fixed volatile oil, resinous coloring matter, gum and a crystallizable substance. The berries contain a large amount of oil, one pound yielding four fluid ounces when treated with alcoholic ether. The Prickly Ash is employed as a remedy for affections of the spine, marrow' and vascular system. The active properties consist of an ethereal oil, like oil of turpentine; it is decidedly stimulant in languid cases of the nervous system.

"In Asiatic cholera, during the years 1848-50, it was used 


\section{STUDIES OF PLANT LIFE}

with great success by American physicians in Cincinnati: it acted like electricity, so sudden and diffusive was the effect on the system.

"In the summer complaint of young children it is also used with great success. The following is an excellent receipt for that disease among children:

"Rhubarb-root, Colombo cinnamon-of each 1 drachm; Prickly Ash berries, 3 drachms; good brandy, half a pint. Add the bruised articles to the brandy, shaking them occasionally for three or four days. The dose for a child of two years old is a teaspoonful thrice a day in sweetened water. Where any swelling of the body is apparent, equal parts of the tincture of Prickly Ash berries and olive oil is of great use rubbed in over the abdomen. In typhus and typhoid fevers the value of this tincture is very great. A teaspoonful diluted with water may be given, in cases of great depression and prostration, every twenty minutes; it is also used most successfully in chronic rheumatism."

I make no apology for introducing the above, thinking it may prove a valuable receipt.

Another of our lovely creeping forest evergreens is the

Creeping Snowberry-Chiogenes hispidula (T. \& G.).

This interesting little plant forms beds in the spongy soil of the damp cedar swamps, spreading its matted trailing branchlets over the mossy trunks of fallen trees. The foliage is dark green, very small, and myrtle-like in texture, hard and glossy. The flowers, which are solitary in the axils of the leaves, are not very showy; they are bell-shaped and four-cleft at the margin, greenish-white in color. The berry is pure white and waxy, and lying in the deep green mat of tiny evergreen leaves has a charming effect. 
Chiogenes hispidula belongs to the Heath family and grows in cool peat bogs and mossy mountain woods, in the shade of evergreens; the whole plant has the aromatic flavor of the Teaberry or Aromatic Wintergreen, Gaultheria procumbens.

\section{HUCKLEBERRIES-BLUEBERRIES.}

Several varieties of this useful and agreeable fruit are spread all over the country, even to the farthest northern and eastern portions of the now widely extended Dominion. Many of the species are hardy and will bear the severity of almost Polar cold, and will flourish in the poorest soil. The commonest to be met with are the large Blueberries, Vaccinium Pennsylvanicum, V. Canadense and V. corymbosum, which abound in the oak-openings, in swamps, and on the stony islands of our back lakes.

\section{Dwarf Blueberry-Vaccinium Pennsylvanicum (Lam.),}

is the earliest to ripen its large sweet berries. The flowers, which are delicate waxy bells, appear early in May and with the young leaves are pinkish in color. The leaves are lanceolate, with serrated margins, smooth and shining on both sidès. The berry is ripe early in July, and is the earliest Blueberry brought to the market.

This is a low bush, one to two feet high, found growing in woods and on the borders of swamps.

\section{Canada Blueberry-Vaccinium Canadense (Kalm.),}

is a low shrub with downy branches and leaves, very similar to the above but generally smaller and with shorter greenish flowers, striped with red; the leaves are not serrated at the margin, and the fruit is not quite so early. It generally grows in damper situations. 
This is a large handsome shrub, from five to eight feet high, found in many varieties growing in swamps. The corolla is larger than either of the above and of a purer white. The leaves are ovate and entire, and slightly pubescent. The rich berries begin to ripen in August, and are the latest of the season.

These pretty shrubs, laden with their luscious berries, may be found on all dry open places. The poor Indian squaw fills her bark baskets with the fruit and brings them to the villages to trade for flour, tea, and calico, while social parties of the settlers used to go forth annually to gather the fruit for preserving, or for the pleasure of spending a long summer's day among the romantic hills and valleys, roaming in unrestrained freedom among the wild flowers scattered in such rich profusion over those open tracts of land where these useful berries grow. These rural parties would sometimes muster to the extent of fifty or even an hundred individuals, furnished with provisions and all the appliances for an extended picnic.

Many years ago, when the beautiful Rice Lake plains lay an uncultivated wilderness of wild fruits and flowers, shaded by noble, wide-spreading oaks, silver birches and feathery pines, an event occurred that excited great interest in the neighborhood and for miles around, the excitement even penetrating to distant settlements on the Otonabee, then the border-land of civilization north of the Great Lakes.

It was in the month of July, 1837, that a large party of friends and neighbors near Port Hope agreed to make a picnic party to gather huckleberries and pass a pleasant summer day on the Rice Lake plains. They made a large gathering in waggons and buggies and on horseback. Among 


\section{FLOWERING SHRUBS}

the children belonging to the party was a little girl about seven years of age, a bright, engaging child. By some accident this little one got separated from her family among the bushes, and they, supposing that she had gone forward with some of their near neighbors and friends, started for home, feeling no uneasiness until it was discovered that little Jane was not among the returned party, and that no trace of her could be found. Then came the stunning conviction that the child was lost-left alone to wander over that pathless wilderness in darkness and solitude, perhaps to fall an unresisting prey to the bear or the wolf, both of which animals at that distant period roamed the hills and ravines of those plains in numbers, unchecked by the rifle of the sportsman or the gun of the Indian hunter.

A few cleared spots there were, but these were miles apart, and it was not likely that the timid child would find her way to any of the distant shanties, so that no reasonable hope of the child finding shelter for the night could be entertained. Under so sad a loss the distress of the bereaved parents may easily be imagined. Their agonizing suspense, their hopes and their fears, found a ready response in every kind and feeling heart.

No sooner was it known that a young child was lost than hundreds of persons interested themselves in the discovery and restoration of little Jane Ayre. The people came from their farms; they poured out from towns and villages, from the borders of the forest; wherever the tale was told came men in waggons, on horseback and on foot, to scour the plains in every direction. The Indians, under their Chief, Pondash, came under promise of a liberal reward if they found the child. Day after day passed without tidings of the lost one. As night came on each party returned only to 
say the child was not found, and hope began to fade away in all hearts. It still lingered, however, in that of the father.

It was now Thursday, and it was on the evening of the previous Saturday that the little girl had been lost. The chances were indeed remote that she would be found, or if found that she would be a living, breathing child. However, about noon that day a horseman was seen riding at full speed towards the farm, followed by a crowd that thronged the road. The lost child was found! Alive or dead? There was a stop, a pause in the pulsation of the woe-worn heart of the mother. Could it be that after five days of famine and wandering, exposed to the rain and dews and the sun's hot rays, that she should behold her child alive once more? Yes, it was even so, and He who tempers the rough wind to the shorn lamb and shelters the unfledged nestling of the the wild birds had been her guard by night from the wild beasts and her shield by day from the elements. No harm had befallen the young wanderer save what naturally arose from exhaustion and fear in her unusual position.

Each night she had lain down and, sheltered by a fallen pine tree, had slept as soundly as if on her own little bed at home. The first night a drenching thunder-shower had soaked her clothes, and she had lost her shoes in the grass and had not cared to seek for them. Her face was much sunburnt, and she said each day she had heard voices in the distance, but her fear of strangers, and especially of Indians, had made her conceal herself. One thing was remarkablehope and trust in her father had never deserted her young heart. She said she knew that he would never cease to look for her till she was found. It was with the hope of seeing that dear face that she came from her hiding-place and stood upon the $\log$ and looked about her and was fortunately discovered by one of the searchers, whom she knew by sight; 


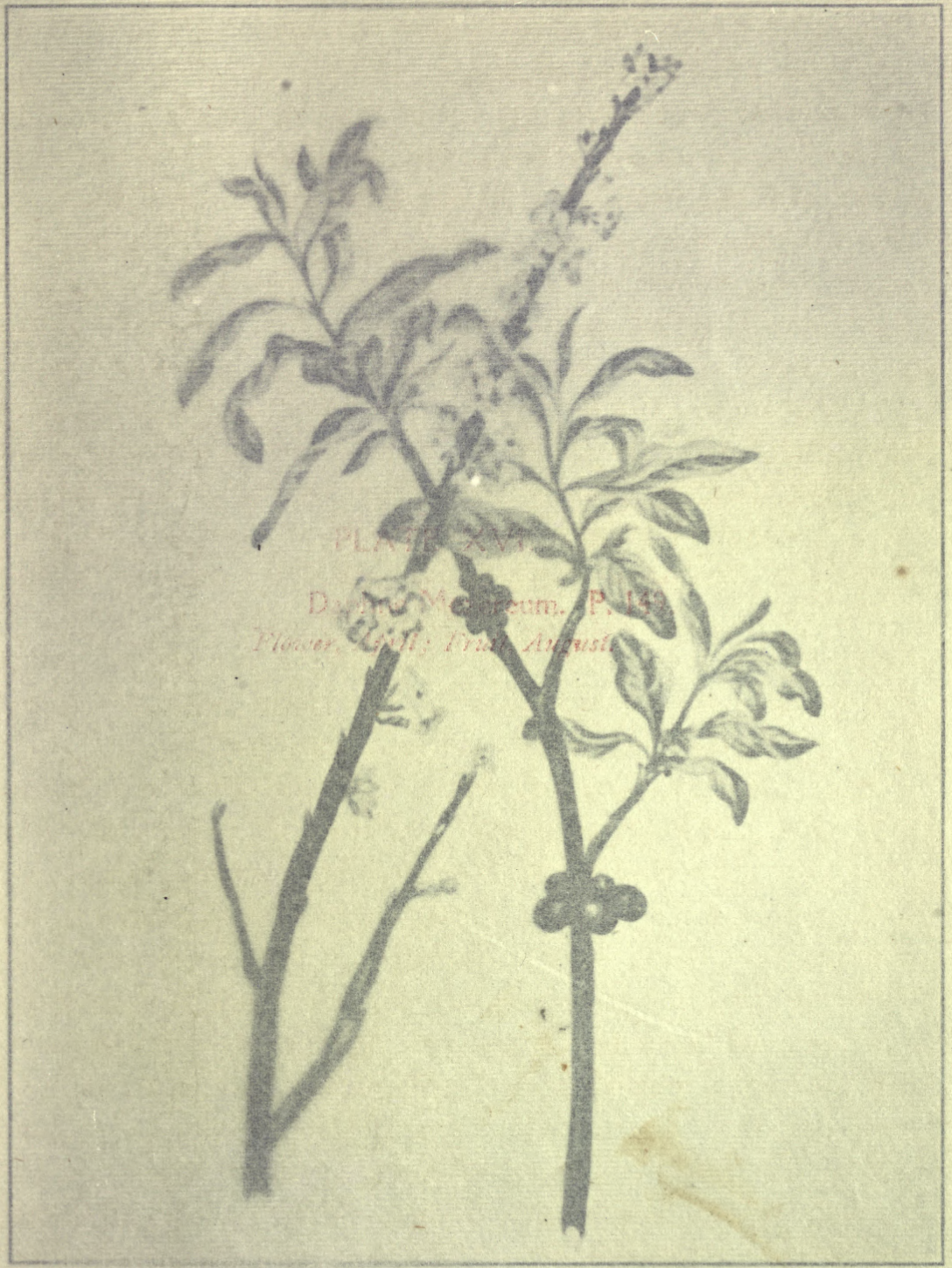




\section{STUDHES OF PHAXT HIFE}

say the child was not fonnd, and bope began to faith away in all hearts. It still lingerwd, bowerer, in biat of tipe cather.

It was now Thursday, and it wals on tliet previous Saturday that the little giri hat chances were indeed reinote that she womin found that she would be a living, breathing . about noon that day a horseman was seen speed towards the farm, followed by a crowd that the road. The lost child was found! Alive or detat was a stop, a pause in the pulsation of the woempris of the mother. Could it be that after five days of the and wandering, exposed to the rain and dews and the $x$ hot rays, that she should behold her child alive once anYes, it was even so, and He who tempers the rough winat the shorn lamb and shelters the unfledged nestling of the wild birdas had thed hel ghand by night from the silut beasts and her shield by thy divin the elewenta. Ne beres had befallen the yousig wasetores sare what naturally erces from exhanstion and fear in her nuusual position.

Each night she had lain down and, sheltered by a fulles pine tree, bad slept as souml!y as if on her ewn litthe bist

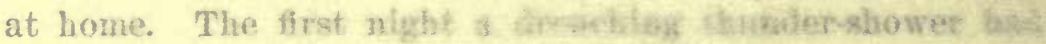

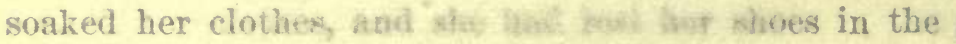
and had not cares to soeh tent thom. Her face was

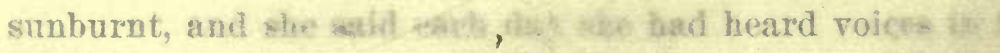

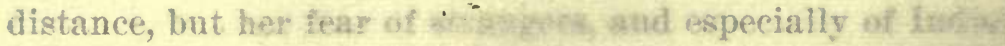
had made her conceal hemsibs. ome thing was reanarkchis

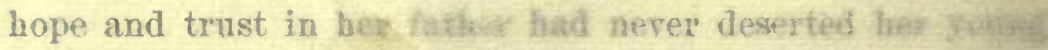
heart. She said she knew that he would never eana kip twot for her till she was found. It was with the hoge of edeing that dear face that she came from her hiding-place and stood upon the log and looked about her and was fortzaately discorered by one of the searchers, whom sde harw by sight; 


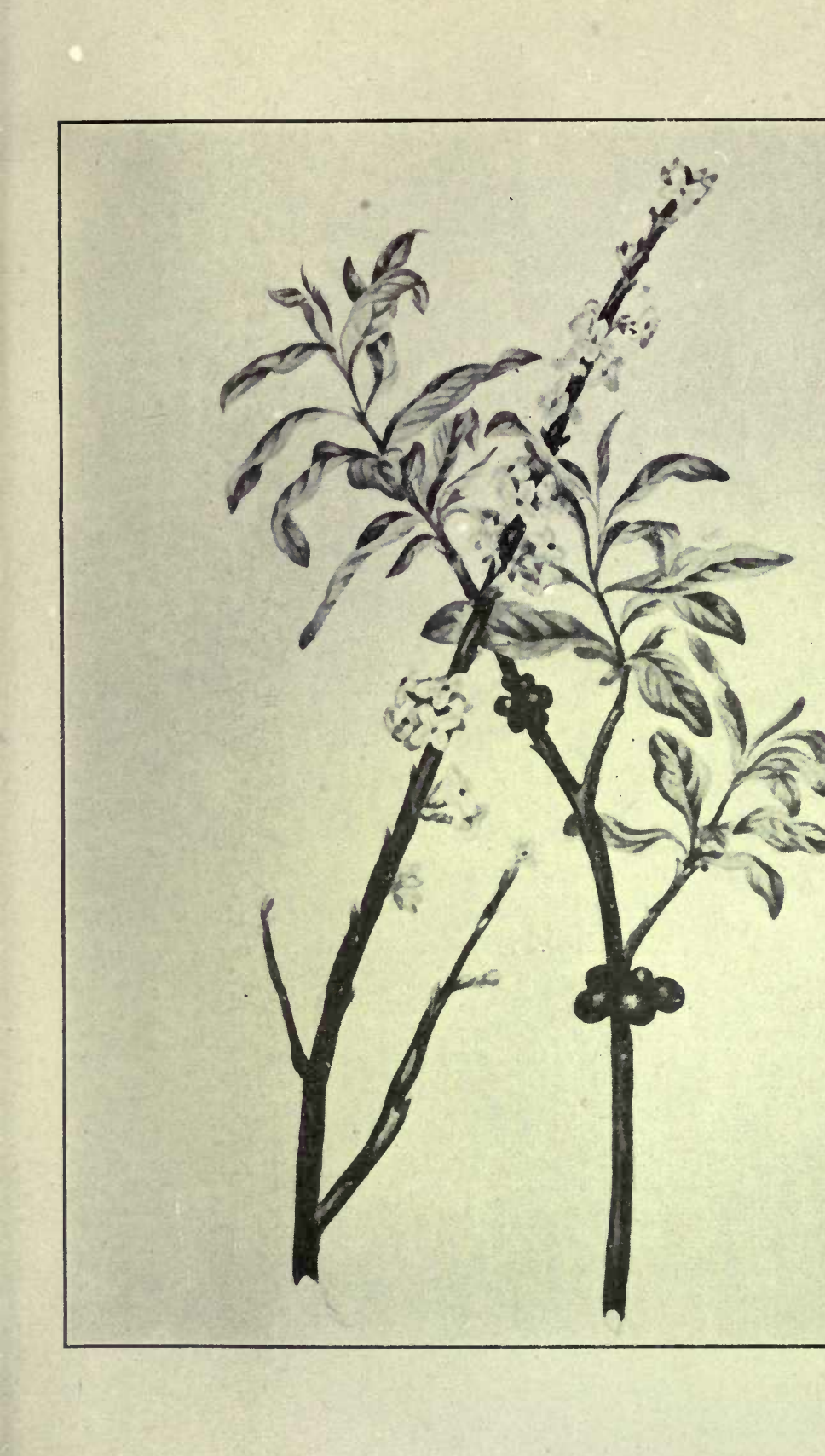



and then what a cry of joy arose, such as those wild plains had never echoed before, "The child! The child!" It reached the father's ears, though distant far from the spot, and he scarcely believed, for joy, till she was placed warm and breathing in his arms. The crowd instinctively drew back for a space and left the father and child clasped in each other's arms. Many a manly cheek was wet that day when they saw the childish face, thin and wan as it was, nestling in the father's arms, her thin browned hands clasped about his neck as if no power on earth should part them again.

Surely the father might have cried out in the fulness of his heart, "Rejoice with me, my friends, for this my lamb was lost and is found!"

Years have passed away, and little Jane has long been a wife and happy mother, and, no doubt, has often told her children the tale of her adventure on the Rice Lake plains, and pointed them to the gracious Father in Heaven who kept her under the shadow of His wing during those days of danger and fear.

The plains are now cultivated in every direction; the huckleberries are fast disappearing and will have to be sought for elsewhere.

\section{Frost Grape-Vitis cordifolia (Mx.).*}

Those deep, embowering masses of foliage; those verdant draperies that fall in such graceful leafy curtains from branch to branch, roofing the dark, shady recesses of our wooded lakes and river banks; those light feathery-clustered blossoms that hover like a misty cloud above the leafy mass, giving out a tender perfume as the breeze passes over them, like sweet Mignonette,- those are our native vines, our Wild Grapes.

${ }^{*}$ V. riparia (Michx.) of Gray's Manual, sixth edition. 


\section{STUDIES OF PLANT LIFE}

Yon tall dead tree that stands above the river's brink is wreathed with a dense mantle of foliage not its own. The changing hues of the leaves, the deep purplish clusters of fruit, now partially seen, now hidden from the view, have given a life and beauty to that dead, unsightly tree.

The ambitious parasite has climbed unchecked to the very topmost branch, and now flings down its luxuriant arms, vainly endeavoring to clasp some distant bough; but no, the distance is beyond its reach, and it must once more bend earthward or, in lieu of better support, entwine its flexible tendrils in a tangled network of twisted sprays, leafstalks, and embowering leaves and fruit.

The fruit of the Frost Grape-our northern grape-vineis small. The berries, round, blue or black, with little or no bloom, very acid, but edible when touched by the frost, and can be manufactured into a fine jelly and good wine of a deep color and high flavor. Whole islands in the Trent and Rice Lake are covered with a growth of this native Grape. There is not a lake in Canada but has its "Grape Island," and many persons cultivate the plants about their dwellings over light trellis work, under which circumstances they will yield an abundance of fruit. They are also very useful to conceal unsightly objects, such as outhouses. An old pine stump can be converted into an ornamental object by nailing cedar poles-fastened at the top-round it, and planting grape-vines about it, having first prepared a bed of good earth and large stones to bank the lower part; a few plants of the Wild Clematis intermixed with the Grapevine, and a sprinkling of Morning Glories, make a lovely pyramid and convert a defect into a charming object during many months of the year.

The Wild Grape seems to flourish best in its natural state near the water, but will grow and flourish well in gardens 


\section{FLOWERING SHRUBS}

where it is given the support of a trellis, or in any suitable position where it can climb. I have even seen a dead tree specially planted for such a purpose.

\section{Fox GraPe-Vitis Labrusca (L.).}

This is the original of the cultivated Isabella Grape, which has long been introduced into our gardens and vineries as worthy of the attention of fruit growers.

The leaves of this species are very densely woolly, covered, especially when young, with tawny, silky hairs; the fruit is of a dark purple, of a musky flavor, whence its common name, Fox Grape.

This Wild Grape is found on the shores of Lake Erie and to the westward. From the improvement made by cultivation in the size and quality of the Wild Fox Grape we may perceive how much might possibly be done with others of our wild fruits, which when introduced into our gardens. would have the advantage of hardiness beyond that of exotics in bearing the severity of our climate. It seems reasonable to suppose that plants that are indigenous to a country could, by due care, be brought to a state of higher perfection than when under a foreign sun and soil, and that the culture of wild plants would amply repay the cultivator. Attempts of this kind are rarely made or persevered in, so that the result is not often satisfactory; either the process is thought to be too slow, or we despise as common that. which is within our reach, valuing that which is more costly above what is easily obtained, whilst we eagerly spend our money to obtain a foreign species, which may possibly have been originally taken from our native woods and wilds to a foreign country, there cherished and cared for, improved by cultivation, and returned to us increased in value. It would greatly enhance the pleasure of cultivation if we were our- 
selves able to show native flowers and shrubs and fruits rendered equal to the imported kinds by our own culture.

We might compare these wild plants to the neglected children of our poorest classes. In the degradation arising from their uncared for state they become as moral weeds in the great garden of life, neglected and passed by, left to run wild, and shunned. But remove these children to a more genial atmosphere; let them be taught the value of their souls, for which so great a price was paid by their Redeemer; let them be clothed and fed and cared for, made to feel that they are not despised in the eyes of their fellow men; then their useful qualities brought into action, and their vices and evil passions controlled, like the wild plants they will rise in value, and beauty, and usefulness, becoming precious trees bearing fruit to the glory of Almighty (rorl-sought out and desired of all men. Who will cultivate and improve this garden of human growth? Must it continue a wilderness, rank and injurious, full of deadly poisons and unripe, crude and bitter fruits, while within it, choked and hidden from view, are the germs of usefulness, beauty, and happiness that only require the better soil, the fostering care and gladdening sunshine of Christian love and kindness to make them what their Creator would have them all to be? Truly "the harvest is great, but the husbandmen are few."

Allusions to the grape-vine and vineyards are of frequent occurrence in Scripture. Many and beautiful are the passames where the ancient Church is symbolized by the poetical figure of the vine and the vineyard. How touching is the appeal made by the prophet to the rebellious and idolatrous people in the fifth chapter of the book of Isaiah: "And now, O inhabitants of Jerusalem, and men of Judah, judge, I pray you, betwixt me and my vineyard. What could have been done more to my vineyard, that I have not 


\section{FLOWERING SHRUBS}

done in it? Wherefore, when I looked that it should bring forth grapes, brought it forth wild grapes?"

Beautiful are the allusions made in the Song of Solomon in his invitation to the beloved to go forth to the garden he had planted. "The fig tree putteth forth her green figs, and the vines with the tender grape give a good smell. Arise, my love, my fair one, and come away."

"Let us get up early to the vineyards; let us see if the vines flourish, whether the tender grapes appear."

Probably the culture of the vine was among the earliest labors of the husbandman, and must have been of most ancient usage, the first work enjoined by the Almighty Creator when he placed man in the Garden of Eden-which was most likely a large and fertile tract of country already enriched with every tree and herb and flower that would prove useful for the support of life and contribute to man's enjoyment. Adam was instructed by his Maker to till the ground and dress it and keep it.

This employment was ordained for health and pleasure, not for toil or weariness. This last condition arose when sin had marred the fair beauty of God's world and the sinsmitten earth no longer yielded its spontaneous fertility as in the day when sinless man first stood in his innocence on the then unpolluted earth, a fearless being in the presence of a holy God.

The vine, which might have formed a delightful portion of man's food in the Edenic garden, must from henceforth yield its luscious grapes only by care and labor. The wild vines must be pruned and trained and kept free from noxious weeds and hurtful insects; they were no longer the fruit of the Lord's vineyard. Who can tell but that our wild Canadian Frost and Fox Grapes may not be the degenerated 
seed of the wild vines of that land of the east into which Adam and Eve were banished?

Travellers in Palestine still speak of the luxuriant grapevines flinging their clusters of fruit and sweet-scented blossoms over the terraced steps of rocky ravines, filling the air with perfume; but the vines are all wild now and uncultivated. They want the careful hand of the vinedresser and husbandman to train them-type of the wasted inheritance of the ancient people and of a degenerated priesthood.

Has the Christian Church no careless vine-dressers; are there no vines bringing forth wild grapes; no briars and thorns that come up to choke the Lord's vineyard, till it becomes an unfruitful wilderness?

BlaCK HaWTHORN-PeAR THORN-Cratogus tomentosa (L.).

Canada has many species of Hawthorn, but not the fragrant flowering May of the English hedgerows, associated in the minds of old Country people with the pleasant spring days and bowery lanes of their childhood, when, as old Herrick tells us, "Maids went maying." But eren now in Merrie England the May-queen's reign is over, in spite of poets' songs.

LAMENT For THE MAY-QUEen.

No maiden now with glowing brow

Shall rise with early dawn,

And bind her hair with chaplets rare

Torn from the blossomed thorn.

No lark shall spring on dewy wing

Thy matin hymn to pour,

No cuckoo's voice shall shout 'Rejoice!'

For thou art Queen no more. 


\section{FLOWERING SHRUBS}

Beneath thy flower-encircled wand

No peasant trains advance;

No more they lead with sportive tread

The merry, merry dance.

The Violet blooms with modest grace

Beneath her crest of leaves,

The Primrose shows her paly face,

Her wreaths the Woodbine weaves.

The Cowslip bends her golden head, And Daisies deck the lea;

But ah, no more in grove or bower

The Queen of May we'll see.

Weep, weep, then, virgin Queen of May,

Thy ancient reign is o'er;

Thy votaries now are lowly laid, And thou art Queen no more."

The Pear Thorn is one of the finest of our native species, often rising to the height of from fifteen to twenty feet, with a stout rough-barked stem. When in flower it forms a fine ornament to our open woods and thickets, for it is not found in the depths of the forest; it haunts the open edges of woods, and more especially is found along the banks of rivers and creeks. The flowers are much larger, though less delicate in scent, than the English Hawthorn. The leaves are thick and tough, but smooth and shining, unequally toothed, ovate-oblong; thorns, long, sharp and slender. The white cup-shaped flowers with dark anthers grow in handsome corymbs, many-flowered on the summits of the sprays. The fruit is large, round and of a bright scarlet or orange.

\section{SCARLET-FRUITED THORN-Cratogus coccinea (L.).}

is no less ornamental than the former, and also forms a fine high flowering bush; the fruit is of a pleasant acid taste and of a fine bright scarlet; the leaves are thin, partly lobed and sharply cut at the rounded margin. This thorn grows tall 
and slender in close thickets and shade, but seems to prefer open ground and plenty of sunshine, when it forms a lovely compact tree and flowers abundantly; the fruit is not so large as in the last species, and is of a deeper red color.

The English White Thorn (Cratcogus oxyacantha-L.) in some situations grows beautifully, but is apt to dwindle and become mossy and gnarled in unsuitable places where it is neglected.

I saw a most perfect specimen of the English White Thorn at Port Hope, on the lawn at the residence of C. Kirkhoffer, Esq., at the western side of the town; it was in full flower at the time, and formed one of the most beautiful objects I ever saw; it was worth going miles to look upon it and to inhale the sweetness of its abundant white blossoms.

There appears to have been little attempt made to cultivate our hawthorns as hedge plants, though one might naturally suppose that such would have been adopted in places where the difficulty and expense of obtaining rail timbers is now being sensibly felt by the farmer. The cedar and hemlock are largely used for garden enclosures. Why not try the hawthorn also?

\section{Small Cranberry-Vaccinium Oxycoccus (L.). \\ " There's not a flower but shews some touch, In freckle, freck or stain, Of His unrivalled pencil."}

-Hemans.

There is scarcely to be found a lovelier little plant than the common Marsh Cranberry. It is of a trailing habit, creeping along the ground, rooting at every joint, and sending up little leafy upright stems, from which spring long slender thready pedicels, each terminated by a delicate peach-blossom-tinted flower, nodding on the stalk so as to throw the narrow petals upward. The leaves are small, of 


\section{FLOWERING SHRUBS}

a dark myrtle-green, revolute at the edges, whitish beneath, unequally distributed along the stem. The deep crimson smooth oval berries are collected by the squaws and sold at a high price in the fall of the year.

There are extensive tracts of low sandy swampy flats in various portions of Canada, covered with a luxuriant growth of low Cranberries. These spots are known as Cranberry Marshes, and are generally overflowed during the spring; many interesting and rare plants are found in these marshes, with mosses and lichens not to be found elsewhere, low evergreens of the Heath family, and some rare plants belonging to the Orchidacex, such as the beautiful Grass Pink (Calopogon pulchellus) and Calypso borealis.

Not only is the fruit of the Low-bush Cranberry in great esteem for tarts and preserves, but it is thought to possess valuable medicinal properties, having been long used in can cerous affections as an outward application. The berries in their uncooked state are acid and powerfully astringent.

There are two species of these low-growing Cranberries found in our peat-bogs and swamps, one larger in all its parts than the other, with the berries paler in colour and of better quality. This is Vaccinium macrocarpon.

This fruit is successfully cultivated for the market in many parts of the Northern States of America, and is said to repay the cost of culture in a very profitable manner.

The Cranberry belongs to one of the sub-orders of the Heath family (Ericacece), nor are its delicate pink-tinted flowers less beautiful than many of the exotic plants of that order, which we rear with care and pains in the greenhouse and conservatory; yet, growing in our midst as it were, few persons that luxuriate in the rich preserve that is made from the ripe fruit have ever seen the elegant trailing-plant, with its graceful blossoms and myrtle-like foliage. 
The botanical name is of Greek origin, from oxus, sour, and coccus, a berry. The plant thrives best in wet sandy soil and low mossy marshes.

\section{Willow-Leaved MEAdowsweET-Spirca alicifolia (L.).}

Frederic Pursh, in his "North American Flora," a valuable work but little referred to, gives no less than seven different species of this Genus Spiræa as natives of Canada, but the description of two or three will be sufficient for the present limited work on the indigenous shrubs of this portion of the Dominion. Of the white-flowered species, Spircea salicifolia, the Willow-leaved Meadowsweet, is the most commonly met with, and is often found in gardens and shrubberies. It is a pretty, graceful shrub, with clustered feathery panicles of white or pale waxy-pink flowers, which are terminal on slender branches; the leaves are long, narrow and thin, of a pale green, serrated on the margins. Our Spiræas will not only bear removal to the garden but will flourish luxuriantly under cultivation. The only objection to their introduction to our borders is that they are apt to become too intrusive.

A very slender form, with simple wand-like stems and terminal spikes of small white flowers, may be found growing among the cracks and fissures of the rocky shores of :Stoney Lake and its numerous islets, rooting in sterile spots among the few wild grasses that find nurture in the scanty mould that is lodged in such crevices. This delicate little shrub may be found in flower all through the hot months of July and August. The Spirras belong to the Rose family. The popular name, Meadowsweet, seems hardly appropriate to our pretty shrub, as it has very little fragrance. But this name for the whole genus is taken from the beautiful and odoriferous British species, Spircea Ulmaria. 
HaRdHACK-Rose-COLOREd SPIRAEA-Spiroa tomentosa (L.).

Of the several pretty shrubs belonging to the Genus Spircea which have been introduced into cultivation, none deserves a place in our gardens more decidedly than the above. It is a beautiful shrub, growing in wild profusion in swamps and on the rocky shores of our small inland lakes. It is about four feet high, with slender wand-like stems that rise from a woody rootstock, clothed with dark green serrated leathery leaves, which are smooth above but very downy underneath. The flowers are of a fine rose-pink, in closely-flowered panicles, a little branching in the larger heads. The bark of the stem is red and covered with down.

While this elegant shrub is chiefly found near water, it seems to prefer gravelly or rocky soil for its habitation.

\section{Purple Scented Raspberry-Rubus odoratus (L.).}

(PLATE XVII.)

In English gardens our beautiful Sweet-scented Raspberry is deemed worthy of a place in the shrubberies, but in its native country it is passed by and regarded as of little worth. Yet what can be more lovely than its rose-shaped blossoms, from the deep purplish-crimson bud, wrapped in its odorous mossy calyx, to the unfolded flower of various shades of deep rose and paler reddish lilac. The flowers derive their pleasant aromatic odor from the closely-set coating of short bristly glandular hairs, each one of which is tipped with a gland of reddish hue containing a sweetscented gum, as in the mossy envelope of the Moss-rose of the garden. These appendages, seen by the aid of a powerful microscope, are objects of exquisite beauty, more admirable than rubies and diamonds, living gems that fill us with wonder while we gaze into their marvellous parts and glorious colors. 


\section{STUDIES OF PLANT LIFE}

All through the hot months of June, July and August a succession of flowers is put forth at the ends of the branches and branchlets of our Sweet-scented Raspberry-

"An odorous chaplet of sweet summer buds."

The shrub is from two to five feet in height, branching from the woody perennial rootstock; the leaves are from three to five-lobed, the lobes pointed and roughly toothed. The leaves are of a dullish green, varying in size from several inches in diameter to mere bracts. The blossoms are often as large as those of the Sweet-briar and Dog-rose, but when first unfolded are more compact and cup-like. The fruit, which is popularly known by the name of Wild Mulberry, consists of many small red grains, somewhat dry and acid, scarcely tempting to the palate but not injurious in any degree. The shrub is more attractive for its flowers than for its insipid fruit. We have, indeed, few that are more ornamental among our native plants than this Rubus. Canada possesses many attractive shrubs that are but little known, which flourish year after year on the lonely shores of our inland lakes and marshy beaver meadows, unnoticed and uncared for in their solitary native haunts.

Closely resembling the Purple Flowering Raspberry is the White Flowering Raspberry ( $R$. Nutkanus-Mocino), the chief difference being in the color of the flowers and the shape of the petals, which in the latter species are of a lovely pure white and oval in shape. The whole plant is slightly smaller and less bristly. The fruit is very similar in both species.

\section{WILD RED RASPBERRY-Rubus strigosus (Michx.).}

The Wild Raspberry springs up spontaneously all over Canada. In the forest, in newly made clearings after the fire has passed over the ground, on every upturned root, 
PI Ait: $x$

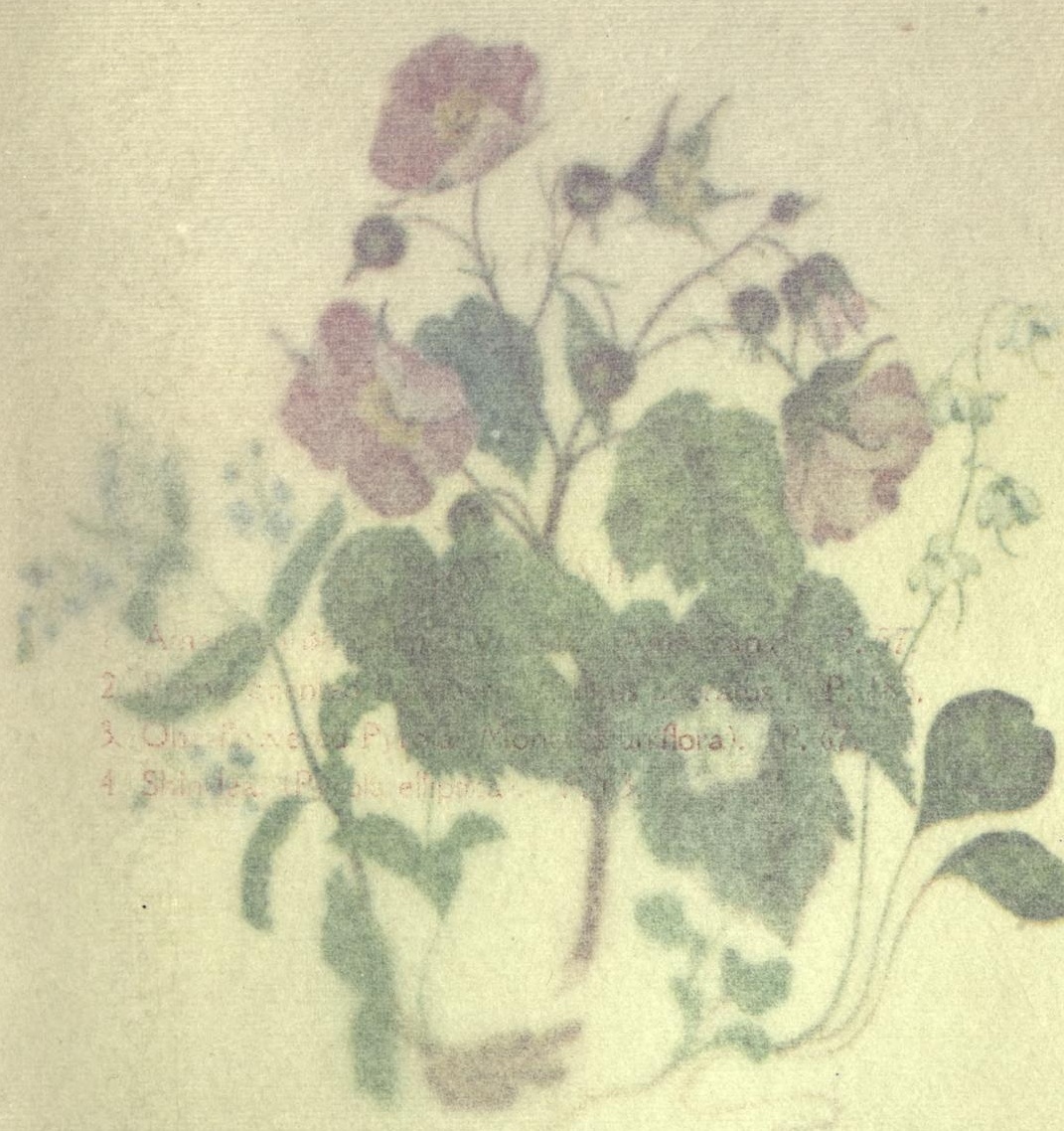




\section{STUDIES OF PLANT PIFE}

All through the hot mosths of June, duiy anis Alguat a succession of Howers is put forth at the endh of the trand hes and branchlets of our Sweet-scented Raspberry-

\section{"An odorous chaplet of sweet summer buds.}

The shrub is from two to five feet in height, brachilita from the woody perennial rootstock; the leaves are frosn three to five-lobed, the lobes pointed and roughly toothed. The leaves are of a dullish green, varying in size from several inches in diameter to mere bracts. The blossoms are often as large as those of the Sweet-briar and Dog-rose, but when first unfolded are more compact and cup-like. The fruit, which is popularly known by the name of Wild Mulberry, consists of many small red grains, somewhat dry and acid, scarcely tempting to the palate bnt not injurious in any degree. The shrub is more attractive for its flowers than for its insipid fruit. We have, indect, few that are more ornamental among onr bative plaves than this trubus. Canada possessas many attruetive shrmbs that are but little known, which thathef givar after your on the lonely shores

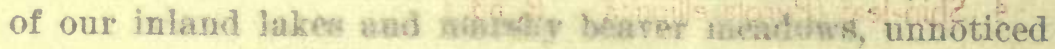
and uncared for in their solnsa sative baxsts.

Closely resenbyling the Puryste Ploweriag Paspherry is the

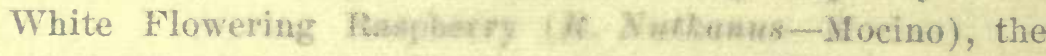
chief difference being in the entor of the flowers and the shape of the petals, which is the latter squeles are of a lovely pure white and oval is stepese the whole plant is slightly smaller and less bristy. The temt is very similar in both species.

WuD ReD Raspteglex-Rubus strigosus (Michx.).

The Wild Raspherry spxings up spontaneously all oves Canada. In the forest, in newly made clearings after the fixe has passed over the ground, on every upturned reat? 


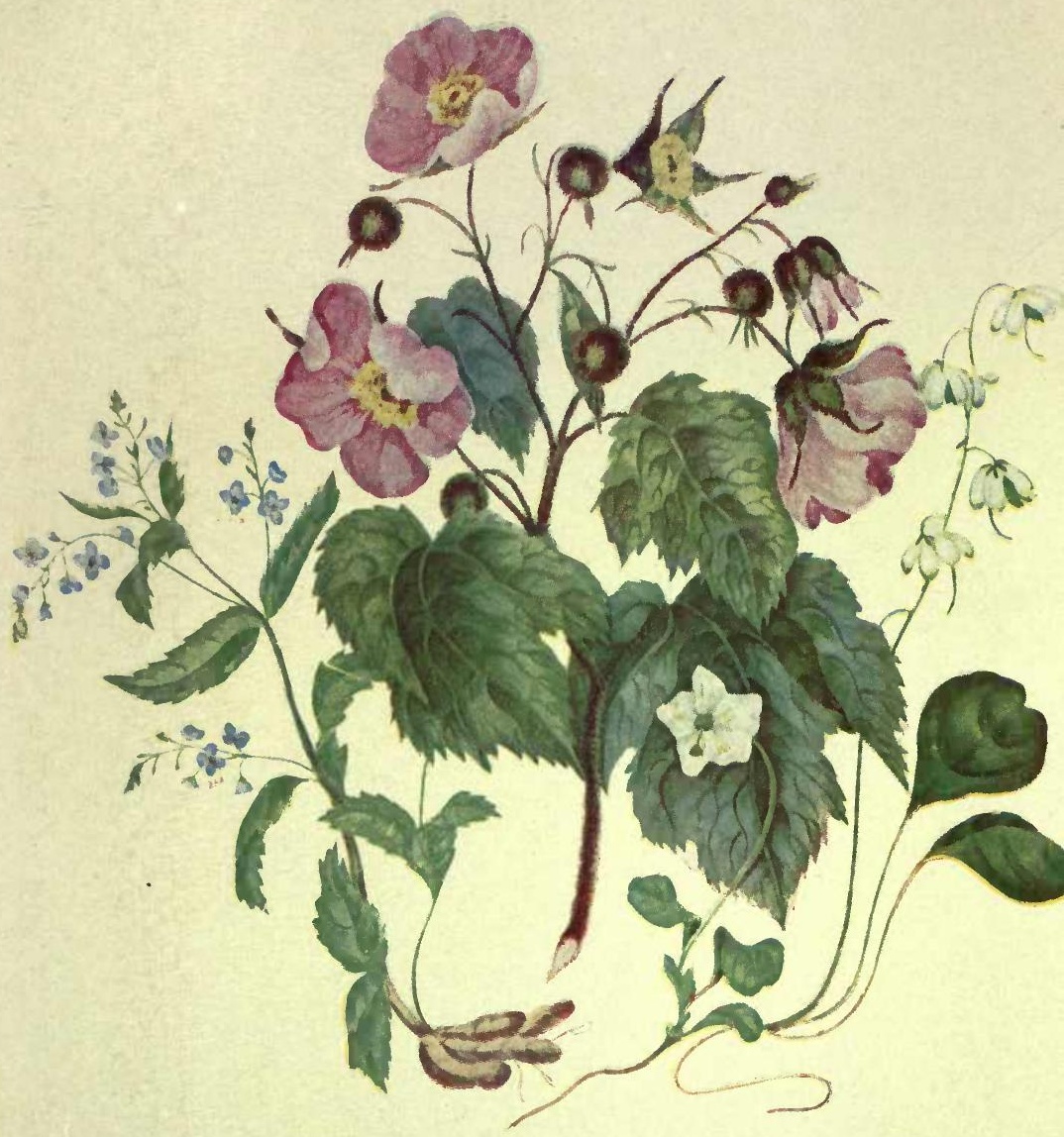





\section{FLOWERING SHRUBS}

in the angles of the snake-fences, and on every waste and neglected spot, the Raspberry appears and takes possession of the land. Truly this useful and palatable fruit proves a blessing and a comfort in various ways to the poor, as well as a wholesome, welcome luxury to the richer inhabitants of our towns and villages. During the fruiting season the women and children are enabled to supply many household wants by the sale of the red and black Raspberries; even the little ones are made to contribute their small mite of labor, and may be seen in large parties going out with tins and sundry small vessels to the Raspberry grounds-wild, rugged spots that have been abandoned by the farmer as worthless for the growth of roots and grain. He does not look beyond and see that with our bountiful Provider there are no waste places. He who fed the wandering multitude with manna in the thirsty desert, and brought forth springs of water from the flinty rock, can give fruits to satisfy the wants of His children in the Canadian wilderness. The wild berries are shared by God's humbler gleaners, the small animals and flocks of birds; and even the insects all come to this table that is spread abroad for them and us; "and something gathers up all fragments and nothing is lost."

The fruit of the common Red Raspberry begins to ripen early in the month of July, just about the time that the Strawberry ceases to be plentiful. The flowers are not very ornamental, whitish, but not clear white, rosaceous in form. The berry ripens very soon after the fading of the flowers.

The color of the fruit of the common Raspberry is of a light red, changing with maturity to a dark crimson. The bush is upright and not very prickly. The leaves have from three to five leaflets, grayish or dull green, wrinkled and veiny, whitish underneath; leaflets serrate, unequally lobed, 
pointed; the fruit is juicy and acid, not as sweet as that of the

\section{BlaCk RASPBERRY-Rubus occidentalis (L.).}

This species is distinguished from the above by its long arching flexile branches, covered with purplish red bark, strongly-hooked prickles and blackish fruit, very rich, firm and sweet. It loves to grow on hilly banks and upturned roots in the shade of the forest, where it can send down its long flexible branches, which bear an abundance of berries long after the Red Raspberry has failed to yield a supply. Gray calls this Black Raspberry by the familiar name of Thimbleberry; but it is a fruit of the Blackberry (Rubus villosus-Ait.) that is commonly known by this name. The berries of the Blackberry are not hollow, nor do they, like the last, separate from the receptacle; they are conical, sweet and luscious to the taste, in quality astringent, but not unpleasantly flavored. The berries ripen in August; the foliage is veiny, coarse, with strong red prickles, the stems strongly armed and covered with a dark-red bark, which with the root is highly astringent and used both in the form of a tea and syrup in cases of dysentery and summer complaint. The fruit in syrup is also considered medicinal and useful in similar complaints.

A very pretty ornamental low creeping shrubby plant is the

Swamp BlackBerRy-Rubus hispidus (L.).

The branches, very strongly armed with hooked prickles, are long and slender, extending two or three feet over the ground; leaves, of three leaflets, bright varnished green, rounded at the ends, more in form like those of the Straw- 


\title{
FLOWERING SHRUBS
}

berry; flowers, rather large, very delicately tinted with pinkish or else white, like a small single Briar Rose. This low Blackberry seems to love rocky ground, creeping among stones and rooting in the black mould in the crevices; the fruit is blackish-purple and pleasant to the taste.

\section{SWAMPBERRY - Rubus triflorus (Richardson),}

is a pretty low trailing plant, bearing somewhat insignificant white flowers and ruby-colored juicy acid fruit; it ripens about the same time as the Wild Strawberry, and the plants are seen running among the wild grasses and strawberry vines, conspicuous by the lighter green leaves, which grow in compounds from three to five, coarsely doubly serrate and sharply pointed; the flowers in small bunches of three. Like that of all the genus, the fruit is perfectly wholesome.

\section{EARLy Wild Rose-Rosa blanda (Ait.).}

\author{
(PLATE XX.)
}

"Nor did I wonder at the lilies white,

Nor praise the deep vermilion of the rose-

"The rose looks fair, but fairer we it deem

For that sweet odor which in it doth live."

-Shakespeare.

The Early Wild Rose (Rosa blanda) is hardly so deeply tinted as our Dwarf Wild Rose (Rosa lucida), but both possess attractions of color and fragrance, qualities that have made the rose the theme of many a poet's song. In the flowery language of the East, beauty and the rose seem almost to be synonymous terms. The Italian poets are full of allusions to this lovely flower, especially to the red Damask Rose. 


\section{STUDIES OF PLANT LIFE}

A popular song in the days of Charles I. was that beginning with the lines-

"Gather your roses while you may,

For time is still a flying,

And that same flower that blooms to-day

To-morrow may be dying."

The leaves of Rosa blanda are pale underneath; leaflets five to seven; flowers blush-pink; stem not very prickly; fruit red and round; the bush from one to three feet in height.

\section{Dwarf Wild Rose-R. lucida (Ehrh.),}

is widely diffused over Canada; it is found on all open plain-lands, but shuns the deep shade of the forest. The bark is of a bright red, and the young wood is armed with bristly prickles of a grayish color. When growing in shade the half-opened flowers and buds are of a deep pink or carmine, but where more exposed in sunny spots the petals fade to a pale blush-color. This shrub becomes somewhat troublesome if encouraged in the garden, owing to the running roots sending up many shoots. In its wild state the Dwarf Rose seldom exceeds three feet in height; it is the second and older wood that bears the flowers; the flowerbearing branches become almost smooth or only remotely thorny. The leaflets vary in number from five to nine; they are sharply serrated at the edges and smooth on the surface; the globular scarlet fruit is flattened at the eye and is of a pleasant sub-acid taste.

This beautiful red-barked rose grows in great profusion on the plains above Rice Lake, clothing large tracts of hill and dale and scenting the evening air at dew-fall with its delicate fragrance. 
The Swamp Rose (Rosa Carolina-L.) is not uncommon; it is often seen growing at the margins of lakes and rivers and at the edges of stony islands; it will climb, with the aid of supporting trees, to the height of eight and ten feet. The numerous and showy flowers are of a somewhat purplish tinge of pink and are borne in corymbs; the leaves are whitish underneath. This rose is armed with stout hooked prickles below, on the old woody stem, but is smoother above; the flowers are more clustered than in the other species.

The Sweet Briar is often found growing in waste places and in thickets near clearings - the seed, no doubt, carried thither by those unconscious husbandmen, the wild birds and the squirrels, that feed upon the heps as they ripen. The leaves retain for some time their sweet fragrance that is so delicious.

There is a delicate pale-flowered Sweet Briar Rose (Rosa micrantha-Smith), having small foliage and numerous blossoms, stems low and branching, and covered with hooked prickles, which has been found growing on the high oak hills in the township of Rawdon, and which, I am informed, is not uncommon in similar localities in Western Canada.

\section{WaxWork-CLIMbing BITTERSWEET-Celastrus} scandens (L.).

This highly ornamental climber, with its clusters of conspicuous berries, is a great adornment to open woods during the late autumnal months, and indeed all through the winter, twining round the stems of slender saplings of white birch, cherry, ash, and elm, not unfrequently clinging so closely to its supporter as to form an intimate union with the bark, its own smooth slender stem, in serpent-like coils, forming graceful volutes round the column of the 


\section{STUDIES OF PLANT LIFE}

unfortunate tree, which suffers from the close embrace that stops the free circulation of the sap in its upward ascent to the branches. The Climbing Bittersweet is a rapid grower, and consequently a bold enemy that takes forcible possession of any young sapling which comes within its reach; a very Old Man of the Sea that, once fixed, no blast of wind can shake off. But while we take the liberty of railing at the unconscious intruder, we must not omit to dwell upon its good qualities. Its brilliant scarlet arils (coverings of the seeds) and orange fruit, that in profusion ornament the tree about which it twines, enliven the dull woods at a season when bright tints have ceased to charm the eye and all the glories of maple, cherry, birch, ash, and beech lie mouldering on the ground at our feet. We may then look upwards to some slender silver-barked birch or gray butternut and admire the gorgeous scarlet festoons that hang so gracefully among the naked leafless branches. The plant, too, is very attractive in its spring verdure. The delicate leaves are ovate-oblong, narrowing towards the point, finely serrated, alternate; the flowers, in raceme-like clusters, are yellowish green, followed by round smooth berry-like pods, which deepen, as the summer advances, from yellow to orange and from orange to bright scarlet. When the seeds are ripe the pod divides and the segments curl back and disclose the three-celled, three-valved berry, which has, in each cell, one or two hard yellow seeds covered with a thin coating of scarlet pulp which is called the aril; this is acrid and burning to the taste. The Indians make use of the acrid juices of this plant, from the inner bark of the root and the bruised berries, to compound an ointment which is stimulant and healing for old sores, chilblains, and disorders of a similar nature. In country places in England I have seen the berries of the Black Bryony boiled down 


\section{FLOWERING SHRUBS}

with lard for an application to chilblains, which had a similar effect to the Indian Bittersweet salve. The Indians also apply this remedy to burns. The inner bark is used as an orange dye by the natives.*

There are several species belonging to this order found in Canada, but though very ornamental in cultivation as shrubs, none are climbing, like our forest Bittersweet, or give such enduring winter ornaments to our houses. Mixed with the branches of spruce, hemlock, and balsam fir, it forms a substitute at Christmas in our churches for the bright glossy leaves and red berries of the English holly.

The Greek name of this ornamental shrub is derived from a word meaning "latter season," on account of the fruit remaining persistent through the winter.

If the Bittersweet were planted in shrubberies, or among trees in plantations, it would become an enduring ornament and enliven the dulness of our Canadian landscape with its bright colors during the long months of winter.

\section{Labrador Tea.-Ledum latifolium (Ait.).}

This is another of our medicinal shrubs, and was held in great repute among the lumbermen and the old backwoodsmen for its sanatory qualities as a strengthener and purifier of the blood, and as being good for the system in various inward complaints. Some of the old settlers used a decoction of the leaves as a substitute for tea, approving of the resinous aromatic flavor. I was induced to try the beverage, but did not find it to my taste, though it was on the whole preferable to hemlock tea, another favorite beverage among backwoodsmen. As a medicine it doubtless deserves the com-

* The name Bittersweet is taken from the graceful English climber Solanum dulcamara (L.), from a fancied resemblance between the two plants. The English Bittersweet is sometimes found in Canada on the borders of swamps and in low woods, but is an introduced plant. 


\section{STUDIES OF PLANT LIFE}

mendations bestowed upon it. Though I did not care for the decoction of the leaves, I was charmed with the beauty of the plant when I first saw it growing on the banks of one of the lakes north of Peterborough. The whole aspect of this remarkable shrub is most interesting. In height it varies from two to four feet; it is bushy in habit, but somewhat open and spreading; the leaves are lanceolate, entire, very decidedly revolute at the margins, and clothed with a dense rust-colored woolly felt beneath. The leaves are of a thick leathery texture and dull brownish-green color. The flowers are white, forming elegant umbel-like clusters at the summits of the slender sprays. As the heads of flowers are very abundant, this shrub forms a striking object when seen growing in numbers along the banks of lakes or in low flats, for it will flourish both on wet and dry situations, nor does it refuse to flower when brought into garden culture. It is a very ornamental object, deserving to be better known than at present seems to be the case. The leaves when bruised emit an agreeable resinous aromatic odor.

The roots of the Labrador Tea are wiry and covered with a bitter astringent bark. Professor Lindley also mentions, in his "Natural System of Botany," the astringent qualities of another member of the family Ledum palustre (L.), a slightly smaller shrub with narrower leaves and oval instead of oblong pods; the stamens, too, are uniformly ten instead of five and seven as in this species. L. palustre is found in the north of Europe and also in the far north in Canada.

\section{WiLd RosemaRY-Andromeda polifolia (L.),}

is another of our native shrubs, and grows in peat bogs and on the swampy margins of lakes, associated with Labrador Tea, the Pitcher Plant and the elegant Low-bush Cranberry. The stems are from three to eighteen inches in height, and 


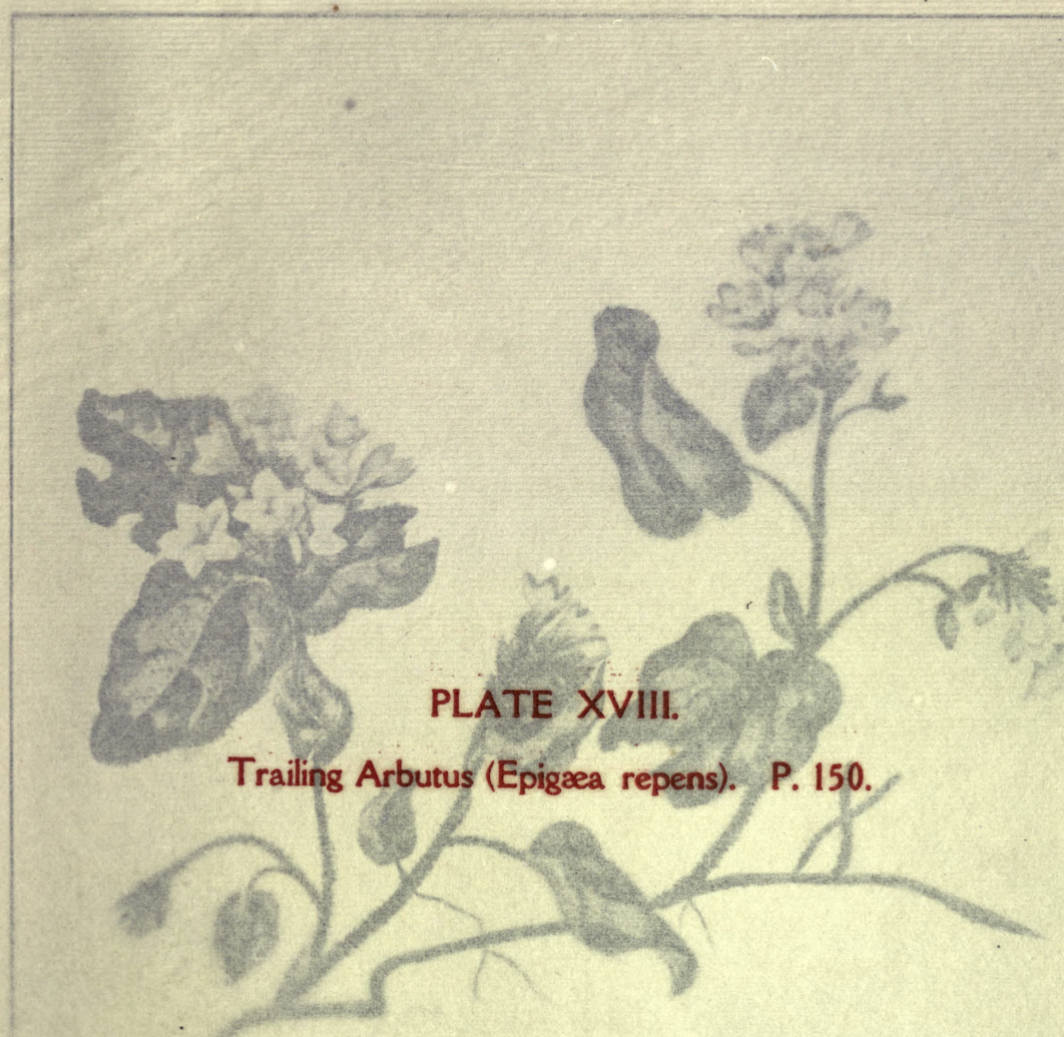


mendations bestowed upon it. Though I did wit care for the decoction of the leaves, I was charmed with die beaty of the plant when I lirat saw it growing on the banks of one of the lakes north of Peterborough. The whole anpect of this remarkable shruh is most interesting. In befikt it varies from two to four feet; it is bushy in labit, but somewhat open aud spreading; the leaves are lanceolate, entire, very decidedly revolute at the margins, and clothed with a dense rust-colored woolly felt beneath. The leaves are of a thick leathery texture and dull brownish-green color. The flowers are white, forming elegant umbel-like clusters at the summits of the slender sprays. As the heads of flowers are very abundant, this shrub forms a striking oinject when seen growing in numbers along the banks of lakes or in low flats, for it will flourish both on wet and dry siluations, nor does it refuse to flower when brought iuto ganden culture. It is a very ornamental objech IIIVX GTAJ9 hather known than at present soerns io (ansagr sssgiq 3 ) zujudiA gnilis T bruised emit an uggree. 021, 9 . (2nsq9r sssgiq3) zujud

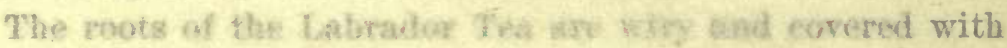

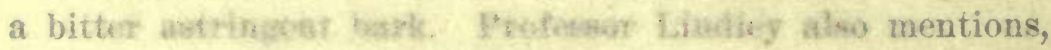
in his "Natural syoters of Botang," the astringent qualities of another mentber of the tabeity fedien palustre (L.), a

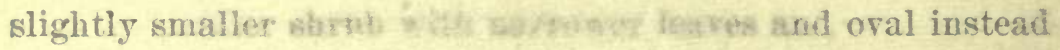

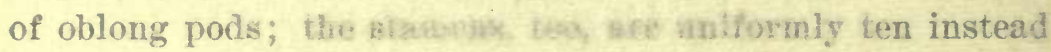
of five and seven as in this spreles. in pelustre is found in the north of Europe and aloo in the far north in Canada.

$$
\text { Wrid Rosemans-indroneda polifolia (L.), }
$$

is another of our native shrubs, and grows in peat bogs and on the swampy margins of lakes, associated with Labrador Tea, the Pitcher Plant and the elegant Low-bush Cranberry. The stems are from three to eighteen inches in height, and 
PLATE XVIII.

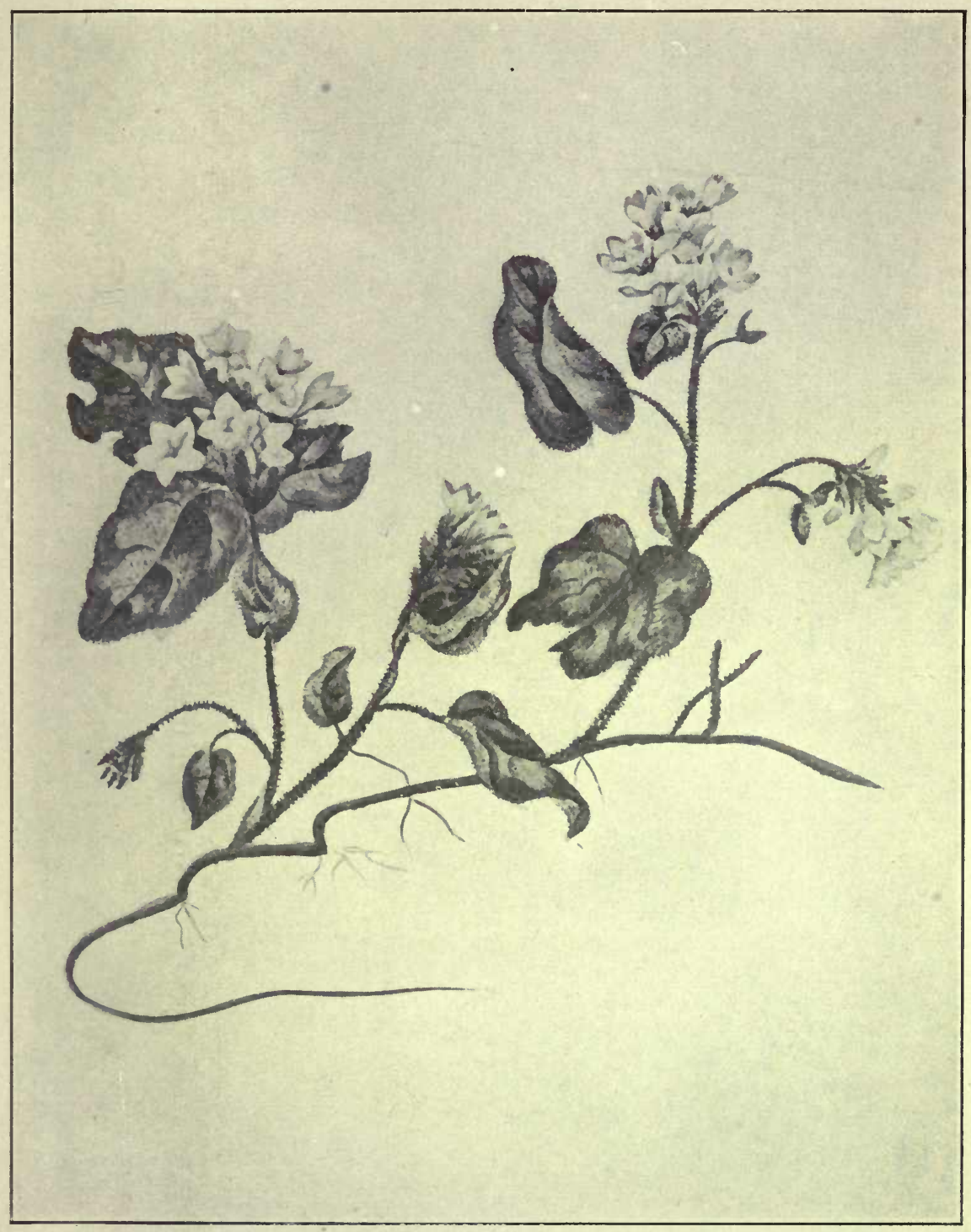





\section{FLOWERING SHRUBS}

bear on the summits of the branches of the previous year the light pinkish flowers, which are three to eight in number, on rather long pedicels and drooping in a onesided raceme; the stamens are ten in number and remain persistent on the dry berry-like capsule. The leaves are shining green above, glaucous-white beneath, and have the margins so strongly revolute as to appear almost linear. This plant is said to have astringent and narcotic properties and to give intoxicating qualities to liquids in which it is infused.

\section{Silky CoRneL-Kinnikinnic-Cornus sericea (L.).}

This species is the true Kinnikinnic of the Indians of central Canada, the leaves and bark being used by them in the place of tobacco, or mixed with it. I have been told it is of an intoxicating quality. The bark is used also as a tonic and febrifuge. The berries are pale blue; the flowers form flat cymes and are greenish-white; the young bark is purplish. The bush grows to the height of eight to ten feet, in low damp rich ground forming dense thickets. There is a fine white silky fibre in the leaves, which may be seen by breaking the mid-rib across. The thread is as fine and as frail as the delicate web with which some spiders envelop their eggs-too fine to be turned to any use.

The silken thread is not confined to this species alone, it exists in many other trees and plants. In the nerves of several of the Dogwoods it is seen quite as conspicuously as in $C$. sericea.

Panicled or Privet-leaved Cornel-Cornus paniculata (L'Her.).

This is a very pretty species of Dogwood found abundantly on the Rice Lake plains, on the high dry hills between the 
hamlets of Harwood and Gore's Landing. The bush is not more than four or five feet high, with light branching sprays. The pretty white flowers are borne in convex cymes, or sometimes in panicles, and are followed by snow-white berries. The foliage is dark-green, often with a purplishbronze tint; the leaves are long and narrow, the nerves whitish, and the light veining distinctly marked; the surface of the leaf is very smooth, but hardly shining. This pretty shrub would be well worthy of being introduced into our shrubberies.

There are many other species of Dogwood which are common to our swamps and thickets, some reaching to the height of small trees, as the Flowering Dogwood, C. florida, which is held in great esteem in the United States for certain medicinal qualities; it has been used as a substitute for Peruvian bark in low fevers. The Indians are said to extract a red dye from the roots. The fruit of the Flowering Dogwood is scarlet; the flowers, with their showy creamywhite involucres, three inches across, are very handsome, and are produced abundantly in the month of June. This very handsome shrub grows in Western Canada, where it sometimes becomes a tree and reaches to the height of twenty or thirty feet. A great contrast is this stately species to the dwarf herbaceous creeping plant of our woods, Cornus Canadensis.

\section{Red Osier Dogwood-Cornus stolonifera (Michx.).}

There are few of the native species of Cornel that are more ornamental than the Red Osier Dogwood, the bright crimson wand-like branches of which, even when stripped of their foliage, are an enduring ornament. Their rosy foliage, mirrored on the surface of the smooth waters of lake or forest stream, enlivens the landscape and delights the eye 


\section{FLOWERING SHRUBS}

when the beauty of the foliage of the surrounding trees and shrubs has been swept away before the autumnal frosts and wintry winds.

In spring and early summer the white fragrant flowers, in crowded flat heads, adorn the low shores. Later in the fall the white berries on the bright red sprays are hardly less attractive. The fruit is unpalatable for man, but is eaten by some of the water-fowl that have their haunts in the lakes and inland waters. This species is the Kinnikinnic of the western and prairie Indians.

\section{Partridgeberry-Trailing Wintergreen-Mitchella repens (L.).}

Another of our pretty red-berried creeping forest plants is the Partridgeberry. The flexile branchlets of this little plant, spreading from the joints of the trailing stem, form a mat of dark green foliage covering unsightly patches of decaying wood, roots, and stones with many a graceful wreath, as if Nature kindly placed them there to veil the rugged ground with grace and beauty, in the same way as the green ivy clothes and adorns the mouldering ruin with its enduring verdure.

Each slender leafy spray of our pretty Wintergreen is terminated by tubular star-shaped twin blossoms, which are divided at the margin into five sharply-pointed segments, white, sometimes slightly tinged with pink. The ovaries are united at the base of the flowers and form one double-eyed round berry for each pair of flowers; the interior of the flower-tube is hairy. The scent is sweet, faintly resembling that of the White Jessamine.

The berries remain persistent all through the winter. They ripen to brilliant scarlet in the autumn and so continue till the return of spring. Thus we may find fresh 
flowers, newly-set fruit and the ripe berries all on the same plant. The small round leaves are veined with white, which gives a variegated look to their dark green surface.

The berries are mealy and insipid but are eaten by the Indian women and children as a dainty. These berries form food for the wood-grouse-our Canadian partridge-and for the woodchuck and other small quadrupeds that have their haunts in our forests and cedar swamps. The elegant wreaths of dark variegated leaves and scarlet berries aré sometimes used by Canadian girls as ornaments for their hair; and I have seen white muslin evening dresses trimmed with the sprays of this pretty evergreen, which had a charming effect, besides showing good taste and economy combined in the fair wearers.

\section{High-bush Cranberry-AMerican Guelder-rose- Viburnum Opulus (L.).}

This fine shrub, with its large loose cymes of white flowers, makes a goodly show during the month of June, mingling its snowy blossoms with the surrounding foliage of dark evergreens on the wooded banks of forest streams and along the low shores of inland lakes and islands. Not less attractive is it when the full bunches of oval berries begin to ripen, first turning to amber, then brilliant orangescarlet, and lastly, when touched by the frosts of autumn, to a transparent crimson. All through the winter you may see the bright ruby fruit upon the bushes, among the snowclad branches, sometimes encased in crystal ice and magnified by the magic touch of hoar-frost. Nor is the fruit of the High-bush Cranberry altogether useless to the Canadian housekeeper; an excellent jelly is often made from the acid juice and pulp of the ripe fruit, when strained from the flat 


\section{FLOWERING SHRUBS}

bony seeds and boiled with sugar; and though somewhat astringent, it forms an excellent sauce for roasted mutton or venison, and, mixed with water, is useful as a fever drink.

As a garden shrub this Viburnum is considered very ornamental, from its abundance of flowers and beautiful fruit. It is no other than the fertile plant of the American Guelderrose. The cultivated Snowball Tree of our gardens is the same species, in which the fertile flowers have been suppressed and the showy sterile ones, which only appear in small numbers round the edge of the cyme in the wild plant, greatly increased in number by the skill of the horticulturist. The $V$. Opulus is also indigenous to England. I remember finding the same flowering bush on the banks of a lonely pond in Reydon Wood, Suffolk, and recognized the Highbush Cranberry on the shores of the Otonabee River from its likeness to the shrub that had attracted my notice in my woodland rambles in England.

The foliage of the High-bush Cranberry takes a bronzedpurple hue, turning to a deep crimson in the Autumn. The leaves are large, three-lobed and pointed. The flowers are borne on wide-spreading peduncled cymes, having the central flowers very small but fertile; the marginal ones are imperfect, being destitute of both stamens and pistils, but the corollas are disproportionately large and give the beauty to the flower clusters of this fine shrub.

The name Cranberry has been improperly applied to Viburnum Opulus, as it has no affinity with the low creeping Marsh Cranberry, that most elegant and charming little plant, with its delicate graceful flowers, myrtle-like leaves, and pear-shaped ruby-colored fruit. Those persons who use the fruit as a preserve know little of the exquisite beauty of the plant itself. To be admired it should be seen in its native haunts, growing among the soft peat-mosses of our 
marshes and bogs. The wreaths of fine dark foliage, bearing the delicate pink waxy flowers on slender thready footstalks, and the large berries in every stage of progressgreen, yellow, deep red and purplish red-resting upon the gray lichens and lovely cream-colored peat-mosses, produce an effect worth seeing.

T'he name of the genus is supposed to be derived from the Latin word vieo, to tie, on account of the flexibility of the branches of some of the species. The word viburna, in the plural, seems to have been applied by the ancients to all plants which were used for tying.

\section{HoBrLe-Bush-Viburnum lantanoides (Michx.).}

This shrub would appear to be typical of the genus, for the branches twine and twist most irregularly; the lower ones are procumbent, often taking root where they touch the ground, whence the popular name. The flowers of this species somewhat resemble the last, but are more creamcolored and appear earlier. The large handsome leaves are round ovate, heart-shaped at the base, and, together with the young branchlets, are covered underneath on the veins and veinlets with tufts of brown down. The ovoid fruit is crimson, turning blackish, and although edible is not very pleasant.

\section{Maple-Leaved Dockmackie-Viburnum acerifolium (L.),}

is a low pretty shrub, not uncommon in open thickets and damp woods. The flowers are more delicate than, and not so conspicuous as, those of the preceding, but it would make a pretty border shrub, bearing some resemblance to the Laurestinus, with which it has been compared; the foliage, however, is very unlike, being of a light-green color, veiny, 


\section{FLOWERING SHRUBS}

and lobed, coarsely-toothed and slightly downy underneath. The fruit is dark purple or black, hard and flat, not edible. There is a larger species which is known as the Larger Dockmackie or Indian Arrow-wood ( $V$. dentatum-L.). The Indians used the long straight wand-like branches of this shrub, when seasoned by the smoke of the wigwam, for the shafts of their arrows; but since they have been able to obtain rifles the flint arrow-heads have fallen into disuse and are found no more in the Indian wigwam. This primitive weapon (formidable it must have been) is found only on old battle-fields, or by chance the settler picks up one in turning the soil on his new burnt fallow, wonders at the curious shaped flint, and perhaps brings it home, but more likely casts it away. It is a type of the uncared-for race whose forefathers shaped the stone with infinite care and pains.

There is another Viburnum,

\section{SheEPBERRY-SWEetberRY-V. Lentago (L.).}

This species is found in rocky ravines and on the sides of dry hills. The fruit is sweet and pleasant, and when cooked, with the addition of red currants, forms a very nice preserve, pudding or pie. As the work of settlement goes on many of our familiar wild shrubs and flowers disappear from their old localities, and in time will be exterminated. Many, too, that might be introduced into cultivated grounds and prove floral ornaments in gardens, or useful for kitchen purposes, are doomed to be lost or utterly neglected.

Is there no wealthy botanist, with ample means to do so, who will form a garden on a large scale and gather together the forest flowers, shrubs and ferns of Canada? It would be a work of great interest. 
ButTon-BUSH-Cephalanthus occidentalis (L.).

A pretty shrub about five feet high, belonging to the Rubiacece or Madder family, with light green smooth leaves, and round heads of closely set whitish-green flowers. The corolla is tubular, slender; style thready and protruding beyond the petals. The flowers have a sweet, faint perfume. This shrub is chiefly found in low thickets on the borders of swamps. The receptable remains persistent on the bush in dry round button-like heads, whence its common name. I am not acquainted with any particular qualities possessed by this shrub. It flowers in August.

\section{Poison Ivy-Poison OAK-Poison Elder-Rhus Toxicodendron (L.).}

The Sumac family boasts of two of the most poisonous vegetables yet known in Canada, viz., Rhus venenata or Poison Sumac, and Rhus Toxicodendron or Poison Ivy. The former, $R$. venenata (DC.), is an elegant shrub, growing in swamps, with shining smooth odd-pinnate leaves, and from ten to fifteen feet high, producing when touched a violent sort of erysipelas, in some cases fatal in its effects. The leaflets, from seven to thirteen, oval, entire, pointed; the flowers, small, insignificant, greenish, in loose panicles from the axils of the upper leaves; berries green, smooth, of the size of peas. This is spoken of as the most deadly of the poisonous sumacs, but fortunately it is of rare occurrence. The common Poison Ivy, however, is only too frequently met with; it grows in low ground or on barren rocky islands, among wild herbs and grasses, in open thickets, at the roots of stumps, and will often find its way into our gardens. It may be found in cultivated fields, flourishing on stone heaps-indeed, wherever its roots can 
PLATE XIX.

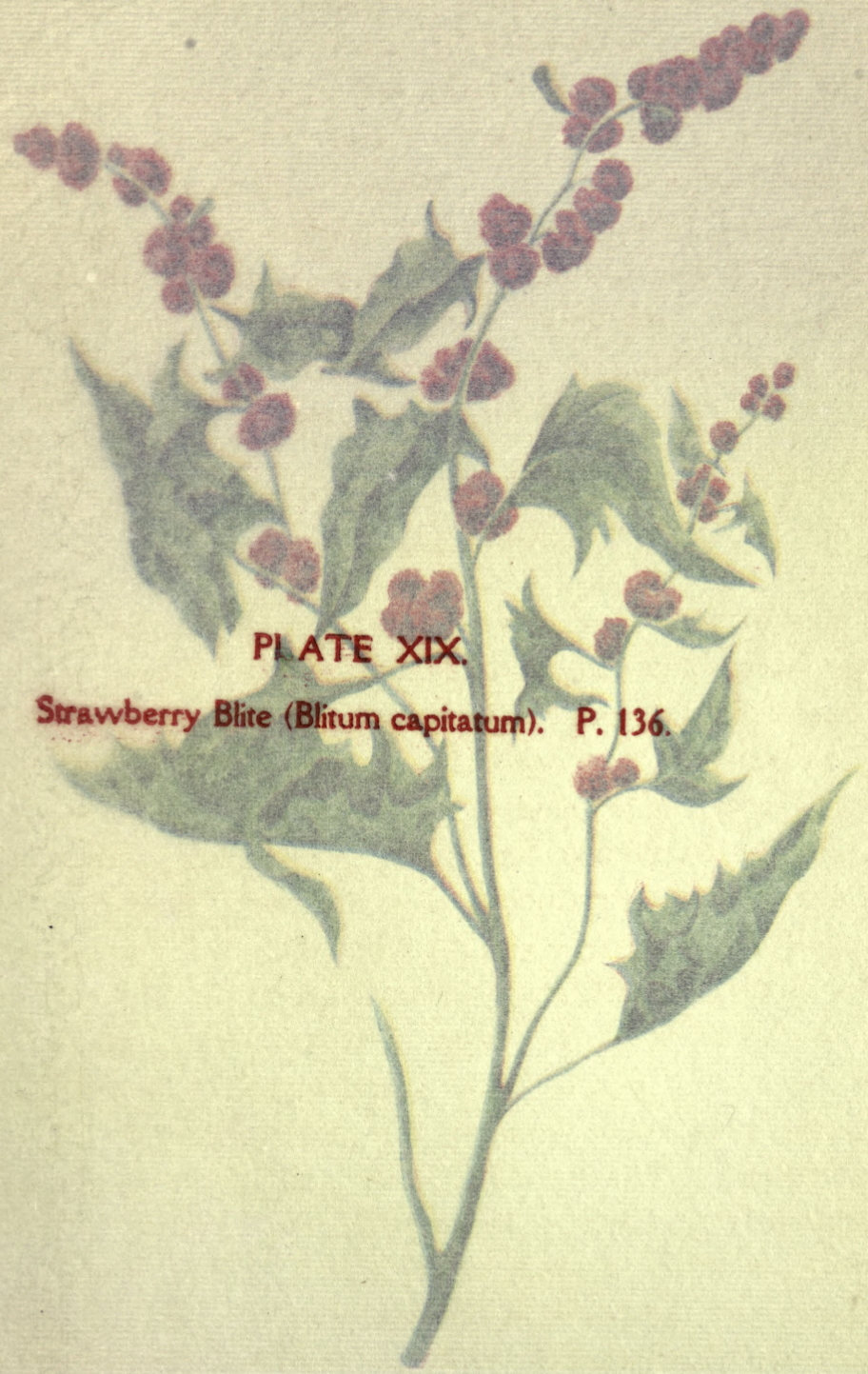




\section{BUTrON-BUSH-Cephalanthus occidentalis (L.).}

A pretty shrub about five feet high, belonging to the Rubiacece or Madder family, with light green smooth leaves, and round heads of closely set whitish-green flowers. The corolla is tubulax, slender: Ntyle thready and protruding beyond the petals. The flowers have a sweet, faint perfume. This shrub is chiefly furat ha low thickets on the borders of swamps. The recoptable muains persistent on the bush in dry round buttonlike beads, whence its common name. I am not acquaisted with asy particular qualities possessed by this shrub. It flewers in August.

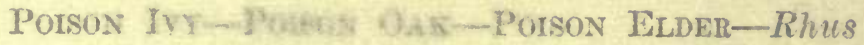 Terivodersulion (1.).}

The Sumac fanite bundasin af cho of the most poisonous vegetables yet knewa la $\mathrm{XIX}$ 3TA 19 mo venenata or Poison buznae, $\partial \varepsilon 1.9$.(musstiqso mutild) sild vanddwave Ivy.

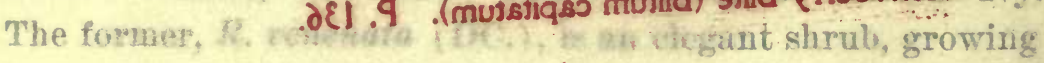
in swamps, with shiniag mowents odd-pinnate leaves, and from ten to fftew fors bish producing when touched a violent sort of ergwigtion is some cases fatal in its effects. The leaflets, from semen th thirteen, owal, entire, pointed; the flowers, smail, insignificant, greeuish, in loose panicles from the axils of the apper leaves; berries green, smoots, of the size of poas. This is spoken of as the most deadiy of the poisonous sumaes, but fortunately it is of rare occurrence. The common Poison Iry, bowever, is only tom frequently met with; it grows in low ground or on barren rocky islands, among wild herbs and grasses, in opess thickets, at the roots of stumps, and will often find its way into cur gardens. It may be found in cultivated fielits, flourishing on stone heaps-indeed, wherever its roots con 
PLATE XIX.

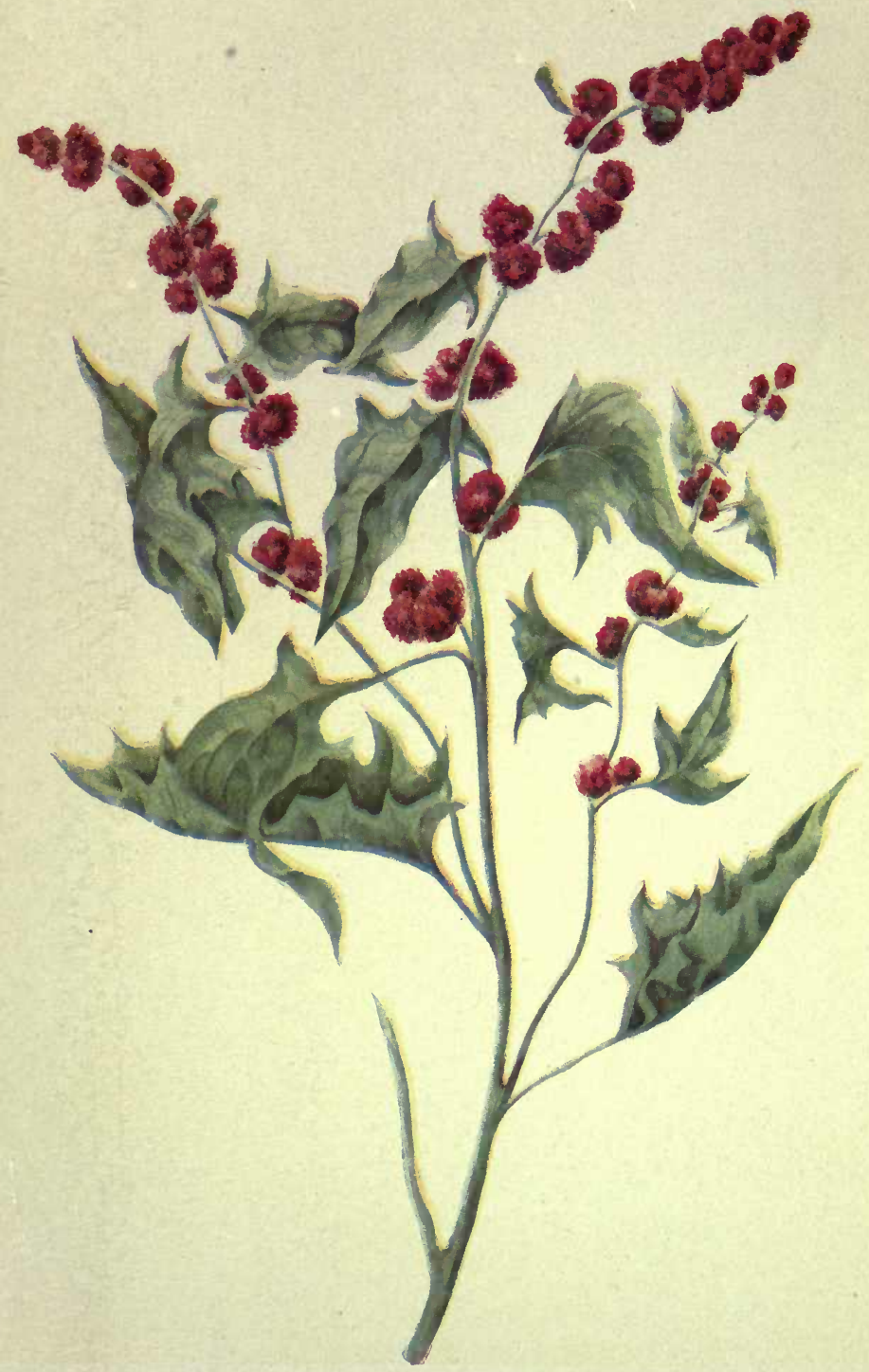





\section{FLOWERING SHRUBS}

find soil to nourish the plant the Poison Ivy may be found. Of its injurious effects on the human body I can speak from experience, having witnessed its baneful influence in many instances. Gray describes its noxious qualities as "poisonous to the touch, even the effluvium in sunshine affecting some persons."

There are various opinions regarding the way in which the virus is communicated, and also in what part of the plant it exists, some persons thinking that actual contact is necessary, others that it is emitted from the leaves when wetted by dews and given out in sunshine; again it is asserted by some to be the pollen of the flowers floating in the air and resting on the skin which is the cause, while others say that the poison is given out in a gaseous vapor at dewfall. All these suggestions may have some foundation. I am inclined to think that the poisonous qualities of the plant are given out in the heat of the day, when the sun's rays are most powerful, and float freely in the atmosphere, as there are instances of persons being affected in daytime when only passing within some little distance of places where the plant abounded, without coming into actual contact with it in any way.

To some persons the Poison Ivy is perfectly harmless. I, for one, have gathered it for my herbarium in all stages of its growth, without receiving from it the slightest injury, while other members of the family have suffered severely from having been near it or walking among the shrubs where it was growing. It is during the hot summer months that most of the cases of poisoning occur, especially in June and July.

The first symptoms are redness about the eyelids, ears, and throat, which quickly increase to angry inflamed blotches, rising in blisters, the whole face becoming swollen so as to 
produce blindness for several hours or days; the irritation of the skin is very great. Sometimes the poison extends over the arms and body and legs; fever, headache and even delirium will affect the patient, as in cases of severe erysipelas. Where the constitution is at all unsound, the effects are worse to overcome, and it is one of the evils induced by the virus that it produces in many cases a chronic disposition to break out, year after year, at the time when the plant is in its most flourishing condition. This has generally taken place in June and July. Some homeopathists are said to treat the case with doses of Rhus Toxicodendron, according to their system; others again use belladonna. Country doctors give alkalies-soda, ammoniaand cooling medicines. The old settlers apply the succulent juicy leaves and stalks of the wild Canadian Balsam (Impatiens fulva) and other cooling herbs.with thick cream; but I should think that limewater, given with milk inwardly and applied outwardly to the skin, as in burns, might prove a good remedy. Where the disease caused by this poisonous plant is so often met with in country places the most ready and certain remedies should be made known to the public. Physicians who have had no experience of the disease produced by the Poison Ivy are sometimes at a loss how to treat it successfully.

Every one should be acquainted with the appearance of the Poison Ivy, so that it may be avoided when out in the country among weeds and thickets, rocks and waters.

This wicked little plant is not without its attractions to the eye; it varies in height from about one foot to two, but will climb, when meeting with support, to ten and fifteen feet.* I have seen it against a stone building, growing along with the Virginia Creeper up to the windows of a lofty

* This is the variety radicans. 


\section{FLOWERING SHRUBS}

second story building, no one having discovered the mischievous intruder, though very different in foliage from the Creeper. The leaves are three-foliate, thin, of a dull palish green, smooth, but not glossy. The leaflets are broad at the base, indented, hardly deep enough to be called lobed, in some instances only a little waved at the margins, pointed, thickened at the junction of the stem. One of the leaflets is generally larger and more lozenge-shaped than the other two, but they vary a good deal in size and form. Sometimes there is a winged lobe on the larger and outer one. Towards evening the leaves droop downwards, exposing less of the surface to the air and night dews.

The plant spreads by means of the roots, which send up shoots from beneath the surface; the stem of the plant is woody, thickening at the joints of the leafstalks. The flowers appear near the tops of the shoots in little upright panicles; they are of a pale greenish-white; the berries ripen in August and are of a dead white, yellow, or duncolored. About the time of the ripening of the berries the leaves begin to droop earthward and turn to beautiful tints of orange, varying to brilliant scarlet, which, with the white fruit, has a pretty effect.

The Rhus contains a black dye which is indelible and which no washing will remove. It is a pity that it cannot be utilized. Professor John Lindley says: "An indelible black dye is produced by the juice extracted from the plant," and adds, "This appears to be a property in common with many plants of this order. The Stagmaria verniciflua furnishes the black lac which is used as a varnish in Japan. The resin produced by this tree causes excoriations and blisters on the skin. The Cashew-nut is another member of the order, all which are more or less remarkable as dye woods, or for some medicinal uses, or acridly poisonous." 
StAG-HORN SuMAC-Rhus typhina (L.).

Though belonging to a very poisonous order of plants, our common native Sumac is more noted for its useful than its hurtful qualities. Both the Dwarf Sumac, $R$. glabra, and the common $R$. typhina are to be found all through Western Canada, in groves and on old neglected clearings, on rocky islets and by roadsides, the seeds being largely sown by the birds that feed upon the berries.

The foliage of the Sumac is very graceful and highly ornamental to the landscape in the fall of the year, when its long drooping pinnate leaves, from nineteen to thirtyone-foliate, assume the most glowing tints of orange, scarlet and crimson. The flowers are of two kinds, or diøcious, in close conical upright heads, terminating the branches; the fruit, small round berries, beset with soft crimson acid hairs, which remain persistent on the receptacle, around which they cluster and give to the tree a strikingly ornamental appearance. These beautiful crimson velvet-like cones continue all through the cold wintry weather, forming a continual feast for the late going and early coming birds-a bountiful provision for those pensioners on God's providence who "neither sow nor reap, and yet our Heavenly Father feedeth them."

The term Stag-horn I imagine to have been suggested not only by the extended branches but also by the fine brown downy covering that clothes the branchlets and stems of the leaves and flower-bearing shoots, resembling the velvety down on the young horns of deer when they first sprout forth.

The wood of the Stag-horn Sumac is of a fine yellow color, and the chips and bark are used as dyewoods. The bark is used in tanning and the root as a powerful astringent and tonic in intermittent fever, while the acid fruit can be 


\section{FLOWERING SHRUBS}

converted into a strong vinegar, and is so used, I am told, in New England. I have, however, never seen the fruit of the Sumac made use of in this country for any household purpose.

\section{Smooth Dwarf SumaC-R. glabra (L.).}

This also is widely diffused through Canada. It is a pretty shrub, but troublesome, from sending up so many shoots; it rises from a very low size to ten and twelve feet high. It is very similar to the last, but the foliage is narrower, glaucous-white underneath; the eleven to thirtyone sharply-toothed and pointed leaflets are very smooth on the surface and take on brilliant orange and scarlet colors before fading. The stem is also smooth and glaucous, like the leaves. There is another dwarf species, $R$. copallina (L.), found in rocky soil, the chief characteristic of which consists in the winged margin of the leafstalks; it is a lower and smaller shrub than $R$. glabra, and is exceedingly rare in Canada.

\section{Black Alder-Winterberry-Ilex verticillata (Gray).}

This red-berried shrub belongs to the Holly family, but we have in Canada no tree which takes the place of the British Hulme or Holly Tree, with its glossy prickle-armed evergreen leaves, green bark, and brilliant garniture of scarlet berries.

\footnotetext{
"It is green in the winter and gay in the spring, And the old holly tree is a beautiful thing."
}

The Holly among the Romans denoted peace and goodwill and possibly for this cause was chosen by the early Christians as symbolical of the peaceable character that should distinguish the followers of the Lord Jesus Christ 
- the Prince of Peace. The earliest notice of decking the churches and dwelling-houses with holly is in the reign of Henry VI., by some pious but now forgotten writer-a chronicler of old customs-who, devoutly lamenting over the disuse of some observances in church matters, consoles himself with the remark that "Our churches and houses are decked with rosemary, holly and ivy, with other goodlye shrubbes that keepe ever green; doubtless to reminde us that the childe then borne was God and man, who shoulde spring uppe as a tender floure to live in oure hartes, and there dwelle for ever more."

Our woody red-berried Winterberry is the nearest relation we have to the Holly in Ontario, but it is not prickly, neither is it an evergreen.

The crest of the Strickland family is the Holly Tree; of the Gordons, the Ivy. This custom of heraldic bearings, especially the crest surmounting the coat of arms, is very ancient, and may be referred back to the time when writing was not in use, when it formed a sort of pictorial history as to the origin of the family. We find it here among Indian tribes, each tribe and the members of it being known by its totem or heraldic sign. Thus we have the "Eagle Tribe," the "Crane," the "Crow," the "Snake," etc., the figure of bird, beast, tree, or reptile being the sign adopted by the heads of the tribe, or chiefs, as the sign manual to be appended to any deed or treaty; scratched or figured with pen, charred stick, or knife, or whatever is the instrument at hand, the totem is rudely drawn, and is the superscription of the tribe.

The individual name is derived from some circumstance independent of the totem of the tribe; whatever object first meets the eye of the child is given as a name. Thus we find "Opechee" (robin), "Omemee" (wild pigeon), "Snow- 
storm," "Red Cloud," "Westwind," "Murmuring Waters," and other poetical names descriptive of natural objects or events.

The Holly is endeared to us by many interesting associations connected with childhood and youth and extending up to extreme old age.

It gladdens the cottage, it brightens the hall, And the gay Holly Tree is beloved by all ; It shadows the altar, it hallows the hearth, An emblem of peaceful and innocent mirth.

Spring blossoms are lovely, and summer flowers gay, But the chill winds will wither and chase them away; While the rude blasts of autumn and winter may rave In vain round the Holly-the Holly so brave.

Though the brave old English gentleman no longer now is seen, And customs old have passed away as things that ne'er have been, Though wassail shout is heard no more, nor Mistletoe we see;

They've left us still the Holly green, the bonny Holly-tree.

There is an old couplet that is common in the north of England about the Holly:

" $O$ the oak, and the ash, and the bonny holly tree, They flourish best of all in the north countrie."

The dark hued evergreen leaves of the Holly, with their rich garniture of vivid scarlet berries, which remain persistent all through the winter and far into the spring, have been so often described or alluded to in print that they must be well known to all. From its use in adorning houses and the churches from Christmastide till Candlemas or the beginning of Lent, the Holly is much thought of and valued by young and old in England; but we miss both the evergreen leaves and the old associations in our Canadian Holly, and so it is less cared for on that account. The bush-for it never rises in this country to any height-is from eight to 
ten feet high; it is mostly found in damp swampy soil or on the banks of streams and beaver meadows, partaking of the habits of the alder, which it resembles in its love of moisture.

The leaves are ovate, somewhat narrowed at the base. serrate at the edges, thin, and not spiny, rather downy underneath; the branches and branchlets are dark colored; flowers greenish, on very short stalks, clustered in the axils of the leaves; the bush stiff and upright; leaves deciduous; berries bright red, remaining on the branches through the winter, much sought for by the wild pigeon and Canadian partridge.

There is another shrub of the same order known as the

\section{Mountain Holly-Nemopanthes Canadensis (DC.),}

which is found northwards in cold bogs. Early in May, the swamps where this shrub abounds have a warm reddishbrown hue from the color of the young leaves; this soon turns to a delicate green, which again changes as it gets mature to a bluish glaucous green. The rose-colored berries are gracefully borne on long pedicels and are sometimes found in great profusion, when they present a beautiful effect. The berries of these hardy shrubs are a great resource for food to the "wee hopping things," our late and early birds, and together with the dry seeds of the Mullein and Rough Amaranth, which harbor many insects in their husky seed-vessels, support them till the spring returns bringing food and gladness to the earth, when the Great Father opens His hand and filleth all things living with plenteousness. 


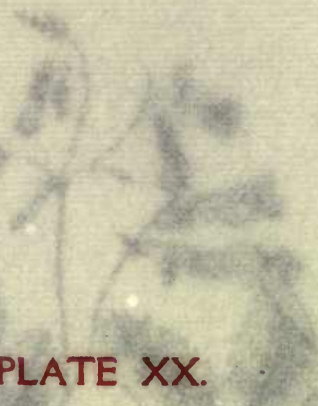

1. Early Wild Rose (Rosa blanda). P. 187.

2. Beard-tongue (Pentstemon pubescens). P. 138.

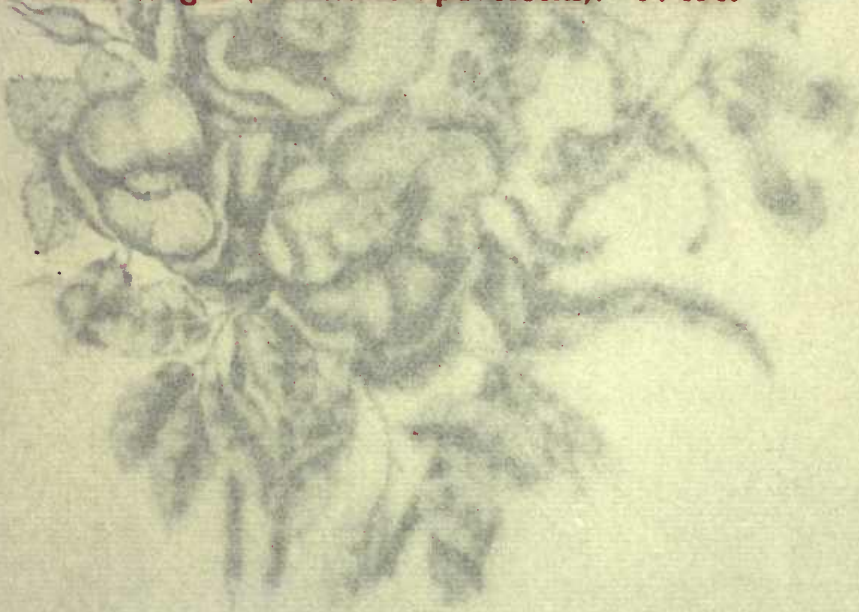


ten feet high; it is mostly found in damp swampy som sf cop the banks of streams and beaver meadows, partaking of ther habits of the alder, which it resembles in its love of mokstents

The leaves are owate, somewhat narrowed at the lesen, serrate at the edges, thin, and not spiny, rather downy underneath; the branches and branchlets are dark colored; flowers greenish, on very short stalks, clustered in the asils of the leaves; the bush stiff and upright; leaves deciduous; berries bright red, remaining on the branches through the winter, much sought for by the wild pigeon and Canadiaiz partridge.

There is another shrub of the same order known as the

Mountarn Holdy-Nemopanthes Canadensis (DC.), XX $\exists T A J 9$

which is found northwards in cold bogs. Early in May, the

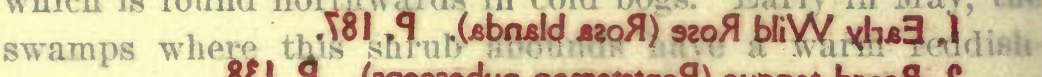

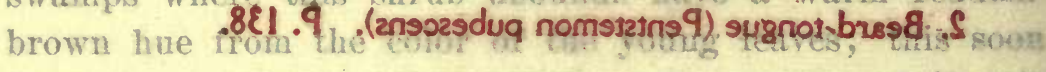
turus to a delieate screet, which again changes as it gets mature to a bitula glansous green. The rosecolored berries are graceftaliy horise ou ling pedicels and are sometimes found in great profukion, when they present a beautifut effect. The berrites of these hardy shrubs are a great resource for food to the "wee hopping things," our late and early birds, and together with the dry seeds of the Mullein and Rongh Amaranth, which harbor many irsecis in their husky seed-ressels, strpport them till the spriag returns bringing food and glatuess to the earth, when the Great Father opens His hand and filleth all things living with plenteousness. 


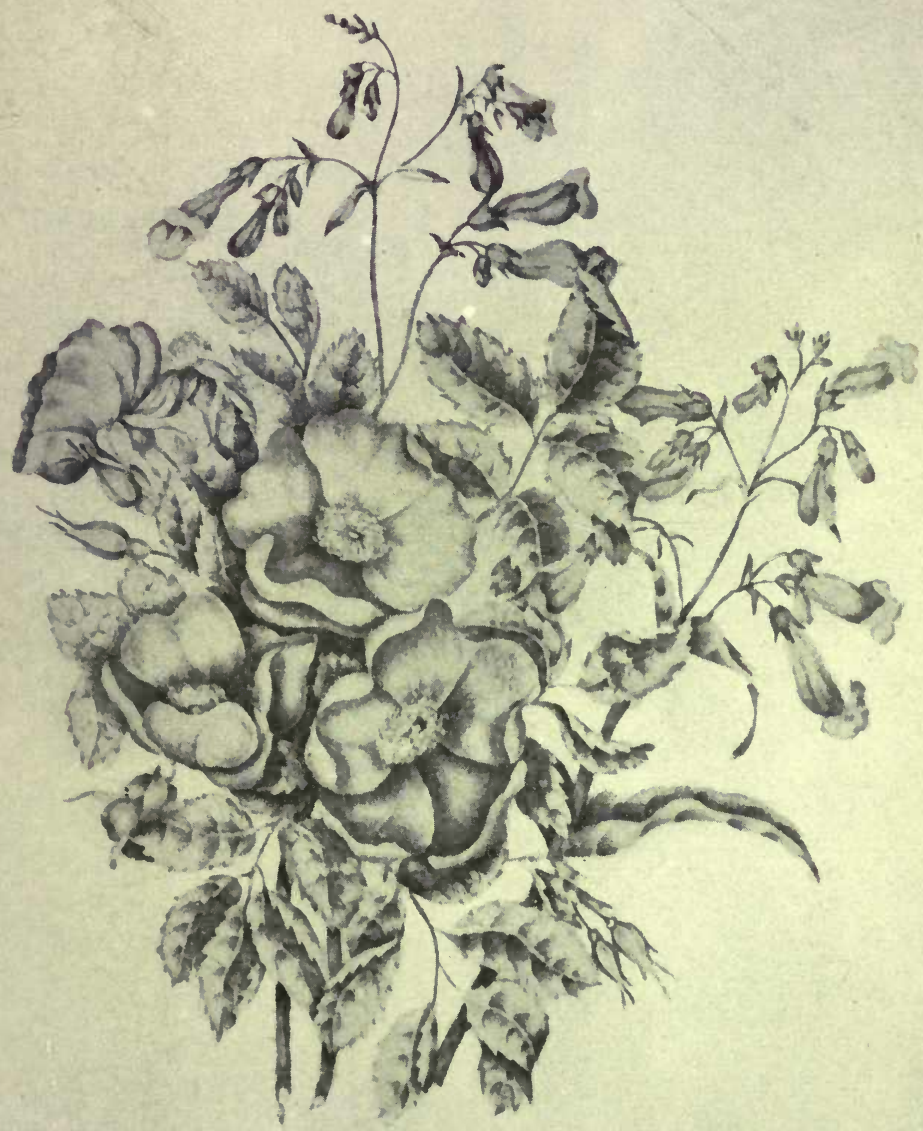





\section{SECTION III.}

\section{GRASSES.}

" And God said, Let the earth bring forth grass, the herb yielding seed. And the earth brought forth grass, and herb yielding seed."

-Gen. i. 11.12.

In drawing this little volume on the native plants to a conclusion, though many have been left unnoticed or unknown by me, I must say a few words respecting the grasses; not, indeed, to add a botanical description of this most beautiful and graceful tribe of plants, which deserves a volume from the pen of one who has given greater attention to the subject, and which seems to me to require the knowledge of a scientific botanist. To do justice to that I must confess I am not competent; any knowledge that I possess is simply that of an observer and a lover of the beautiful works of the Creator.

The student of botany will not be content merely with my superficial, desultory way for acquiring a more intimate acquaintance with the productions of the forest and the field; and to such I would recommend a more particular study of our beautiful native wild grasses, including the rushes and the sedges. At present the field has not been entered upon fully, if even its very borders have been gleaned, unless by that industrious and indefatigable botanist, Professor John Macoun, whom we might well call the Father of Canadian Botany.

But though I cannot venture to treat the subject of the grasses as a botanist, I cannot pass them by without intro- 


\section{STUDIES OF PLANT LIFE}

ducing a few of the lovely, graceful things to the notice of my readers. And if my remarks should prove rather desultory in their range from prairie to forest, and from field to lake or to swampy bank of creek or marsh, I beg my friends to bear with me a little while.

Drooping gracefully in wide branching panicles, we find on our wild plains a soft pale-flowered grass, known by the Indians as Deer-grass, Sorghum nutans (Gray), in the herbage of which the deer found (for it is a thing of the past) both food and shelter. The husk or glumes of this beautiful grass are hairy or minutely silky, which gives a peculiar soft grayish tint to the bending pedicels of the pale spikelets. The culm is from three to four feet high, the leaves hairy at the margins.

Another grass, Andropogon furcatus (Muhl.), more showy but not so graceful, being more upright in its habit of growth, differs very much from the above. This grass is tall, jointed, stiffer in the stem; leaves of a brighter green; heads of flowers spiked, but also branching; glumes of a rich red-brown, made more conspicuous by the bright golden yellow anthers. This grass is also a plain grass, and is known by the same familiar name as the former; the Indians say, "Yes, both deergrass; deer like that, too." It was to increase the growth of this grass that the Indians, at intervals of time, set fire to the Rice Lake plains on the high plateau of land to the eastward, where there was a great feeding ground for the deer and their fawns. For many years this tract of land was covered with oak brush, with only a few old trees that had escaped being injured by the fire. Now, indeed, we have noble oaks of many species, fine branching, well developed trees of white, black, red, scarlet, and overcup oaks, that adorn the plains and form avenues of the concessions and sidelines, most ornamental 


\section{GRASSES}

and grateful to the eye of the traveller. It must have been nearly a century ago since these plains were last burnt over -not within the memory of the oldest settler in the township of Hamilton. Yet deep down, some six or seven feet below the surface, the charred remains of oaks are found to prove the truth of the Indian name, "The Lake of the Burning Plains." Indian names have always some foundation; adopted from peculiar circumstances, they have acquired a sort of historical value among the people.

The name of "Rice Lake" is derived from the fields of Wild Rice, Zizania aquatica (L.), which abound in the shallower waters of this fine inland sheet of water, and give the appearance of low verdant islands clothing its waters. When the Rice is ripened and the leaves faded a golden tint comes over the aquatic field, and the low Rice islands, as they catch the rays of the sun, take the form of sands glowing with yellow light. Where the water is low these Rice beds increase so as nearly to fill the shallow lakes and impede the progress of boats, changing the channel and altering the aspect of the waters.

In the month of June the tender green spikes of the leares begin to appear; in July the Rice begins to push up its stiff, upright stalk, sheathed within the folds of which are the delicate, fragile flowers; from the slender glumes the beautiful straw-colored and purple anthers hang down, fluttering in the breeze which stirs the grassy leaves that float loosely upon the surface of the water, rising and falling with every movement. The plant grows in lakes, ponds, and other waters where the current is not very strong, to the depth of from three to eight feet or even deeper. The grassy or ribbon-like flexible leaves are very long. I remember a gentleman who was rowing me across the lake drew up one at a chance on his oar and measured it, the length being 


\section{STUDIES OF PLANT LIFE}

eleven feet; but with the culm and flower it would have measured twelve or thirteen feet in length.

The month of September or later, in October, is the Indian's Rice harvest. The grain, which is long and narrow and of an olive green or brown tinge, is then ripe. The Indian woman (they do not like to be called squaws since they have become Christians) pushes her light bark canoe or skiff to the edge of the Rice beds, armed not with a sickle, but with a more primitive instrument-a short, thinbladed, somewhat curved wooden paddle, with which she strikes the heads of ripe grain over a stick which she holds in her other hand, directing the strokes so as to let the grain fall to the bottom of the canoe; and thus the Wild Rice crop is reaped to give pleasant, nourishing and satisfying food to her hungry family.

There are many 'ways of preparing dishes of Indian Rice: as an ingredient for savory soups or stews; or with milk, sugar and spices, as puddings; but the most important thing to be observed in cooking the article is steeping the grain-pouring off the water it is steeped in and the first water it is boiled in, which removes any weedy taste from it. It used to be a favorite dish at many tables, but it is more difficult to obtain now.

The grain, when collected, is winnowed in wide baskets from the chaff and weedy matter, parched by a certain process peculiar to the Indians, and stored in mats or rough boxes made from the bark of the birch tree-the Indian's own tree. Formerly we could buy the Indian Rice in any of the grocery stores at $7 \mathrm{~s}$. $6 \mathrm{~d}$. per bushel, but it is much more costly now, as the Indians find it more difficult to obtain. Confined to their villages, they have no longer the resources that formerly helped to maintain them. The birchbark canoe is now a thing of the past; the Wild Rice is now 
only a luxury in their houses; by and by the Indians also will disappear from their $\log$ houses and villages and be known only as a people that were but are not. I am not aware of any other edible grain that is indigenous to Canada. The Foxtail, Setaria viridis (Beauv.), indeed, has hard seeds, but it is utilized only in some places, where it abounds to the farmer's great disgust, as food for his hogs and fowls.

The marsh-growing Redtop or Herd Grass, Agrostis vulgaris (With.), is used as hay. We have many other wild, coarse grasses also that are harvested, and the prairies abound with nutritious plants of this order which are a great resource for the support of the cattle during all seasons. What would become of the settler's beasts in the North-west provinces but for the prairie hay? Very beautiful varieties of the lovely prairie grasses have been gathered by kind friends and sent to me from this "Wild North Land."

One, the cruel Arrow Grass, Stipa spartea (Trin.), is a great nuisance to the settler, the barbed shaft, with curiously twisted awns, piercing hands and feet or insinuating its hard points into the flesh or clothing. The long, twisted arrows of this grass have a curious fashion of winding themselves together, forming a sort of hard rope; the barbed seed lies below, attached to these twisted arrows. There is also on the prairies a wild grass known by the descriptive name of Porcupine Grass; possibly the Arrow Grass may be the same plant with another name. But turning from this uninviting Prairie Pest, as the settlers call it, I would call attention to the useful and sweet-scented Indian Grass, which supplies the poor Indian woman with the material which she weaves into such lovely, tasteful, ornamental baskets, now almost her only resource for materials for her basket-work, by which industry she can earn a small addition to her scanty means of obtaining food 
and clothing. Were it not going beyond the bounds of my subject, I might plead earnestly in behalf of my destitute and too much neglected Indian sisters and dwell upon their wants and trials; but this theme would lead me too far away from my subject. The Indian Grass, so called, Hierochloa borealis (Roem. \& Sch.), is little known in its native state, as it is only the Indians themselves who know where to seek for it. This is among lonely lakes and forest haunts. The soil where it grows is in low sandy flats, especially on shores where the soil is composed of disintegrated, friable rocks, reduced to gritty, coarse sand, where it can push out its slender white running roots most freely; and there it sends up, early in May, its culms and light panicles of shining flowers. The glossy straw-colored plumes and purple anthers make this grass a very lovely object. The leaves, too, are of a shining bright full green. It is the earliest of any of the grasses to push up its pointed blades above the ground; and, so far as my knowledge of the plant goes, for I have had it in my garden for many, many years, it is the earliest to blossom. Only when dried, or rather withered, does it give out its sweet scent, which it retains for years.

I have braided the long ribbon-like leaves and made dinner-mats of them, and also chains tied with colored ribbon, after the Indian fashion, and sent them to friends in the Old Country to lay like lavender in their drawers. One thing I must observe of the Indian Sweet Grass, although it grows readily, and flourishes in any odd corner of the garden in which you plant it, it rarely puts forth a flowering stem; nor can I account for this, unless it may be the absence of some specialty in the native soil that is lacking, and for the need of which it may grow luxuriantly as to leaf but bring no fruit to perfection.

Among the common wild grasses, we have many kinds, 


\section{GRASSES}

known by such expressive names as Redtop, Blue Joint, Herd-grass, Beaver Meadow Grass, Wild Oats, Wild Barley, Foxtail, Squirreltail, Poverty Grass, Cock's-foot, Couch or Spear Grass, Millet, with many others, named or unnamed, that are peculiar to certain localities, in open fields, in the shade of the forest, the thicket, the banks of creeks, in water, or on dry waste lands. There is no spot but has some grass, or rush, or sedge, or reed; they spring up by the water-courses, on the dry parched sands of desert places, and in our path by the wayside; thus we find this lowly herb, under some distinguishing form, wherever we go. Is it not intended as a silent monitor to remind us of the frailty of our earthly being, by bringing back to us the words of the Psalmist: "As for man, his days are as grass; as a flower of the field so he flourisheth : for the wind passeth over it, and it is gone; and the place thereof shall know it no more."-Psalms ciii.

How often in the inspired words do we find similar allusions made to the grass in language alike practical and touching.

"The voice said, Cry! And he said, What shall I cry?

"All flesh is grass, and all the goodliness thereof is as the flower of the field:

"The grass withereth, the flower fadeth; but the word of our God shall stand forever."-Isaiah xl. 6-8.

Thus the grass that we tread beneath our feet, as well as the fairest flower, has alike a significance and a teaching to lead us up to the throne of Him who makes the grandeur of the heavens above and the lowliest plant on earth to speak to us of His goodness, His wisdom and His fatherly care for all. Let me close with the lesson of faith that Christ the Lord himself gave to His disciples: "If God so clothe the grass of the field, . . . . shall He not much more clothe you, O ye of little faith?" 

INDEX 



\section{INDEX}

Actaa alba, 32

Actca spicata, 32

Adder's Tongue, 33; White-flowered, 34 Agrostis vulgaris, 213

Alder, Black, 205

Allium tricoccum, 49

Alum-root, 59

Amaranth, 137; Rough, 208

Amaryllis lutea, 24, 79,

Amelanchier Canadensis, 163

American Brooklime, 57

American Guelder-rose, 196

American Hazelnut, I5I

American Snakeroot; 20

Andromeda polifolia, 192

Andropogon furcatus, 210

Anemone, Wood, 20 et seq.; Tall, 22 ; Crocus, 23

Anemone cylindrica, 22

Anemone dichotoma, 21

Anemone nemorosa, 20

Anemone patens, var Nuttalliana, 23

Anemone Virginiana, 22

Antennaria dipica, III

Antennaria margaritacea, 97, II3

Antennaria neodioica, II2

Antennaria plantaginifolia, II2

Antirrhinuin, 138

Apios tuberosa, 95, 109

Apocynum androsamifolium, Iо

Apocynum cannabinum, 102, 103

Apocynums, 97, I0I, I02

Aquilegia Canadensis, 39

Aracea, 27

Aralia Canadense, 44

Aralia nudicaulis, 92

Aralia quinquefolia, 93

Aralia racemosa, 9I

Aralia trifolia, 93

Arbutus, II7, 150

Arctostaphylos Uva-ursi, II9, 140

Arethusa bulbosa, 105
Arisama Dracontium, 26

Ariscma purpureum, 26

Ariscma triphyllum, 15, I6, 27

Arrow-head, 90, 9I

Arrow-leaved Violet, 4

Arrowroot, 28

Arrow-wood, Indian, 199

Arum, 26; Spotted, 27

Arum maculatum, 27

Arum muironatum, 27

Asclepias Cornuti, 96

Asclepias tuberosa, 95

Asclepiadacea, IOI

Ash, Prickly, I66

Asphodel Lily, 35

Aster, 75, II0, II4, II6, I35

Aster astivus, II5

Aster cordifolius, II5

Aster multiflorus, II5

Aster puniceus, II 5

Balsam, Canadian, 37, 84, 202; Wild, 84

Baneberry, I0, 32; Red, 32

Barley, Wild, 215

Batatas edulis, 89

Beaked Hazelnut, $15 \mathrm{I}$

Bean, Sweet, 95; Wild, 95; Indian, 109

Bearberry, II9, I40, 146

Beard-tongue, 138

Bellflower, Rough-stemmed, 8I

Bellwort, 32

Bergamot, Wild, I30

Betony, Wood, I7

Bindweed, 104

Birthroot, 36

Bishop's Cap, I5

Bittersweet, Climbing, I46, I89 et seq.; English, I9I ; Indian, I9r

Black Alder, 205

Black Hawthorn, I78

Black Raspberry, I80

Blackberry, 97, I86; Swamp, I86 


\section{STUDIES OF PLANT LIFE}

Blazing Star, 134

Blitum Bonus Henricus, I37

Blitum capitatum, $\mathrm{I}_{3} 6$

Blood-root, II, 37

Blue Cohosh, Io, 32

Blueberry, I69; Dwarf, I69; Swamp, 170

Boneset, I23-125

Branching White Wood Violet, 6

Briar Rose, 187

Brooklime, American, 57

Bryony, Black, I9o

Bunchberry, 52

Buttercup, Tall, I3

Butterfly Weed, 95

Button-bush, 200

Button Snakeroot,' r33

Calathian Violet, $142-146$

Calopogon, Grass-pink, 104, I8I

Calopogon pulchellus, 104, I8I

Caltha palustris, 15, 56

Calypso borealis, 105, $18 \mathrm{I}$

Campanula, 66, 82

Campanula Americana, 8I

Campanula aparinoides, 8I

Campanula rotundifolia, 80

Canada Blueberry, i69

Canadian Balsam, 37, 84, 202

Cardinal Flower, 138

Cashew-nut, 203

Cassava, 28

Castilleia coccinea, 40, 41, 64, 68, 138

Castilleia miniata, 4I

Catnip, I30

Caulophyllum thalactroides, to

Ceanothus Americanus, 158

Celandinie, I9

Celastrus scandens, 146,189

Cephalanthus occidentalis, 200

Chamomile, II4

Checkerberry, II7

Cherry, Dwarf, I64; Sand, I64; Wild Black, 166; Wild Red, 166

Chelone glabra, 138

Chenopodium album, 137

Chickweed Wintergreen, 60

Chimaphila umbellata, 67

Chinese Tea Plant, 159

Chiogenes hispidula, 168, 169

Choke-cherry, 165

Chrysanthemum, II4

Circcea alpina, 100

Cistus, 83
Cladonia, 75

Clary, 43

Claytonia Caroliniana, 24 et seq.

Claytonia Virginica, 24 et seq.

Clematis, Wild, 174

Climbing Bittersweet, I46, I89 et seq.

Closed Gentian, I44

Clover, Yellow, 82

Cohosh, Blue, I0, 32; Red, 32; White, 32

Coltsfoot, Yellow, II4

Columbine, Rock, 39,40 ; Wild, 39,40

Common Mullein, I3I

Comptonia asplenifolia, 157-159

Coneflower, II5, I 16

Convolvulus, White Dwarf, I03

Convolvulus spithamceus, 103

Coptis trifolia, 51, 52

Coral-root, 106

Corallorhiza striata, 106

Coreopsis, 116

Cornel, 53, I40; Low, 66; Panicled, 193; Silky, 193

Cornus Canadensis, 52, 194

Cornus circinata, 53

Cornus florida, 53, 194

Cornus paniculata, 193

Cornus sericea, I93

Cormus stolonifera, 194

Corpse Plant, I4I

Corydalis aurea, 3I

Corydalis glauca, 3I

Corylus Americana, I5I

Corylus rostrata, I5I, 152

Cowslip, Water, 15

Cranberry, 74, 180 et seq.; Highbush, 146, 196; Small, 180; Marsh, I80, I97; Low-bush, I8r, 192

Cranesbill, 58, 60

Cratagus coccinea, 179

Cratcegus oxyacantha, 180

Crategus tomentosa, 178

Cream-fruit, IOI

Creeping Spearwort, I4

Crowfoot, I0, I3, III; Water, I4; Yellow Water, 14; White Water. I4

Cuckoo-pint, 29

Currant, I60; Trailing Hairy, 162;

Wild Black, 162 ; Wild Red, $\mathrm{I}_{3}$

Cuscuta Gronovii, 108

Cypripedium, 44 et seq.

Cypripedium acaule, 46

Cypripedium arictinum, 45, 46 


\section{INDEX}

Cypripedium parviflorum, 47

Cypripedium pubescens, $46,47,68$, 80

Cypripedium spectabile, 45

Daffodil, Wood, 32

Damson, I65

Dandelion, II5, I27, I28

Daphne Mezereum, I49

Day-flower, I03

Death-flower, 35 ; White, 36; Red, 36

Dicentra, 30

Dicentra Canadensis, 29

Dicentra cucullaria, 3I

Diervilla trifida, 155

Diplopappus umbellatus, II5

Dirca palustris, 148

Dockmackie, Maple-leaved, I98; Larger, 199

Dodder, Golden, 52, 108

Dogbane, 97, I0I ; Spreading, IOI 194; Red Osier, 194

Dog-rose, 184

Dog-tooth Violet, 33

Dog Violet, 5

Dogwood, 52, 66, 193; Flowering,

Douro Lily, 35

Downy Yellow Violet, 5

Drosera longifolia, 73

Drosera rotundifolia, 73

Dutchman's Breeches, 30

Dwarf Blueberry, I69

Dwarf Cherry, I64

Dwarf Ginseng, 93

Dwarf Wild Rose, I 88

Early Crowfoot, I3

Early-flowering Everlasting, III, II4

Early Everlasting, 19, III, II4

Early White Violet, 2, 3

Early Wild Rose, 187

Easter Flower, 35

Echinacea purpurea, II6

Edelweiss, III

Elder, Black-berried, 152, 157; Redberried, 152; Poison, 152, 200

Eleocharis acicularis, I4

Enchanter's Nightshade, I00

Endive, Wild, 128

Epigea repens, 150

Epilobium angustifolium, 97

Ericacea, 66, 181

Erythronium albidum, 34

Erythronium Americanum, 33
Eupatorium ageratoides, I23, 124

Eupatorium perfoliatum, I23, I24

Eupatorium purpureum, 123

Eupatorium, White, II4

Euphorbia, 28

Evening Primrose, 98

Everlasting, Early, 19, III, II4; White, 97 ; Neglected, II2; Plantain-leaved, II2; Pearly, II3

Eye-bright, 43

False Foxglove, 132

False Honeysuckle, 155

False Mitrewort, I6

False Solomon's Seal, 54

Fern, 157

Feverbush, 149

Filbert, 15I

Fireweed, 97, II 4

Flag, Large Blue, 6r

Flax, Wild, 83 ; Yellow, 83

Fleabane, II4

Fleur-de-Luce, 61,62

Flowering Wintergreen, 17, 18

Fly-flower, 18, 31

Forget-me-not, 57

Fox Grape, I75

Foxglove, False, 132, 133

French Willow, 98

Fringed Gentian, I43, I45

Frost Grape, I73

Frost Plant, 83

Fumitory, 29; Golden, 3I

Galium, 82

Gall of the Earth, I20

Gaultheria procumbens, II7, 169

Garlic, Wild, 49, 50

Gayfeather, I33, I34

Gem-flower, I6

Gentian, Alpine, I42; Dwarf Fringed, I43, I45; Five-flowered, I42, I43, I45; Closed, I44; Soapwort, I42

Gentiana Andrewsii, 143, 144

Gentiana crinita, I43, I45

Gentiana detonsa, I43

Gentiana Pneumonanthe, I43

Gentiana quinquefolia, 145

Gentiana Saponaria, 142, I44

Geranium maculatum, 58

Gerardia, 132, 133, 138; Oak-leaved, I33

Geranium pusillum, 60

Geranium Robertianum, 59 


\section{STUDIES OF PLANT LIFE}

Geranium, Scarlet, 4I ; Wood, 58-60 Gerardia pedicularia, I33

Gerardia purpurea, 132

Gerardia quercifolia, 132, 133

Giant-taper, I3I

Ginger, Wild, 44

Ginseng, 93; Dwarf, 93

Gnaphalium decurrens, II 3

Gnaphalium polycephalum, II2

Gold Thread, 5 I

Goldenrod, 75, 134; Lesser, I0y

Golden Fumitory, 31

Golden Dodder, 52, 108

Good King Henry, I37

Goodyera pubescens, 85

Gooseberry, Wild Smooth, 160;

Prickly, I6r; Small Swamp, I62

Grape, Frost, I73-175; Fox, I75; Isabella, 175

Grass Pink, I04, 18I

Grass, Scorpion, 57; Deer, 210;

Arrow, 213; Foxtail, 213, 215;

Redtop, 2I3, 2I4; Herd, 2I3, 215; Indian, 213, 214; Porcupine, 213; Prairie Pest, 213; Poverty, 215; Cock's-foot, 215; Couch, 215; Speâr, 215; Blue Joint, 215; Beaver Meadow, 215; Squirreltail, 215

Ground Nut, 95

Guelder Rose, American, I96

Habenaria fimbriata, 107

Habenaria viridis, 107

Hairy Yellow-flowered Honeysuckle, I 55

Hairy Woodsia, 75

Hardhack, 75,183

Harebell, 80, 107

Hawkweed, II4

Hawthorn, Black, 178; English, I79

Hazelnut, Beaked, I5I; English Wild, I5I ; American, I5I

Healall, 130

Heath, II7, I69, I8I

Helianthenum Canadense, 83

Helianthus strigosus, 126

Hemp, Indian, IOI, 103

Hepatica, 8 et seq.

Hepatica acutiloba, 8, 9

Hepatica triloba, 8, 9

Heptandria, 60

Herb Robert, 59

Hierochloa borealis, $2 \mathrm{I} 4$

High-bush Cranberry, I46, 196
Hobble-bush, 198

Holly, I9I, 205 et seq.; Mountain, 208

Honeysuckle, 7I, I57; Bush, I53; Fly, I54; False, 155; Hairy Yellow-flowered, 155; Small-flowered, 154; Twin-flowered, 153, I 56

Hooded Violet, 3

Horsemint, 130

Huckleberry, II7, I43, 164, 169

Hulme, 205

Humming-bird Flower, 84

Hyacinth, Wood, 29

Hya-hya, I0I

Ilex verticillata, 146, 205

Impatiens fulva, 84, 202

Impatiens pallida, 84

Indian Arrow-wood, 199

Indian Bean, I09

Indian Bittersweet, I9I

Indian Grass, 213, 214

Indian Hemp, ror, I03

Indian Pipe, I4I

Indian Potato, 95

Indian Strawberry, I36 et seq.

Indian Tobacco, I40

Indian Turnip, 26 et seq.

Iris versicolor, $6 \mathrm{I}, 62$

Ivy, Poison, 84, 152, 200 et seq.

Jack-in-the-Pulpit, 29

Jatropha manihot, 28

Jessamine, White, I95

Jewel Weed, 84

June-berry, 163

Kalmia glauca, 74

Kingcup, I9

Kinnikinnic, 140, 193, I95

Labiatce, 130

Labrador Tea, 74, I59, I9I,

Lady's Bed-straw, 82

Lady's Slipper, 44; Showy, 45; Stemless, 46; Yellow, 47

Lady's Tresses, Slender, 85

Lamb's Quarters, I37

Large Blue Flag, 6I

Lathyrus palustris, 94

Laurel, 150; Spurge, I49

Laurestinus, 198

Leatherwood, I48

Ledum latifolium, 74, 159, I9I 
Ledum palustre, 192

Leek, Wild, 49

Leontopodium alpinum, III

Lesser Snowy Trillium, 36

Lettuce, Wild, II6, I19, I28

Liatris, 127

Liatris cylindracea, 133

Liatris scariosa, I34

Lilium candidum, 78

Lilium Philadelphicum, 78, 79

Lilium pomponium, 79

Lily of the Valley, Wild, 66

Lily, 54, 79, 86 et seq.; Tiger, 30; Tiger, 30; Golden, of Palestine, 79; Wild Orange, 78; Orange, 79,134 ; of the Nile, 89

Lion's-foot, I20

Lindera Benzoin, 149

Linnæa, 66, 69 et seq.

Linncea borealis, 69, 7 I

Linum sulcatum, 83

Liver-Leaf, 8 , ro

Lobelia cardinalis, 138

Lobelia inflata, I40

Lobelia, Red, I38; Blue, I39

Lobelia syphilitica, I39

Lobelia spicata, 140

Long-spurred Violet, 5

Lonicera ciliata, 153

Lonicera hirsuta, 155

Lonicera parviflora, I54

Loose-strife, 107

Lords and Ladies, 29

Lotus, 89

Lousewort, I7

Love-Lies-Bleeding, I37

Lungwort, Blue, 107

Lupine, 48, 68, 104, 134

Lupinus perennis, 68, 80

Madder, 200

Mad-dog Skullcap, 93

Madzaryoum, I49

Mandrake, 55

Maple-leaved Dogmackie, 198

Marigold, Marsh, I5, 56

Marsh Marigold, 15, 56

Marsh Pea, 94

Marsh Speedwell, 57

Marsh Vetchling, 94

Maruta Cotula, 125

May-apple, 55

Mayflower, I50

Mayweed, 125

Meadowsweet, Willow-leaved, I82
Mertensia maritıma, 107

Mezereum, Daphne, I49

Mignonette, Wood, 16

Milktree, Ior

Milkweed, Pink-flowered, 96; Shrubby, IOI

Milkwort, I7; Slender Purple, 20

Millet, 215

Mimulus, 93

Mimulus ringens, 93, 138

Mint, 66, I30; Mountain, 159

Miskodeed, 24

Mitchella ripens, 195

Mitella diphylla, I5

Mitella nuda, I5

Mitrewort, 15; False, 16

Mocassin Flower, 44, 47, 68, 80, 134; Pink-flowered, 45; Hairy, 47;

Lesser-flowered, 47

Monarda fistulosa, I30

Moneses uniflora, 67

Monkey-flower, 93, I 38

Monotropa Hypopitys, I4I

Monotropa uniflora, I4I

Moose-flower, 35

Moosewood, I48

Moostoos Ootasee, I7

Morning Glory, I03, I74

Moss, Lake Erie, 51 ; Sphagnous, 7I ;

Peat, 74; White Peat, 74, 75

Moss Pink, 5I

Mountain Holly, 208

Mouse-root, 79

Mulberry, Wild, I84

Mullein, Common, I3I, 208

Myosotis palustris, 57

Myrica Gale, 74, 158

Myricacea, 157

Nabalus albus, II9

Nabalus altissimus, 120

Narcissus, 79

Nasturtium, 85

Neglected Everlasting, II2

Nelumbium luteum, 89

Nelumbium speciosum, 89

Nemopanthes Canadensis, 208

Nepenthes distillatoria, 77

New Jersey Tea, 158

Nodding Trillium, 35

Nuphar advena, 86, 90

Nuphar Kalmiana, 86

Nuphar lutea, 86

Nymphæa, White, 86

Nymphaa Lotus, 89 


\section{STUDIES OF PLANT LIFE}

Nymphaa odorata, 86,88

Nymphca tuberosa, 86

Oak, Poison, I52, 200

Oats, Wild, 215

Enothera biennis, 98

Enothera pumila, 99

One-flowered Pyrola, 67

One-sided Pyrola, 65

Orange Lily, 79, 134

Orchid, $45,48,76,85$, ro4 et seq.; Fringed Pink, 107; Pearly White, 107

Orchis, 44, 74, I05 et seq.; Ram'shead, 45; Showy, 48; Beautiful, 48; Bird's-foot, I05; Small Round-leaved, 105; Striped, 106; Larger Fringed, I07; Northern Green-man, I07; Pink Fringed, 107; White-fringed, 107

Orchis spectabilis, 48

Osmunda regalis, 75

Oxalis Acetosella, 82

Oxalis stricta, 82

Painted Cup, 40 et seq.

Painted Trillium, 38

Panicled Cornel, I93

Papoose-root, Io, II

Partridgeberry, 195

Pasque-flower, 23

Pea, Marsh, 94

Pear Thorn, I78

Pearly Everlasting, II3

Peat Moss, 74

Pedicularis Canadensis, 17

Pencilled Violet, 4, 5

Pentstemon pubescens, I38

Peppermint, I30

Persicaria, Water, 90, 9I

Phlox, 50

Phlox divaricata, 50, 5I

Pine Sap, I4I

Pink-flowered Moccasin Plant, 45

Pipsissewa, 68

Pitcher Plant, 74, 76, 192

Plantain-leaved Everlasting, II 2

Plantain, Rattlesnake, 85

Platanthera rotundifolia, 105

Plum, 165

Podophyllum peltatum, 55

Poison Elder, 200

Poison Ivy, 84, 152, 200 et seq.

Poison Oak, 200

Poison Sumac, 200
Polygala, 18, 20

Polygala paucifolia, I7, 18

Polygala polygama, 20

Polygala Senega, 18, 20

Polygonatum biflorum, 54

Polygonum amphibium, 91

Polypodium vulgare, 75

Polypody, Rock, 75

Pond-lily, Yellow, 86, 90

Pontederia cordata, 9I

Portland Arrow-root, 28

Portland Sago, 27, 28

Portulaca grandiflora, 129

Portulaca oleracea, 129

Potato, Sweet, 89; Indian, 95

Prenanthes, II4

Prickly Ash, I66

Prickly Gooseberry, r61

Primrose, Evening, 98

Prince's Pine, 67

Privet-leaved Cornel, 193

Prunella vulgaris, 130

Prunus pumila, 164

Prunus Virginiana, 165

Pulse, 68

Purple-scented Raspberry, I83

Purple Trillium, 36

Purslane, 129

Pyrola, One-sided, 65; Roundleaved Lesser, 65; One-flowered, 67; Sweet, 104, 135

Pyrola chlorantha, 66

Pyrola elliptica, 63, 64, 67, 80

Pyrola rotundifolia, 65

Pyrola secunda, 65

Ragroot, II4

Ragwort, II4

Ram's-head Orchis, 45

Ranunculacea, 9, I0, I4

Ranunculus, ro; Alpine, Ir8

Ranunculus acris, I3

Ranunculus aquatilis, I4

Ranunculus fascicularis, 13

Ranunculus multifidus, I4

Ranunculus reptans, I4

Raspberry, I83 et seq.; Wild Red, 97, I84; Purple Scented, I83; White Flowering, I84; Black, I86

Rattlesnake Plantain, 85

Rattlesnake Root, II9

Red-berried Elder, I 52

Red Baneberry, 32

Red Cohosh, 32 
Red Death-flower, 36

Red Osier Dogwood, 194

Redroot, 158

Redtop, 2 I3

Rheumatism Weed, 68

Rhus copallina, 205

Rhus glabra, 204, 205

Rhus Toxicodendron, 152, 200

Rhus typhina, 204

Rhus venenata, 200

Ribes Cynosbati, I6I

Ribes floridum, 162

Ribes lacustre, 162

Ribes oxyacanthoides, 160, I6I

Ribes prostratum, 162

Ribes rubrum, 163

Rice, Wild, 9I, 2II

Rock Columbine, 39, 40

Rock-rose, 83

Rock Saxifrage, III

Rosa blanda, 68, 187, 188

Rosa Carolina, 189

Rosa lucida, I87, 188

Rosa micrantha, 189

Rose-colored Spiræa, I83

Rosemary, Wild, 192, 193

Rose, Wild, 68, 75, 104, 107, 135; Sweet Briar, 184, 189; Damask, 187; Early Wild, I87; Dwarf

Wild, 187, I88; Swamp, I89

Round-leaved Lesser Pyrola, 65

Round-leaved Sundew, 73

Rubus hispidus, 186

Rubus Nutkanus, 184

Rubus occidentalis, 186

Rubus odoratus, $\mathrm{I} 83$

Rubus strigosus, 184

Rubus triflorus, 187

Rubus villosus, 186

Rubiacea, 200

Rudbeckia, IIO, I27

Rudbeckia hirta, II5

\section{Sage, 17, 43}

Sago, Portland, 27, 28

Salvia Sclarea, 43

Sambucus Canadensis, 152

Sambucus pubens, 152

Sand Cherry, 164

Sanguinaria Canadensis, II

Sarracenia purpurea, 74 et seq.

Sarsaparilla, Wild, 92 ; Five-leaved, 93

Sassafras, 150

Satin-flower, I9
Saxifrage, 66; Rock, II I

Scarlet Cup, 40 et seq., 68, I04, I38

Scarlet-fruited Thorn, I79

Scutellaria galericulata, 94

Scutellaria lateriflora, 93

Senega, I7

Serpentaria, I20

Setaria viridis, 213

Shadbush, 163

Shamrock, 82

Sheepberry, I64, 199

Sheep-Laurel, 74

Shin-leaf, 63

Showy Lady's Slipper, 45

Showy Orchis, 48

Side-saddle Flower, 74

Silk-weed, 96

Silky Cornel, I93

Skullcap, Mad-dog, 93; Common, 94

Slender Lady's-tresses, 85

Slender Purple Milkwort, 20

Small Cranberry, I80

Small-flowered Honeysuckle, I54

Small Round-leaved Orchis, I05

Small Swamp Gouseberry, I62

Smiling Wake-robin, 35

Smilacina bifolia, 66

Smooth Dwarf Sumac, 205

Snakehead, I38

Snakeroot, I7; American, 20; White, I24; Button, I33

Snapdragon, I38

Snowball Tree, 197

Snowberry, I56; Creeping, I68

Snowdrop, Wood, I4I

Snow-flower, 8

Soldier's Drinking Cup, 76

Solidago, rog

Solidago gigantea, I35

Solidago latifolia, I34, I35

Solomon's Seal, False, 54

Solanum dulcamara, I9I

Sorghum nutans, 210

Sow-thistle, II 5

Spatter Dock, 90

Spearmint, I30

Spearwort, Creeping, I4

Speckled Jewel, 84

Speedwell, 57 ; Marsh, 57 ; Water, 57

Sphagnum cymbifolium, 74

Spice Wintergreen, II7

Spicebush, I49

Spignet-root, 92

Spikenard, 9I

Spinach, 136 


\section{STUDIES OF PLANT LIFE}

Spiræa, Rose-colored, 183

Spirca salicifolia, 75, I82

Spiraa tomentosa, 75, 183

Spirca Ulmaria, 182

Spiranthes gracilis, 85

Spreading Dogbane, Ior

Spring Beauty, 24

Spurge Laurel, I49

Squaw-berry, 52

Squirrel Corn, 29 et seq.

Squirreltail, 215

Stag-horn Sumac, 204

Stagmaria verniciflua, 203

Starflower, 60

Stemless Lady's Slipper, 46

Stipa spartea, 213

Strawberry Blite, I36

Strawberry, Wild, I9; Barren Wild, III ; Indian, 136 et seq.

Streptopus roseus, 54

Strychnia, Ior

Sumac, Poison, 200; Stag-horn, 204; Smooth Dwarf, 205

Sundew, Round-leaved, 73

Sunflower, I10, II5, I16, I26, I27 ; Wild, 126

Swampberry, 187

Swamp Blackberry, I86

Swamp Blueberry, I70

Sweetberry, I99

Sweet Briar, 184, I89

Sweet-fern, 157, I59

Sweet-Gale, 74, I57, 158

Sweet Potato, 89

Sweet-scented Water Lily, 86

Sweet Wintergreen, 63

Symphoricarpus racemosus, 156

Tall Buttercup, I3

Tansy, II6

Tapegrass, 89

Tapioca, 29

Taraxacum Dens-leonis, 127

Teaberry, II7, I69

Tea, New Jersey, 158

Tea Plant, Chinese, I59

Thimb!eberry, 186

Thimble-weed, 22

Thistle, II4

Thorn, Pear, 178; Scarlet-fruited, I79; English White, I80

Thornberry, I6I

Thoroughwort, 121, I23, 125

Tiarella cordifolia, 16

Tiger Lily, 30
Tobacco, Indian, 140

Touch-me-not, 84

Trailing Arbutus, I50

Trailing Hairy Currant, I62

Trailing Wintergreen, I95

Trientalis Americana, 60

Trillium, 35 et seq., 134; Nodding, 35; White, 35, 36, 48; Lesser Snowy, 36; Purple, 36; Red, 37 ; Painted, 38

Trillium cernuum, 35

Trillium erectum, 36

Trillium erythrocarpum, 38

Trillium grandiflorum, $35,36,68$

Trillium nivale, 36

Turnip, Indian, 26 et seq.

Turtlehead, I38

Tussilago Farfara, II4

Twinflower, 69, I 57

Twin-flowered Honeysuckle, 153,156

Twisted Stalk, 54

Uvularia grandiflora, 32

Uvularia perfoliata, 33

Uvularia sessilifolia, 33

Vaccinium Canadense, 169

Vaccinium corymbosum, 169, 170

Vaccinium macrocarpon, I8I

Vaccinium Oxycoccus, 180

Vaccinium Pennsylvanicum, 169

Vallisneria spiralis, 89

Verbascum Thapsus, I3I

Veronica, 57

Veronica Americana, 57

Vetch, 107

Vetchling, Marsh, 94

Viburnum acerifolium, 198

Viburnum lantanoides, 198

Viburnum Lentago, 164, 199

Viburnum Opulus, 146, 196, 197

Viola blanda, 2, 5

Viola Canadensis, 6

Viola canina, 5

Viola clandestina, 3

Viola cucullata, 3. III

Viola Dicksoni, 3

Viola odorata, 2

Viola ovata, 4

Viola prionosepala, 4

Viola pubescens, 5

Viola renifolia, 4

Viola rostrata, 5

Viola sagittata, 4

Viola subviscosa, 4 


\section{INDEX}

Violet, I et seq.; Early White, 2, 3; Hooded, 3; Wood, 3; Arrowleaved, 4; Pencilled, 4, 5; Long Spurred 5; Dog, 5 ; Downy Yellow, 5 ; Canada, 6 ; Branching White Wood, 6; Dog-tooth, 33; Blue, III

Virburnum dentatum, 199

Virginia Creeper, 202

Vitis cordifolia, I73

Vitis Labrusca, I75

Vitis riparia, 173

Wake-robin, Smiling, 35

Waldsteinia fragarioides, III

Water-Lily, Sweet-scented, White, 86, 90; Yellow, 89

Water Persicaria, 90, 9I

Water Speedwell, 57

Waxwork, 189

White Cohosh, 32

White Death-flower, 36

White Dwarf Convolvulus, I03

White-flowered Adder's-tongue, 34

White Snakeroot, I24

White Trillium, $35,36,48$

White Water Crowfoot, I4

Wild Bean, 95

Wild Bergamot, I30

Wild Black Currant, 162

Wild Columbine, 39,40

Wild Flax, 83

Wild Garlic, 49

Wild Ginger, 44

Wild Leek, 49

Wild Orange Lily, 78, 134

Wild Red Currant, 163

Wild Red Raspberry, 97, I84

Wild Rice, 9I, 2II
Wild Rosemary, 192, 193

Wild Smooth Gooseberry, 160

Wild Strawberry, 19, II I, 136 et seq.

Wild Sunflower, 126

Willow-herb, 97

Willow-leaved Meadowsweet, 182

Wind Flower, 8, 2I

Winterberry, I46, 205

Wintergreen, I7, 68, 80, I30, 140; Flowering, 17, 18; Chickweed, 60; Sweet, 63; Spice, 117; Aromatic, II7, I69; Box-leaved, II8; Trailing, 195

Wood Anemone, 20 et seq.

Wood Betony, I7

86; Woodbine, 153

Wood Daffodil, 32

Wood Geranium, 58-60

Wood Hyacinth, 29

Wood Mignonette, I6

Wood Snowdrop, I4I

Wood Violet, 3

Woodsia, Hairy, 75

Woodsia Ilvensis, 75

Wood-sorrel, 82; Yellow-flowered, 82

Wycopy, 149

Xanthoxylum Americanum, 166

Yellow Coltsfoot, II4

Yellow Flax, 83

Yellow-flowered Wood Sorrel, 82

Yellow Lady's Slipper, 47

Yellow Pond Lily, 86, 90

Yellow Water Crowfoot, I4

Yellowwood, 167

Zizania aquatica, 91, 21 I 





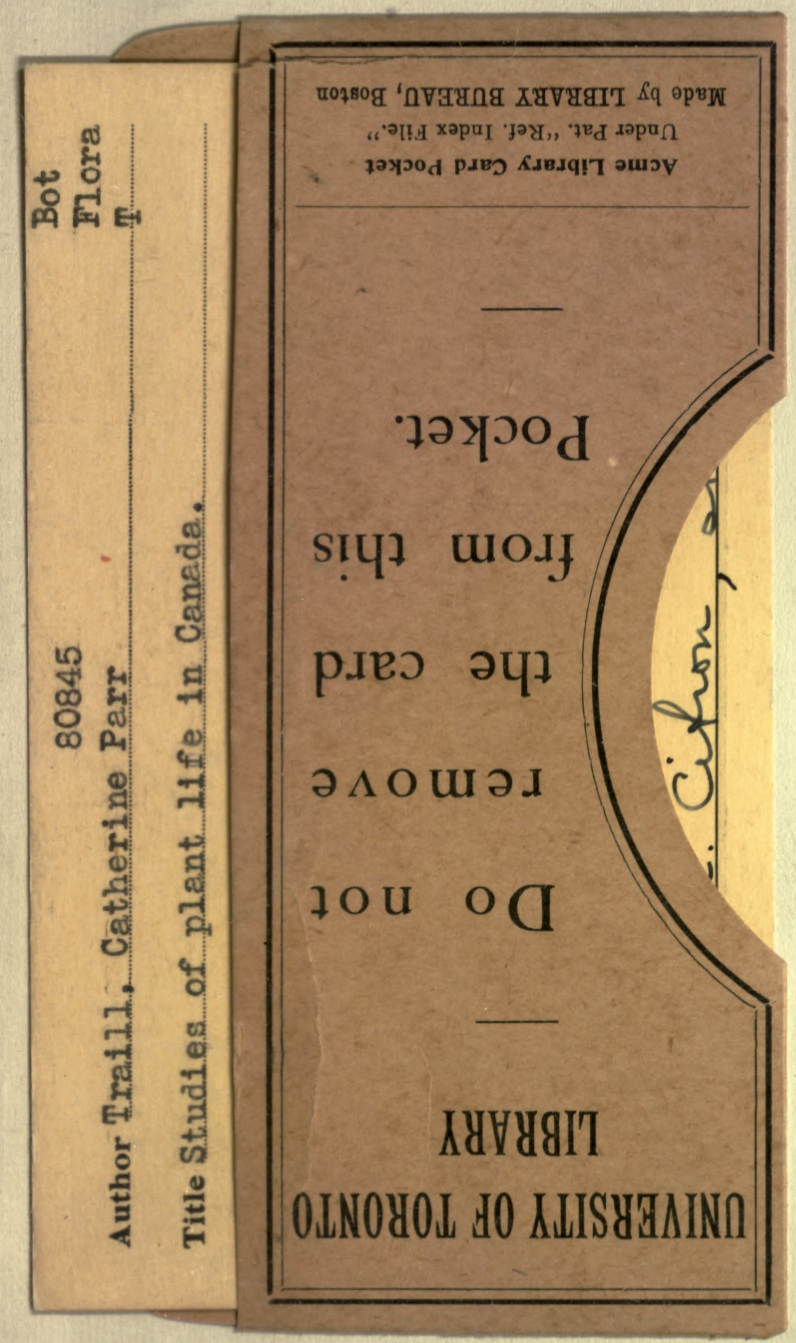


